LEANDRO GUIMARÃES BAIS MARTINS

\title{
Avaliação do potencial de aplicação de técnicas compensatórias em áreas urbanas consolidadas
}

Tese apresentada à Escola de Engenharia de São Carlos, da Universidade de São Paulo, como parte dos requisitos para a obtenção do título de Doutor em Ciências: Engenharia Hidráulica e Saneamento.

Orientador: Prof. Dr. João Luiz Boccia Brandão

VERSÃO CORRIGIDA

São Carlos 
AUTORIZO A REPRODUÇÃo TOTAL OU PARCIAL DESTE TRABALHO, POR QUALQUER MEIO CONVENCIONAL OU ELETRÔNICO, PARA FINS DE ESTUDO E PESQUISA, DESDE QUE CITADA A FONTE.

Martins, Leandro Guimarães Bais

M379a

Avaliação do potencial de aplicação de técnicas compensatórias em áreas urbanas consolidadas / Leandro

Guimarães Bais Martins; Orientador João Luiz Boccia Brandão. São Carlos, SP.

Tese (Doutorado) - Programa de Pós-Graduação em Engenharia Hidráulica e Saneamento e Área de

Concentração em Hidráulica e Saneamento -- Escola de Engenharia de São Carlos da Universidade de São Paulo, São Carlos - SP.

1. Urbanização. 2. SWMM. 3. Simulação hidrológica. 4. Inundações. I. Título. 


\section{FOLHA DE JULGAMENTO}

\section{Candidato: LEANDRO GUIMARĀES BAIS MARTINS}

Título da tese: "Avaliação do potencial de aplicação de técnicas compensatórias em áreas urbanas consolidadas"

Data da defesa: 10.02.2017

Comissão Julgadora:

Resultado:

Prof. Titular Edson Cezar Wendland (Orienfador)

(Escola de Engenharia de São Carlos/EESC)

Prof. Dr. Eduardo Mario Mendiondo

(Escola de Engenharia de São Carlos/EESC)

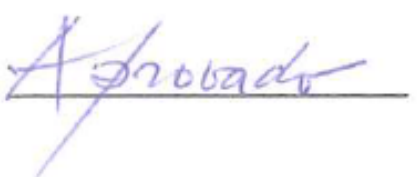

Aprovado

Prof. Dr. Ademir Paceli Barbosa

(Universidade Federal de São Carlos/UFSCar-São Carlos)

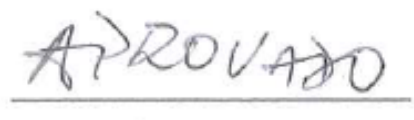

Prof. Dr. Jefferson Nascimento de Oliveira

(Universidade Estadual Paulista "Júlio de Mesquita Filho"/UNESP)

Prof. Dr. Nilo de Oliveira Nascimento

(Universidade Federal de Minas Gerais/UFMG)

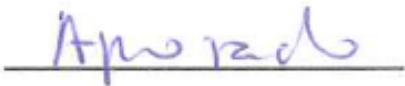

Coordenadora do Programa de Pós-Graduação em Engenharia Hidráulica e Saneamento:

Profa. Associada Maria Bernadete A. Varesche Silva

Presidente da Comissão de Pós-Graduação:

Prof. Associado Luis Fernando Costa Alberto 


\section{DedicatóRIA}

Ao professor João Luiz Boccia Brandão (1957-2016), em memória. 


\section{AGRADECIMENTOS}

Gostaria de agradecer primeiramente ao professor João Luiz Boccia Brandão, meu orientador e amigo, pelos valiosos ensinamentos ao longo destes quatro anos. Poucas são as pessoas com suas qualidades profissionais e pessoais. Agradeço imensamente sua confiança na minha capacidade de realizar o trabalho, mas agradeço principalmente por nunca ter duvidado de mim nos quatro períodos mais críticos destes anos: o nascimento do meu primeiro filho, Caio; o início da minha carreira de docente; o nascimento do meu segundo filho, Joaquim e; minha volta à cidade de Campo Grande antes do fim de meu doutorado. Brandão sempre reagiu com calma a estas notícias "bomba", mesmo eu achando que me enforcar era um direito dele. Sempre foi calmo, atencioso, amigo e profissional, até nossa última conversa. Por tudo isso, agradeço a ele.

Agradeço ao pessoal da USP, profissionais e amigos, que fizeram parte na minha vida em São Carlos. Agradeço à Sá, Pavi, Pri, Rose, Fernanda e Flávia. Aos técnicos Roberto Bérgamo e Marcelo Miky, ambos colegas de aventuras em campo e amigos a serem levados para toda a vida. Aos um dia meus professores e hoje amigos Edson Wendland, Rodrigo Porto, Mario Mendiondo e Luisa Fernanda.

Agradeço a todos os amigos que fiz durante meu tempo em São Carlos. São muitos e verdadeiros. Em especial àqueles que se tornaram parte de minha família, apadrinhando meu casamento e meus filhos.

Agradeço à cidade de São Carlos, que me acolheu tão bem durante estes seis anos. Terra natal de meus dois filhos, segunda casa de minha família.

Agradeço à minha família, em especial aos meus pais, pelo apoio incondicional às minhas escolhas, desde minha escolha pela área acadêmica até a decisão de iniciar a minha família longe de casa e no meio de um trabalho tão importante.

Agradeço imensamente à Marjolly, minha esposa e professora preferida, pelos maravilhosos anos que vivemos até aqui e pelos outros tantos que virão, agora junto de nossos filhos Caio e Joaquim, nascidos durante a realização deste trabalho. A estes devo tudo. 
Agradeço à CAPES e ao programa MAPLU 2 pelo apoio financeiro para a execução deste trabalho e de outros trabalhos de pesquisa relacionados ao grupo de pesquisas do LABSIN.

A todos estes, o meu muito obrigado. 


\section{RESUMO}

MARTINS, L. G. B. Avaliação do potencial de aplicação de técnicas compensatórias em áreas urbanas consolidadas. 2017. 197f. Tese (Doutorado) - Escola de Engenharia de São Carlos, Universidade de São Paulo, São Carlos, 2017.

O desenvolvimento urbano altera significativamente o ciclo natural das bacias hidrográficas. Com o surgimento da drenagem urbana sustentável, o rápido escoamento das águas pluviais deu lugar à restituição das características naturais da bacia hidrográfica através do planejamento do desenvolvimento urbano aliado ao uso de técnicas compensatórias que promovem a infiltração e detenção de águas pluviais. Entretanto, em bacias urbanizadas, o uso das técnicas compensatórias tem alcance limitado, principalmente pelo alto grau de impermeabilização das bacias, pela falta de preocupação com a drenagem durante a expansão urbana, pela baixa disponibilidade de espaço e pelos altos custos de aplicação de medidas estruturais de drenagem urbana. Assim, os princípios de drenagem urbana sustentável são muitas vezes considerados inadequados a ambientes de urbanização consolidada. Desta forma, este trabalho teve por objetivo avaliar o desempenho do uso em conjunto de diversas técnicas compensatórias definidas através do desenvolvimento de mapas de adequabilidade de uma bacia hidrográfica urbana à aplicação das técnicas compensatórias e de simulação hidrológica. Foram avaliadas bacias de detenção, pavimentos permeáveis, jardins de chuva, telhados verdes, trincheiras de infiltração e microreservatórios individuais. O desempenho das técnicas compensatórias foi avaliado individualmente e trabalhando em conjunto. Mapas de adequabilidade foram criados para locação e quantificação das técnicas compensatórias na bacia hidrográfica. Os resultados mostraram que a aplicação extensiva de técnicas compensatórias em ambiente urbano pode provocar melhoras significativas na redução de vazão de pico e controle do volume de hidrogramas de cheia, com melhores desempenhos individuais de até 35,5\% de redução de pico e $32,48 \%$ de redução de volume de hidrogramas (TR 2 anos) com o uso de trincheiras de infiltração e $12,77 \%$ de redução de vazão de pico e 9,57\% de redução de volume (TR 100 anos) com o uso de telhados verdes. Simulando as técnicas compensatórias mais eficientes funcionando em conjunto, foram obtidas reduções de $59,00 \%$ de vazão de pico e $46,37 \%$ de redução de volume para precipitações de tempo de retorno de 2 anos e $25,66 \%$ de vazão de pico e $26,45 \%$ de redução de volume em precipitações de 100 anos de tempo de retorno. Assim, concluiu-se que a adaptação de regiões urbanizadas aos princípios da drenagem urbana sustentável é possível e eficiente, e bons resultados podem ser obtidos mesmo nos ambientes mais densamente ocupados. Entretanto, a falta de planejamento durante o desenvolvimento urbano e a pouca disponibilidade de espaço impede a otimização do arranjo espacial dos dispositivos e limita a eficiência de algumas técnicas compensatórias, principalmente aquelas de grande porte.

Palavras-chave: urbanização; SWMM; simulação hidrológica; inundações. 


\section{ABStRACT}

\section{MARTINS, L. G. B. Assessment of application potential of compensatory techniques in}

consolidated urban areas. 2017. 197p. Thesis (PhD) - School of Engineering of São Carlos, University of São Paulo, São Carlos, 2017.

Urban development significantly alters the natural cycle of river basins. With the emergence of sustainable urban drainage, rapid stormwater runoff gave way to recovering the natural characteristics of the river basin through the urban development planning coupled with the use of compensatory techniques that promote the infiltration and detention of stormwater. However, in already urbanized basins, the use of compensatory techniques have limited reach, especially by the high impermeabilization of the basins, the lack of concern with drainage during urban sprawl, low space availability and high implementation costs of structural measures of urban drainage. Thus, the principles of sustainable urban drainage are often considered inadequate to consolidated urban environments. Therefore, this study aimed to evaluate the performance of the conjunction use of several compensatory techniques defined after developing suitability maps for the urban basin and hydrologic simulation. We evaluated detention basins, permeable pavements, rain gardens, green roofs, infiltration trenches and individuals cisterns. We assessed the performance of compensatory techniques working individually and working together. Suitability maps were created for positioning and quantification of compensatory techniques in the watershed. The results showed that extensive application of compensatory techniques in an urban environment could lead to significant improvements in peak flow reduction and control of hydrograms volume, with best individual performance up to $35.5 \%$ peak reduction and $32.48 \%$ hydrograms volume reduction (TR 2 years) using infiltration trenches and 12.77\% peak flow reduction and $957 \%$ volume reduction (TR 100 years) using green roofs. Simulating the most efficient compensatory techniques working together, the results shown $59.00 \%$ of peak flow reductions and $46.37 \%$ of volume reduction to 2 -years rainfalls and $25.66 \%$ peak flow reduction and $26.45 \%$ of volume reduction in 100-years rainfalls. Thus, we concluded that the adaptation of urbanized areas to sustainable urban drainage principles is possible and efficient, and good results can be obtained even in the more densely occupied environments. However, the lack of planning for urban development and the limited space availability prevents the optimization of devices spatial arrangement and limits the effectiveness of certain compensatory techniques, especially those large as detention basins.

Key words: urbanization; SWMM; hydrologic simulation; flooding. 


\section{Lista de Siglas e Abreviaturas}

$\begin{array}{ll}\text { SUDS } & \text { Sustainable urban drainage systems } \\ \text { WSUD } & \text { Water sensitive urban design } \\ \text { LID } & \text { Low impact development } \\ \text { BMP } & \text { Best management practices } \\ \text { IPTU } & \text { Imposto predial e territorial urbano } \\ \text { PDDUA } & \text { Plano diretor de desenvolvimento urbano e ambiental } \\ \text { PD } & \text { Plano diretor } \\ \text { PDDU } & \text { Plano diretor de drenagem urbana } \\ \text { SWMM } & \text { Storm water management model } \\ \text { USEPA } & \text { United States environmental protection agency } \\ \text { CN } & \text { Curve number } \\ \text { NRCS } & \text { Natural resources conservations service } \\ \text { SCS } & \text { Soil conservation service } \\ \text { UGRHI } & \text { Unidades de gestão de recursos hídricos } \\ \text { PDDUAS } & \text { Plano diretor de drenagem urbana ambientalmente sustentável } \\ \text { MDE } & \text { Modelo digital de elevação } \\ \text { CDCC } & \text { Centro de divulgação científica e cultural } \\ \text { SIG } & \text { Sistemas de informações geográficas } \\ \text { AOO } & \text { Análise orientada a objeto } \\ \text { SIG } & \text { Sistema de informações geográficas } \\ \text { PDDUAS } & \text { Plano diretor de drenagem urbana ambientalmente sustentável } \\ \text { IDF } & \text { Intensidade-duração-frequência } \\ \text { TR } & \text { Tempo de retorno }\end{array}$




\section{LISTA DE FIGURAS}

Figura 1 - Exemplo de disposição de um poço de infiltração (BAPTISTA; NASCIMENTO; BARRAUD, 2005) .....29

Figura 2 - Microreservatório de águas pluviais (Fonte: http://www.rainharvest.co.za) ...................................30

Figura 3 - Exemplo de telhado verde na Universidade Tecnológica de Nanyang, Singapura .............................31

Figura 4 - Esquema de uma trincheira de infiltração e vista de trincheira real (adaptado de Souza \& Goldenfun, 1993 e www.cob.org)

Figura 5 - Esquema e exemplo de vala vegetada instalada ao longo de arruamento (adaptado de Urbonas \&

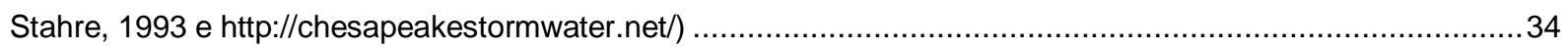

Figura 6 - Funcionamento e exemplo de um jardim de chuva (adaptado de www.kingston.vic.gov.au) ...............35

Figura 7 - Esquema de pavimento permeável e um exemplo de concreto permeável e blocos vazados (adaptado

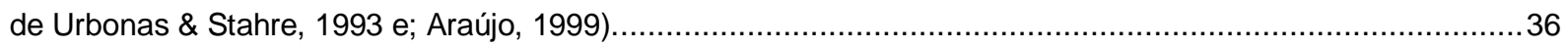

Figura 8 - Bacia de detenção e bacia de retenção na cidade de Porto Alegre (http://www2.portoalegre.rs.gov.br)

Figura 9 - Escoamento superficial representado pelo modelo SWMM (adaptado de Rossman, 2010).....

Figura 10 - Áreas representativas e fluxo do escoamento em bacias normais e bacias com "controles LID"

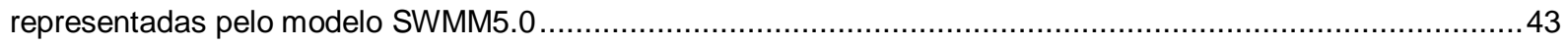

Figura 11 - Representação de Pavimento permeável por camadas e interação entre as camadas existentes .....46 Figura 12 - Bacia hidrográfica do Córrego do Gregório ...................................................................52

Figura 13 - Localização das medidas estruturais na bacia do Gregório (adaptado de PMSC, 2011) ................54

Figura 14 - Exemplo de álgebra de mapas com matrizes numéricas...................................................70

Figura 15 - Mapa de pedologia da área de estudos utilizado no processo de álgebra de mapas.......................71

Figura 16 - Mapa de arruamento da área de estudos utilizado no processo de álgebra de mapas .....................72

Figura 17 - Mapa de declividade da área de estudos classificados em declividades superiores e inferiores a 5\%73

Figura 18 - Mapa de profundidade de lençol freático da área de estudos....................................................73

Figura 19 - Mapa de uso e ocupação do solo da área de estudos utilizado no processo de álgebra de mapas ...74 Figura 20 - Mapa de distância de córregos delimitando a faixa mínima de 100 metros de distância de corpos de

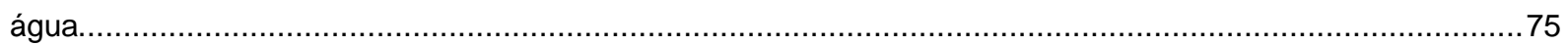

Figura 21 - Rede de drenagem em SIG em 3 etapas: (A) determinação da direção de fluxo (B) linhas de fluxo e

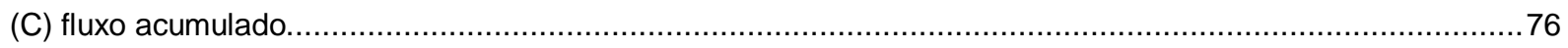

Figura 22 - Processo de obtenção de linhas de fluxo superficial em área urbana ..........................................76

Figura 23 - Criação de linhas de fluxo de drenagem em área urbana ........................................................77

Figura 24 - Mapa de área de drenagem superficial de cada rua da bacia hidrográfica ....................................78

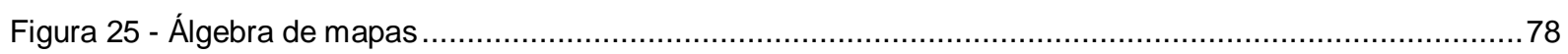

Figura 26 - Ilustração do processo de álgebra de mapas para a produção do mapa de adequabilidade à implantação

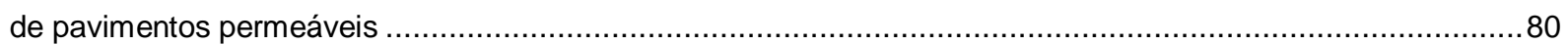

Figura 27 - Armazenamento de água pelas trincheiras segundo sua inclinação ......................................... 82

Figura 28 - Comparação entre precipitações sintéticas pelo método dos blocos alternados .............................86

Figura 29 - Representação da bacia hidrográfica do Córrego do Gregório conforme inserida no modelo SWMM88 Figura 30 - Representação de uma bacia hidrográfica com mais de um tipo de LID no SWMM ...................... 105

Figura 31 - (A) Representação de uma bacia hidrográfica mista da maneira convencional e (B) desmembramento da bacia em duas parcelas dedicadas no modelo SWMM. 106 
Figura 32 - (A) Representação de uma bacia hidrográfica com LID apenas por parcelas dedicadas; (B) representação da bacia por parcelas dedicadas e; (C) representação da bacia apenas por parcelas mistas no modelo SWMM.

Figura 33 - Representação de uma bacia hidrográfica com técnicas compensatórias na fonte, lineares e centralizadas funcionando em conjunto no modelo SWMM ..... 108

Figura 34 - Classificação do uso e ocupação do solo por análise orientada a objetos.................................111

Figura 35 - Adequabilidade da área de estudos à implantação de pavimentos permeáveis ..........................114

Figura 36 - Adequabilidade da área de estudos à implantação de jardins de chuva lineares..........................115

Figura 37 - Adequabilidade da área de estudos à implantação de telhados verdes ...................................116

Figura 38 - Adequabilidade da área de estudos à implantação de Trincheiras de Infiltração Lineares ..............117

Figura 39 - Adequabilidade da área de estudos à implantação de dispositivos de infiltração na fonte ...............118

Figura 40 - Adequabilidade da área de estudos à implantação de microreservatórios ..................................119

Figura 41 - Hietogramas pelo método dos Blocos Alternados com duração de 60 minutos e diferentes Tempos de Retorno

Figura 42 - Hietogramas pelo método dos Blocos Alternados com duração de 120 minutos e diferentes Tempos de Retorno 122

Figura 43 - Hidrogramas para a bacia hidrográfica do córrego do Gregório .................................................124

Figura 44 - Hidrogramas para a bacia hidrográfica do córrego do Gregório............................................125

Figura 45 - Hidrogramas para a bacia hidrográfica do córrego do Gregório ...........................................126

Figura 46 - Registro fotográfico datado de 1974 de trecho canalizado (próximo ao mercado municipal, local exato desconhecido) do córrego do Gregório (Fonte: https://aguasdamemoria.wordpress.com)......

Figura 47 - Hidrogramas de entrada e saída para cada uma das 5 bacias de detenção para tempos de retorno de 10 e 50 anos.

Figura 48 - Localização da maior e da menor bacia de detenção e posicionamento utilizado no cenário alternativo de bacias de detenção.

Figura 49 - Comparação dos hidrogramas do cenário real e do cenário com telhados verdes .144

Figura 50 - Comparação entre hidrogramas do cenário real e do cenário de trincheiras de infiltração para TR 10 anos.

Figura 51 - Comparação entre hidrogramas do cenário real e do cenário de trincheiras de infiltração para TR 100 anos.

Figura 52 - Comparação de hidrogramas entre cenário real e cenário final para TR 2 anos. 156

Figura 53 - Comparação de hidrogramas entre cenário real e cenário final para TR 10 anos..... 157

Figura 54 - Comparação de hidrogramas entre cenário real e cenário final para TR 100 anos 157

Figura 55 - Representação da disposição das técnicas compensatórias e do percurso do escoamento no cenário final

Figura 56 - Comparação das reduções de vazão de pico de cada um dos cenários analisados 160 


\section{LISTA DE QUADROS}

Quadro 1 - Diretrizes técnicas de diferentes manuais para implantação de pavimentos permeáveis.................63

Quadro 2 - Diretrizes técnicas de diferentes manuais para implantação de jardins de chuva lineares ................64

Quadro 3 - Diretrizes técnicas de diferentes manuais para implantação de telhados verdes..............................65

Quadro 4 - Diretrizes técnicas de diferentes manuais para implantação de valas vegetadas ............................66

Quadro 5 - Diretrizes técnicas de diferentes manuais para implantação de trincheiras e poços de infiltração ......67

Quadro 6 - Diretrizes técnicas de diferentes manuais para implantação de microreservatórios individuais ..........68

\section{LISTA DE TABELAS}

Tabela 1 - Controles LID e camadas de representação obrigatórias $(X)$ e opcionais $(\mathrm{O})$ de cada um .................46

Tabela 2 - Identificação das medidas estruturais na bacia do córrego do Gregório .......................................54

Tabela 3 - Classes de cobertura de solo e objetos enquadrados em cada classe ......................................5

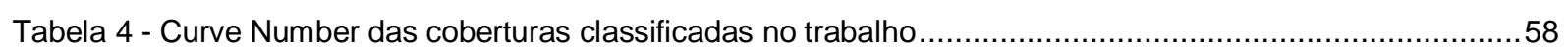

Tabela 5 - Mapas utilizados no processo de álgebra de mapas para cada técnica compensatória .....................79

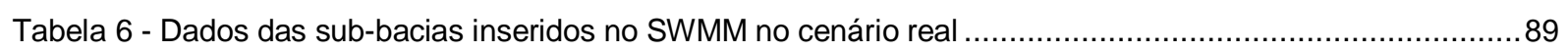

Tabela 7 - Níveis e cota $x$ área $x$ volume da primeira bacia de detenção do córrego Lazzarini .........................91

Tabela 8 - Cota $x$ área $x$ volume da segunda bacia de detenção do córrego Lazzarini ...................................91

Tabela 9 - Cota $x$ área $x$ volume da primeira bacia de detenção do córrego do Gregório...............................91

Tabela 10 - Cota $x$ área $x$ volume da segunda bacia de detenção do córrego do Gregório ...............................91

Tabela 11 - Cota $x$ área $x$ volume da bacia de detenção do córrego Sorregotti ...........................................91

Tabela 12 - Dados do cenário de pavimentos permeáveis inseridos no SWMM ..........................................93

Tabela 13 - Dados de cada camada utilizada na simulação do pavimento permeável ....................................95

Tabela 14 - Dados para o cenário de jardins de chuva lineares ................................................................96

Tabela 15 - Dados de cada camada utilizada na simulação de jardins de chuva ..........................................97

Tabela 16 - Dados para o cenário de $25 \%$ dos telhados sendo telhados verdes ........................................99

Tabela 17 - Parâmetros das camadas do controle LID telhado verde .............................................. 100

Tabela 18 - Dados de sub-bacias para o cenário de trincheiras de infiltração lineares..................................102

Tabela 19 - Valores das camadas das trincheiras de infiltração utilizados na simulação...............................103

Tabela 20 - Dados das sub-bacias para o cenário de microreservatórios individuais.......................................104

Tabela 21 - Dados do controle LID utilizados na modelagem .......................................................... 104

Tabela 22 - Dados das parcelas das sub-bacias utilizados na criação do cenário final ...................................110

Tabela 23 - Valores de áreas, em hectares e percentuais, de cada classe de solo da área de estudos ............112

Tabela 24 - Valores de vazão de pico ( $\left.\mathrm{m}^{3} / \mathrm{s}\right)$ para o exutório da bacia e para o ponto em frente ao mercado municipal para precipitações de 120 minutos no cenário real .................................................................. 128

Tabela 25 - Comparação entre hidrogramas do cenário bacias de detenção em relação ao cenário real para o exutório da bacia

Tabela 26 - Valores de vazão de pico $\left(\mathrm{m}^{3} / \mathrm{s}\right)$ para o exutório da bacia e para o a região do mercado para precipitações de 120 minutos de duração no cenário de bacias de detenção. 
Tabela 27 - Comparação de valores de referência entre hidrogramas do cenário de bacias de detenção e cenário real para a região do mercado municipal

Tabela 28 - Reduções de vazão de pico dos cenários alternativos de bacia de detenção em relação ao cenário real........

Tabela 29 - Valores de vazão de pico $\left(\mathrm{m}^{3} / \mathrm{s}\right)$ para o exutório da bacia e para o a região do mercado para precipitações de 120 minutos de duração no cenário de pavimento permeáveis

Tabela 30 - Comparação entre hidrogramas do cenário de pavimentos permeáveis em relação ao cenário real

Tabela 31 - Comparação de valores de referência entre hidrogramas do cenário de pavimentos permeáveis e cenário real para a região do mercado municipal

Tabela 32 - Comparação entre hidrogramas do cenário de jardins de chuva lineares em relação ao cenário real

Tabela 33 - Comparação de valores de referência entre hidrogramas do cenário de jardins de chuva e cenário real para a região do mercado municipal

Tabela 34 - Comparação entre hidrogramas do cenário de telhados verdes em relação ao cenário real

Tabela 35 - Comparação de valores de referência entre hidrogramas do cenário de telhados verdes e cenário real para a região do mercado municipal

Tabela 36 - Valores de vazão de pico $\left(\mathrm{m}^{3} / \mathrm{s}\right)$ para o exutório da bacia e para o a região do mercado para precipitações de 120 minutos de duração no cenário de telhados verdes 142

Tabela 37 - Comparação entre hidrogramas do cenário de trincheiras de infiltração lineares em relação ao cenário real.

Tabela 38 - Comparação de valores de referência entre hidrogramas do cenário de trincheiras de infiltração e cenário real para a região do mercado municipal

Tabela 39 - Valores de vazão de pico $\left(\mathrm{m}^{3} / \mathrm{s}\right)$ para o exutório da bacia e para o a região do mercado para precipitações de 120 minutos de duração no cenário de trincheiras de infiltração

Tabela 40 - Comparação entre hidrogramas do cenário microreservatórios em relação ao cenário real

Tabela 41 - Comparação de valores de referência entre hidrogramas do cenário de microreservatórios e cenário real para a região do mercado municipal

Tabela 42 - Valores de vazão de pico $\left(\mathrm{m}^{3} / \mathrm{s}\right)$ para o exutório da bacia e para o a região do mercado para precipitações de 120 minutos de duração no cenário de microreservatórios

Tabela 43 - Reduções percentuais de vazão de pico dos cenários alternativos de microreservatórios em relação ao cenário real

Tabela 44 - Comparação entre hidrogramas do cenário final em relação ao cenário real

Tabela 45 - Comparação de valores de referência entre hidrogramas do cenário final e cenário real para a região do mercado municipal.

Tabela 46 - Valores de vazão de pico $\left(\mathrm{m}^{3} / \mathrm{s}\right)$ para o exutório da bacia e para o a região do mercado para precipitações de 120 minutos de duração no cenário Final 


\section{SUMÁRIO}

1 INTRODUÇÃO

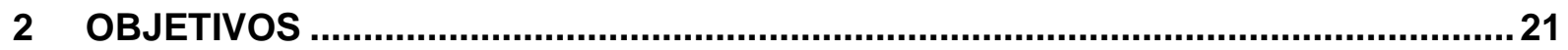

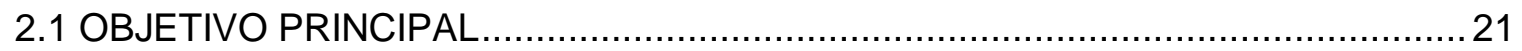

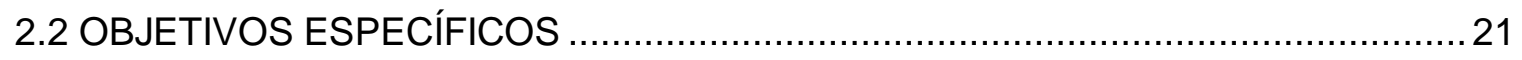

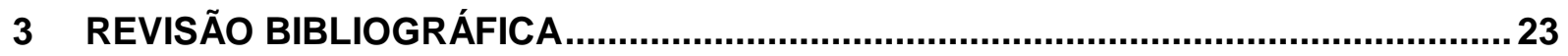

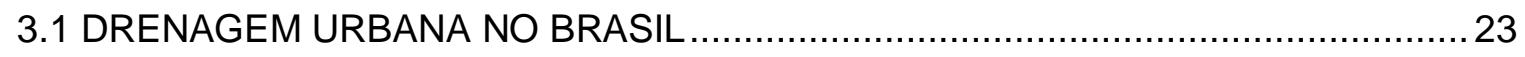

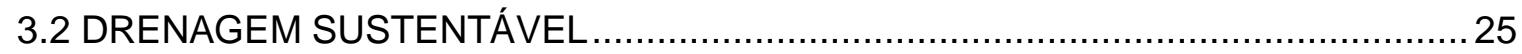

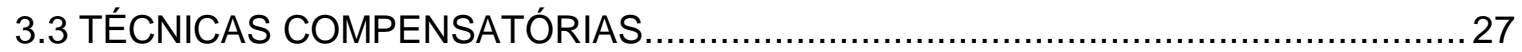

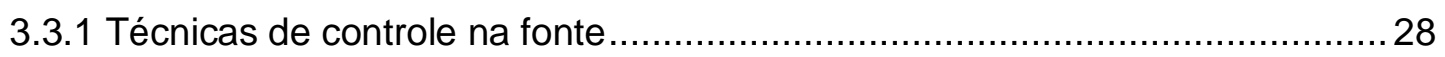

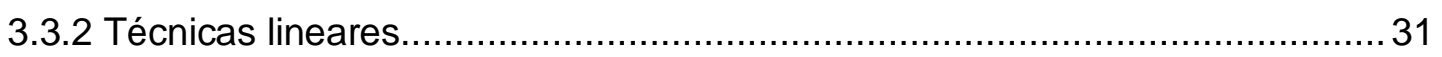

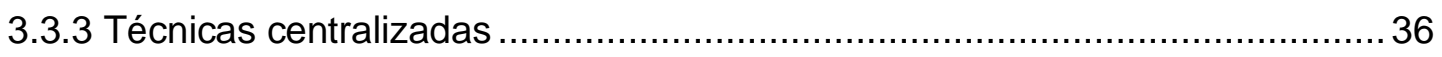

3.4 INCENTIVOS LEGAIS AO USO DE TÉCNICAS COMPENSATÓRIAS .....................37

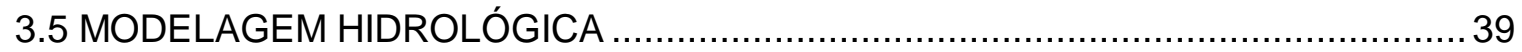

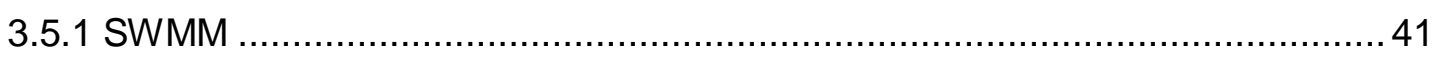

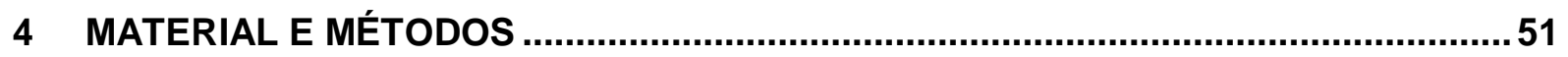

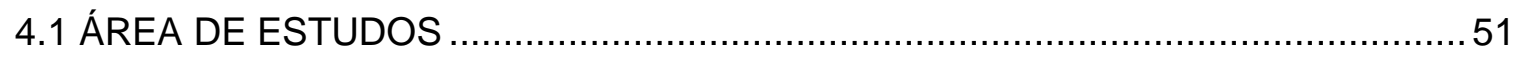

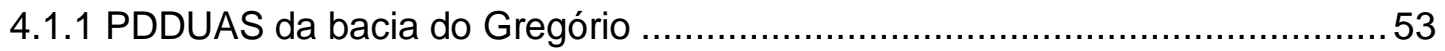

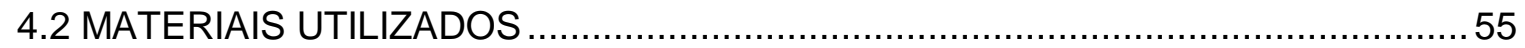

4.3 CLASSIFICAÇÃO DO USO E OCUPAÇÃO DO SOLO DA BACIA...........................56

4.4 PARÂMETROS HIDROLÓGICOS BÁSICOS DA BACIA ....................................59

4.5 ADEQUABILIDADE DA IMPLANTAÇÃO DE TÉCNICAS COMPENSATÓRIAS.......59

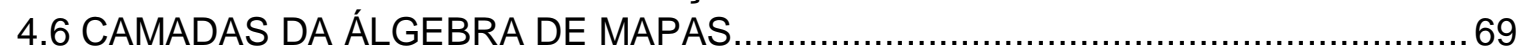

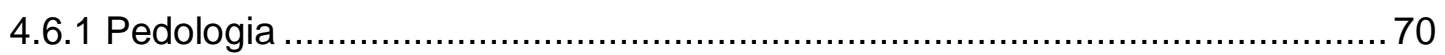

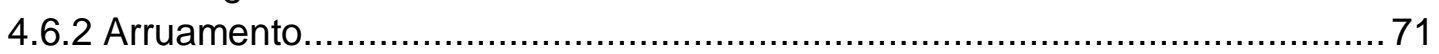

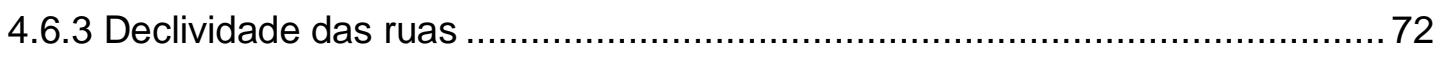

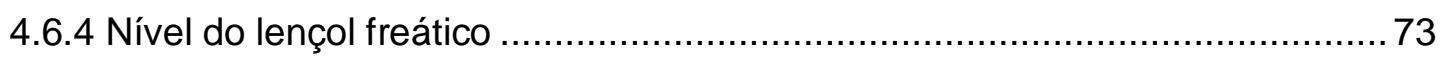

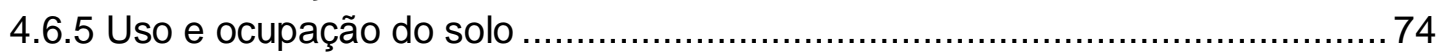

4.6.6 Distância dos córregos ......................................................................... 74

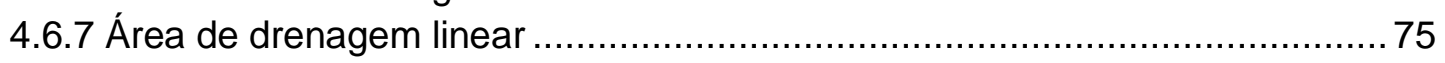

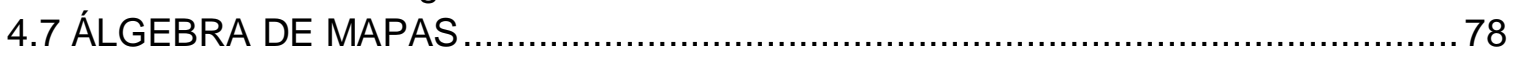

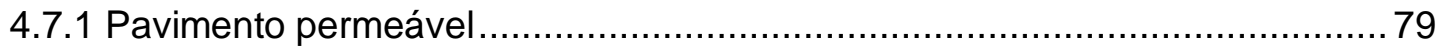

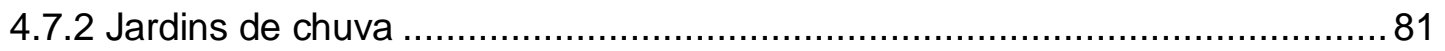

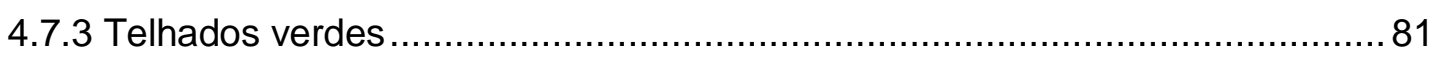

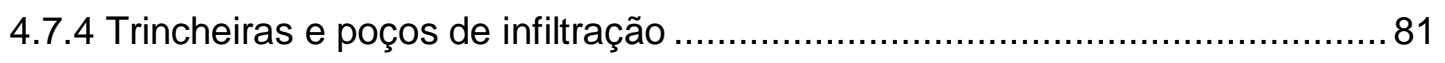

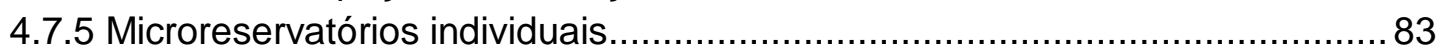

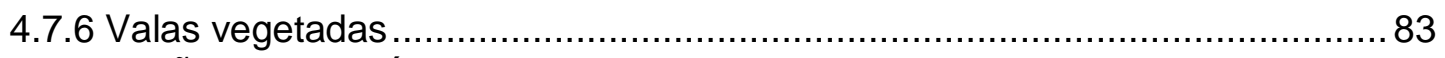

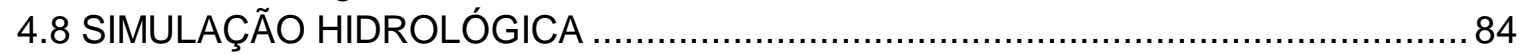

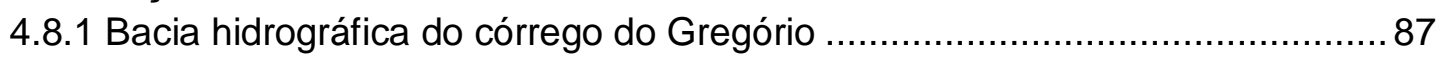

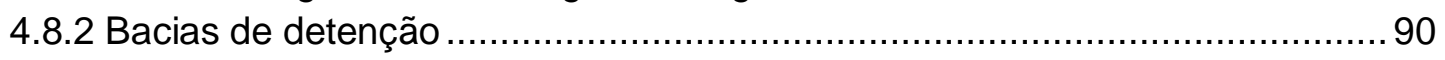

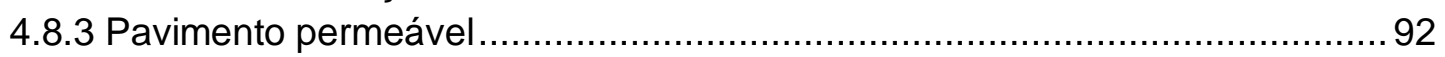

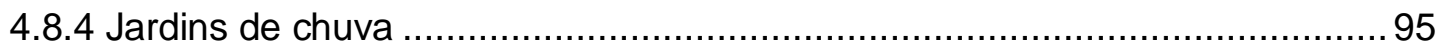

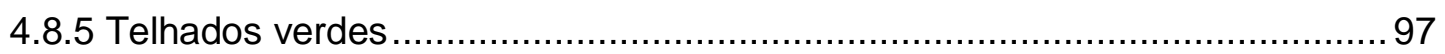

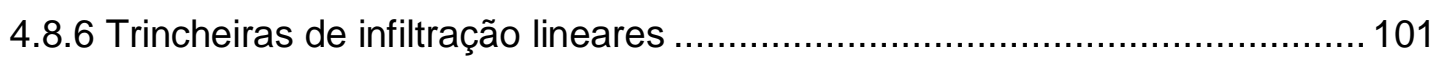




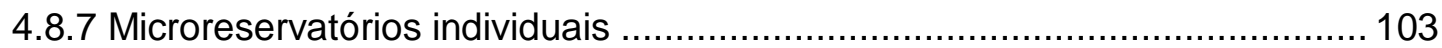

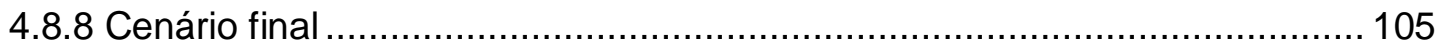

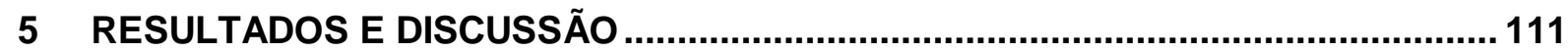

5.1 CLASSIFICAÇÃO DO USO E OCUPAÇÃO DO SOLO NA BACIA ...................... 111

5.2 ADEQUABILIDADE À IMPLANTAÇÃO DE TÉCNICAS COMPENSATÓRIAS ...... 113

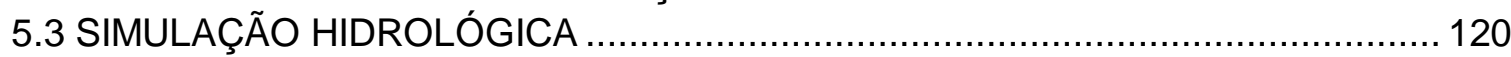

5.3.1 Bacia hidrográfica do córrego do Gregório ............................................... 122

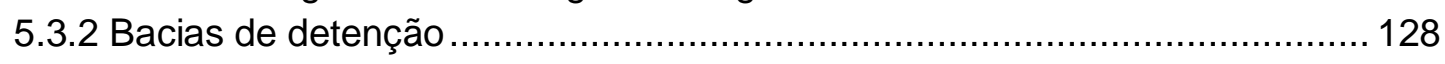

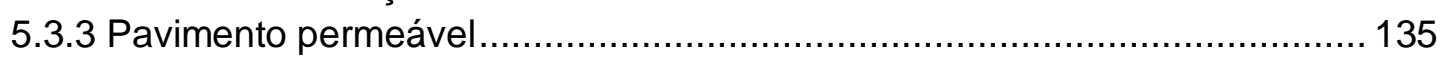

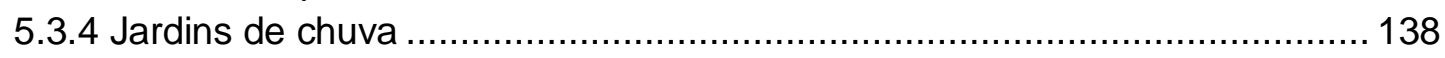

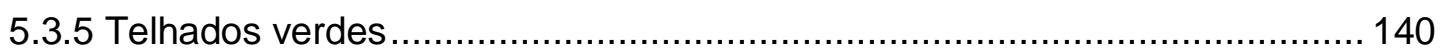

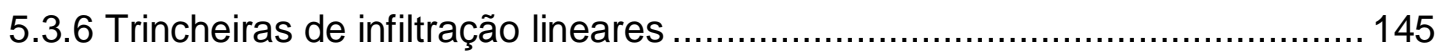

5.3.7 Microreservatórios individuais ........................................................ 151

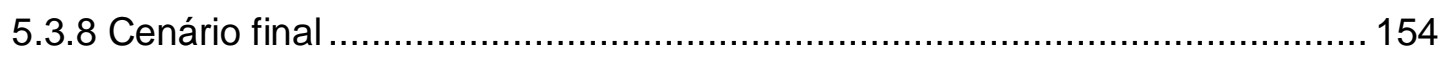

6 CONCLUSÕES........................................................................................... 165

7 RECOMENDAÇÕES ............................................................................... 171

8 REFERÊNCIAS BIBLIOGRÁFICAS ................................................................ 173

APÊNDICE A - MAPAS DE ADEQUABILIDADE À IMPLANTAÇÃO DE DIFERENTES TÉCNICAS COMPENSATÓRIAS.......................................................................... 183

APÊNDICE B - HIDROGRAMAS PARA OS CENÁRIOS HIPOTÉTICOS ......................... 191

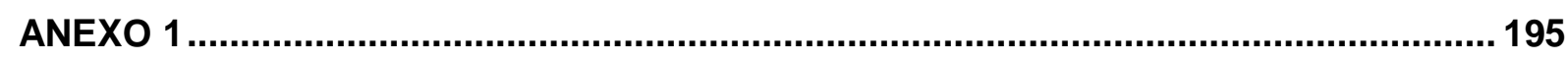

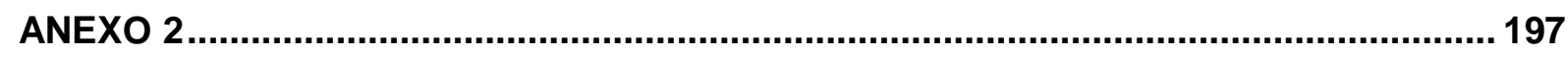




\section{INTRODUÇÃO}

O desenvolvimento urbano altera significativamente o ciclo hidrológico natural de uma bacia hidrográfica. Como consequências principais tem-se o aumento do escoamento superficial direto, incremento das vazões de pico, antecipação do tempo de pico, aumento das cargas poluidoras de origem pontual e difusa, presença de resíduos sólidos e sedimentos nos corpos hídricos, diminuição da recarga subterrânea, alteração dos canais naturais de drenagem, entre outros. O resultado disso é o número cada vez maior de inundações e prejuízos causados por falhas nos sistemas de drenagem.

Historicamente, no Brasil, a drenagem urbana é a parcela de saneamento que menos recebe atenção durante o processo de urbanização. Além disso, a "visão higienista" com a qual se trabalha a drenagem no Brasil já é considerada obsoleta na maior parte do mundo. Ao mesmo tempo, a maior parte dos esforços na solução e manejo dos sistemas de drenagem surge na forma de obras estruturais de caráter corretivo nas redes de micro e macrodrenagem como, por exemplo, a canalização de córregos. Assim, o gerenciamento da drenagem urbana brasileira, em sua maioria, resume-se à busca de soluções por meio de obras de controle de enchentes e inundações.

Ao redor do mundo, a evolução da drenagem urbana se deu através de uma mudança na maneira de se lidar com as águas pluviais. Se antes o objetivo de um sistema de drenagem clássico era escoar as águas pluviais o mais rápido possível para longe das cidades, hoje se busca recuperar as características naturais de escoamento através da redução do volume de água escoado em áreas urbanas a níveis pré-urbanização da bacia. Desta forma, o antigo objetivo de afastamento do escoamento e aceleração do transporte de águas pluviais dá lugar ao controle do volume de escoamento gerado e o retardo desta descarga nos canais principais, a fim de se amenizar o pico de vazão e diminuir seus impactos. Esta nova abordagem recebeu o nome de drenagem urbana sustentável.

A drenagem urbana sustentável tem por objetivo o controle tanto da quantidade quanto da qualidade das águas pluviais utilizando conceitos como controle da produção de escoamento superficial, aumento do tempo de trânsito do escoamento, 
maior integração dos rios à paisagem urbana, remoção de poluentes da água, entre outros. Para tanto, além de um planejamento da drenagem pluvial integrado ao desenvolvimento das cidades, faz-se uso de dispositivos compensatórios, também chamados de técnicas compensatórias, que são estruturas que buscam compensar, através principalmente de infiltração e retenção, os efeitos da urbanização na bacia hidrográfica. Como exemplo, podem-se citar as trincheiras de infiltração e pavimentos permeáveis que promovem a infiltração das águas pluviais, células de bioretenção e jardins de chuva que visam principalmente a remoção de poluentes do escoamento e as bacias de detenção e telhados verdes que detém a água temporariamente promovendo a redução e adiamento da vazão de pico nos canais principais.

Assim, o controle do escoamento superficial e a gestão das águas pluviais são possíveis através de um planejamento eficaz de medidas estruturais e não estruturais que permitirão um manejo das águas pluviais de maneira harmoniosa com a ocupação urbana. Durante o desenvolvimento das zonas urbanas, a aplicação de medidas estruturais como adequação de canais, construção de reservatórios de detenção e estruturas de infiltração é essencial para compensar o aumento de produção de escoamento causado pelo surgimento de áreas impermeáveis na bacia. Além disso, medidas não estruturais como planos diretores visando o ordenamento do uso do solo na bacia e a garantia de recursos e áreas voltadas ao manejo das águas pluviais, zoneamento de áreas de risco e seguros contra inundações são igualmente essenciais para a harmonia do sistema.

Sabe-se que, se planejadas e executadas durante o desenvolvimento urbano, o uso de técnicas de drenagem sustentável tem bons resultados no controle da produção de escoamento e gestão de águas pluviais. Em bacias já urbanizadas, entretanto, os problemas de drenagem urbana tendem a ser mais críticos e, geralmente, espera-se que a aplicação de uma série de medidas estruturais para controle do escoamento superficial seja suficiente para reduzir o volume de escoamento e mitigar ou diminuir a frequência de inundações e outros problemas relacionados às precipitações.

A aplicação de técnicas compensatórias em áreas urbanas já consolidadas é bastante difícil não só pelos custos de implantação, mas também pela dificuldade de se escolher e alocar os dispositivos compensatórios e grandes estruturas por toda a bacia, além também da falta de garantias de que isto traga efetivamente melhoras ao sistema de drenagem urbana. Assim, este trabalho aplica uma metodologia simples 
de escolha e distribuição de técnicas compensatórias em uma bacia hidrográfica densamente urbanizada e avalia, por meio de simulação hidrológica, o resultado das técnicas compensatórias aplicadas trabalhando de maneira individual e de maneira conjunta no controle da produção de escoamento. 


\section{OBJetivos}

\subsection{OBJETIVO PRINCIPAL}

Avaliar o desempenho de técnicas compensatórias aplicadas de maneira extensiva em uma bacia hidrográfica urbana densamente urbanizada através de modelagem hidrológica para averiguar qual o seu potencial de mitigação dos efeitos da urbanização desordenada no sistema de drenagem urbana.

\subsection{OBJETIVOS ESPECÍFICOS}

- Realizar o diagnóstico do uso e ocupação de solo e parâmetros hidrológicos da bacia hidrográfica através de SIG e sensoriamento remoto;

- Desenvolver metodologia para planejamento da aplicação de técnicas compensatórias de maneira extensiva em áreas urbanizadas em escala de bacia hidrográfica;

- Simular individualmente o efeito da implantação de diferentes técnicas compensatórias ao longo da bacia hidrográfica;

- Avaliar o desempenho individual das técnicas compensatórias e escolher as mais eficazes no controle do escoamento superficial;

- Simular e avaliar o efeito, no escoamento superficial, da aplicação extensiva das técnicas compensatórias mais eficazes trabalhando de maneira conjunta em toda a bacia. 


\section{REVISÃo BIBLIOGRÁFICA}

Neste capítulo é apresentada a revisão bibliográfica para fundamentação teórica e contextualização do trabalho. São descritos assuntos relacionados à drenagem urbana, planejamento integrado, problemas relacionados aos atuais modelos de gestão de águas pluviais, além de novas técnicas e recursos utilizados no manejo sustentável das águas pluviais e técnicas e casos de aplicação ao redor do mundo.

\subsection{DRENAGEM URBANA NO BRASIL}

As inundações representam o principal problema relacionado à drenagem urbana nas cidades. Apesar da possibilidade de ocorrerem de forma natural, a maior parte das inundações é decorrente da excessiva impermeabilização das bacias hidrográficas, a qual aumenta consideravelmente a quantidade de escoamento das águas pluviais (CANHOLI, 2005). Além disso, a falta de controle no uso e ocupação do solo durante o desenvolvimento das cidades resulta na ocupação indevida de áreas de risco, como várzeas e planícies de inundação, aumentando os prejuízos sociais e materiais causados pelas chuvas. A respeito da qualidade dos recursos hídricos, já há algum tempo a urbanização é associada à poluição dos corpos hídricos devido aos esgotos domésticos não tratados e aos despejos industriais. Porém, mais recentemente percebeu-se que parte desta poluição tem origem no escoamento das águas pluviais, que trazem consigo uma grande carga de sedimentos e poluentes gerados pelo processo de urbanização, influenciada também pelo uso e o tipo do solo (POLETO \& CHARLESWORTH, 2010).

Historicamente, no Brasil, os sistemas de drenagem urbana sempre utilizaram a abordagem "higienista", que tem por objetivo escoar as águas pluviais para fora da bacia hidrográfica o mais rápido possível (BAPTISTA; NASCIMENTO; BARRAUD, 2005). Além disso, o típico crescimento urbano acelerado brasileiro, juntamente com problemas institucionais e políticos, responsáveis pela falta de políticas públicas para implementação de estruturas básicas de saneamento, resultam em cidades com sistemas de drenagem urbanos insuficientes e ineficientes sem quaisquer planos de manejo (SOARES; PARKINSON; BERNARDES, 2005). Uma vez desenvolvidas as 
cidades, grande parte dos esforços e recursos concentra-se na solução de problemas causados por esses sistemas ineficientes de drenagem urbana, configurando uma gestão corretiva. As soluções mais utilizadas para casos de inundações, enchentes e alagamentos urbanos surgem na forma medidas estruturais nas redes de micro e macrodrenagem como, por exemplo, a construção de reservatórios de detenção e retenção, diques de contenção de cheias ou mesmo aumento de leito de rios ou canalização, visando a solução de problemas locais (CANHOLI, 2005). Entretanto, sabe-se que o transporte rápido do escoamento em meio à crescente impermeabilização do espaço urbano apenas transfere o problema para outro local, contribuindo para o aumento da ocorrência de inundações à jusante das áreas de atuação, representando, portanto, uma medida ineficiente e de alto custo, geralmente financiados pelos cofres públicos. Este quadro de correção de consequências acontece até os dias atuais devido à ausência de planejamento e planos de manejo e, em muitos casos, devido à resistência de profissionais da área de drenagem urbana às novas tecnologias (WRIGHT \& HEANEY, 2001; CANHOLI, 2005; BARBOSA; FERNANDES; DAVID, 2012; GOLDENFUN et al. 2007).

O modo como se lida com a drenagem urbana no Brasil, desde a concepção dos sistemas de macrodrenagem até a forma como se planeja a ocupação urbana encontra-se em decadência já há algum tempo. Pompêo (2000) discute que o gerenciamento da drenagem urbana brasileira se resume somente à busca de soluções por meio de obras de controle de enchentes e inundações, que são definidas após a constatação de algum problema ou catástrofe. Com a obrigatoriedade da criação de planos diretores municipais a partir do ano de 2006, no Brasil, ocorreu um pequeno avanço no sentido de planejamento urbano como um todo. Entretanto, apesar de avanços técnicos inegáveis, o planejamento urbano no Brasil parece ter contribuído pouco para o desenvolvimento e implantação de políticas públicas urbanas capazes de lidar com os problemas essenciais das cidades, principalmente na área de drenagem urbana.

No mundo, mudanças na linha de pensamento sobre a área da drenagem urbana fizeram-se presentes nas últimas décadas, principalmente nos países desenvolvidos, e estas novas concepções, em sua maioria, tem como princípio a reprodução das condições de escoamento apresentadas pela bacia antes da urbanização, ou seja, reduzir o volume de escoamento superficial e aumentar a parcela de infiltração no solo (CHAHAR; GRAILLOT; GAUR, 2012; HAMEL; DALY; 
FLETCHER, 2013). Esta inovação no princípio do gerenciamento das águas pluviais recebeu o nome de drenagem urbana sustentável (KIRBY, 2005) e envolve novos conceitos de planejamento com o uso de novas tecnologias em drenagem urbana.

\subsection{DRENAGEM SUSTENTÁVEL}

A expressão Drenagem Urbana Sustentável engloba a maioria das mudanças surgidas na maneira de se lidar com águas pluviais ao redor do mundo, principalmente em regiões mais desenvolvidas como a América do Norte e Europa. As principais mudanças estão na concepção dos novos sistemas de drenagem, que tem por princípio reproduzir as condições de escoamento apresentadas pela bacia antes da urbanização, ou seja, reduzir o volume de escoamento superficial e aumentar as taxas de infiltração no solo, evitando-se a rápida transferência do escoamento para jusante. Esta nova abordagem recebeu o nome de "compensatória", e considera os impactos da urbanização de forma global, tomando a bacia hidrográfica como unidade de planejamento e buscando compensar, sistematicamente, os efeitos da urbanização. (BAPTISTA; NASCIMENTO; BARRAUD, 2005; CHAHAR; GRAILLOT; GAUR, 2012; FLETCHER et al. 2015). Tais resultados podem ser obtidos por meio de combinações de soluções tecnológicas que aumentam a parcela de infiltração e o tempo de trânsito do escoamento superficial através de dispositivos hidráulicos chamados dispositivos compensatórios ou simplesmente técnicas compensatórias.

Para a compensação dos efeitos da urbanização nas bacias hidrográficas, as soluções mais adotadas são (BAPTISTA; NASCIMENTO; BARRAUD, 2005): bacias de detenção ou retenção, que amortecem a onda de cheia pelo armazenamento permanente ou temporário da água pluvial escoada; estruturas de infiltração, como valas, trincheiras e poços de infiltração; pavimentos permeáveis que infiltram e/ou armazenam temporariamente as águas pluviais; canalizações de canais que visam favorecer o escoamento lento ou até mesmo a detenção temporária das águas e; tratamento de fundos de vale, com zoneamento de planícies de inundação e delimitação de áreas non aedificandi. Estas técnicas compensatórias estruturais podem ser divididas entre centralizadas ou não centralizadas. As centralizadas concentram-se em grandes obras que regulam o ciclo hidrológico de grandes áreas de contribuição, enquanto as não centralizadas espalham-se em várias unidades ao 
longo das áreas de controle, atuando, na maioria das vezes, em nível de lotes urbanos.

Apesar de grandes mudanças na estrutura responsável por lidar com as águas pluviais, a drenagem urbana sustentável atua em diferentes níveis de decisão, englobando a esfera administrativa e política, e em escala regionais e locais, por exemplo. Em comum em todos os níveis é a necessidade de compreensão das possibilidades e consequências de cada decisão tomada. Assim, informações sobre características da área de estudos e dos efeitos da implantação de drenagem sustentável na área são de grande valia e podem ser conseguidas com estudos técnicos, monitoramento hidrológico, revisão de literatura e ferramentas de modelagem, comuns na área de drenagem urbana (BARBOSA; FERNANDES; DAVID, 2012).

Dentro da drenagem sustentável, com o aumento da preocupação com a qualidade das águas pluviais dentro dos centros urbanos, diferentes conceitos de abordagem das águas pluviais surgiram ao redor do mundo, dentre os quais destacam-se o "Sustainable Urban Drainage Systems" (SUDS), no Reino Unido, o "Water Sensitive Urban Design" (WSUD), na Austrália, e "Low Impact Development" (LID) e "Best Management Practices" (BMP), na América do Norte e Nova Zelândia. Todos estes conceitos de desenvolvimento de baixo impacto (em relação à bacia hidrográfica e corpos hídricos) enquadram-se perfeitamente sob a ótica da drenagem sustentável, possuindo por vezes os mesmos princípios, mas diferentes prioridades quanto ao desenvolvimento urbano e manejo de aguas pluviais. O mais díspar é o conceito de BMP, que não faz referência ao desenvolvimento urbano, mas utiliza técnicas compensatórias associadas ao disciplinamento do manejo de solo (incluindo rotina de atividades, proibições de determinadas práticas, procedimentos preventivos etc.) no combate intenso à poluição de origem pluvial e difusa, embora, na prática, seus princípios sejam mais comumente $(78,2 \%$, segundo Martin, 2007) utilizados no controle de inundações (ELLIOTT \& TROWSDALE, 2007; MARTIN et al., 2007; URRUTIAGUER et al., 2010; FLETCHER et al., 2015).

Em países em desenvolvimento, como o Brasil, o uso dessas práticas inovadoras ainda representa um grande desafio. Algumas experiências brasileiras utilizando técnicas compensatórias, como reservatórios de detenção ou retenção, se mostraram ineficientes ou apresentaram problemas colaterais, como as medidas compensatórias centralizadas e de grande escala implantadas sob a forma de 
"piscinões" ou lagoas em cidades como São Paulo e Belo Horizonte. Nascimento et al., (1999) apontaram falhas de gerenciamento e operação como causa principal da decadência destes reservatórios brasileiros, que acabam se tornando ineficientes com o passar do tempo por acúmulo de resíduos sólidos e sedimentos, causando o assoreamento de seus leitos e diminuindo a capacidade de armazenamento dos mesmos, o que, somado a ineficiências hidráulicas devido à falta de manutenção, anularam o objetivo destes reservatórios, tornando-os mais um problema urbano a ser gerenciado. Além disso, estes reservatórios também são responsáveis por alguns problemas de saúde pública, aumentando a propagação de doenças de veiculação hídrica e degradando a qualidade das águas, pois recebem e acumulam altas cargas de esgotos e resíduos sólidos provenientes da drenagem (ALVES FILHO \& RIBEIRO, 2006; SILVÉRIO \& URBINATTI, 2011).

Atualmente, a compensação dos impactos da urbanização sobre a bacia hidrográfica tem sido mais frequentemente almejada no Brasil, e se torna mais usual à medida que legislações surgem para dar suporte aos gestores públicos na regulação do uso do solo e obrigatoriedade de restrição de vazão efluente de lotes urbanos, assunto que será tratado em capítulos subsequentes (CRUZ \& TUCCI, 2008). Entretanto, os profissionais brasileiros enfrentam problemas quanto à qualidade da água de drenagem e design e execução ruins, o que causa o mal funcionamento de diversos sistemas e que diminui o apoio da comunidade ao uso de técnicas compensatórias (GOLDENFUN et al. 2007).

\subsection{TÉCNICAS COMPENSATÓRIAS}

Atualmente, existem vários tipos de técnicas compensatórias para controle de escoamento usados para os mais diferentes casos. Porém, todos estas baseiam-se em dois princípios básicos, a infiltração a água no solo e a detenção temporal ou permanente da água, sabendo-se que frequentemente pode ocorrer a combinação dos dois em uma mesma estrutura (BAPTISTA; NASCIMENTO; BARRAUD, 2005). Em relação à posição de sua implantação, podemos classificar os dispositivos como técnicas de controle na fonte, técnicas lineares e técnicas para controle centralizado.

Para áreas consolidadas, o limite de atuação das medidas compensatórias é restrito devido à carência de espaços físicos e altos custos de implantação das estruturas hidráulicas. Neste sentido, as medidas de controle de 
escoamento na fonte e, em alguns casos, as técnicas lineares, constituem-se como uma solução bastante interessante e sua utilização complementa o sistema de drenagem já instalado, aumentando sua eficiência (ATCHINSON, 2008; MIGUEZ et al., 2009). Para novos empreendimentos, o uso destas tecnologias faz-se necessário para se atender as normas locais, quando existentes, que geralmente limitam a vazão de saída do lote a um valor igual ou menor do que a vazão de saída antes da edificação do lote. Para áreas em processo de urbanização, um planejamento adequado permite o uso das três técnicas simultaneamente, garantindo máxima eficiência do sistema de drenagem.

\subsubsection{Técnicas de controle na fonte}

Os dispositivos compensatórios implantados na drenagem proveniente de um lote, condomínio ou outro empreendimento individualizado como estacionamentos, parques e passeios são denominados técnicas de controle na fonte. Burns et al. (2012) afirma que estes dispositivos foram inicialmente projetados e utilizados para controle de qualidade de água e controle de pico de hidrogramas, mas foram posteriormente utilizados para reestabelecimento das condições iniciais de regime hidrológico das bacias. Miguez et al. (2009) enumera algumas vantagens do controle na fonte, como menores riscos envolvidos a falhas nos dispositivos, maior versatilidade para implantação em áreas bastante urbanizadas e custos de 25\% a $80 \%$ menores que grandes estruturas, sendo menores quanto mais planas as bacias. Entre os principais dispositivos deste tipo, figuram os poços de infiltração, micro-reservatórios (cisternas) residenciais e telhados verdes.

Os poços de infiltração constituem-se de sistemas pontuais, capazes de drenar pequenas áreas, priorizando a infiltração da água no solo como medida de compensação hidrológica. Estes possuem a vantagem de serem pequenos e discretos, podendo ou não ser integrados com a paisagem urbana. Apesar de mais indicados para zonas de solo com grande permeabilidade, podem ser implantados em áreas pouco permeáveis, desde que estas apresentem boa capacidade de infiltração nas camadas mais profundas do solo (BAPTISTA; NASCIMENTO; BARRAUD, 2005). Na Figura 1 é apresentado um esquema de poço de infiltração e um exemplo deste dispositivo integrado à paisagem local, na cidade de Lyon, França. Poços de infiltração 
podem também receber águas captadas por calhas em telhados, sendo bastante utilizadas para quando há pouca disponibilidade de espaço.

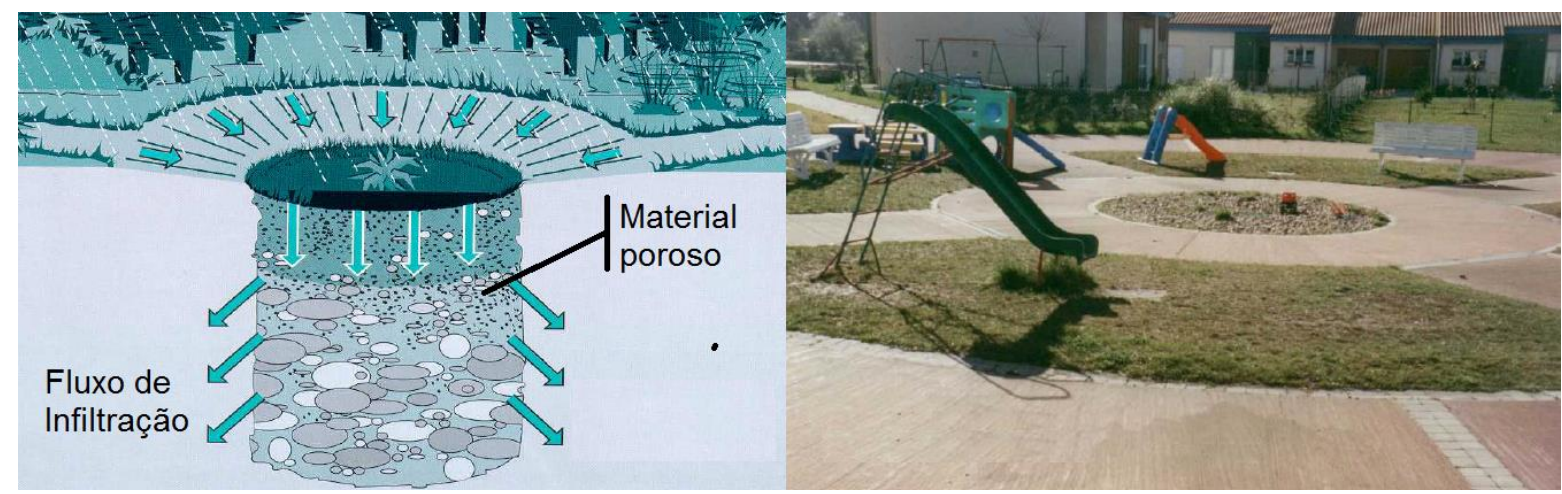

Figura 1 - Exemplo de disposição de um poço de infiltração (BAPTISTA; NASCIMENTO; BARRAUD, 2005)

Os microreservatórios domiciliares, ou cisternas, são dispositivos que buscam o armazenamento permanente ou temporário das águas pluviais. Apesar de não contribuírem para o restabelecimento das parcelas de infiltração naturais das águas pluviais, estas estruturas auxiliam no restabelecimento do ciclo hidrológico natural retardando o tempo de concentração do hidrograma e diminuindo da vazão de pico, além de proverem água para uso doméstico, trazendo assim benefícios aos usuários (WALSH; FLETCHER; BURNS, 2012; GUISI et al., 2009). Estes consistem em um reservatório de água que pode ou não conter dispositivos para controle da qualidade de água, como por exemplo, descarte da primeira água, gradeamento ou filtros (Figura 2). Este tipo de estrutura é fortemente recomendado em abordagens como a WSUD, que incentivam o aproveitamento de águas pluviais para redução do escoamento superficial e diminuição da demanda de água de abastecimento público por parte da população urbana (FLETCHER et al., 2015). 


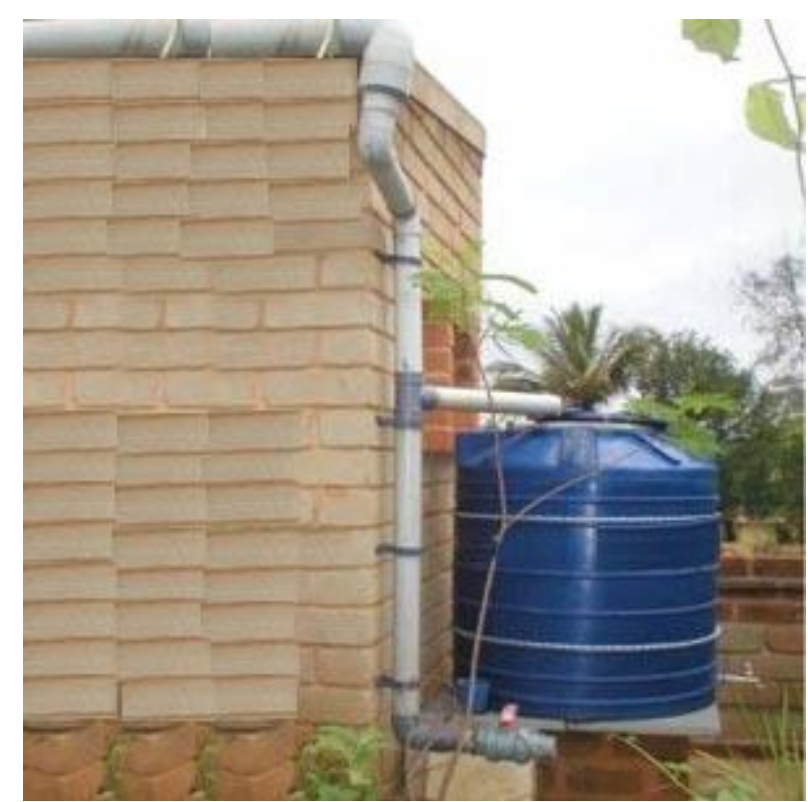

Figura 2 - Microreservatório de águas pluviais (Fonte: http://www.rainharvest.co.za)

Telhados verdes ou armazenadores (Figura 3) são estruturas armazenadoras de águas pluviais instaladas na parte superior de edificações com funções de detenção ou retenção de águas pluviais. Estes podem ser inclinados ou planos e possuir (telhados verdes) ou não (telhados armazenadores) camadas de solo vegetadas. A função hidrológica destes dispositivos é amplamente estudada e comprovadamente eficaz no controle da geração de escoamento e redução das vazões de pico para a maioria dos eventos de precipitação (GNECCO et al., 2013; PALLA et al., 2012; MENTEMS; RAES; HEMRY, 2006; CARTER \& JACKSON, 2007). No caso de telhados verdes, estes possuem ainda funções adicionais como isolamento térmico da edificação, economia de energia em condicionamento climático, embelezamento da paisagem urbana, amenização do micro-clima local, amenização da carga de poluentes provenientes de deposição atmosférica carreados pelo escoamento, redução de barulho na edificação, redução da poluição do ar, entre outros (GNECCO et al., 2013; MENTEMS; RAES; HEMRY, 2006). Telhados verdes se mostram alternativas bastante interessantes no controle do escoamento superficial em áreas densamente urbanizadas, dado aos grandes percentuais de áreas ocupadas por telhados e ao alto custo de terras para instalação de áreas verdes (CARTER \& JACKSON, 2007). 


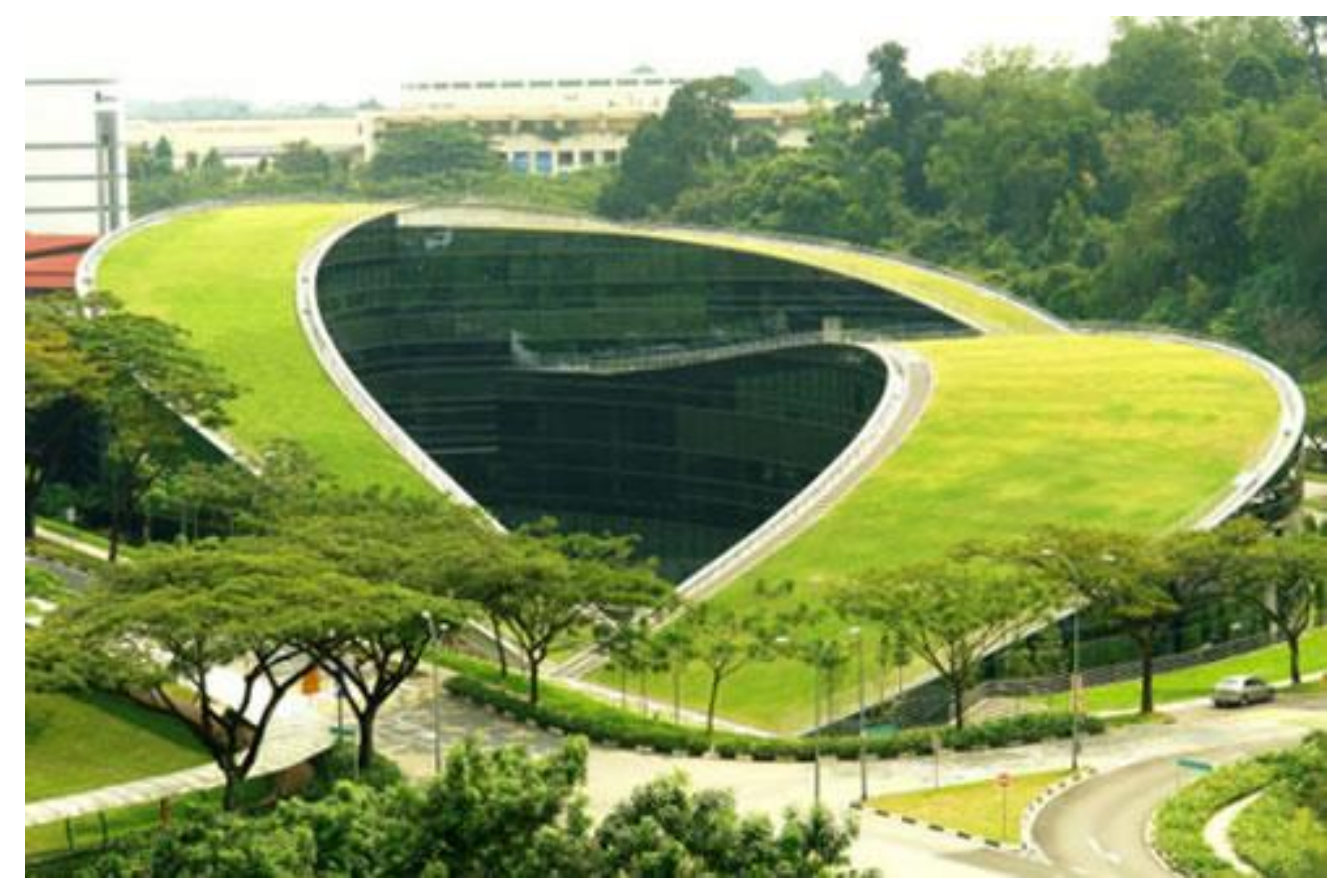

Figura 3 - Exemplo de telhado verde na Universidade Tecnológica de Nanyang, Singapura

Diversos fatores influenciam a capacidade de armazenamento de água em um telhado verde, sendo os principais as características das camadas que o compõem (número de camadas, bem como sua espessura e composição), umidade prévia do solo, temperatura local, tipo de vegetação, formato geométrico e declividade do telhado e idade do telhado (BURSZTA-ADAMIAK \& MROWIEC, 2013). Desta forma, embora Berndtson (2010), em uma revisão bibliográfica de diversos estudos, conclua que telhados verdes são eficientes no controle do escoamento superficial para todos os casos analisados, o desempenho de diferentes telhados verdes varia consideravelmente e sua comparação entre deve sempre considerar a composição e características dos mesmos.

\subsubsection{Técnicas lineares}

Como técnicas lineares, considera-se aquelas implantadas linearmente, geralmente ao longo de sistemas viários - pátios, ruas, calçadões, entre outros - e podem possuir áreas de drenagem pequenas ou grandes. Dentre estas, as principais são as trincheiras de infiltração, valas vegetadas, jardins de chuva e pavimentos permeáveis.

As trincheiras de infiltração são dispositivos lineares que propiciam 0 armazenamento temporário das águas pluviais e promovem sua infiltração, podendo 
ser superficiais ou instaladas em pequenas profundidades. Por serem versáteis, podem ser utilizadas também em residências e outras edificações, além de poderem ser combinadas a valas vegetadas, bacias de detenção, pavimentos permeáveis, entre outros (BAPTISTA; NASCIMENTO; BARRAUD, 2005; CHAHAR; GRAILLOT; GAUR, 2012). A combinação de trincheiras de infiltração com outros dispositivos como pavimentos permeáveis permite a instalação destes dispositivos ao longo de ruas e rodovias sem que se necessite da dedicação de espaço exclusivo para os dispositivos, tornando-os importantes recursos em áreas com pouco espaço disponível ou já desenvolvidas (CHAHAR; GRAILLOT; GAUR, 2012).

Em trincheiras de infiltração, o acesso da água pode ocorrer de maneira superficial ou por meio de um sistema de drenagem, que efetua sua coleta e a introduz na trincheira, que pode ser do tipo infiltração total, na qual a única saída da água afluente é por infiltração no solo, ou infiltração parcial, possuindo drenos para redirecionar a água que excede a capacidade de infiltração do solo de volta ao sistema de drenagem. Um esquema de uma trincheira de infiltração sem drenos, onde o escoamento excedente é vertido pela borda superior, é apresentado na Figura 4.

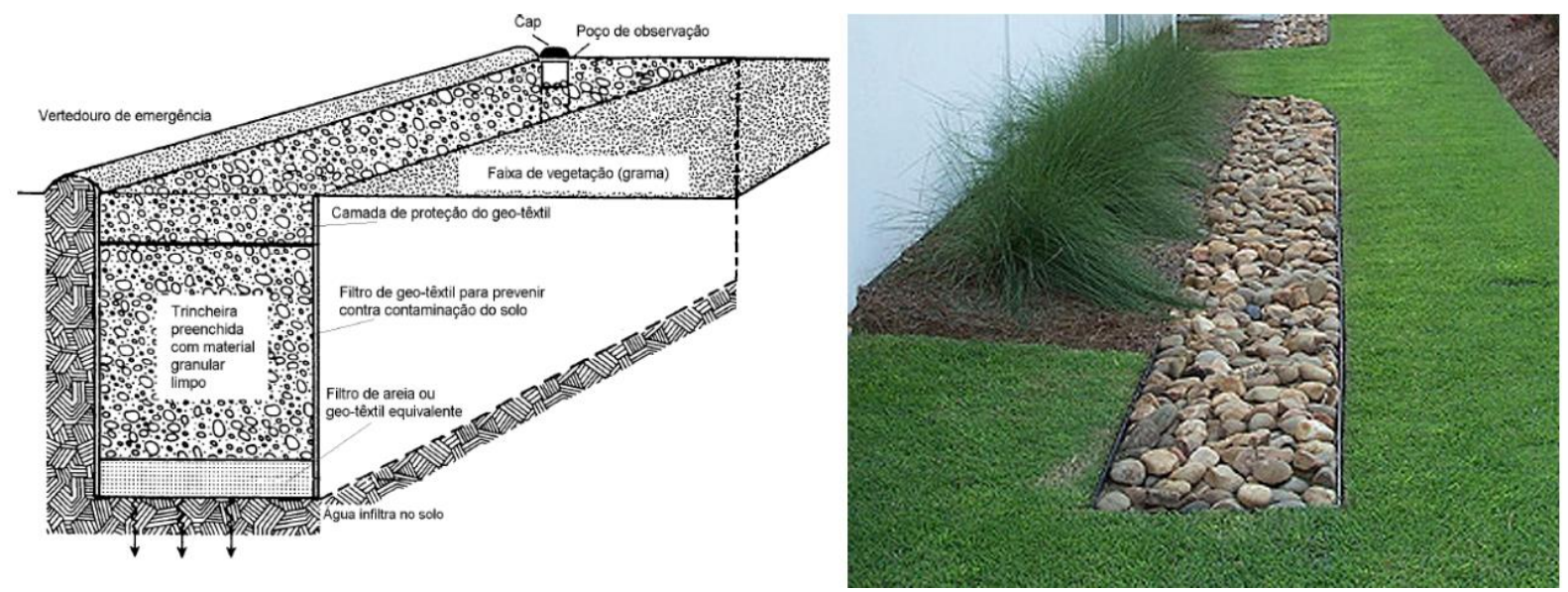

Figura 4 - Esquema de uma trincheira de infiltração e vista de trincheira real (adaptado de Souza \& Goldenfun, 1993 e www.cob.org)

Bach, Deletic e Urich (2013) estudaram, através de simulação hidrológica, a utilização destas trincheiras de infiltração em diferentes tipos de ocupação do solo e concluíram que, para regiões já urbanizadas que possuam solos com boa permeabilidade, estes dispositivos são ideais para controle de escoamento superficial. As trincheiras são especialmente recomendadas em solos permeáveis pois este estes permitem que dispositivos pequenos possuam boa performance, podendo ser implantados até em lotes com pouco espaço disponível. 
Dispositivos de infiltração possuem diversas vantagens como aumento da recarga de águas subterrâneas, redução de salinidade de lençóis freáticos e melhoria da qualidade das águas de drenagem. Entretanto, estes aumentam o risco de poluição de aquíferos, especialmente em solos muito arenosos ou com lençol freático raso, não permitindo a degradação de poluentes presentes na água antes do contato com a zona saturada do solo. Assim, a utilização de dispositivos de infiltração está sujeita a restrições e deve ser analisada cuidadosamente (FISCHER; CHARLES; BAEHR, 2003; BRATTEBO \& BOOTH, 2003).

Outro exemplo interessante de técnica linear são as valas vegetadas ou valas de detenção, depressões escavadas no solo cujo objetivo é o recolhimento das águas pluviais para condução e armazenamento temporário, favorecendo sua infiltração e remoção de nutrientes por decantação, filtração por percolação no solo e processos biológicos, processo pelo qual estes são considerados dispositivos de bioretenção (STAGGE \& DAVIS, 2006). Diversos estudos constataram que valas vegetadas removem significativamente alguns metais, sólidos suspensos, fósforo e nitrogênio do escoamento superficial (BARRET, 2005; LUCKE; MOHAMED; TINDALE, 2014; STAGGE et al., 2012; DELETIC \& FLETCHER, 2006). Entretanto, Barret (2005) pondera que dependendo do evento e da construção das valas, pode haver aumento da concentração, por exportação, de macronutrientes (nitrogênio e fósforo) nas águas pluviais. Para áreas com intensa urbanização, as valas vegetadas dificilmente são utilizadas. Um dos motivos é por que requerem muito espaço para sua implantação (Figura 5), além de não possuírem como objetivo principal o controle do excesso de escoamento, problema mais comum destas áreas. Pode-se citar também que, por sua baixa profundidade, não podem receber escoamento de grandes áreas de drenagem, exigindo diversos dispositivos para tratarem áreas extensas o que, para áreas urbanizadas, inviabiliza sua utilização. 

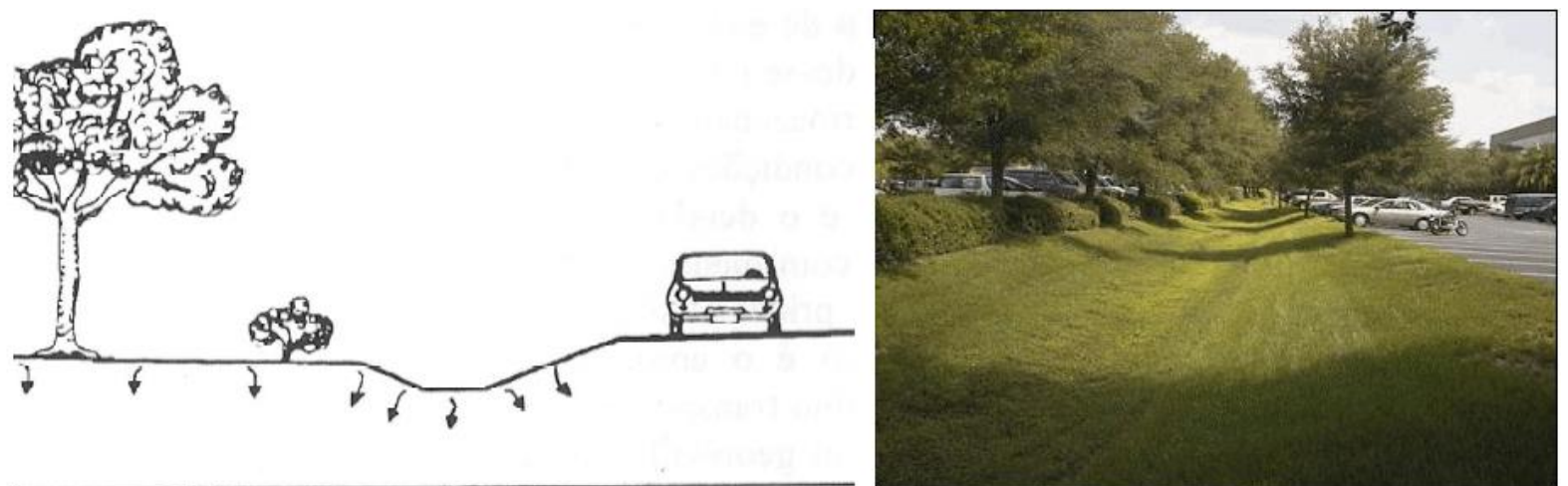

Figura 5 - Esquema e exemplo de vala vegetada instalada ao longo de arruamento (adaptado de Urbonas \& Stahre, 1993 e http://chesapeakestormwater.net/)

Outros dispositivos de bioretenção comumente dispostos linearmente são os jardins de chuva, pequenos espaços ajardinados que recebem escoamento superficial e utilizam a atividade biológica para remover poluentes das águas e que ainda contribuem para a infiltração e retenção dos volumes de água precipitados. Estas estruturas podem ser descritas como rasas depressões de terra, que recebem águas do escoamento superficial (DIETZ, 2007). Os fluxos de água se acumulam nas depressões formando pequenas poças nas quais gradualmente a água é infiltrada no solo. Os poluentes podem ser removidos por adsorção, sedimentação, filtração, adsorção química, atividade biológica e decomposição (DAVIS et al., 2009.) A água retida pode ser infiltrada no terreno para recarga de aquífero ou coletada em um dreno e descarregada no sistema de microdrenagem. No caso de eventos de chuva que excedem a capacidade para a qual a estrutura foi projetada, o fluxo excedente é direcionado ao sistema de drenagem superficialmente. (FCTH, n.d.)

Jardins de chuva (Figura 6), além de serem um dos poucos dispositivos compensatórios com bons índices de tratamento qualitativo e quantitativo de águas pluviais, são versáteis, podem ser dispostos pontualmente ou linearmente e ainda serem combinados a outros dispositivos como, por exemplo, ao fim de uma cisterna, tratando o volume excedente à capacidade de armazenamento do reservatório (AUTIXIER et al., 2014). Apesar disso, os jardins de chuva são pouco utilizados em países em desenvolvimento, tanto pela necessidade de manutenção frequente quanto pela baixa preocupação dos gestores com o controle de poluição difusa em drenagem urbana. 

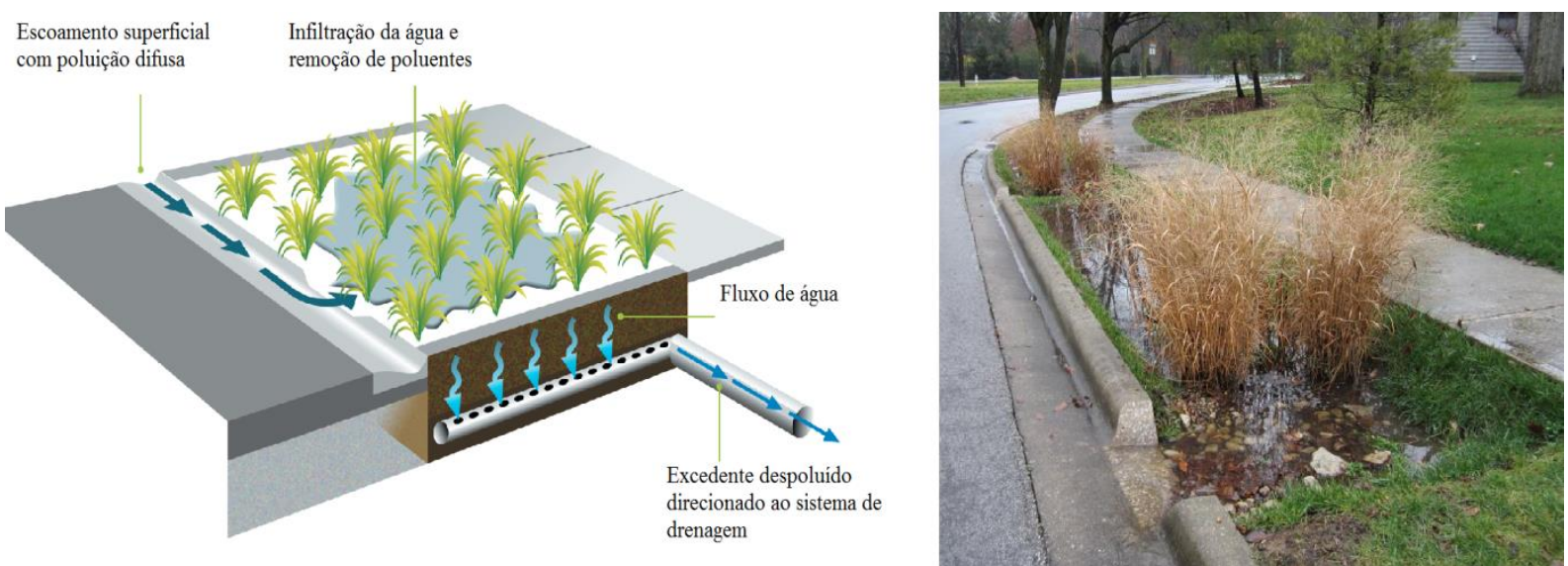

Figura 6 - Funcionamento e exemplo de um jardim de chuva (adaptado de www.kingston.vic.gov.au)

Um dos dispositivos lineares mais utilizados em drenagem sustentável é o Pavimento permeável. Pavimentos permeáveis são definidos como aqueles que possuem espaços livres em sua estrutura por onde a água pode atravessar e possuam a função de suporte ao transporte de veículos (FERGUSSON, 2005). Pavimentos permeáveis são especialmente apropriados para controle de escoamento em áreas urbanas pois, além de reterem água pluvial em seus reservatórios, promovem a infiltração da água, melhoram a qualidade da água escoada pela absorção do "first flux" e, em alguns casos, tratam a água armazenada pela existência de biofilme aderido a seu material granular, funcionando como um reator aeróbio (COUPE et al., 2003; SCHOLZ e GRABOWIECKI, 2007). Além disso, estes pavimentos destacam-se por promoverem a eficiente remoção das águas que precipitam sobre a plataforma da via, evitando aquaplanagem de veículos. Em contrapartida, o custo de instalação desse pavimento é maior em relação ao pavimento convencional, além de exigir manutenção periódica para evitar colmatação dos poros (ARAUJO; TUCCl; GOLDENFUN, 2000; HOLZ \& TASSI, 2007).

Apesar de existirem vários tipos diferentes destes pavimentos, classifica-se como pavimentos permeáveis (ou pavimentos drenantes) desde estruturas complexas com várias camadas até blocos de concreto preenchidos com grama ou mesmo simples paralelepípedos, os quais já promovem uma diminuição do escoamento superficial gerado pelas vias. Os tipos mais comuns de pavimentos permeáveis são (ABUSTAN; HAMZAH; RASHID, 2012): concreto permeável, asfalto permeável, blocos vazados e blocos intertravados. Em comum, todas elas devem possuir 0 pavimento de superfície permeável, uma camada de agregado fino ou médio (geralmente areia, que funciona como um filtro) e uma camada espessa de agregado 
graúdo, que funciona como um reservatório temporário, a partir do qual a água pode ser infiltrada ou direcionada para o sistema de drenagem por drenos (ARAÚJO et al., 2000). A Figura 7 apresenta um esquema de pavimento permeável e suas camadas, um exemplo de concreto permeável e outro exemplo de utilização de blocos vazados.
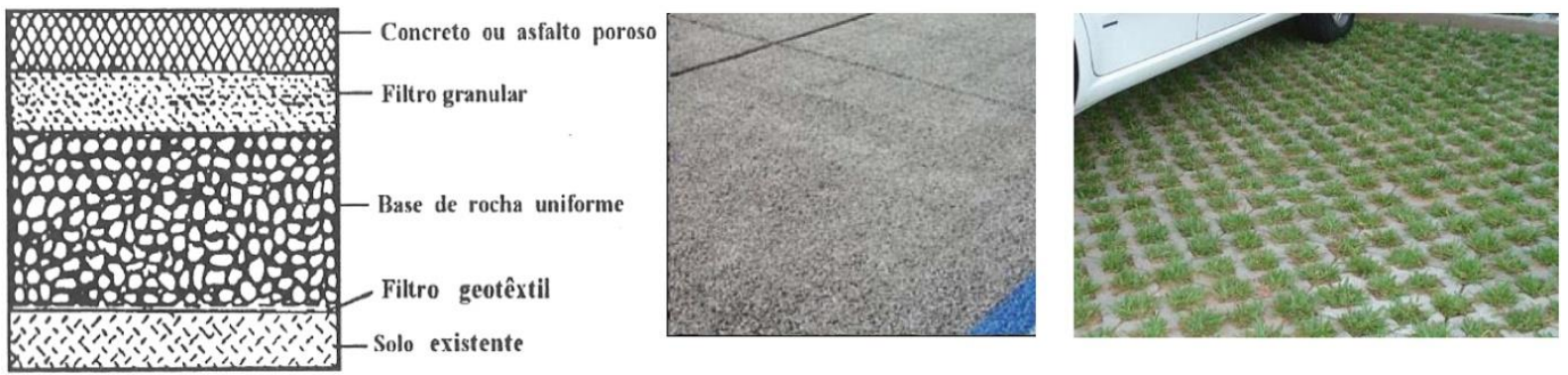

Figura 7 - Esquema de pavimento permeável e um exemplo de concreto permeável e blocos vazados (adaptado de Urbonas \& Stahre, 1993 e; Araújo, 1999).

Para arruamentos com fluxo considerável de carros, recomenda-se o uso de concreto poroso, que nada mais é do que concreto convencional sem o uso de agregados finos, como areia. Desta maneira, garante-se grande permeabilidade ao material e uma considerável resistência. Além disso, Coughlin, Campbell e Mays (2012) afirmam que, mesmo sofrendo colmatação, alguns destes materiais ainda possuem permeabilidade suficiente para amenizar escoamento de precipitações com períodos de retorno acima de 50 anos, desde que bem construídos.

\subsubsection{Técnicas centralizadas}

Técnicas para controle centralizado são aquelas que possuem extensas áreas de drenagem, como as bacias de detenção, retenção e bacias de infiltração. São diversas as formas construtivas destes dispositivos, podendo ser abertas, fechadas, com ou sem espelho de água, in-line ou off-line, entre outros. As bacias de detenção armazenam as águas por um curto período de tempo com finalidade de controle de inundações. As bacias de retenção são grandes reservatórios que armazenam a água por determinado período de tempo, visando controle de inundações e diminuição de cargas de poluição difusa por sedimentação e processos biológicos. Existem também as bacias de infiltração, que visam o armazenamento da água e posterior infiltração no solo (BAPTISTA; NASCIMENTO; BARRAUD, 2005). 
Estas técnicas compensatórias são as mais populares e empregadas no Brasil e foram projetadas em grandes escalas em diversas cidades como São Paulo e Belo Horizonte, onde muitos dispositivos fracassaram no objetivo de controle de inundações e qualidade de água. Nascimento et al., (1999) relatam as experiências brasileiras com este tipo de dispositivo e apontam, como maiores causas do fracasso, a falta de planejamento integrado, o aporte de resíduos sólidos e o despejo de esgotos domésticos nos afluentes do reservatório. Por outro lado, estes reservatórios vêm sendo utilizados em menores escalas com maior sucesso, como mostram dois exemplos apresentados na Figura 8.

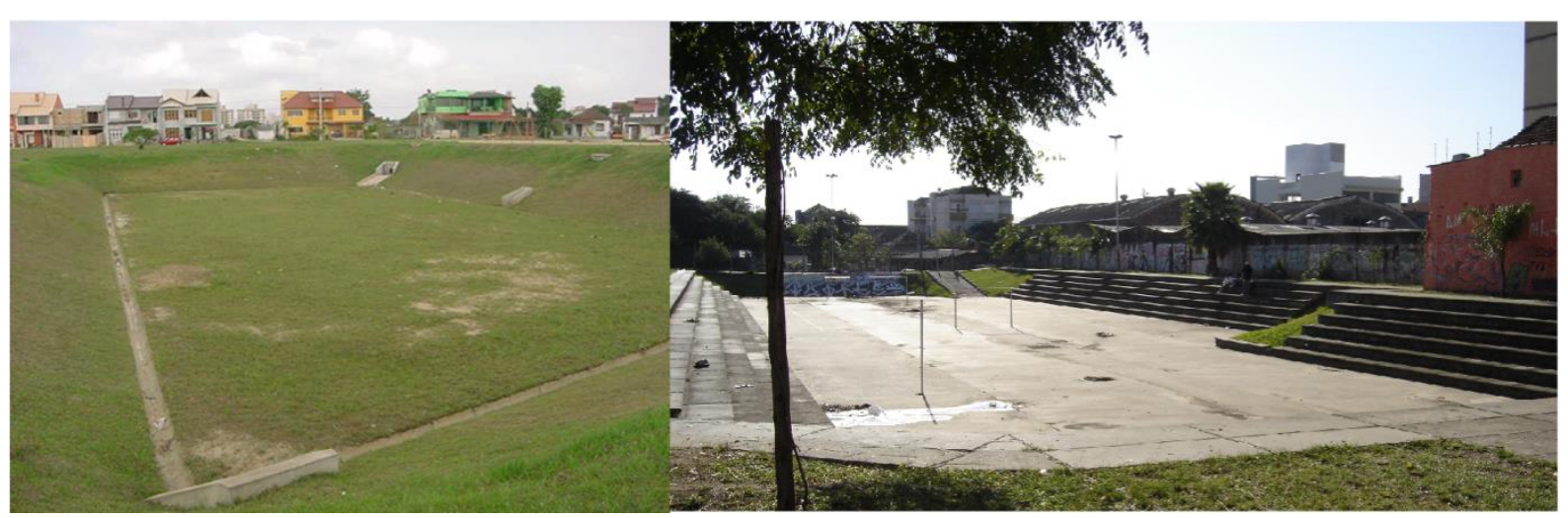

Figura 8 - Bacia de detenção e bacia de retenção na cidade de Porto Alegre (http://www2.portoalegre.rs.gov.br)

\subsection{INCENTIVOS LEGAIS AO USO DE TÉCNICAS COMPENSATÓRIAS}

Com o intuito de promover incentivos legais ao uso de medidas de controle, torna-se interessante a aplicação dos chamados "impostos ambientais". No Brasil, tem-se tentado fomentar o uso destes através de incentivos fiscais na forma de descontos no IPTU (Imposto Predial e Territorial Urbano). Este é um imposto municipal que inclui a propriedade territorial urbana e a propriedade predial incidente sobre o terreno e a edificação respectiva para cálculo do valor venal do imóvel (valor estimado de avaliação do mesmo para compra e venda à vista considerando sua localização e características físicas). Desta forma, iniciativas que colaborassem hidrologicamente ou ambientalmente com o município resultariam em descontos no IPTU.

Algumas cidades já adotam a associação destes incentivos ao IPTU como Porto Alegre, Recife e Manaus, onde são denominados "IPTU Ecológico". Um bom exemplo de incentivo ambiental é Guarulhos-SP que aprovou uma Lei Municipal 
nำ.793/2010 de redução no valor do IPTU para os imóveis que adotem as seguintes medidas: sistema de captação de água da chuva, sistema de reuso da água, sistema de aquecimento hidráulico solar, sistema de aquecimento elétrico solar, construções com material sustentável, utilização de energia passiva, sistema de utilização de energia eólica, instalação de telhado verde, separação de resíduos sólidos (GUARULHOS, 2010).

No município de São Paulo, tem-se o exemplo da "Lei das Piscininhas", apelido dado à Lei 13.276/2002, um marco em legislações municipais para o controle do escoamento pluvial em lote. Esta lei torna obrigatória a utilização de reservatórios para as águas coletadas por coberturas e pavimentos nos lotes, edificados ou não, que tenham área impermeabilizada superior a $500 \mathrm{~m}^{2}$ (PMSP, 2012). A Lei das Piscininhas exige a instalação de um sistema que conduza a um reservatório toda água captada por telhados, coberturas, terraços e pavimentos descobertos, e ainda determina que esta água armazenada deve preferencialmente infiltrar-se no solo, podendo ser despejada na rede pública de drenagem após uma hora de chuva ou ser conduzida para outro reservatório para ser utilizada para finalidades não potáveis. Além disso, as áreas de estacionamentos deverão ter $30 \%$ de sua área com piso drenante (pavimento permeável) ou com área naturalmente permeável. Posteriormente, legislação análoga à do Município de São Paulo acabou sendo adotada para todo o Estado de São Paulo, conhecida por Lei Estadual das Piscininhas (Lei 12.526, de 02 de janeiro de 2007).

Destaca-se também em São Paulo e Porto Alegre a iniciativa estabelecida em Plano Diretor de restrição de vazão de saída de lotes para novos empreendimentos. No Caso de Porto Alegre, através do Decreto Municipal número 15.371/2006, fica limitada como vazão máxima de saída do lote $20,81 /$ s.ha, valor considerado como o máximo nas condições pré-urbanização para precipitação de 60 minutos e 60 milímetros (PORTO ALEGRE, 2006). Para o município de São Paulo, o valor é de 25l/s.ha. Alguns estudos e iniciativas da área acadêmica também propõem medidas de incentivo a essas boas práticas de manejo pluvial como, por exemplo, Mendiondo (2007), que propõe a utilização de um IPTU Hidrológico que variasse à medida que fosse aumentado ou o armazenamento potencial de água no lote e/ou à minimização da vazão máxima instantânea de saída. Para isso, deveriam ser implementadas medidas compensatórias em escala de lote urbano, como no caso das trincheiras de infiltração, telhados verdes etc. 
De modo geral, qualquer norma que estabeleça vazões máximas de saída de lote ou incentivos fiscais quando da utilização de boas práticas de manejo de águas traz benefícios ao ambiente urbano. Entretanto, para o estabelecimento destes valores e utilização destas práticas deve-se ter metas e objetivos, determinados através de planejamentos urbanos e estudos aprofundados das consequências destas mudanças. A principal ferramenta de planejamento urbano é o Plano Diretor de Desenvolvimento Urbano e Ambiental (PDDUA), ou simplesmente Plano Diretor (PD). Em relação à drenagem pluvial, o planejamento é realizado pelo Plano Diretor de Drenagem Urbana (PDDU).

A adoção das medidas preventivas e restritivas de uso de solo urbano é, sem dúvidas, benéfica ao ambiente urbano. Uma maneira de se avaliar os efeitos da adoção destas medidas é através de simulações computacionais que tenham por objetivo reproduzir os efeitos ocasionados pelo uso de ordenamento de solo ou uso de, por exemplo, "piscininhas", piscinões, ou qualquer outra técnica compensatória utilizada por toda a bacia hidrográfica.

\subsection{MODELAGEM HIDROLÓGICA}

Estudos hidrológicos envolvendo processos naturais complexos - como precipitação, escoamento superficial e infiltração - dependem de um grande número de fatores e de suas interações, o que dificulta sua análise quantitativa. $O$ modelo hidrológico é uma ferramenta desenvolvida pela ciência para melhor entender e representar o comportamento da bacia hidrográfica e pode ser definido como "uma representação matemática do fluxo de água e seus constituintes em alguma parte da superfície do solo ou subsolo" (MAIDMENT, 1993). A bacia hidrográfica é um sistema que, a partir da entrada de um estímulo (precipitação), responde através de uma saída (vazão escoada no exutório). Por representarem a bacia, os modelos hidrológicos funcionam da mesma maneira, respondendo através de uma saída (resultados) aos estímulos de entrada (parâmetros hidrológicos).

Alguns modelos hidrológicos relacionados a escoamento superficial tiveram bastante popularidade desde seu surgimento até os dias atuais, dentre os quais podese citar o método SCS (Soil Conservation Service, posteriormente chamado Método NRCS - Natural Resources Conservation Service), o método Racional e o método de Sacramento. Este sucesso deve-se à simplicidade de aplicação dos métodos e, 
sobretudo, aos poucos parâmetros hidrológicos necessários para sua aplicação. Com o aumento da capacidade e acessibilidade de computadores, tornou-se possível a integração de diversos métodos simultaneamente, permitindo modelagens hidrológicas que abordem a bacia hidrográfica como um todo.

Atualmente, diversos modelos hidrológicos computacionais são utilizados ao redor do mundo com as mais diversas finalidades. Destacam-se: nos Estados unidos o HEC-HMS (Hydrologic Engineering Center - Hydrologic Modeling System), utilizado em projetos de sistemas de drenagem, quantificação dos efeitos decorrentes de mudança do uso do solo; o HSPF (Hydrologic Simulation Program-Fortran) usado para modelagem da qualidade da água; o SWAT (Soiland Water Assesment Tools) usado para previsão de feitos de uso e manejo do solo sobre recursos hídricos; o MMS (Modular Modeling System) usado no planejamento de recursos hídricos (BREDA, 2008). Para meios urbanos destacam-se o modelo SWMM (StormWater Management Model), um modelo dinâmico chuva-vazão para a gestão de drenagem urbana; o Mike URBAN, um modelo abrangente para abastecimento de água (que incorpora os softwares gratuito EPANET nesta tarefa) coleta de esgoto e águas pluviais (incorpora o SWMM5 nesta tarefa); e o HydroWORKS, modelo quali-quantitativo para eventos de precipitação, também baseado no modelo SWMM (BUTLER \& DAVIES, 2010).

No Canadá os modelos mais populares para simulação hidrológica são WATFLOOD e UBC (Universtityof British Columbia) Watershed Model. Na Austrália, os modelos RORB (Runoff Routing) e WBN (Waterbody Network) são comumente utilizados na previsão de vazão, projetos de drenagem e avaliação de mudanças no uso do solo. Os modelos TOPMODEL e SHE (Système Hydrologyque Européen) são utilizados na maioria dos países europeus, enquanto que no Japão são o ARNO, LCS e TOPKAPI (Topographic Kinematic Approximation and Integration) (BREDA, 2008).

No Brasil destaca-se o IPH II (TUCCI; ORDONEZ; SIMÕES, 1981), modelo que simula somente o escoamento na superfície da bacia, os modelos $A B C$ - atualmente ABC6 - (LABSID, 2000), um Sistema de Suporte a Decisões para Análise de Ondas de Cheia em Bacias Complexas e por fim o MODCEL (MIGUEZ, 2001), modelo de escoamento em células.

A gama de modelos hidrológicos disponíveis é imensa e a escolha de um modelo hidrológico não é tarefa fácil. Entretanto, pelo conteúdo apresentado, nota-se que apesar de cada região utilizar os modelos produzidos por institutos locais, cada modelo tem um foco principal. Assim, a escolha do modelo ideal deve ser feita 
baseada em critérios como objetivos da modelagem, características da área de estudos, disponibilidade de dados e familiaridade com o modelo. Para este trabalho foi escolhido o modelo SWMM, uma vez que possui todas as funções necessárias para a realização do trabalho, além de um módulo de técnicas compensatórias bastante eficiente na representação de dispositivos de compensação (ELLIOT \& TROWSDALE, 2007).

\subsubsection{SWMM}

O Modelo SWMM (Storm Water Management Model) é um modelo hidrológico de código fonte aberto desenvolvido em 1971 pela USEPA (United States Environmental Protection Agency, a agência de proteção ambiental dos Estados Unidos) (ROSSMAN, 2010). Este trabalha de forma dinâmica a transformação chuvavazão e é capaz de simular séries de precipitação de longa duração ou eventos isolados. Este modelo vem sendo largamente aplicado e estudos hidrológicos e hidráulicos em bacias urbanas. A versão mais atual do modelo, o SWMM versão 5.0, recebeu novos algoritmos que tornam possível a incorporação de técnicas compensatórias na simulação, o que o torna ideal para simulação de cenários futuros utilizando drenagem urbana sustentável (TOMINAGA, 2013).

De acordo com (ROSSMAN, 2010), o modelo é capaz de representar uma série de processos hidrológicos, sendo estes: variabilidade da chuva ao longo do tempo; evaporação de água; acumulo e degelo de neve; interceptação da chuva causada pelo armazenamento em depressões; infiltração da precipitação em solos não saturados; percolação e infiltração da água em aquíferos; troca entre o fluxo da água subterrânea e o sistema de drenagem; propagação do escoamento superficial via modelo do reservatório não linear e; captação e retenção de escoamento superficial com diversas técnicas compensatórias, chamadas no modelo de "controles LID" ou simplesmente "LID". Ao longo das simulações, o modelo aplica os princípios da conservação de energia, de massa e de momento. Os métodos utilizados para as simulações podem ser escolhidos pelo usuário dentro de uma série de métodos disponibilizada pelo software.

O modelo trabalha com variabilidade espacial de precipitação e escoamento, utilizando para tanto a divisão da área de estudos em diversas sub-bacias, menores e mais homogêneas, cada uma com suas respectivas características hidrológicas. 
Além disso, o modelo é capaz de realizar analises qualiquantitativas de problemas relacionados à drenagem urbana, além de investigar alternativas de controle de escoamento, de forma a oferecer informações para estimativas de custo e eficiência dos dispositivos (SHINMA, 2011).

O SWMM possui em seu código diversos métodos para a simulação dos processos hidrológicos, ficando a cargo do operador a escolha dos mais adequados ao estudo. James, Rossman e James (2008) descreveram os diversos processos físicos que resultam na transformação chuva-vazão do modelo: escoamento superficial, infiltração, contribuição de águas subterrâneas, derretimento de gelo, propagação da vazão, acúmulo superficial e propagação da qualidade da água. Os processos de maior interesse para o presente trabalho são escoamento superficial, infiltração e propagação da vazão. Como serão simulados eventos individuais, a parcela de evapotranspiração foi considerada desprezível no trabalho.

Para a modelagem de escoamento superficial, considera-se cada sub-bacia como um reservatório não-linear, nos termos apresentados na Figura 9.

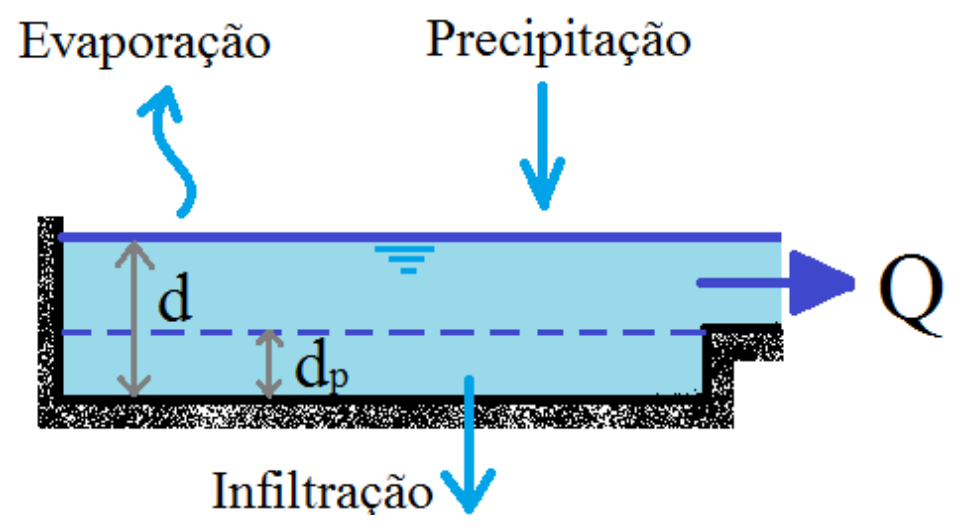

Figura 9 - Escoamento superficial representado pelo modelo SWMM (adaptado de Rossman, 2010)

Conforme descreve Rossman (2010), toda a vazão afluente para este reservatório (que representa uma sub-bacia) provém de precipitações ou de outras sub-bacias a montante. $O$ termo $d_{p}$ refere-se à capacidade de armazenamento do reservatório, representado pelas parcelas de armazenamento em depressões e interceptação, por exemplo. As vazões efluentes são a parcela de infiltração, evaporação e a parcela de escoamento superficial $(Q)$, dada pela expressão:

$$
Q=W \cdot \frac{1}{n} \cdot\left(d-d_{p}\right)^{5 / 3} \cdot S^{1 / 2}
$$


Onde: $\mathrm{W}=$ Largura da sub-bacia $(\mathrm{m})$, sendo a largura média de escoamento.

$\mathrm{n}=$ coeficiente de rugosidade de Manning

$\mathrm{d}=$ profundidade de lâmina de água $(\mathrm{m})$

$\mathrm{d}_{\mathrm{p}}=$ capacidade de armazenamento $(\mathrm{m})$

$\mathrm{S}=$ declividade média da bacia $(\mathrm{m} / \mathrm{m})$

Para a representação da cobertura do solo da bacia e sua parcela de escoamento, caso não haja dispositivos compensatórios, o modelo divide a área em duas: impermeáveis, sem capacidade de detenção e; permeáveis, com capacidade de detenção. Caso sejam empregados controles LID, estes entram como uma terceira categoria de área, podendo ser consideradas permeáveis ou impermeáveis com capacidade de detenção, dependendo do dispositivo implantado. O fluxo da área impermeável divide-se parte para o exutório e parte para o dispositivo compensatório, que redirecionará um possível fluxo efluente ao exutório da bacia. No modelo, escoamento de áreas permeáveis não podem ser direcionados às LID. A Figura 10 ilustra a representação das áreas de uma bacia hidrográfica no modelo.
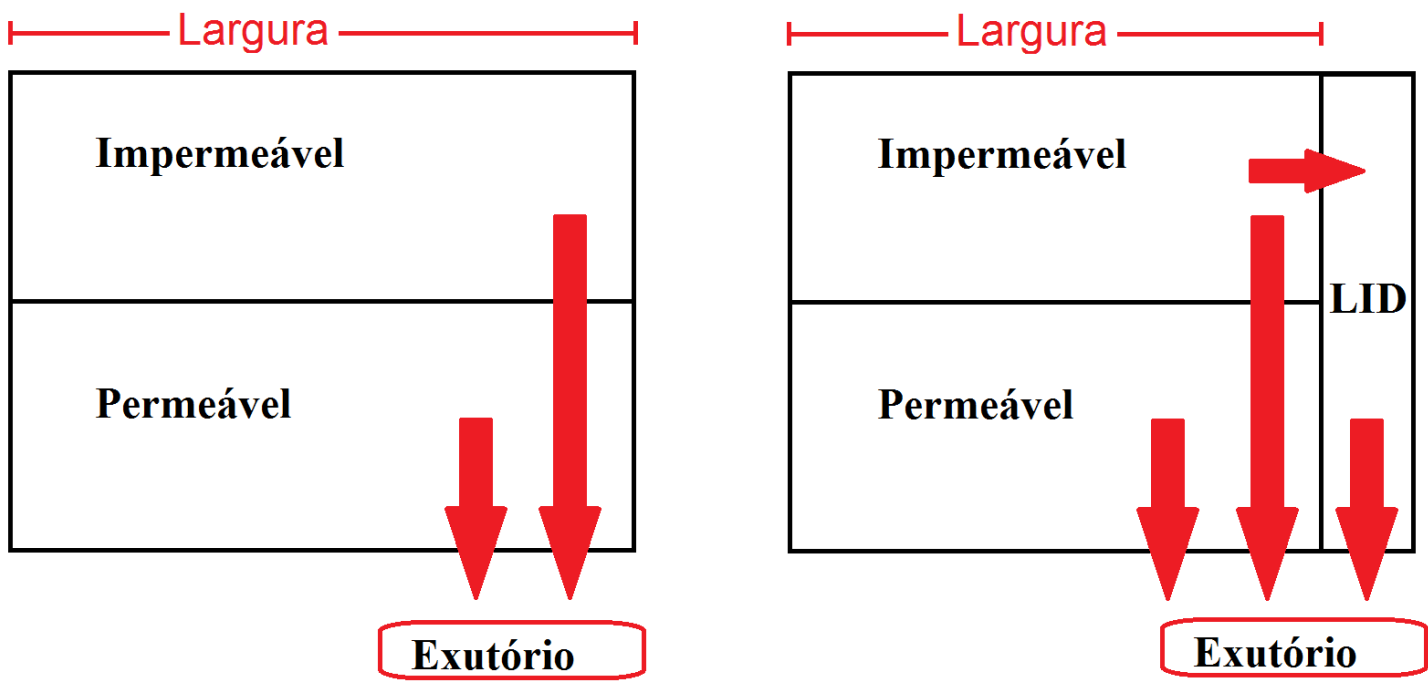

Figura 10 - Áreas representativas e fluxo do escoamento em bacias normais e bacias com "controles LID" representadas pelo modelo SWMM5.0

O processo de infiltração pode ser representado por três diferentes e consagrados métodos, o de Horton, o GreenAmpt e o Curve-Number (CN) do método NRCS (Natural Resources Conservation Service), nos quais os parâmetros que regem o processo devem ser todos fornecidos pelo usuário. 
A propagação de vazão é orientada pela equação de Saint-Venant, representada por duas equações, a equação da continuidade com contribuição lateral e a variação da quantidade de movimento. A equação da contribuição lateral é apresentada a seguir:

$$
\frac{\partial A_{m}}{\partial t}+\frac{\partial Q}{\partial l}=q_{l a t}
$$

Onde: $A_{m}=$ área da seção molhada $\left(m^{2}\right)$

$\mathrm{t}=$ tempo $(\mathrm{s})$

$\mathrm{Q}=\operatorname{vazão}\left(\mathrm{m}^{3} / \mathrm{s}\right)$

I=distância longitudinal $(\mathrm{m})$

$q_{\text {lat }}=$ contribuição lateral por unidade de largura $\left(\mathrm{m}^{3} / \mathrm{s} . \mathrm{m}\right)$

A equação da variação da quantidade de movimento com um volume de controle é representada através da expressão:

$$
\frac{\partial Q}{\partial t}+\frac{\partial}{\partial x}\left(\frac{Q^{2}}{A}\right)+g \cdot A \frac{\partial y}{\partial x}=a \cdot A \cdot S_{0}-g \cdot A \cdot S_{f}
$$

Onde: $\mathrm{g}=$ aceleração da gravidade $\left(\mathrm{m} / \mathrm{s}^{2}\right)$

$\mathrm{S}_{0}=$ declividade do canal $(\mathrm{m} / \mathrm{m})$;

$\mathrm{S}_{\mathrm{f}}=$ declividade da linha de energia $(\mathrm{m} / \mathrm{m})$.

O operador pode escolher entre diferentes níveis de sofisticação para a resolução destas equações, podendo utilizar três métodos: o método do Fluxo Constante, que assume que dentre de cada passo de tempo o fluxo é constante e uniforme, o que apenas propaga o hidrograma de montante a jusante sem alteração de forma ou velocidade de propagação; o método da Onda Cinemática, que translada o hidrograma considerando atrasos na propagação e atenuação de seu pico a medida que o tempo passa; o método da Onda Dinâmica, método mais completo que faz a translação do hidrograma, considera a atenuação de seu pico e ainda os fenômenos de remanso e aceleração de fluxo.

$\mathrm{Na}$ versão 5 do programa, a possibilidade de introdução de dispositivos compensatórios nas bacias hidrográficas ampliou significativamente a aplicabilidade do modelo SWMM, principalmente com a expansão dos conceitos de drenagem 
urbana sustentável nos últimos tempos. O modelo permite a introdução de 8 tipos de dispositivos: células de bioretenção, jardins de chuva, telhados verdes, trincheiras de infiltração, pavimentos permeáveis, microreservatórios (cisternas), desconexão telhado-calha e valas vegetadas.

A representação de todas as técnicas compensatórias ocorre no modelo SWMM através da combinação de 5 camadas horizontais, e cada técnica utiliza uma combinação de camadas. As diferentes camadas possíveis de um controle LID no SWMM são:

- Superfície: terreno superficial que recebe a precipitação ou escoamento afluente de outras áreas.

- Pavimento: camada de pavimento poroso ou material de preenchimento.

- Solo: camada de solo no qual cresce vegetação em dispositivos como telhados verdes ou jardins de chuva.

- Armazenamento: camada de material granular (brita, seixos ou cascalho, por exemplo) utilizado para armazenar a água infiltrada em dispositivos como trincheiras de infiltração. Em cisternas esta camada representa a própria cisterna.

- Dreno: dreno dos dispositivos que possuem camada de armazenamento, e representa a saída de água do dispositivo para o sistema de drenagem existente.

Nas simulações, o desempenho de cada controle LID é refletido nos componentes de balanço hídrico das bacias. Além disso, em cada simulação o programa calcula o balanço hídrico de cada camada e pode fornecer, ao final da simulação, um resumo do desempenho individual de cada tipo de controle utilizado em uma sub-bacia com vazões afluentes e efluentes, infiltração, evaporação, água drenada e armazenamento inicial e final de água. A Figura 11 representa um pavimento permeável com 5 camadas de controles LID na disposição utilizada pelo SWMM e as interações entre camadas através da troca de água. 


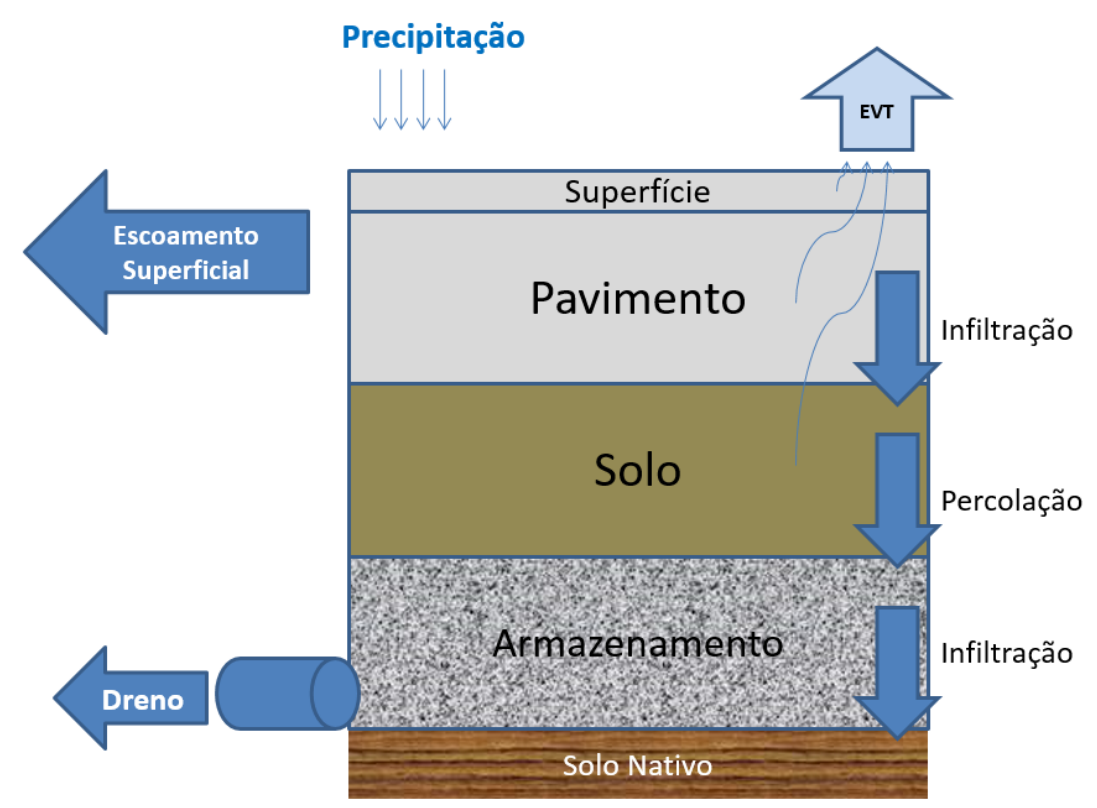

Figura 11 - Representação de Pavimento permeável por camadas e interação entre as camadas existentes

Cada uma das 5 camadas possui seus próprios parâmetros como espessura da camada, porosidade de solo ou do material granular, condutividade hidráulica, diâmetro de dreno etc. As camadas utilizadas por cada técnica compensatória podem ser vistas na Tabela 1.

Tabela 1 - Controles LID e camadas de representação obrigatórias (X) e opcionais (O) de cada um

\begin{tabular}{|c|c|c|c|c|c|}
\hline Controle LID & Superfície & Pavimento & Solo & Armazenamento & Dreno \\
\hline Células de bioretenção & $\mathrm{X}$ & $\mathrm{X}$ & $\mathrm{X}$ & $\mathrm{O}$ \\
\hline Jardins de chuva & $\mathrm{X}$ & $\mathrm{X}$ & & \\
\hline Telhados verdes & $\mathrm{X}$ & $\mathrm{X}$ & & $\mathrm{X}$ \\
\hline Trincheiras de infiltração & $\mathrm{X}$ & & & $\mathrm{X}$ & $\mathrm{O}$ \\
\hline Pavimentos permeáveis & $\mathrm{X}$ & $\mathrm{X}$ & $\mathrm{O}$ & $\mathrm{X}$ & $\mathrm{O}$ \\
\hline $\begin{array}{c}\text { Cisternas } \\
\text { Desconexão telhado- } \\
\text { calha }\end{array}$ & $\mathrm{X}$ & & $\mathrm{X}$ & $\mathrm{X}$ \\
\hline Valas vegetadas & $\mathrm{X}$ & & & $\mathrm{X}$ \\
\hline
\end{tabular}

O modelo SWMM vem sendo bastante utilizado desde seu lançamento, em 1971, até os dias atuais, e vem recebido atualizações e melhorias ao longo do tempo. As versões subsequentes foram a versão 2, de 1975, a versão 3, de 1981, e a versão 4, que, apesar de lançada em 1988, ainda é empregada em estudos atuais como em Chow et al. (2012) e Wang e Altunkaynak (2012), o que pode ser explicado pela 
linguagem computacional utilizada pelo modelo, a FORTRAN, que possibilita a integração do modelo com outros softwares.

Extensa bibliografia tem sido publicada utilizando o SWMM como ferramenta para simulações hidrológicas simples ou para simulação dos efeitos de medidas compensatórias e desenvolvimento urbano de baixo impacto. Quanto à aplicabilidade do modelo SWMM em ambientes urbanos e criação de cenários diversos, Jang et al. (2007) avaliaram o modelo SWMM para uma simulação de condições pré e pós desenvolvimento urbano, e concluíram que o modelo é bastante aplicável e apresenta melhores resultados que os tradicionais hidrogramas sintéticos utilizados isoladamente, embora tenham feito ressalvas quanto à utilização do modelo para condições pré-desenvolvimento.

Neste sentido, alguns pesquisadores compararam o modelo SWMM com outros modelos na representação de bacias na transformação chuva-vazão e também com o uso de técnicas compensatórias. Wang e Altunkaynak (2012) compararam simulações chuva-vazão entre o SWMM, uma abordagem por lógica fuzzy e dados reais medidos, e apontam que ambos produzem bons resultados, mas o primeiro é mais versátil e que, por possuir ferramentas de calibração, produz resultados mais completos com boa correlação entre hidrogramas simulados e hidrogramas observados. Elliot e Trowsdale (2007) revisaram diversos modelos utilizados para simulações hidrológicas em áreas urbanas e concluíram que o SWMM é bastante apropriado para modelagem chuva-vazão, planejamento de uso e ocupação do solo e dimensionamento preliminar de técnicas compensatórias, bem como o efeito combinado de determinado uso e ocupação do solo e técnicas compensatórias. Entretanto, os autores alertam para a complexidade do modelo com excesso de parâmetros e necessidade de base de dados espacial confiável para obtenção destes parâmetros.

Com relação à utilização de técnicas compensatórias em simulações, Lucas (2010) simulou a aplicação de estruturas de bio-infiltração em ambiente urbano utilizando o modelo SWMM com séries continuas de precipitações em comparação com outro modelo, o HydroCAD (www.hydrocad.net), funcionando com eventos pontuais. $O$ autor concluiu que o software é apropriado para simulações do tipo chuvavazão com técnicas compensatórias e que estruturas deste tipo podem facilmente ser representadas com as ferramentas do modelo. 
Apesar de apropriado para o uso pretendido neste trabalho, os resultados obtidos com o modelo dependem muito do usuário e da representação da bacia hidrográfica. Tikkanen (2013) estudou, sem calibração, níveis diferentes de detalhamento de bacias no SWMM, e concluiu que o software é adequado para uso em pequenas e grandes bacias e que, quanto maior o detalhamento, bem como maior acurácia espacial na simulação, melhores os resultados de simulação. $O$ autor ainda enfatiza a importância de utilização paralela de material cartográfico associado com SIG para a parametrização das bacias, mas faz ressalvas quanto à excessiva parametrização do modelo, o que exige extenso trabalho manual na geração e inserção de dados das bacias no SWMM.

Desde a inserção do módulo de técnicas compensatórias, chamadas no modelo de controles LID, diversos pesquisadores têm utilizado o modelo SWMM para prever seus os efeitos no escoamento superficial em quantidade e qualidade. Shin et al. (2013) analisaram, utilizando o SWMM, a redução de escoamento superficial através da simulação de cenários com telhados verdes e pavimentos permeáveis em comparação a um cenário real e conseguiram redução de cerca de $15 \%$ no volume total de escoamento através do uso moderado das técnicas compensatórias. Qin, Li e Fu (2013) utilizaram o SMWM, calibrado com dados reais, para comparar o desempenho de telhados verdes, valas vegetadas e pavimentos permeáveis, utilizados de maneira extensiva em diferentes cenários, frente a diferentes eventos chuvosos. Seus resultados de vazão foram bastante coerentes em relação a tempo e pico de hidrogramas, e os autores concluiram que a técnica compensatória mais eficaz no controle de escoamento - em termos de área ocupada versus redução de volume - são os pavimentos permeáveis, seguido dos telhados verdes e valas vegetadas. Além disso, o desempenho de cada técnica foi testado frente a diferentes distribuições temporais de precipitação, e os autores concluíram que

Aad et al. (2010) utilizaram o modelo SWMM na simulação de cisternas residenciais e jardins de chuva no controle do escoamento superficial e concluíram que este é apropriado para antecipar resultados da aplicação das técnicas compensatórias na área de estudos, embora tenham sugerido estudos de campo mais aprofundados para a validação dos resultados obtidos na simulação. Além disso, os autores fizeram adaptações na modelagem hidrológica para jardins de chuva e microreservatórios residenciais no modelo SWMM5.0 e concluíram que o modelo comporta perfeitamente simulações deste tipo. No trabalho, relatam que os jardins de 
chuva são dispositivos bastante eficientes na redução de volume de pico e que se, mesmo com pouca área de drenagem (cerca de 15\% das áreas impermeáveis), jardins de chuva promovem redução significativa nas vazões de pico dos hidrogramas. Além disso, apontam que com os jardins de chuva ocupando apenas 3,8\% de área em relação à área dos reservatórios individuais, sua redução de volume escoado foi de $35 \%$ em relação aos reservatórios.

Concluindo, Ahiablame et al. (2012), após considerável revisão bibliográfica, afirmam que o modelo SWMM pode ser usado com precisão para avaliar processos de chuva-vazão em áreas com técnicas compensatórias com resultados muito próximos aos vistos na prática.

A respeito de qualidade de água de escoamento, Li, Li e Li (2016) utilizaram o modelo SWMM com sucesso para estimar tratamento quali-quantitativo das águas pluviais utilizando jardins de chuva em áreas bastante urbanizadas de pouco mais de $1,6 \mathrm{~km}^{2}$ com considerável detalhamento da rede de microdrenagem.

O SWMM foi utilizado também para alguns estudos que analisaram o a influência do posicionamento das técnicas compensatórias e seus efeitos no controle do escoamento. Zhang et al. (2013) propõem metodologia para modelagem de estruturas de bioretenção no SWMM e afirmam que a posição e distribuição das estruturas ao longo da bacia influenciam na redução do escoamento. Os autores propuseram uma metodologia de otimização multi-objetivo das mesmas na área de estudos e validaram o resultado através do modelo SWMM.

Com relação à combinação dos efeitos de técnicas compensatórios e posicionamento das mesmas, Miguez et al. (2009) avaliaram os efeitos da combinação de várias medidas de controle de inundação em uma bacia por modelação matemática, após calibração, e concluíram que a distribuição das medidas ao longo de toda a bacia é muito importante para controle de inundações, concluindo também que até algumas técnicas utilizadas na abordagem higienista podem ajudar em determinados momentos. 
Avaliação do potencial de aplicação de técnicas compensatórias em áreas urbanas consolidadas 


\section{MATERIAL E MÉTODOS}

Neste capítulo são apresentados os materiais e métodos utilizados para a realização deste trabalho. $O$ trabalho tem duas etapas bem definidas: uma primeira utilizando SIG e sensoriamento remoto para obtenção de dados hidrológicos da bacia e criação de mapas de adequabilidade à implantação de técnicas compensatórias e uma segunda etapa, na qual os dispositivos foram dimensionados, quantificados e tiveram seu desempenho avaliado por simulação hidrológica através de cenários hipotéticos.

\section{1 ÁREA DE ESTUDOS}

O estudo de caso deste trabalho se dá na bacia hidrográfica do Córrego do Gregório, uma bacia dentro da área urbana do município de São Carlos/SP que possui grande parte de sua área densamente urbanizada e algumas parcelas ainda rurais. Segundo o Plano Estadual de Recursos Hídricos (DAAE, 2006), o Estado de São Paulo está dividido em 22 unidades de gestão de recursos hídricos (UGRHI). A subbacia do córrego Monjolinho, onde está inserido o córrego do Gregório, faz parte da UGRHI 13 (Bacia Tietê/Jacaré), a qual se encontra em crescente processo de urbanização e possui parcelas urbanas e rurais. A bacia do córrego do Gregório tem aproximadamente $18,9 \mathrm{~km}^{2}$ e perímetro de $22,4 \mathrm{~km}$, com nascente a leste da cidade. O córrego corre no sentido oeste em uma extensão aproximada de $8,6 \mathrm{~km}$ até desembocar no córrego Monjolinho. Quanto à pedologia, São Carlos é caracterizada por solos altamente permeáveis, em sua maioria, constituídos por zonas de latossolovermelho-amarelo e de areia quartzosa profunda com característica arenosa, tipos também do solo da bacia hidrográfica do córrego do Gregório. A bacia hidrográfica do córrego do Gregório é apresentada na Figura 12. 


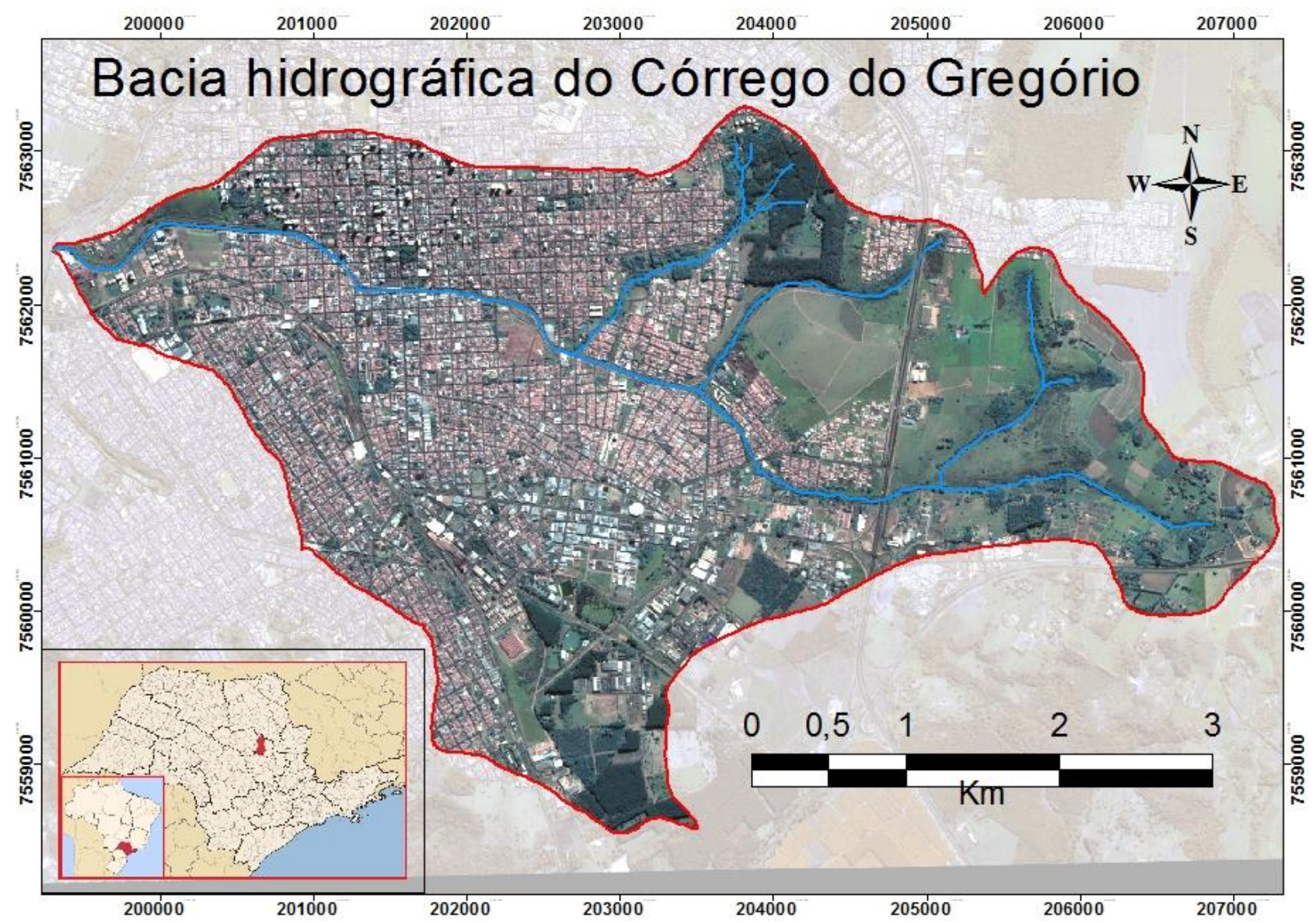

Figura 12 - Bacia hidrográfica do Córrego do Gregório

A bacia do córrego do Gregório foi escolhida para o estudo de caso por apresentar diversas formas de ocupação em sua área. A área leste da bacia apresenta ocupação rural, com áreas de pastagem, pequenas porções de mata densa e culturas perenes como goiaba e laranja. A área central apresenta ocupação residencial, industrial e comercial, ainda com algumas porções de áreas abertas e permeáveis. A área oeste da bacia apresenta ocupação bastante densa (área central da cidade de São Carlos), grande percentual de impermeabilização e ocorrências frequentes de inundações.

A bacia do córrego do Gregório é alvo de estudos de caráter hidrológico há muitos anos pelas universidades existentes em São Carlos, dentre os quais pode-se citar Machado (1981), Barbassa (1991), Oliveira (1999), Almeida Neto et al. (2004), Alves (2005), Boldrin (2005), Ribeiro e Mendiondo (2007), Barros (2008), Alvarez (2010), Graciosa (2010), Decina (2012), Martins (2012), Abreu (2013), Almeida (2013) e Shinma (2015). A grande quantidade de trabalhos realizados nesta bacia facilita a pesquisa e fornece dados preciosos que serão utilizados, em maioria, como referências aos valores levantados para a rede hidráulica e hidrológica da bacia. 


\subsubsection{PDDUAS da bacia do Gregório}

A cidade de São Carlos possui um Plano Diretor de Drenagem Urbana Ambientalmente Sustentável (PDDUAS) desde 2011 (PMSC, 2011). Neste documento, estão contidos subsídios técnicos e o planejamento da expansão urbana para auxiliar o poder público a solucionar os problemas relacionados à drenagem urbana na cidade. Além disso, o PDDUAS propõe uma série de medidas estruturais e não estruturais a serem implementadas na cidade para mitigação dos frequentes problemas de drenagem urbana que esta enfrenta.

Dentre as medidas estruturais encontram-se 21 barramentos a serem implantados no perímetro peri-urbano da cidade onde funcionariam como reservatórios de retenção ou detenção, visando o amortecimento das vazões de pico das ondas de cheia urbana. Foram planejados barramentos in-line para os córregos do Douradinho, Ponte de Tábua, Monjolinho, Santa Maria Madalena, Tijuco Preto, Paraíso, Mineirinho, Gregório, Sorregotti, Lazzarini, Medeiros, Água Quente e Água Fria e reservatórios off-line para o córrego do Monjolinho. Ademais, estão previstas canalizações em trechos dos córregos do Gregório e Monjolinho, entre outras estruturas como escadas hidráulicas e aterros hidráulicos. A localização das medidas estruturais pode ser visualizada no Anexo 21 do PDDUAS (PMSC, 2011a).

Com relação a outras técnicas compensatórias, destaca-se que o manual de drenagem urbana apresentado no PDDUAS informa e orienta sobre o funcionamento e a utilização de técnicas de redução de escoamento como controle na fonte através de poços de infiltração, telhados verdes, bacias de percolação, valas de infiltração, dentre outros dispositivos. Entretanto, exceto pelos reservatórios de detenção, não foram apresentadas propostas de implantação de tais dispositivos na cidade de São Carlos. O que se encontra é a sugestão ao poder público para que lotes que adotem técnicas de redução de escoamento sejam alvo de incentivo e, para casos em que haja o aumento do escoamento pela ausência de tais dispositivos, sejam adotadas penalidades.

Especificamente para a bacia do Gregório, oito medidas estruturais foram planejadas no PDDUAS, dentre as quais 5 são bacias de detenção e 3 são alterações na calha dos córregos. A localização das medidas estruturais previstas na área de estudos é apresentada na Figura 13 e as medidas são identificadas na Tabela 2. 


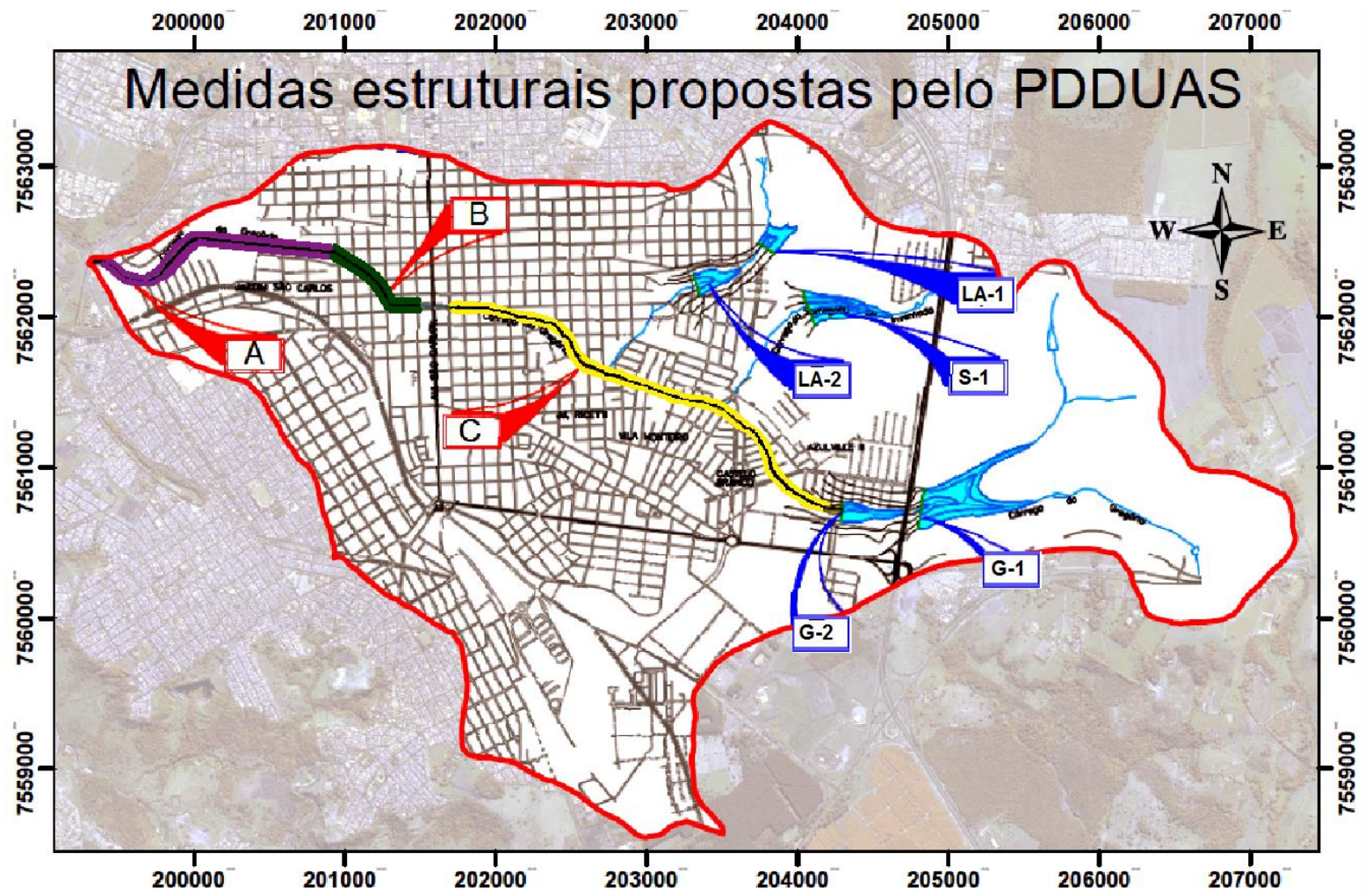

Figura 13 - Localização das medidas estruturais na bacia do Gregório (adaptado de PMSC, 2011)

Tabela 2 - Identificação das medidas estruturais na bacia do córrego do Gregório

\section{Legenda Medida estrutural}

A Regularização de canal com concreto armado no córrego do Gregório

B Regularização de canal com concreto armado no córrego do Gregório

C Regularização de canal com concreto armado no córrego do Gregório

LA-1 Barramento para reservatório de detenção in-line no córrego Lazarini

LA-2 Barramento para reservatório de detenção in-line no córrego Lazarini

G-1 Barramento para reservatório de detenção in-line no córrego do Gregório

G-2 Barramento para reservatório de detenção in-line no córrego do Gregório

S-1 Barramento para reservatório de detenção in-line no córrego Sorregotti

As medidas estruturais previstas pelo plano diretor fazem parte dos cenários propostos na etapa de simulação hidrológica da bacia conforme propostos no PDDUAS e são abordados em capítulos subsequentes. 


\subsection{MATERIAIS UTILIZADOS}

Para a realização deste trabalho, foram utilizados diversos materiais cartográficos, bem como dados de diversas naturezas obtidos em trabalhos científicos e manuais técnicos.

Inicialmente, para trabalhos que envolveram sensoriamento remoto, foi utilizada uma imagem de satélite de alta resolução espacial da área urbana de São Carlos, capturada em 11 de junho de 2011 pelo satélite WorldView-2. A imagem possui resolução espacial de $0,52 \mathrm{~m}$ na banda pancromática e oito bandas espectrais (vermelho, verde, azul, infravermelho próximo, azul costal, amarela e red-edge) com resolução espacial de 2,4m. A imagem cobre toda a área de estudos e fornece informações importantes sobre a distribuição espacial da malha urbana sobre a bacia do Gregório.

Para trabalhos referentes à topografia da área de estudos foi utilizado um modelo digital de elevação (MDE) obtido via internet a partir de um levantamento da Embrapa (MIRANDA, 2012), bem como um documento em formato CAD, escala 1:10.000, obtido no CDCC (Centro de Divulgação Científica e Cultural), da USP São Carlos, que contém várias informações como curvas de nível (a cada 5 metros), arruamento e delimitação de bacias hidrográficas da cidade de São Carlos. Para levantamento do mapa potenciométrico foi utilizado um levantamento do nível do lençol freático de diversos pontos da cidade realizado por Bartolomeu (2012). O mapa foi elaborado em ambiente SIG (Sistemas de Informações Geográficas) a partir do cruzamento de dados pontuais de nível de lençol freático e da localização das nascentes de córregos na bacia hidrográfica.

Para informações referentes à pedologia, capacidade de infiltração e outros parâmetros hidrológicos relativos ao tipo de solo, foi utilizado um mapa pedológico do município de São Carlos proveniente do PDDUAS, adaptado do documento "Levantamento pedológico semi-detalhado da quadrícula de São Carlos, EMBRAPA/IAC, 1981", originalmente um material em escala 1:100.000.

Em relação a programas computacionais (softwares) utilizados na realização do trabalho, os principais foram o software ArcGIS10. ${ }^{\circledR}$, uma interface SIG, usada no levantamento de informações e dados a partir de material cartográfico, produção de 
mapas e novos materiais cartográficos, gerenciamento de informações espaciais e geoprocessamento de dados.

Para trabalhos de processamento digital da imagem de satélite, foi utilizado o software Definiens Developer $8.0^{\circledR}$, especializado na técnica de Análise Orientada a Objetos (AOO), utilizado para a obtenção de parâmetros hidrológicos relacionados ao uso e ocupação do solo. Para a realização da modelagem hidrológica, optou-se pelo uso do software SWMM 5.0, que possui um módulo de simulação de técnicas compensatórias e permite realizar o tipo de simulação pretendido no trabalho. Ademais, outros materiais que por ventura tenham sido utilizados serão citados ao longo no corpo do trabalho.

\subsection{CLASSIFICAÇÃO DO USO E OCUPAÇÃO DO SOLO DA BACIA}

Para a construção de um modelo hidrológico de representação da bacia hidrográfica, vários parâmetros foram levantados através de sensoriamento remoto. Os parâmetros referentes ao uso e ocupação do solo na bacia foram obtidos através do processamento digital da imagem de satélite da área de estudos. Para tanto, foi utilizado o software Definiens Developer para a aplicação de uma técnica denominada Análise Orientada a Objetos (AOO), que faz a classificação de imagens de forma automática supervisionada, ou seja, classifica de forma automática a partir da prédeterminação de classes e pela seleção de diversas amostras pelo operador.

O processo de AOO inicia-se pela definição prévia das classes de uso de solo. Uma vez que o processo de classificação teve por objetivo fornecer informações para quantificação do escoamento superficial através do método CN-NRCS, a escolha de classes ocorreu utilizando classes que pudessem ser distinguíveis na imagem e tivessem comportamento hidrológico bem conhecido. Assim, as classes escolhidas foram telhado, cinza (asfalto, concreto e superfícies metálicas), cultura perene, vegetação rasteira, vegetação arbórea, agricultura, solo e sombras. Uma vez que os tipos de coberturas de solo em uma área urbana superam consideravelmente estes oito tipos escolhidos, vários objetos foram agrupados dentro de uma classe baseandose na refletância dos objetos (a fim de facilitar o agrupamento pelo software) e na resposta hidrológica das superfícies.

Assim, os objetos enquadrados dentro de cada classe bem como exemplos dos objetos representados na imagem de satélite são apresentados na Tabela 3. 
Tabela 3 - Classes de cobertura de solo e objetos enquadrados em cada classe

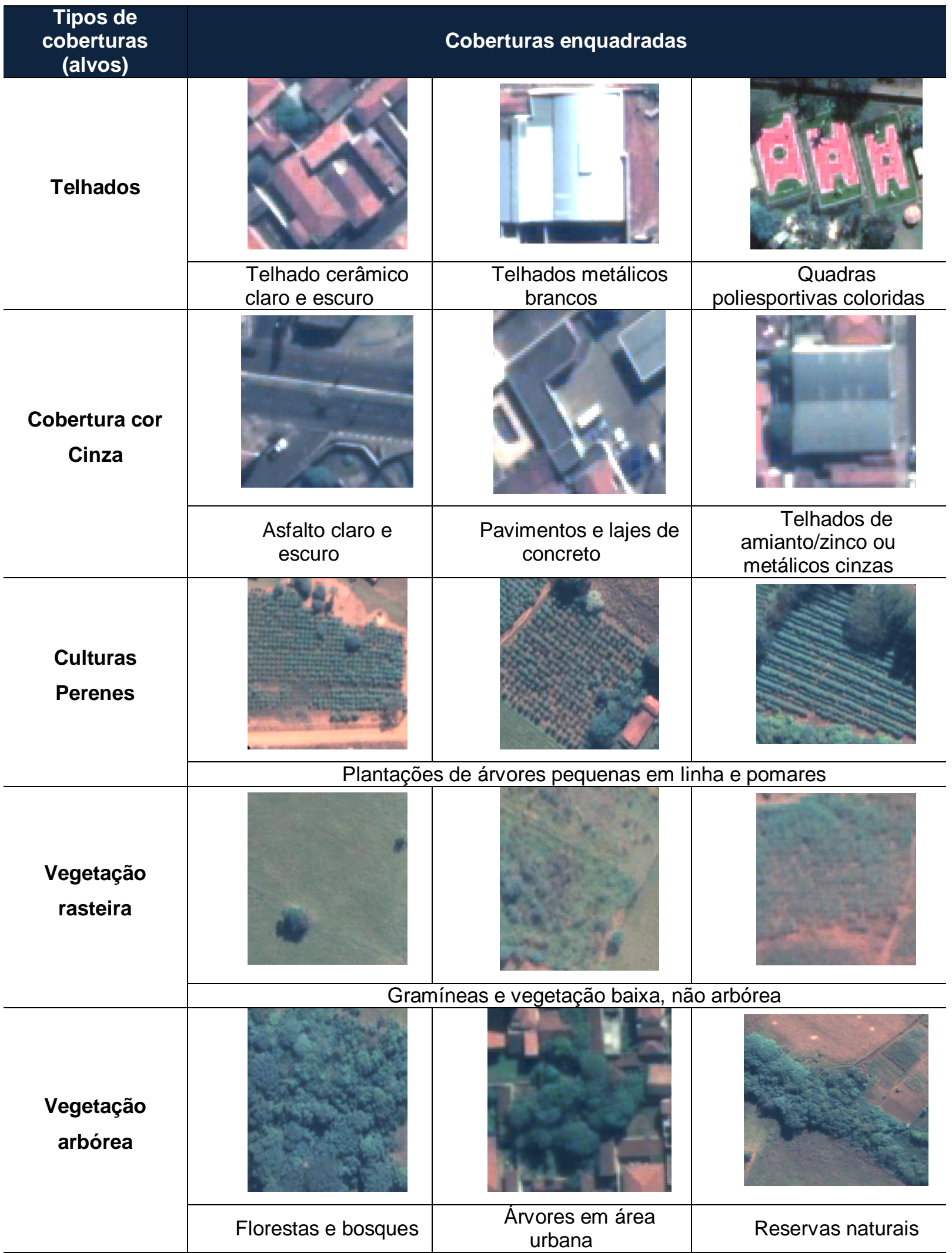




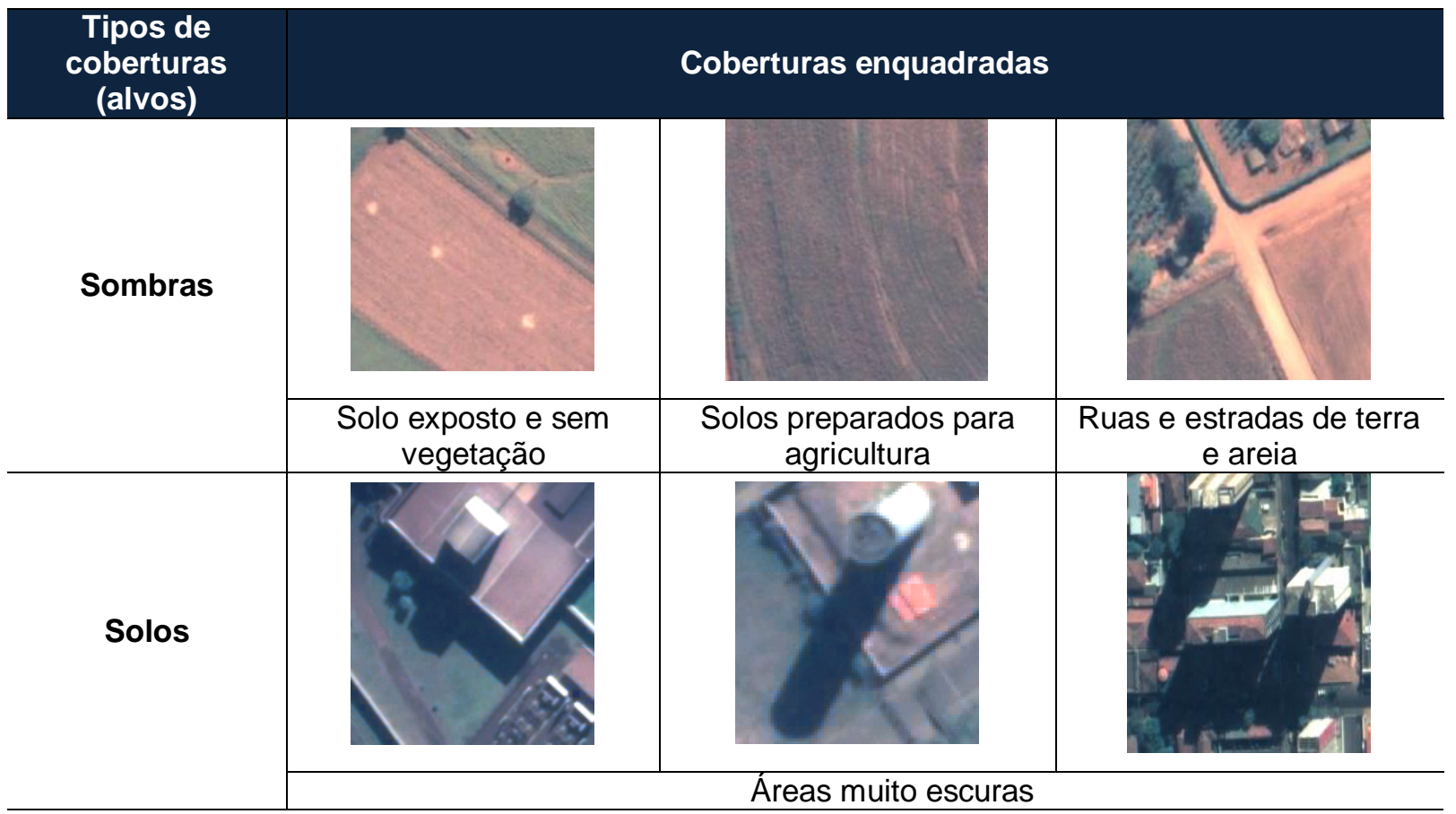

A partir do resultado da classificação da imagem de satélite, além de dados como grau de impermeabilização da bacia, foi possível calcular o Curve-Number da bacia hidrográfica a partir das tabelas do método NRCS (TR-55) e, para isso, cada classe recebeu um CN próprio. Sendo os solos predominantes do tipo B, na Tabela 4 são apresentados os CN adotado para cada classe individual, destacando-se a classe sombras que, pela impossibilidade de se determinar o tipo de objeto que cobriam, não recebeu $\mathrm{CN}$ e foi desconsiderada durante os cálculos através da desconsideração de sua área na área total das sub-bacias.

Tabela 4 - Curve Number das coberturas classificadas no trabalho

\begin{tabular}{|cc|}
\hline Tipos de coberturas (alvos) & Valores de CN \\
\hline Telhados & 98 \\
\hline Cobertura cor Cinza & 98 \\
\hline Culturas perenes & 78 \\
\hline Vegetação rasteira & 69 \\
Vegetação arbórea & 55 \\
\hline Solos & 82 \\
\hline Sombras & - \\
\hline
\end{tabular}




\subsection{PARÂMETROS HIDROLÓGICOS BÁSICOS DA BACIA}

Durante os processos de simulação hidrológica, diversas informações e dados da bacia hidrográfica do córrego do Gregório foram utilizados. A maioria destes foram levantados através de SIG e do material cartográfico já citado. O divisor de águas utilizado foi obtido no material do CDCC e, sobreposto ao MDE da Embrapa e alguns outros dados de relevo, mostrou-se bastante coerente. A divisão de sub-bacias foi adaptada de Martins (2012) para que se adicionasse mais uma sub-bacia, dividindo assim a sub-bacia originalmente denominada "sub-bacia 10" nas sub-bacias $10.1 \mathrm{e}$ 10.2. O traçado foi feito manualmente baseado nas curvas de nível do próprio material do CDCC que, além da já citada delimitação da bacia completa, possui a maior resolução de dados de relevo dentre todos os materiais usados. Destes materiais foram obtidos ainda a declividade média da superfície das sub-bacias, sua área, comprimento de talvegue, entre outras características físicas das sub-bacias hidrográficas.

\subsection{ADEQUABILIDADE DA IMPLANTAÇÃO DE TÉCNICAS COMPENSATÓRIAS}

Para criação de cenários hipotéticos de utilização de técnicas compensatórias na bacia do Gregório e, diante da necessidade de se alocar e quantificar estas técnicas compensatórias durante este processo, foi preciso que se avaliasse a área de estudos, segundo critérios técnicos, para reconhecimento dos locais aptos a receberem os dispositivos. Para que fosse exequível, o processo teve de ser conduzido com informações válidas e critérios técnicos igualmente válidos, de modo que os cenários hipotéticos fossem representativos e expusessem com fidelidade o potencial de implantação de técnicas compensatórias na área de estudos. Somente desta forma seria possível avaliar qual o grau de impacto que se conseguiria atingir, nos hidrogramas da bacia, aplicando-se os princípios da drenagem sustentável através do uso de medidas estruturais - em uma região já urbanizada.

Para a alocação das técnicas compensatórias, optou-se pelo reconhecimento de todas as áreas teoricamente aptas a receberem os dispositivos compensatórios, e posteriormente, durante a criação dos cenários, a quantificação dos dispositivos ocorreu baseando-se nestas informações. Buscando-se o reconhecimento das áreas 
adequadas à implantação de técnicas compensatórias na bacia do Gregório, utilizouse uma técnica denominada de álgebra de mapas para a criação de "mapas de adequabilidade".

Para o planejamento do processo de álgebra de mapas foi necessária uma considerável revisão de literatura em livros, manuais e recomendações técnicas para que fossem investigados quais parâmetros físicos da área de implantação influenciam na eleição de determinada técnica compensatória, bem como quais os valores destes parâmetros seriam adequados.

Embora existam inúmeros manuais e recomendações técnicas a respeito de dispositivos compensatórios e sua implantação, poucos são aqueles que apresentam recomendações técnicas como declividades adequadas para a implantação, uso e ocupação do solo restritivos, profundidades adequadas de lençol freático e aspectos construtivos importantes para sua construção. Desta forma, foram adotados como referências apenas aqueles que apresentassem recomendações mais detalhadas, mesmo que em poucos aspectos. Visto isso, os materiais escolhidos foram os nacionais Manual de Drenagem e Manejo de Águas Pluviais de São Paulo (SÃO PAULO, 2012), o Manual de Drenagem Urbana de Porto Alegre (PORTO ALEGRE, 2005) e as Cartilhas Técnicas da Fundação Centro Tecnológico de Hidráulica (FCTH, n.d.) e, como materiais internacionais, foram escolhidos o Storm Water BMP Guide (EUA, manual do estado do Havaí; HONOLULU, 2012), o Portland Stormwater Management Manual (EUA, manual do estado de Portland; PORTLAND, 2008), Development Best Management Practices Handbook (EUA, manual da cidade de Los Angeles; LOS ANGELES, 2011), o LID Technical Guidance Manual for Puget Sound (EUA, distrito de Washington; PSP, 2012), o Eastern Washington LID Guidance (EUA, distrito de Wahington; WASHINGTON, 2013), o Urban Storm Drainage Criteria Manual (EUA, estado do Colorado; UDFCD, 2010), o The SUDs Manual (Reino Unido; WOODS-BALLARD et al. 2007) e o WSUD Measures and Aplications (Austrália; URS, 2004).

Ao longo do levantamento, ficou evidente que os manuais dos Estados Unidos da América são os que mais apresentam critérios técnicos para a implantação das técnicas compensatórias, o que revela uma padronização maior do estilo de implantação e construção das técnicas neste país, embora as diretrizes possam varia consideravelmente de estado para estado. Escolhidos os manuais que guiariam o processo de reconhecimento da área de estudos quanto à adequabilidade à 
implantação de técnicas compensatórias, foi preciso que se escolhesse quais técnicas seriam utilizadas no trabalho, uma vez que a variedade destes dispositivos em manuais é imensa.

A escolha das técnicas compensatórias utilizadas neste trabalho baseou-se em duas razões principais, a primeira diz respeito ao objetivo de sua utilização, que é o controle quantitativo do escoamento superficial; a segunda razão é a possibilidade de simulação com o software escolhido, e o SWMM5.0 permite a simulação de 8 técnicas compensatórias: células de bioretenção, jardins de chuva, telhados verdes, trincheiras de infiltração, pavimentos permeáveis, microreservatórios individuais (também chamados de cisternas ou barris de chuva), desconexão da calha pluvial e valas vegetadas.

Conforme apresentado em capítulos anteriores, no modelo SWMM, os dispositivos podem utilizar cinco camadas para controle do escoamento, dentre as quais duas tem maior capacidade de combater o escoamento, que são as camadas de solo e camada de armazenamento. Das oito técnicas compensatórias, sete possuem uma destas duas camadas: células de bioretenção, jardins de chuva, telhados verdes, trincheiras de infiltração, pavimentos permeáveis e microreservatórios. Além disso, vale citar que, dentro do modelo SWMM, as células de bioretenção e os jardins de chuva podem ser considerados praticamente a mesma técnica, com a diferença que as células de bioretenção possuem uma camada de solo e uma camada de armazenamento com material granular, enquanto os jardins de chuva possuem apenas a camada de solo. Assim, neste ponto, optou-se por utilizar como jardins de chuva os dispositivos descritos como células de bioretenção pelo modelo SWMM, uma vez que a camada de armazenamento permite que sejam mais eficientes no controle do escoamento superficial.

Além disso, optou-se por não se utilizar a técnica compensatória chamada de desconexão da calha pluvial por se entender que, além de pouco eficiente no controle de escoamento pluvial, muitos manuais não a consideram uma técnica compensatória. Desta forma, foram analisados nos manuais os seguintes dispositivos: Pavimento Permeável, Jardins de Chuva, Telhados Verdes, Valas Vegetadas, Trincheiras de Infiltração Lineares e Microreservatórios. Estes dispositivos, somados às bacias de detenção, seriam as técnicas compensatórias avaliadas neste trabalho. 
Os quadros (Quadros 1, 2, 3, 4, 5 e 6) com as informações levantadas para cada técnica nos manuais escolhidos são apresentados a seguir. 
Quadro 1 - Diretrizes técnicas de diferentes manuais para implantação de pavimentos permeáveis

Pavimento permeável

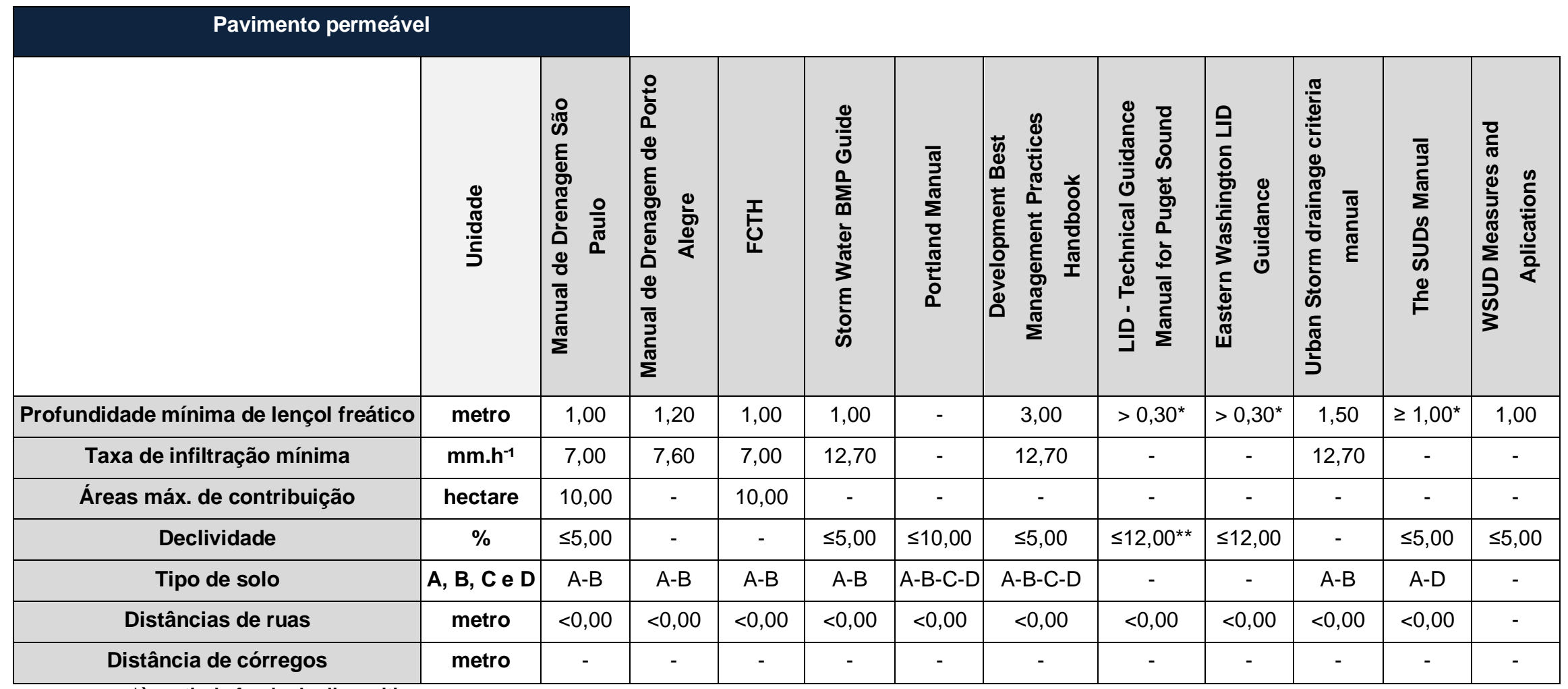

*à partir do fundo do dispositivo

${ }^{\star *}$ exceto asfalto poroso, que é $5 \%$. Acima de $3 \%$ deve-se considerar reservatórios de detenção no dispositivo 
Avaliação do potencial de aplicação de técnicas compensatórias em áreas urbanas consolidadas

Quadro 2 - Diretrizes técnicas de diferentes manuais para implantação de jardins de chuva lineares Jardins de chuva

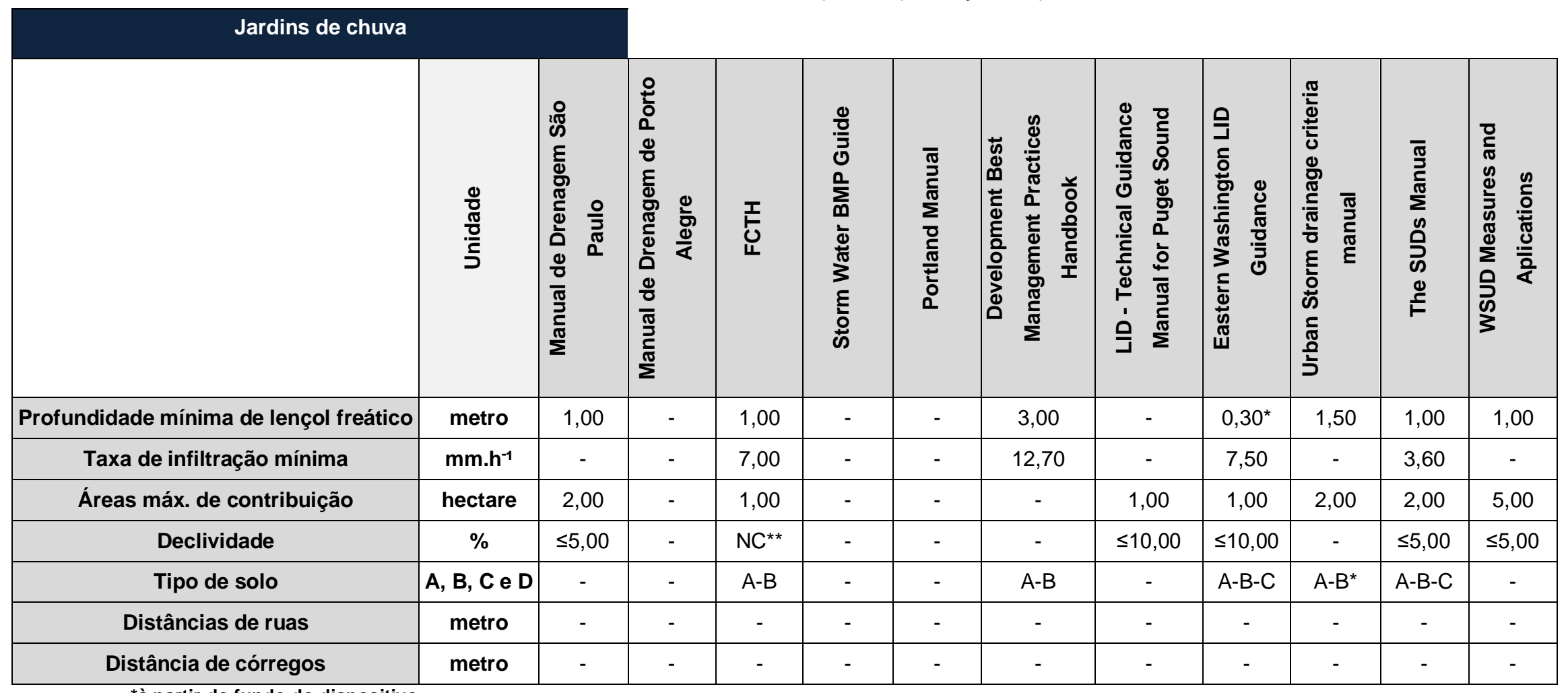

*à partir do fundo do dispositivo

**NADA CONSTA, mas faz referência à inviabilidade em altas declividades

***Permite em solos $C$ e $D$ desde que não tenham por objetivo principal a promoção da infiltração 
Quadro 3 - Diretrizes técnicas de diferentes manuais para implantação de telhados verdes Telhados verdes

\begin{tabular}{|c|c|c|c|c|c|c|c|c|c|c|c|c|}
\hline \multicolumn{13}{|l|}{ Telhados verdes } \\
\hline & $\begin{array}{l}\frac{\pi}{0} \\
\frac{\pi}{0} \\
\frac{\pi}{5} \\
5\end{array}$ & 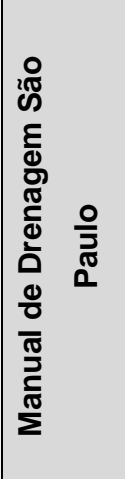 & 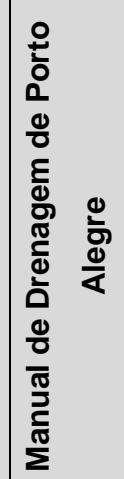 & I & 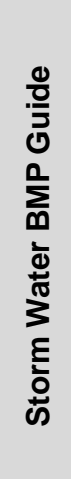 & 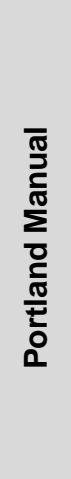 & 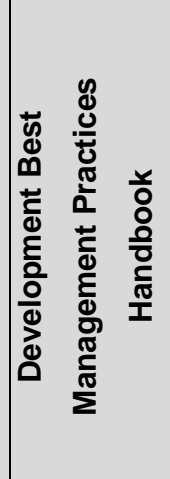 & 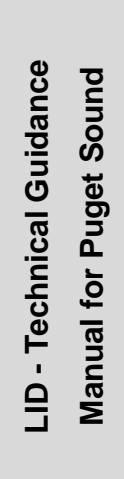 & 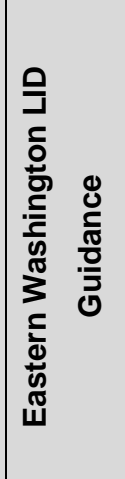 & 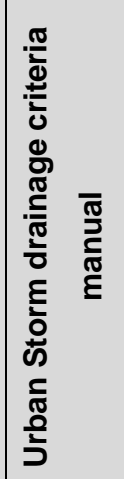 & 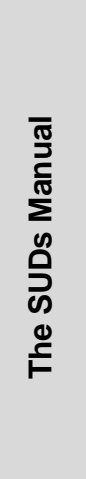 & 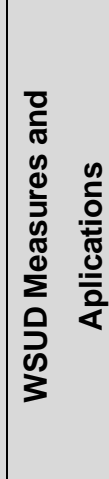 \\
\hline Profundidade mínima de lençol freático & metro & - & - & - & - & - & - & - & - & - & - & - \\
\hline Taxa de infiltração mínima & $\mathrm{mm} \cdot \mathrm{h}^{-1}$ & - & - & - & - & - & - & - & - & - & - & - \\
\hline Áreas máx. de contribuição & hectare & 2,00 & - & - & - & - & - & - & - & - & 2,00 & 2,00 \\
\hline Declividade & $\%$ & - & - & - & - & - & - & - & - & - & - & - \\
\hline Tipo de solo & A, B, C e D & - & - & - & - & - & - & - & - & - & - & - \\
\hline Distâncias de ruas & metro & - & - & - & - & - & - & - & - & - & - & - \\
\hline Distância de córregos & metro & - & - & - & - & - & - & - & - & - & - & - \\
\hline
\end{tabular}


Quadro 4 - Diretrizes técnicas de diferentes manuais para implantação de valas vegetadas

\begin{tabular}{|c|c|c|c|c|c|c|c|c|c|c|c|c|}
\hline \multicolumn{13}{|l|}{ Valas vegetadas } \\
\hline & $\begin{array}{l}\frac{\pi}{0} \\
\frac{\pi}{0} \\
5\end{array}$ & 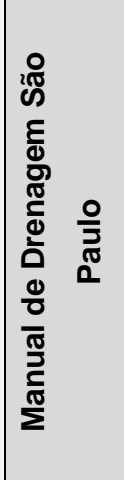 & 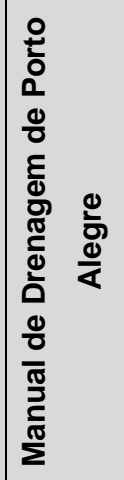 & $\underset{\mathbb{L}}{\mathbf{I}}$ & $\begin{array}{l}\frac{0}{0} \\
\bar{J} \\
0 \\
0 \\
\sum_{0} \\
\frac{1}{ \pm} \\
\frac{\pi}{\pi} \\
\Sigma \\
\frac{1}{0} \\
\dot{0}\end{array}$ & 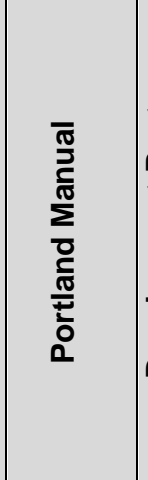 & 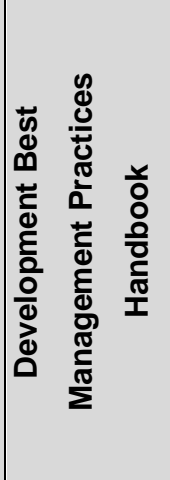 & 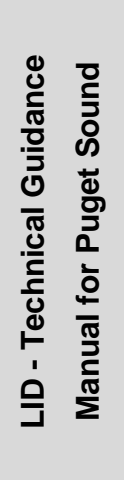 & 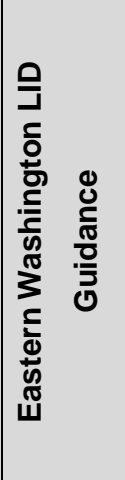 & 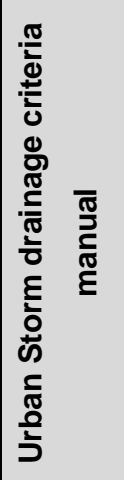 & 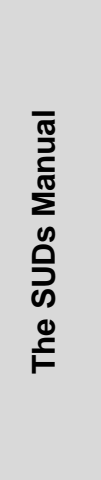 & 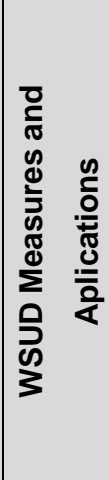 \\
\hline Profundidade mínima de lençol freático & metro & 1,00 & 1,20 & - & 1,00 & - & 3,00 & - & $0,30^{*}$ & 1,50 & $>1,00$ & 1,00 \\
\hline Taxa de infiltração mínima & $\mathrm{mm} \cdot \mathrm{h}^{-1}$ & 7,00 & 7,60 & - & 12,70 & - & 12,70 & - & 7,50 & - & - & - \\
\hline Áreas máx. de contribuição & hectare & 2,00 & - & - & - & - & - & 1,00 & 1,00 & 2,00 & 2,00 & 4,00 \\
\hline Declividade & $\%$ & $\leq 5,00$ & - & - & - & - & - & $\leq 10,00$ & - & - & $\leq 5,00$ & $\leq 5,00$ \\
\hline Tipo de solo & A, B, C e D & $A-B$ & A-B-C & - & $A-B$ & A-B-C-D & A-B & - & A-B-C & $A-B$ & $A-C$ & - \\
\hline Distâncias de ruas & metro & - & - & - & - & - & - & - & - & - & - & - \\
\hline Distância de córregos & metro & - & - & - & - & - & - & - & - & - & - & - \\
\hline
\end{tabular}

*à partir do fundo do dispositivo 
Quadro 5 - Diretrizes técnicas de diferentes manuais para implantação de trincheiras e poços de infiltração Trincheiras e poços de infiltração

\begin{tabular}{|c|c|c|c|c|c|c|c|c|c|c|c|c|c|}
\hline & $\begin{array}{l}\frac{0}{0} \\
\frac{\pi}{0} \\
\frac{0}{5}\end{array}$ & 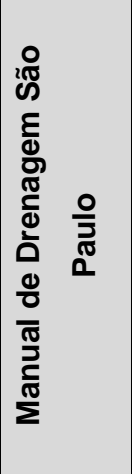 & 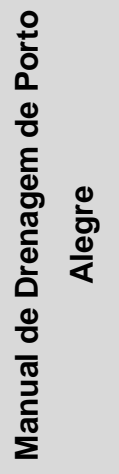 & $\underset{\mathbb{E}}{\text { I }}$ & $\begin{array}{l}\frac{0}{0} \\
\frac{0}{J} \\
0 \\
0 \\
\sum_{0} \\
\frac{1}{0} \\
\frac{ \pm}{3} \\
3 \\
\frac{5}{0} \\
\text { के }\end{array}$ & 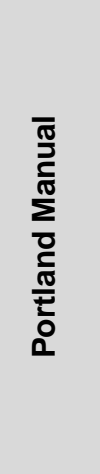 & 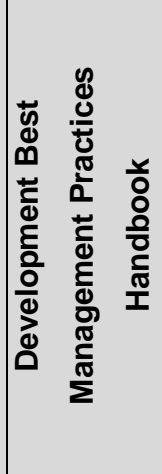 & 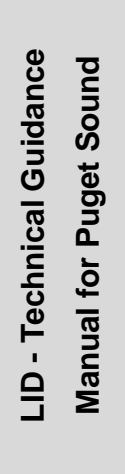 & 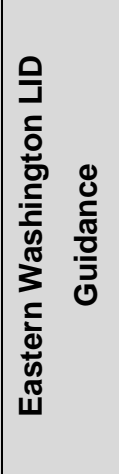 & 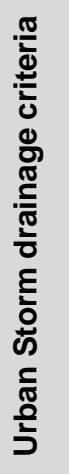 & 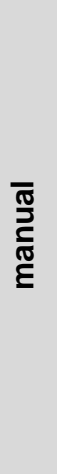 & 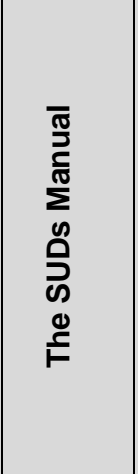 & 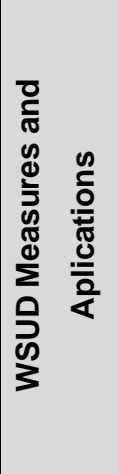 \\
\hline Profundidade mínima de lençol freático & metro & $1,00^{*}$ & $1,20^{*}$ & - & $1,00^{*}$ & $1,50^{*}$ & 3,00 & - & - & & - & $1,00^{*}$ & 1,00 \\
\hline Taxa de infiltração mínima & $\mathrm{mm} \cdot \mathrm{h}^{-1}$ & $\begin{array}{c}7,00 \text { ou } \\
4,00^{\star *}\end{array}$ & 7,60 & - & 12,70 & 12,70 & 12,70 & - & - & - & - & 3,60 & 1,30 \\
\hline Áreas máx. de contribuição & hectare & 6,00 & - & - & - & 10,00 & - & - & - & - & - & $<2,00$ & 2,00 \\
\hline Declividade & $\%$ & $\leq 5 \%$ & - & - & - & - & - & - & - & - & - & $\leq 5,00^{* * *}$ & $\leq 15,00$ \\
\hline Tipo de solo & A, B, C e D & A-B-C & A-B-C & - & $A-B$ & $A-B$ & $A-B$ & - & - & - & - & A-B-C & - \\
\hline Distâncias de ruas & metro & - & - & - & - & - & - & - & - & - & - & - & - \\
\hline Distância de córregos & metro & - & - & - & - & - & - & - & - & & - & - & - \\
\hline
\end{tabular}

*à partir do fundo do dispositivo

** maior valor para trincheiras e menor valor para poços

${ }^{* * *}$ existem valores divergentes no manual, que hora limita a $2 \%$ e hora limita a $5 \%$. 
Quadro 6 - Diretrizes técnicas de diferentes manuais para implantação de microreservatórios individuais

\begin{tabular}{|c|c|c|c|c|c|c|c|c|c|c|c|c|}
\hline \multicolumn{13}{|c|}{ Microreservatórios individuais } \\
\hline & $\begin{array}{l}\frac{\pi}{0} \\
\frac{\pi}{0} \\
5\end{array}$ & 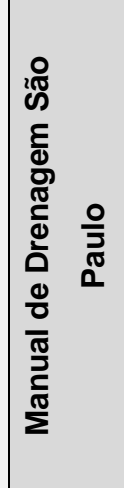 & 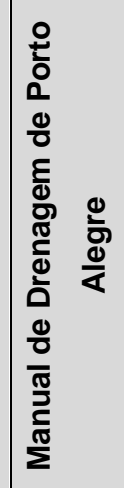 & $\underset{\mathrm{I}}{\mathrm{I}}$ & 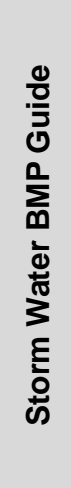 & 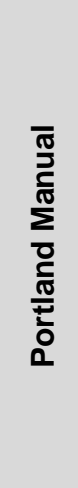 & 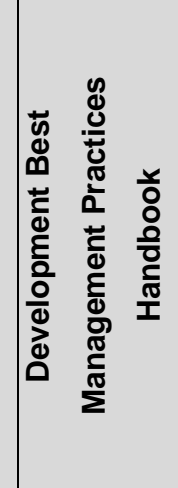 & 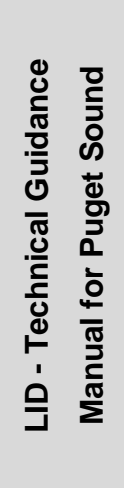 & 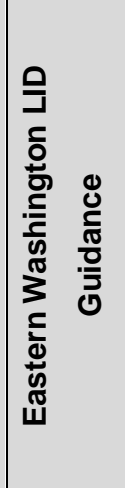 & 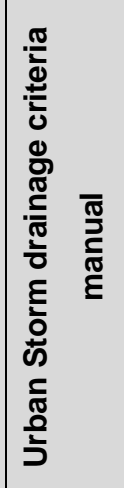 & 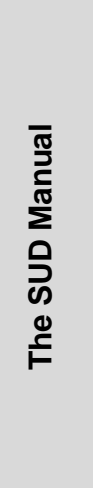 & 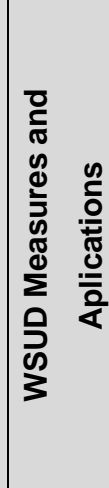 \\
\hline Profundidade mínima de lençol freático & metro & - & - & - & - & - & - & - & - & - & - & - \\
\hline Taxa de infiltração mínima & $\mathrm{mm} \cdot \mathrm{h}^{-1}$ & $7,00^{*}$ & - & - & - & - & - & - & - & - & - & - \\
\hline Áreas máx. de contribuição & hectare & 2,00 & - & - & - & - & - & - & - & - & 2,00 & 2,00 \\
\hline Declividade & $\%$ & - & - & - & - & - & - & - & - & - & - & - \\
\hline Tipo de solo & A, B, C e D & - & - & - & - & - & - & - & - & - & - & - \\
\hline Distâncias de ruas & metro & - & - & - & - & - & - & - & - & - & - & - \\
\hline Distância de córregos & metro & - & - & - & - & - & - & - & - & - & - & - \\
\hline
\end{tabular}

com infiltração total

** distância maior que $15 \mathrm{~m}$ de declividades superiores a $20 \%$ 
Todos os critérios técnicos utilizados para geração dos mapas de adequabilidade presentes neste trabalho foram obtidos após análise dos quadros apresentados. Apesar da variação nos valores apresentados pelos diferentes manuais, nota-se um mesmo padrão na existência de recomendações, como por exemplo, a limitação de construção de dispositivos de infiltração em áreas de lençol freático raso ou com solos pouco permeáveis ou a restrição de áreas de contribuição em dispositivos lineares. No caso de telhados verdes e cisternas, os manuais praticamente não impõem restrições de nenhum tipo, permitindo a implantação em praticamente qualquer local.

Neste trabalho, optou-se por utilizar, quando disponíveis, os valores apresentados pelo Manual de Drenagem e Manejo de Águas Pluviais de São Paulo que, além da vantagem da localidade - próximo geograficamente à área de estudos, no mesmo estado da federação e no mesmo país - mostrou-se o mais completo e com o maior número de referências e valores para a implantação das técnicas compensatórias o que, além de facilitar criação dos mapas, facilita a tomada de decisão dos profissionais que o utilizam. Para técnicas compensatórias que não abordadas ou que não receberam valores de referência no manual da PMSP, foram apresentaos valores retirados de outros manuais e serão citados mais adiante.

\subsection{CAMADAS DA ÁLGEBRA DE MAPAS}

A metodologia de produção de mapas de adequabilidade à implantação de técnicas compensatórias utilizou a técnica de álgebra de mapas, na qual se trabalha com diversas camadas de mapas para uma mesma área de estudos. Para cada camada, diferentes valores são atribuídos a diferentes porções do mapa de maneira que estes sejam representados por matrizes numéricas. Desta forma, é possível que se utilize princípios e operações de álgebra entre os valores dos mapas considerando as características espaciais da área de estudos para a produção de uma matriz resultante na forma de um mapa, conforme exemplificado na Figura 14. 


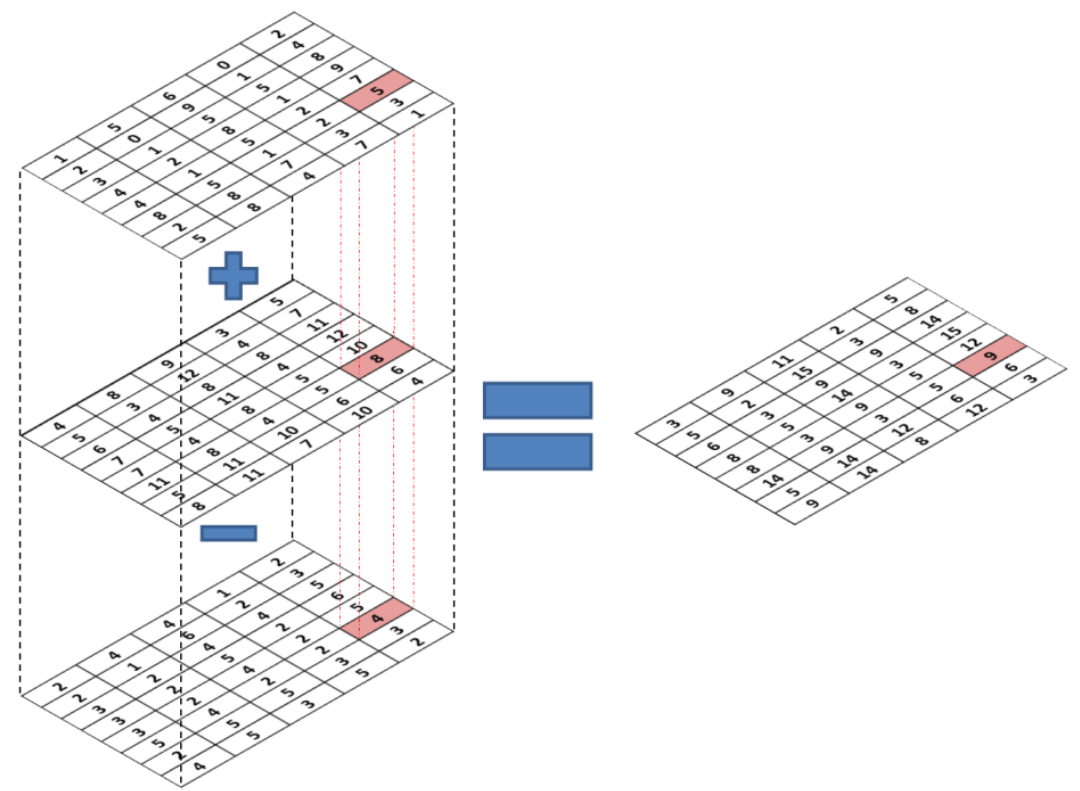

Figura 14 - Exemplo de álgebra de mapas com matrizes numéricas

Ao todo foram usadas 7 camadas no processo de verificação de adequabilidade de instalação das técnicas compensatórias avaliadas neste trabalho. As camadas são: Pedologia; Arruamento; Declividade das ruas; Nível de lençol freático; Uso e Ocupação do solo; Distância dos córregos e; Área de drenagem linear. Todas as camadas foram desenvolvidas em ambiente SIG. Para facilitar a reprodução dos métodos utilizados neste trabalho, o processo de álgebra de mapas utilizado foi desenvolvido de maneira simples e direta e, portanto, não se fez uso de camadas oriundas de algum processamento complexo de dados geoespaciais ou originadas de dados de difícil obtenção. É importante destacar que a metodologia utilizada visa uma primeira avaliação das áreas da cidade quanto à sua adequabilidade para recebimento de técnicas compensatórias. Por isso, são analisados apenas características físicas das áreas, não sendo levado em conta fatores ambientais, sanitários, de integração, entre outros.

\subsubsection{Pedologia}

O material que originou esta camada foi obtido junto ao Plano Diretor de Drenagem Urbana de São Carlos e foi georreferenciado a partir da própria grade presente no mapa (Figura 15). O mapa é resultado da vetorialização da imagem raster do plano diretor. Dentre os solos existentes na bacia hidrográfica, apenas o litossolo eutrófico - identificado em três pequenas porções na bacia muito próximos ao córrego 
principal - é considerado de baixa permeabilidade e, segundo Sartori (2005), é classificado como tipo D. Os outros três tipos de solo são classificados como tipo B para utilização no método do NRCS.

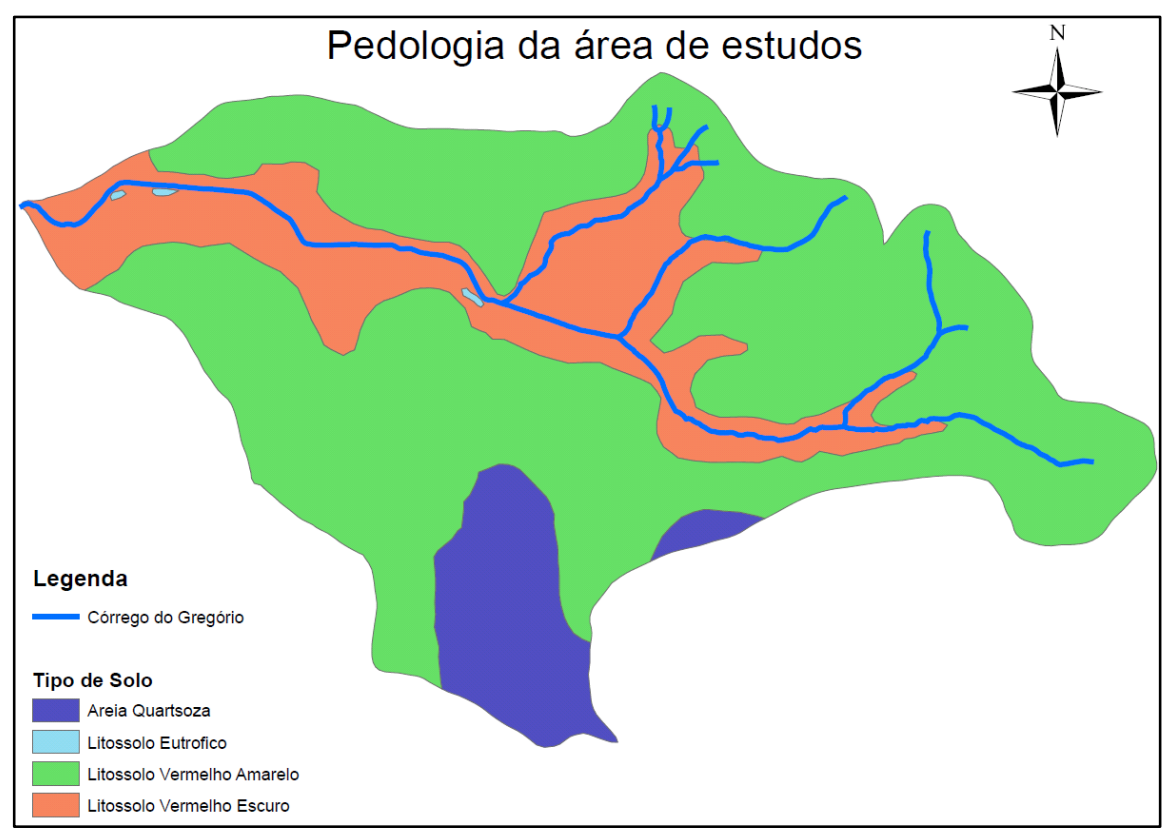

Figura 15 - Mapa de pedologia da área de estudos utilizado no processo de álgebra de mapas

\subsubsection{Arruamento}

O layer das ruas foi criado manualmente a partir da imagem de satélite e consiste em uma camada vetorial com linhas representando as ruas (Figura 16), divididas segundo a distribuição das quadras urbanas, ou seja, cada rua foi dividida em segmentos que percorrem não mais que a distância de uma quadra. Este processo foi importante pois, além de representar a disposição espacial das ruas, o que permite delimitar os locais onde podem ser implantadas técnicas compensatórias lineares, ainda permite que se calcule a declividade de cada trecho de rua, informação essencial à produção dos mapas de adequabilidade. 


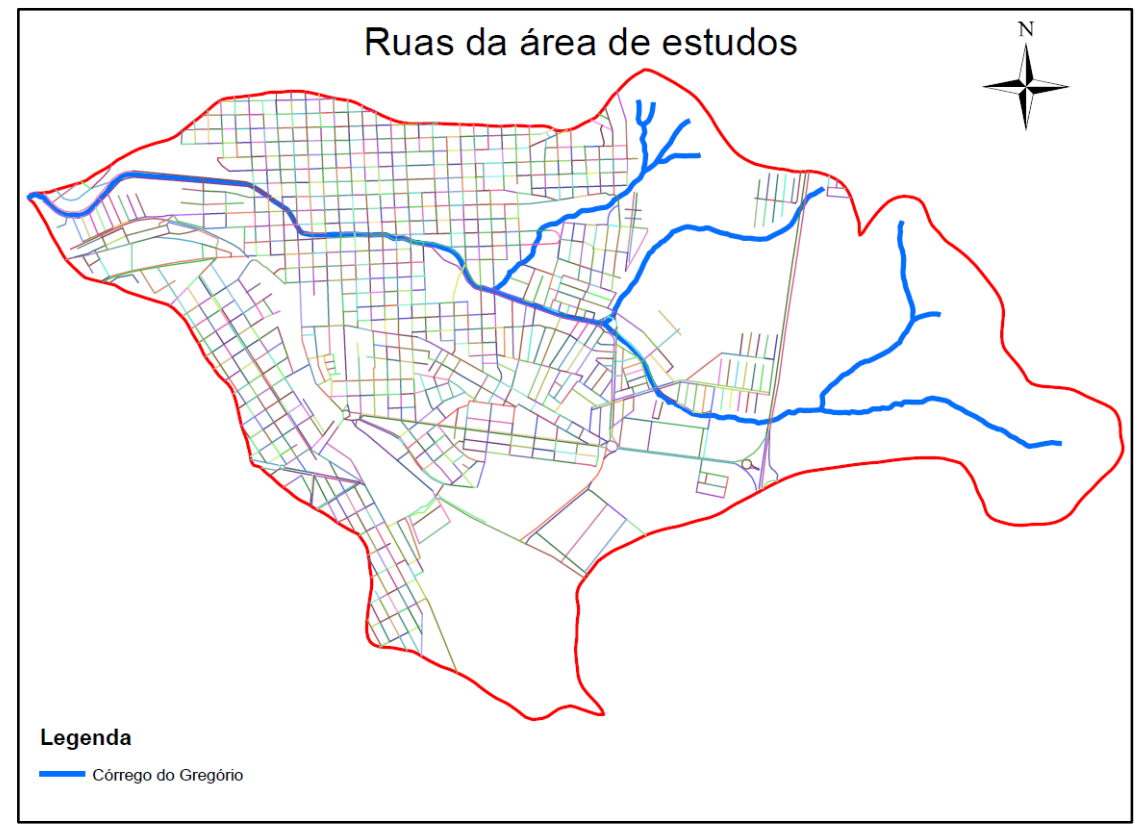

Figura 16 - Mapa de arruamento da área de estudos utilizado no processo de álgebra de mapas

\subsubsection{Declividade das ruas}

Os valores de declividade das ruas foram calculados a partir de duas camadas, uma camada vetorial das ruas separadas trecho a trecho e um Modelo Digital de Elevação (MDE). Em posse destas camadas foi executada uma rotina em ambiente SIG para a obtenção dos valores de declividade das ruas, trecho a trecho. Na Figura 17 apresenta-se o resultado da declividade das ruas separando-as em duas classes, declividade superior e inferior a $5 \%$. 


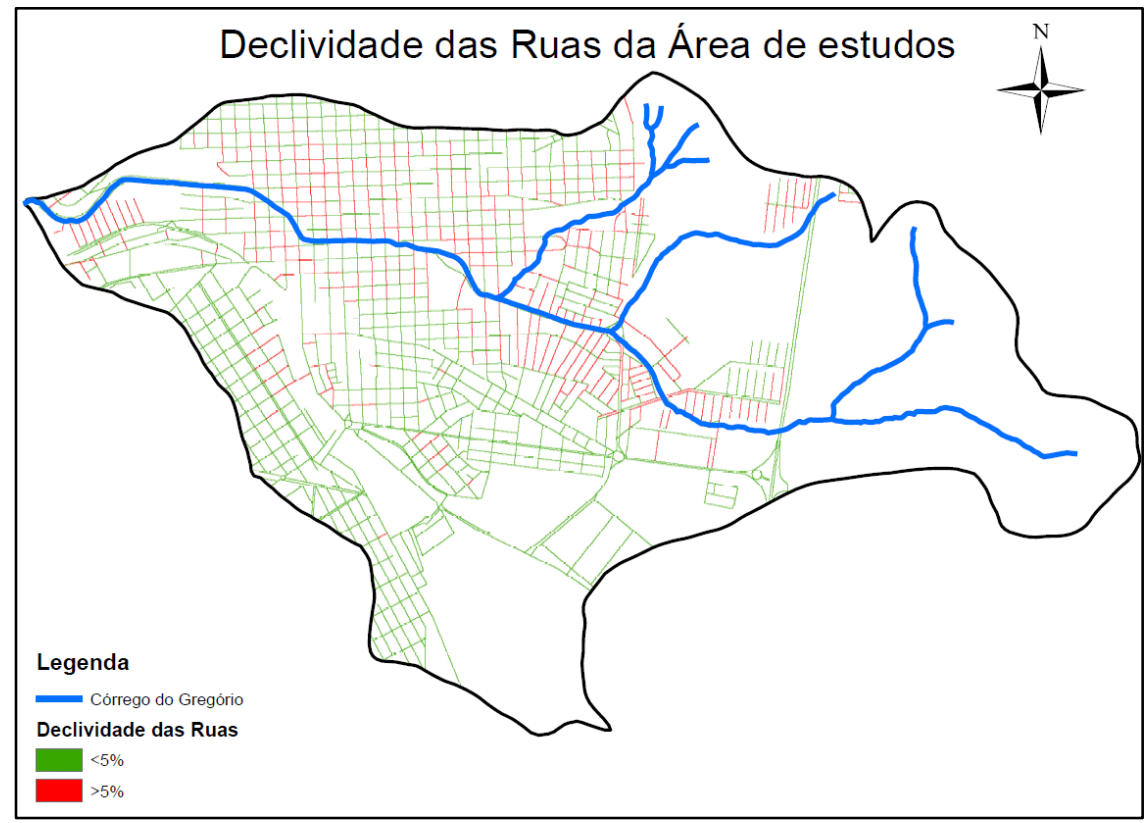

Figura 17 - Mapa de declividade da área de estudos classificados em declividades superiores e inferiores a $5 \%$

\subsubsection{Nível do lençol freático}

Para o desenvolvimento desta camada foram utilizados diversos pontos com profundidade de lençol freático obtidos por Bartolomeu (2012). A partir destes dados pode-se gerar uma camada referente à superfície do lençol freático (Figura 18) utilizando-se uma rotina de interpolação de superfícies em ambiente SIG.

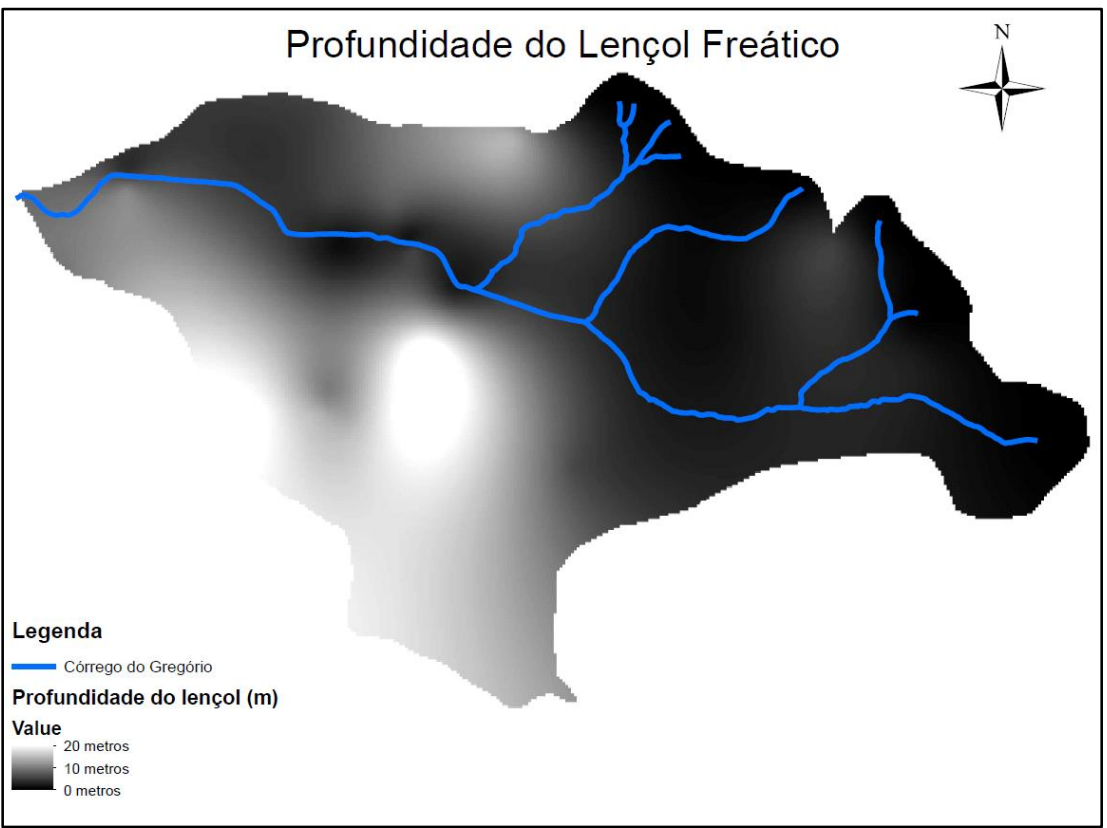

Figura 18 - Mapa de profundidade de lençol freático da área de estudos 


\subsubsection{Uso e ocupação do solo}

Foi utilizado no trabalho um mapa de uso e ocupação do solo (Figura 19) produzido por Message (2014), que utilizou um processo de fotointerpretação e classificação manual de regiões da cidade e dividiu-as em 7 classes, conforme apresentado na figura a seguir.

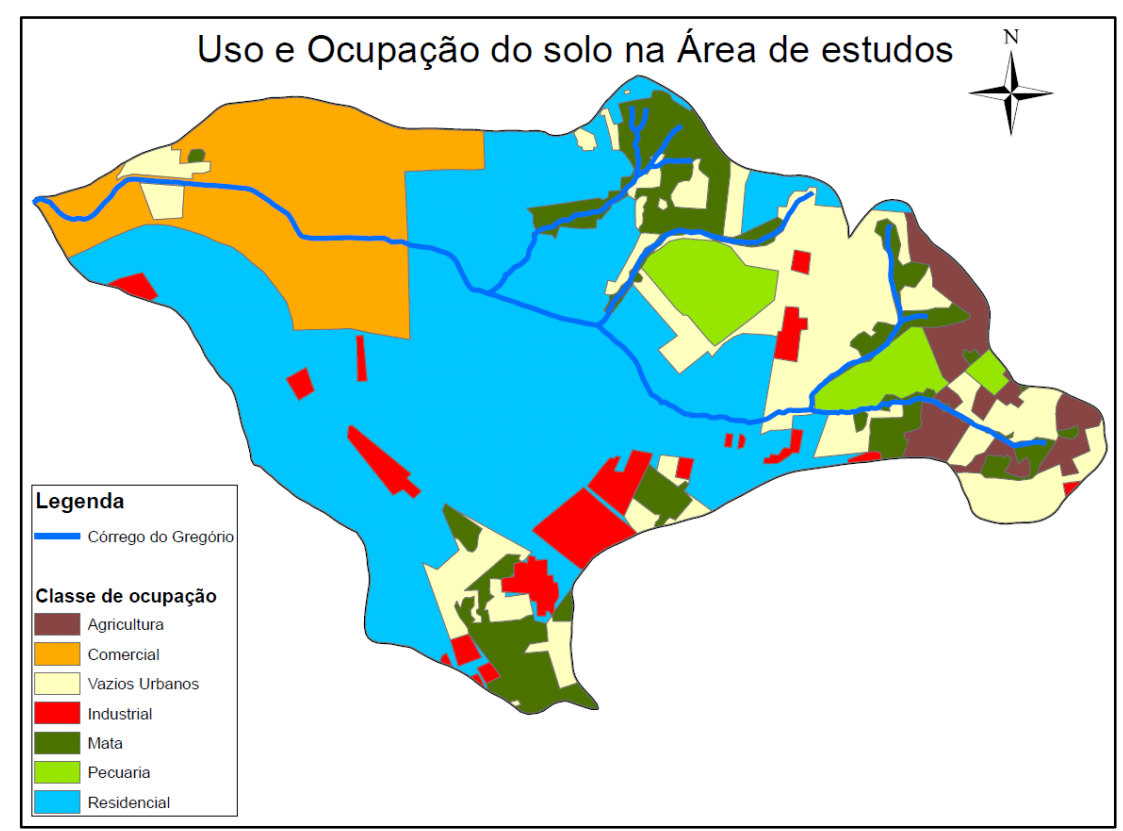

Figura 19 - Mapa de uso e ocupação do solo da área de estudos utilizado no processo de álgebra de mapas

\subsubsection{Distância dos córregos}

A camada de distância dos córregos foi criada a partir de uma rotina Buffer, que delimita uma área de influência com 100 metros de distância do eixo dos córregos (Figura 20). A camada foi criada pois, segundo recomendações internacionais, diversos dispositivos compensatórios não são permitidos nas proximidades dos rios. 


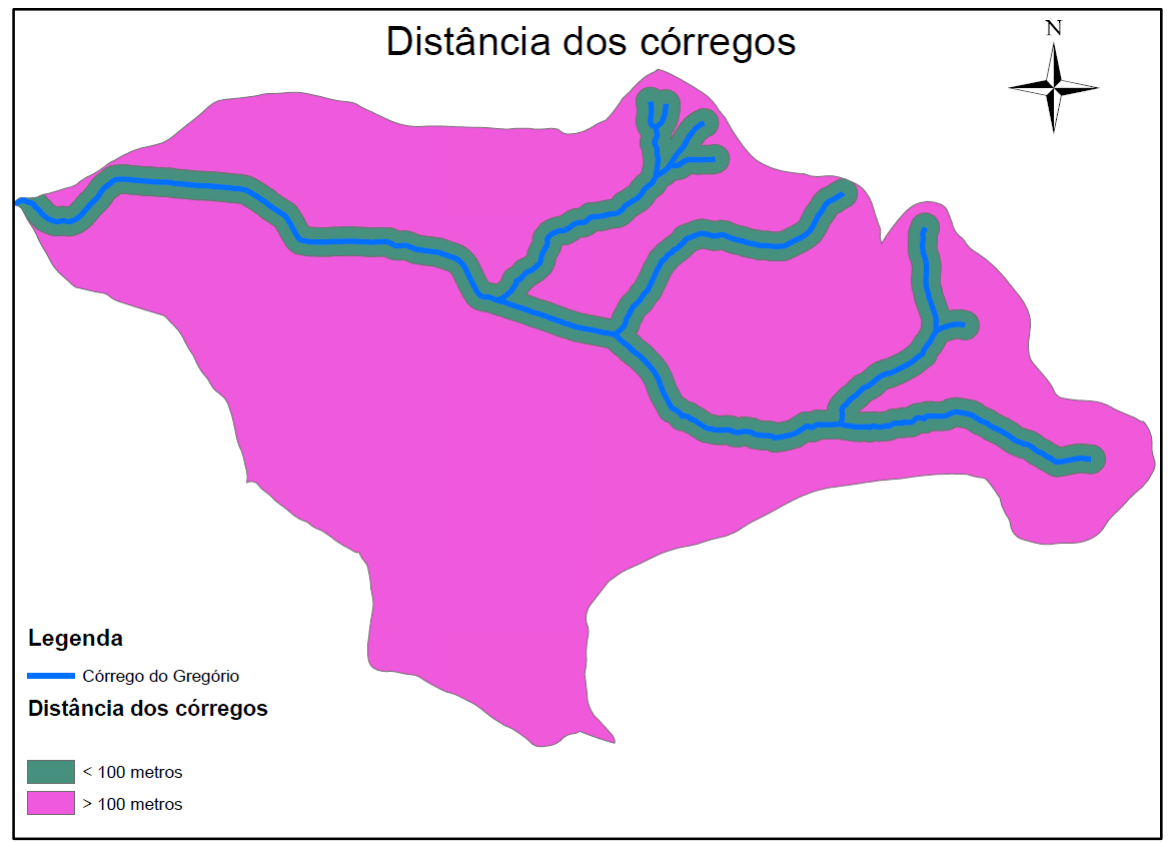

Figura 20 - Mapa de distância de córregos delimitando a faixa mínima de 100 metros de distância de corpos de água

\subsection{7 Área de drenagem linear}

A camada de área de drenagem linear foi criada para a geração dos mapas de adequabilidade das técnicas compensatórias lineares, já que estes dispositivos têm limites máximos de área de contribuição de drenagem para que funcionem corretamente. Apesar de existirem ferramentas SIG que permitem a identificação de linhas de fluxo preferenciais em bacias hidrográficas, a criação desta camada exigiu uma adaptação exclusiva desta metodologia para a finalidade de identificação de linhas de fluxo lineares em ambiente urbano, uma vez que as linhas de fluxo em área urbana se ordenam não só pelo relevo da bacia, mas também pela disposição espacial das quadras, que possuem sarjetas para a condução da água de escoamento. Além disso, em cidades onde existe microdrenagem com bocas de lobo, estas devem ser consideradas no processo, uma vez que causam uma interrupção das linhas de fluxo pela coleta da água de escoamento superficial. Na cidade de São Carlos, pela escassez de galerias de microdrenagem e principalmente pela falta de cadastro e informações quanto à sua condição de funcionamento, esta não foi considerada no processo.

$\mathrm{Na}$ criação desta camada foi utilizado um conjunto de ferramentas, em ambiente SIG, comumente utilizadas para identificação das redes de drenagem 
naturais de um terreno. A rotina é composta por 3 etapas básicas que são: determinação da direção de fluxo de cada pixel da imagem, criação das linhas de fluxo e, por fim, criação de uma imagem de fluxo acumulado, onde se atribui a cada pixel da imagem o número de pixels que este drena, conforme a Figura 21.
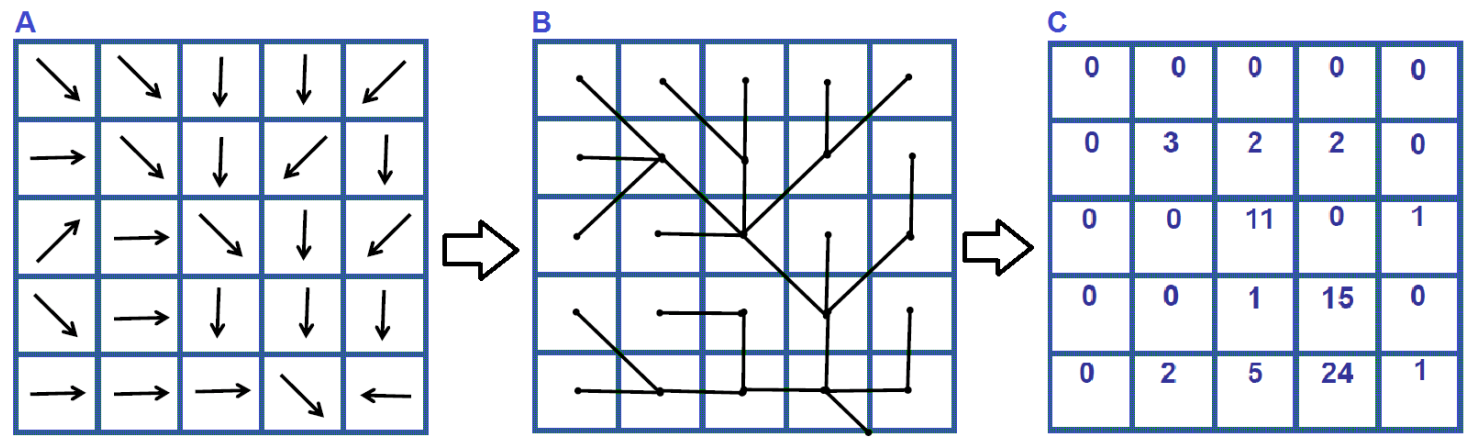

Figura 21 - Rede de drenagem em SIG em 3 etapas: (A) determinação da direção de fluxo (B) linhas de fluxo e (C) fluxo acumulado

Para o processo de fluxo acumulado em ambiente urbano foi necessária a adaptação da metodologia para se identificar a drenagem superficial. Inicialmente, criou-se um novo MDE a partir do recorte do MDE original, no qual foram mantidos os valores de altitude reais das ruas e avenidas mas alterou-se os valores de altitude dos pixels das quadras para valores superiores aos das ruas, mas iguais entre si. Desta maneira, ao se realizar a etapa de cálculo da direção de fluxo da água, o SIG reproduz a maneira usual de interpretação de fluxo utilizada em drenagem urbana, na qual divide-se a quadra em 4 parcelas, cada parte sendo drenada pela aresta com a qual faz fronteira, conforme apresentado na Figura 22.

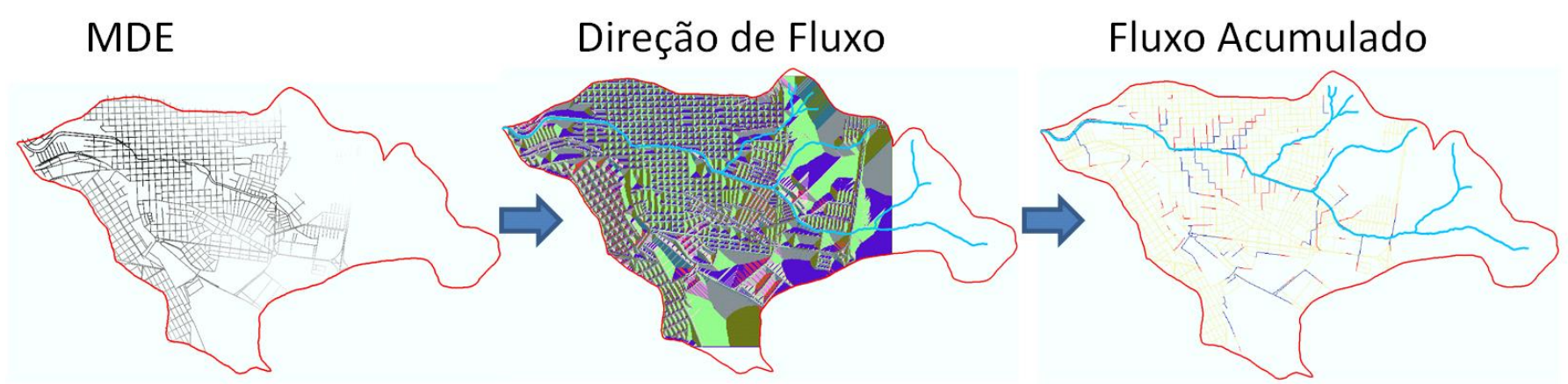

Figura 22 - Processo de obtenção de linhas de fluxo superficial em área urbana

Com o mapa de direção de fluxo, é possível estimar o sentido de fluxo da água na superfície do terreno e calcular a área de drenagem de cada pixel do modelo 
utilizando uma unidade de "número de pixels", permitindo assim que se calcule qual a área real drenada por cada trecho de rua.

Para o cálculo de área de drenagem de cada trecho de rua, utilizando a abordagem clássica em drenagem urbana, considera-se que cada trecho de rua recebe a contribuição de metade de uma quadra (um quarto de cada lado da rua) e mais a área da própria rua. Pela resolução do MDE utilizado, cada pixel representa 8 por 8 metros em uma escala real, o que faz com que cada trecho de rua (100 metros de comprimento, em média) tenha 12,5 pixels de comprimento por 1 pixel de largura (por terem 10 metros de largura, em média, as ruas são melhor representadas por uma fileira de pixels do que duas fileiras paralelas) e cada hectare seja representado por 156,25 pixels $\left(10.000 \mathrm{~m}^{2}\right.$ dividido por $\left.64 \mathrm{~m}^{2}\right)$. Assim, pode-se considerar que cada pixel situado em uma rua possui 0,064 hectares de área de drenagem. A seguir são apresentados a Figura 23 e a Figura 24 com os detalhes da direção de fluxo e o resultado final do mapa de área de drenagem das ruas.

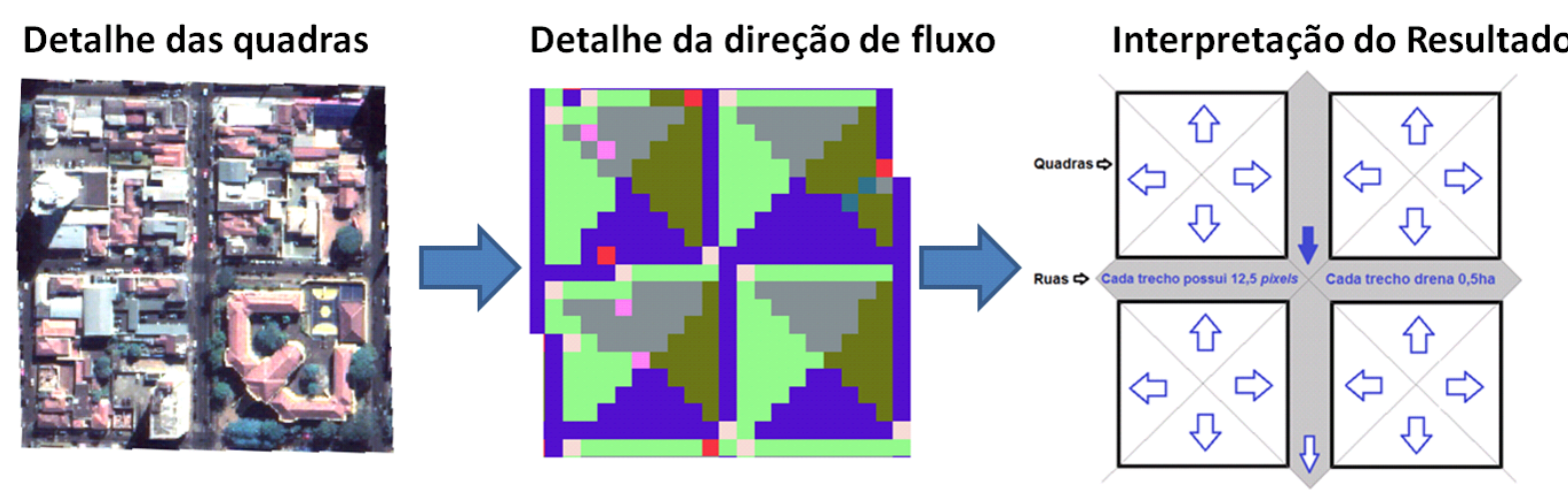

Figura 23 - Criação de linhas de fluxo de drenagem em área urbana 


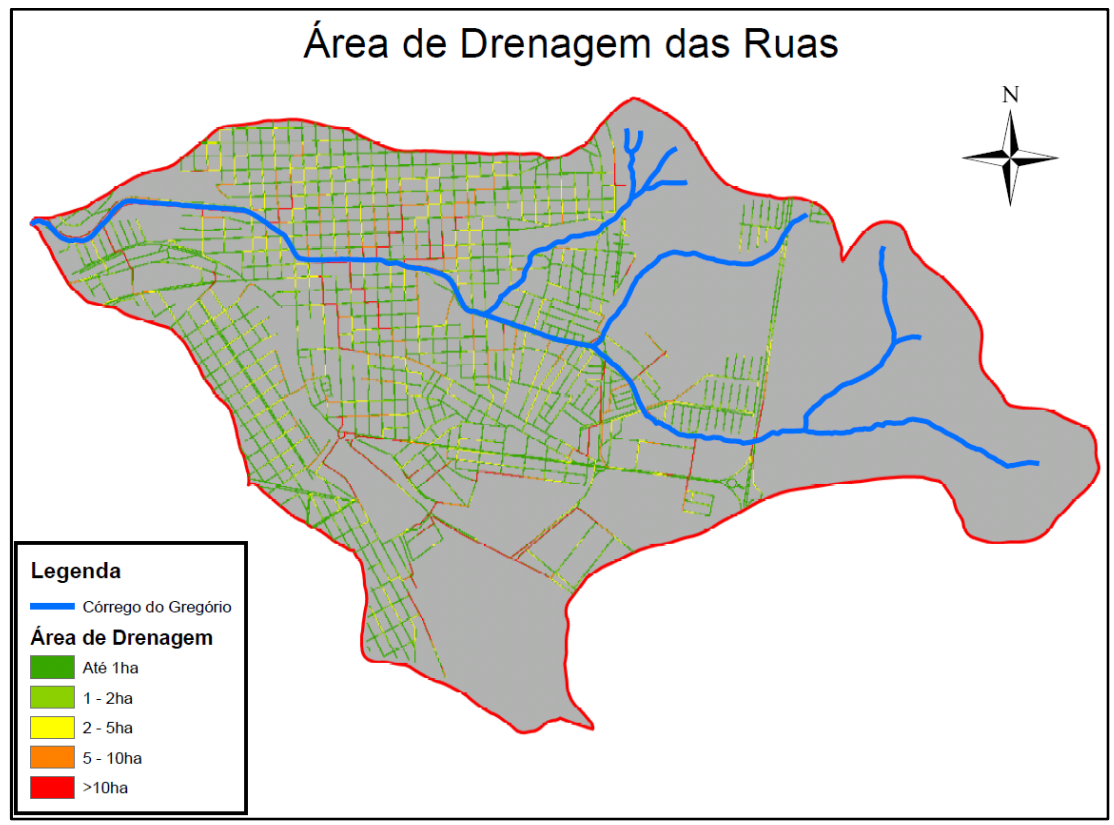

Figura 24 - Mapa de área de drenagem superficial de cada rua da bacia hidrográfica

\section{7 ÁLGEBRA DE MAPAS}

O processo de álgebra de mapas envolve o cruzamento das camadas, na forma de matrizes, para criação de um mapa final com as informações desejadas. Assim, deve-se decidir quais camadas farão parte do processo e, o mais importante, quais informações das camadas conduzirão a álgebra de mapas até o resultado esperado. Assim, um mesmo conjunto de camadas pode gerar diversos mapas diferentes para diferentes tipos de dispositivos, como exemplificado na Figura 25.
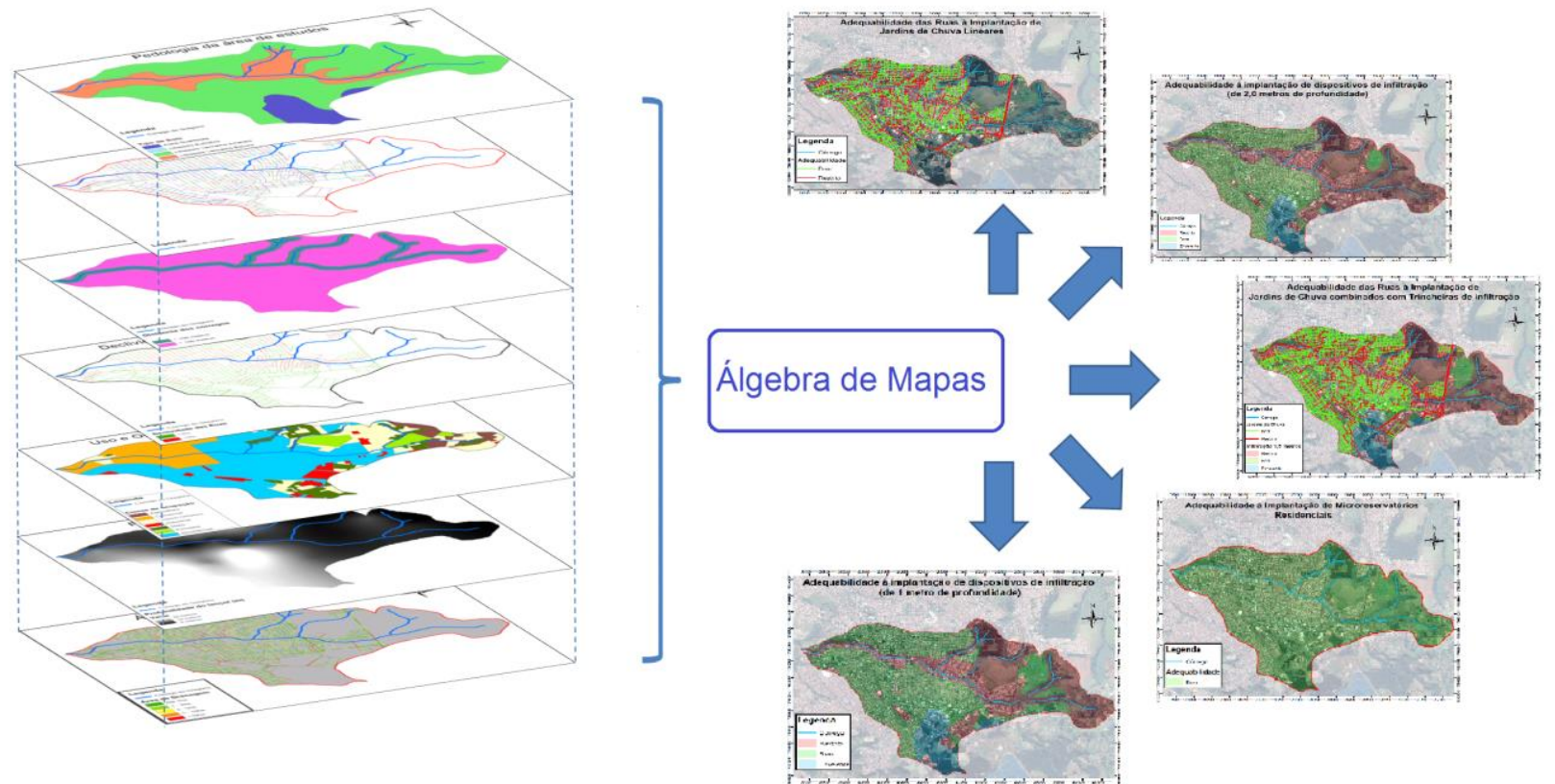

Figura 25 - Álgebra de mapas 
Os dispositivos compensatórios aos quais serão produzidos mapas de adequabilidade e as camadas utilizadas no processo de álgebra são apresentados na Tabela 5.

Tabela 5 - Mapas utilizados no processo de álgebra de mapas para cada técnica compensatória

\begin{tabular}{|c|c|c|c|c|c|c|c|c|}
\hline & 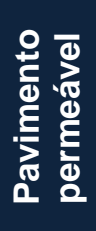 & 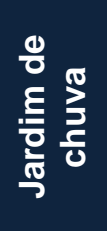 & 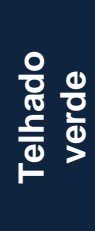 & 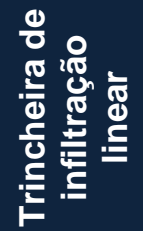 & 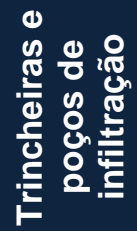 & 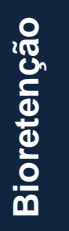 & $\frac{\text { एా }}{\frac{5}{0}}$ & $\frac{\pi}{\frac{\pi}{0}}$ \\
\hline Pedologia & $X$ & $X$ & & $X$ & $X$ & $x$ & & \\
\hline Ruas & $X$ & $x$ & & $X$ & & $x$ & & $x$ \\
\hline $\begin{array}{l}\text { Declividade } \\
\text { das ruas }\end{array}$ & $X$ & $X$ & & $X$ & & $X$ & & $X$ \\
\hline $\begin{array}{l}\text { Nível do lençol } \\
\text { freático }\end{array}$ & $X$ & $X$ & & $X$ & $x$ & $X$ & & \\
\hline $\begin{array}{c}\text { Uso e } \\
\text { ocupação do }\end{array}$ & & & & & $X$ & & & \\
\hline $\begin{array}{l}\text { Distância do } \\
\text { córrego }\end{array}$ & $X$ & $X$ & & $X$ & 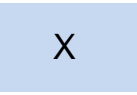 & $\mathrm{X}$ & & $x$ \\
\hline $\begin{array}{c}\text { Área de } \\
\text { contribuição }\end{array}$ & & $X$ & & $X$ & & $X$ & & \\
\hline
\end{tabular}

\subsubsection{Pavimento permeável}

Para a área de estudo, o mapa de adequabilidade quanto à implantação de pavimentos permeáveis utilizou cinco camadas no processo de álgebra de mapas: pedologia, ruas, declividade das ruas, nível de lençol freático e distância de córregos. Para pedologia, permitiu-se a implantação em solos A e B, somente. Para declividade de ruas, o limite aceitável foi de $5 \%$ e para nível de lençol freático restringiu-se a aplicação à profundidade superior a 1 metro. Na distância dos córregos, respeitou-se o limite de mais de 100 metros entre pavimento e canal.

Além disso, o mapa foi conferido manualmente após o processo de álgebra de mapas para que se atendesse a uma recomendação técnica de não implantação de pavimento permeável em ruas com grande fluxo de carros. Assim, a partir do conhecimento da área de estudos pelo pesquisador, algumas ruas deixaram de receber o dispositivo por apresentarem grande fluxo de veículos. 
Para a realização de processos de álgebra de mapas, inicialmente são atribuídos valores ou faixas de valores aos pixels que compõem os mapas iniciais do processo. O processo de álgebra de mapas dos pavimentos permeáveis foi relativamente simples, uma vez que nos cinco mapas utilizados haviam somente duas classes de pixels, os aptos e os não aptos a receberem os dispositivos pavimentos permeáveis. Para maior compreensão do processo, inicia-se pelo exemplo do mapa de declividade das ruas que é reclassificado para que ruas com declividade superior a $5 \%$ sejam eliminadas (seus pixels recebem valor 0 na imagem) e ruas com declividades inferiores a 5\% seriam mantidas (pixels valor 1 na imagem). Assim, a imagem resultante da reclassificação possui apenas duas classes de valores, 0 e 1 , ou não aptos e aptos.

O mesmo processo ocorre para profundidade de lençol freático, no qual regiões com profundidades maiores que 1 metro recebem valor 1 e regiões de profundidades menores recebem valor 0 . Assim, produz-se um mapa binário, com um valor real e outro nulo. O mesmo processo ocorre para separação da área entre ruas e não ruas, para se restringir áreas com distâncias menores de 100 metros de córregos (não permitido) e distâncias maiores (permitido) e se limitar a aplicação a determinados tipos de solo.

A operação matemática utilizada entre os mapas foi a multiplicação. No resultado, qualquer área com resultado igual a 1 representa uma rua apta a receber pavimentos permeáveis, enquanto áreas de valor 0 ficam inaptas. $O$ processo é ilustrado na Figura 26.

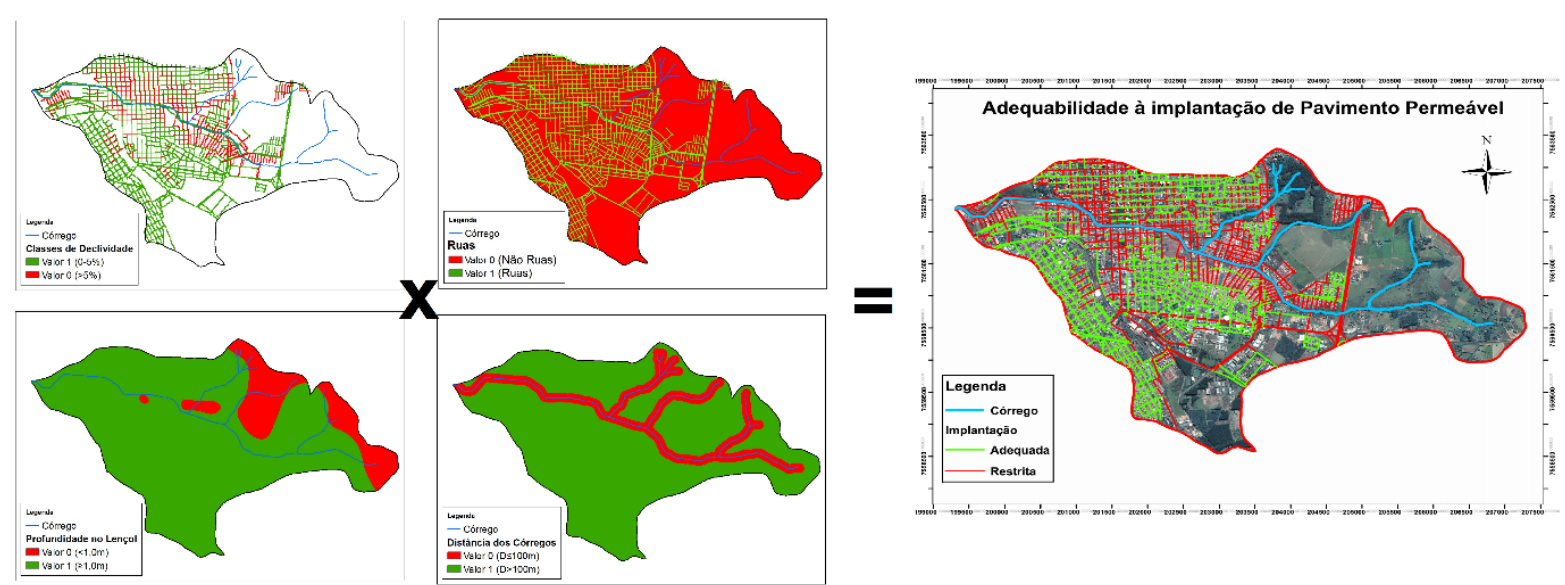

Figura 26 - llustração do processo de álgebra de mapas para a produção do mapa de adequabilidade à implantação de pavimentos permeáveis 


\subsubsection{Jardins de chuva}

$\mathrm{Na}$ geração do mapa de adequabilidade à implantação de jardins de chuva foram utilizadas seis camadas de mapas. Como os jardins de chuva propostos são lineares, foram utilizadas as camadas de arruamento e declividade das ruas, $(10 \%$ de declividade), conforme recomendam o "LID Technical Guidance Manual for Puget Sound" e o "Eastern Washington LID Guidance". Quanto à pedologia, foram permitidos solos do tipo $\mathrm{A}$ e $\mathrm{B}$. Além disso, limitou-se o nível de lençol freático àqueles superiores a 1 metro, distância das ruas superior a 100 metros e área de contribuição iguais ou menores que 2 hectares, conforme orientação do Manual de Drenagem de São Paulo.

\subsubsection{Telhados verdes}

Dentre todos os dispositivos, os telhados verdes - junto com os microreservatórios individuais - são os dispositivos com menor número de restrições, sendo na maioria das vezes sem qualquer tipo de restrição nos manuais técnicos referentes à condição física da área urbana. Entretanto, faz-se a ressalve que os telhados a serem adaptados devem apresentar as condições estruturais adequadas para suportar o peso dos dispositivos. A falta de restrições quanto à área urbana ocorre pois telhados verdes e microreservatórios são dispositivos exclusivamente armazenadores e não precisam de disponibilidade de espaço ou solo adequados (no caso do telhado verde, o solo utilizado não necessariamente é o solo nativo) para sua implantação. Assim, no mapa de adequabilidade de ambos não foram utilizadas camadas para álgebra de mapas, uma vez que toda a bacia está apta a receber os dispositivos.

\subsubsection{Trincheiras e poços de infiltração}

Trincheiras e poços de infiltração são dispositivos de infiltração que utilizam o mesmo princípio de controle de escoamento (armazenamento temporário e infiltração do escoamento) mas possuem construtivos diferentes, podendo diferir no formato, profundidade, preenchimento interno, contenção lateral, disposição espacial do dispositivo, entre outras características. Assim, optou-se por gerar apenas dois tipos 
de mapas de adequabilidade de implantação: trincheiras lineares, no qual trincheiras de diferentes profundidades poderiam ser locadas e; dispositivos de infiltração, no qual trincheiras e poços poderiam ser locados, e diferentes variações do mapa orientariam quanto à profundidade do dispositivo permitido.

No mapa de adequabilidade à implantação de trincheiras lineares, foram utilizadas 6 camadas de mapas. Quanto à pedologia, foi permitida a instalação apenas nos solos mais permeáveis, os do tipo A e B. Quanto à declividade, apesar do Manual de Drenagem de São Paulo permitir a instalação em declividades superiores a 5\%, este foi o valor limite utilizado durante o processo de álgebra de mapas. Esta decisão foi baseada no fato de que são comuns trincheiras de infiltração lineares dispostas ao longo de todo o trecho de uma rua (em média 100 metros) e, para trincheiras longas, quanto maior a inclinação, menor o volume aproveitável para armazenamento no dispositivo, uma vez que a linha da superfície da zona saturada não segue a linha de superfície da trincheira e sim o plano horizontal, conforme exemplificado na Figura 27. Assim, se permitidas trincheiras com mais de $5 \%$ de inclinação, estas não seriam tão eficientes no armazenamento e combate ao escoamento superficial.

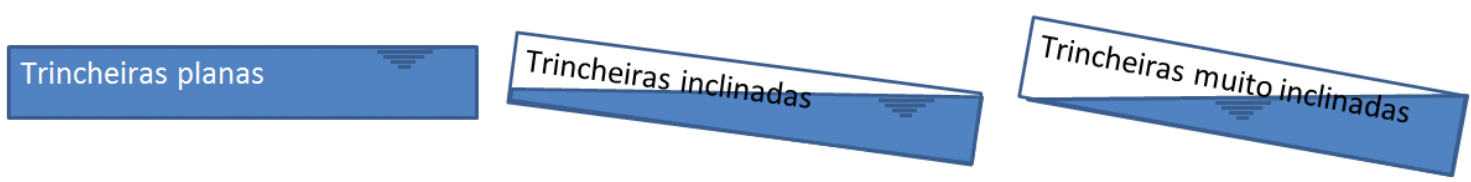

Figura 27 - Armazenamento de água pelas trincheiras segundo sua inclinação

No processo de álgebra de mapas para trincheiras lineares foram utilizadas ainda as camadas de nível de lençol freático, com limite de pelo menos 1 metro de profundidade e distância de córregos com valor mínimo de 100 metros.

Além deste, outro mapa foi produzido, o de adequabilidade da área à implantação de dispositivos de infiltração, onde estão incluídos trincheiras e poços instalados pontualmente. Neste, conforme a Tabela 5, foram utilizadas as camadas de pedologia, com permissão de instalação apenas em solos do tipo A e B, nível de lençol freático igual ou superior a 1 metro (depende do mapa produzido), distância de córregos superior a 100 metros e ainda foi utilizada uma camada de classificação de uso e ocupação de solo, restringindo-se assim a instalação de dispositivos de infiltração em zonas classificadas como industriais. Neste mapa, a área de estudos foi classificada em 3 porções, uma restrita à implantação, uma adequada e outra 
classificada como excelente devido ao tipo do solo ser areia quartzosa que, apesar de ser do tipo B, é individualmente o mais permeável encontrado na bacia. Este mapa foi produzido destinado à avaliação quanto à implantação de trincheiras e poços de infiltração na fonte como, por exemplo, em praças, parques, lotes ou estacionamentos.

\subsubsection{Microreservatórios individuais}

Nos manuais consultados, foram encontradas pouca ou nenhuma restrição ou mesmo recomendações técnicas para a implantação de microreservatórios individuais de qualquer tipo. A única restrição foi de que possuam áreas de contribuição menores que 2 hectares. Devido à raridade de telhados ou outras áreas com mais de 2 hectares que contribuam com cisternas, repete-se o caso dos telhados verdes, onde não foram utilizadas camadas para o processo de álgebra de mapas, estando toda a bacia apta à implantação destes dispositivos.

\subsubsection{Valas vegetadas}

As valas vegetadas são dispositivos lineares instalados ao longo de ruas e tem como funções o aumento do tempo de trânsito do escoamento, a promoção de infiltração e a manutenção da qualidade da água escoada. Apesar de consolidados na drenagem sustentável, estes dispositivos se mostram mais apropriados para regiões ainda em desenvolvimento e que dispõem de amplo espaço para implantação. Em áreas densamente urbanizadas, a falta de espaço praticamente inviabiliza a implantação destes dispositivos. Além disso, mesmo em casos em que se disponha de espaço, é mais razoável a ocupação do espaço com dispositivos que, além de controlarem escoamento com mais eficiência, permitam a utilização da área para mais de uma finalidade, como trincheiras de infiltração que permitem carros estacionados em sua superfície ou mesmo pavimentos permeáveis. Somado a isso tudo, reitera-se que este trabalho visa principalmente o controle quantitativo do escoamento superficial, devendo-se assim priorizar dispositivos mais eficientes no controle à quantidade de escoamento superficial na bacia. Assim, optou-se pela não criação de mapas de adequabilidade à implantação de valas vegetadas na área de estudos e, 
consequentemente, opta-se pela não criação de cenários de utilização das valas vegetadas na área de estudos.

\subsection{SIMULAÇÃO HIDROLÓGICA}

A etapa de simulação hidrológica do trabalho teve como finalidade averiguar, hidrologicamente, quais os efeitos da implantação extensiva das técnicas compensatórias dispostas isoladamente (um cenário para cada técnica compensatória) e também dispostas em conjunto, ou seja, com diferentes tipos de técnicas compensatórias funcionando ao mesmo tempo na bacia de modo seus efeitos fossem combinados no controle de escoamento. Uma vez que o desempenho de uma técnica compensatória depende dos volumes afluentes e que diferentes técnicas podem trabalhar linearmente ou paralelamente, o resultado desta simulação conjunta é um questionamento frequente dos profissionais da área e planejadores urbanos.

Para a etapa de simulação hidrológica, optou-se por utilizar apenas dados sintéticos de precipitação e nenhum dado real de vazão para calibração. Isto ocorreu pois a bacia do Gregório, apesar de bastante estudada e monitorada, é de difícil monitoramento fluvial, com ondas de cheia bastante rápidas, muitas vezes com velocidades de escoamento superiores a $7 \mathrm{~m} / \mathrm{s}$, dificultando a medição hidrométrica por métodos tradicionais, o que poderia comprometer a qualidade de dados obtida. Além disso, pelo caráter comparativo que foi adotado na análise de resultados hidrológicos, a ausência de calibração com dados reais de chuva-vazão não prejudica, de modo geral, os resultados.

$\mathrm{Na}$ simulação, inicialmente, criou-se um modelo da bacia hidrográfica no SWMM5.0 no qual a bacia foi dividida em 13 sub-bacias e toda a rede de macrodrenagem foi inserida no modelo, tal qual se encontra no presente. Em seguida, foram criados cenários hipotéticos de situação de rede de drenagem e ocupação da bacia, compostos por situações onde as técnicas compensatórias fossem aplicadas extensivamente uma a uma, permitindo que se averiguasse seus efeitos no hidrograma da bacia. Por fim, as técnicas compensatórias mais eficazes na redução da vazão de pico foram reunidas em um só cenário e obteve-se um modelo final para se avaliar o resultado das técnicas compensatórias trabalhando em conjunto. 
Na simulação hidrológica, foram utilizadas precipitações sintéticas geradas a partir de uma equação intensidade-duração-frequência (IDF) com durações de $60 \mathrm{e}$ 120 minutos e tempos de retorno de 2, 5, 10, 50 e 100. A equação utilizada foi a de Barbassa (1991) apresentada a seguir:

$$
i=\frac{1519 . \operatorname{Tr}^{0,236}}{(t+16)^{0,935}}
$$

Onde: $\operatorname{Tr}=$ tempo de retorno (anos)

$\mathrm{t}=$ duração da chuva (minutos)

$\mathrm{i}$ = intensidade média da precipitação $(\mathrm{mm} / \mathrm{h})$

Para dimensionamento da tormenta de projeto, inicialmente calculou-se o tempo de concentração da bacia hidrográfica. O método adotado foi o de Kirpisch pois, segundo Galbetti (2015), é o que melhor se adapta às características das bacias urbanas da cidade de São Carlos. Assim, temos que:

$$
t c=57\left(\frac{L^{2}}{I}\right)^{0,385}
$$

Onde: $\mathrm{tc}=$ tempo de concentração $(\mathrm{min})$

$\mathrm{L}=$ comprimento de talvegue $(\mathrm{km}) \mathrm{e}$;

$\mathrm{I}=$ declividade equivalente do talvegue $(\mathrm{m} / \mathrm{km})$

Sendo o comprimento do talvegue igual a $9,05 \mathrm{~km}$ e a declividade equivalente igual a $18,23 \mathrm{~m} / \mathrm{km}$, temos que o tempo de concentração da bacia do Gregório é aproximadamente 101,6 minutos. Desta maneira, optou-se por adotar um tempo de duração para a precipitação de projeto igual à 120 minutos, já que para bacias maiores que $3 \mathrm{~km}^{2}$ recomenda-se que o tempo de duração de tormenta adotado seja significativamente maior que o tempo de concentração da bacia caso sistemas de controle de cheias prevejam a construção de reservatórios (SÃO PAULO, 2012).

A afirmativa baseia-se no fato de que, nas precipitações sintéticas que utilizam o método dos blocos alternados, as maiores intensidades (principais responsáveis pelos picos de vazão) concentram-se no meio da precipitação e, caso seja aumentado o tempo de duração da precipitação, os picos de intensidade permanecem os 
mesmos, mas o volume precipitado aumenta, o que pode afetar o desempenho de dispositivos armazenadores (SÃO PAULO, 2012). Para exemplificar, na Figura 28 foram comparados os hietogramas para tempo de retorno de 10 anos e durações de 100 e 300 minutos.

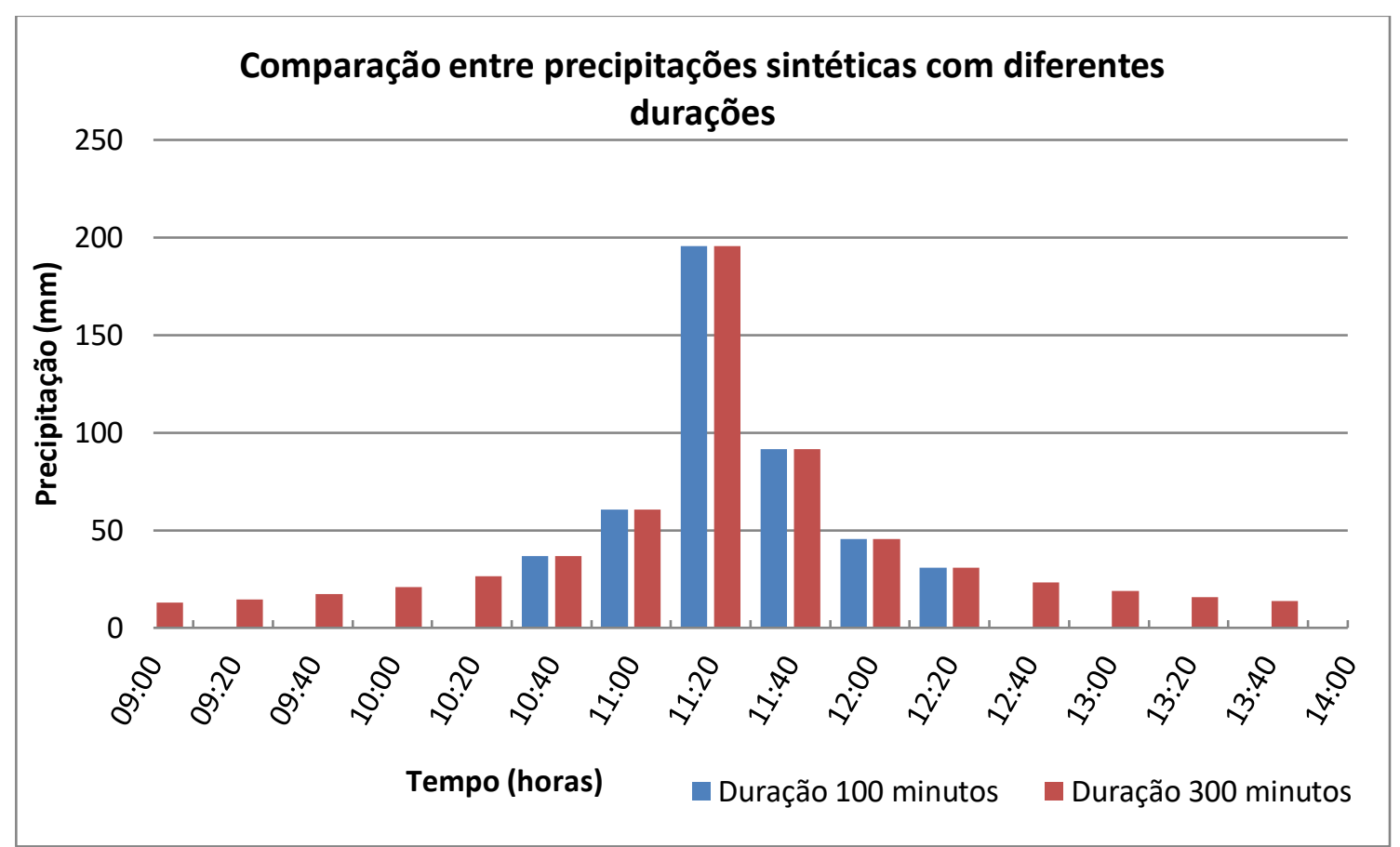

Figura 28 - Comparação entre precipitações sintéticas pelo método dos blocos alternados

Além disso, pela concepção extensiva das técnicas compensatórias que compõem o estudo, o tempo de retorno da chuva de projeto deve ser adotado baseado na recomendação utilizada para microdrenagem urbana. Como a escolha geralmente se restringe a uma faixa entre 2 a 10 anos, é aceitável que se escolha o valor que gere maiores volumes precipitados, o que levará a menores riscos pelo dimensionamento de dispositivos maiores. Assim, o tempo de retorno da tormenta de projeto para dimensionamento das técnicas compensatórias será de 10 anos. Desta forma, a tormenta de projeto para dimensionamento das técnicas compensatórias foi de 10 anos de tempo de retorno e 120 minutos de duração.

Os hidrogramas resultantes das precipitações foram gerados através do modelo SWMM, no qual foi utilizada a separação da lâmina de escoamento pelo método do NRCS (sempre para a condição de solo II, ou seja, condições médias de umidade de solo), antigo SCS, e a propagação do hidrograma foi feita através do método da onda cinemática. Na avaliação da eficiência dos dispositivos utilizados em 
cada cenário, foi feita uma simples comparação dos hidrogramas resultantes em cada cenário com os hidrogramas obtidos pelo modelo do estado atual da bacia hidrográfica do córrego do Gregório.

\subsubsection{Bacia hidrográfica do córrego do Gregório}

Como a simulação hidrológica ocorreu com diferentes configurações de bacias hidrográficas, a maioria representando cenários hipotéticos de implantação de técnicas compensatórias, a simulação da bacia em seu estado atual foi chamada de cenário real. Neste, a bacia hidrográfica do Córrego do Gregório foi dividida em 13 sub-bacias para inserção no modelo SWMM (Figura 29). Na modelagem, foi utilizado o método do CN-NRCS na separação do escoamento superficial, além de valores de percentual de área impermeabilizada, profundidade das depressões em zonas impermeáveis e permeáveis e percentual de zonas impermeáveis sem armazenamento em depressões, todos parâmetros usados pelo modelo na conversão chuva-vazão. Além destes, são necessários como dados de entrada das sub-bacias os parâmetros área da bacia, largura de escoamento, declividade da bacia e coeficiente $n$ de Manning de áreas permeáveis e impermeáveis. 


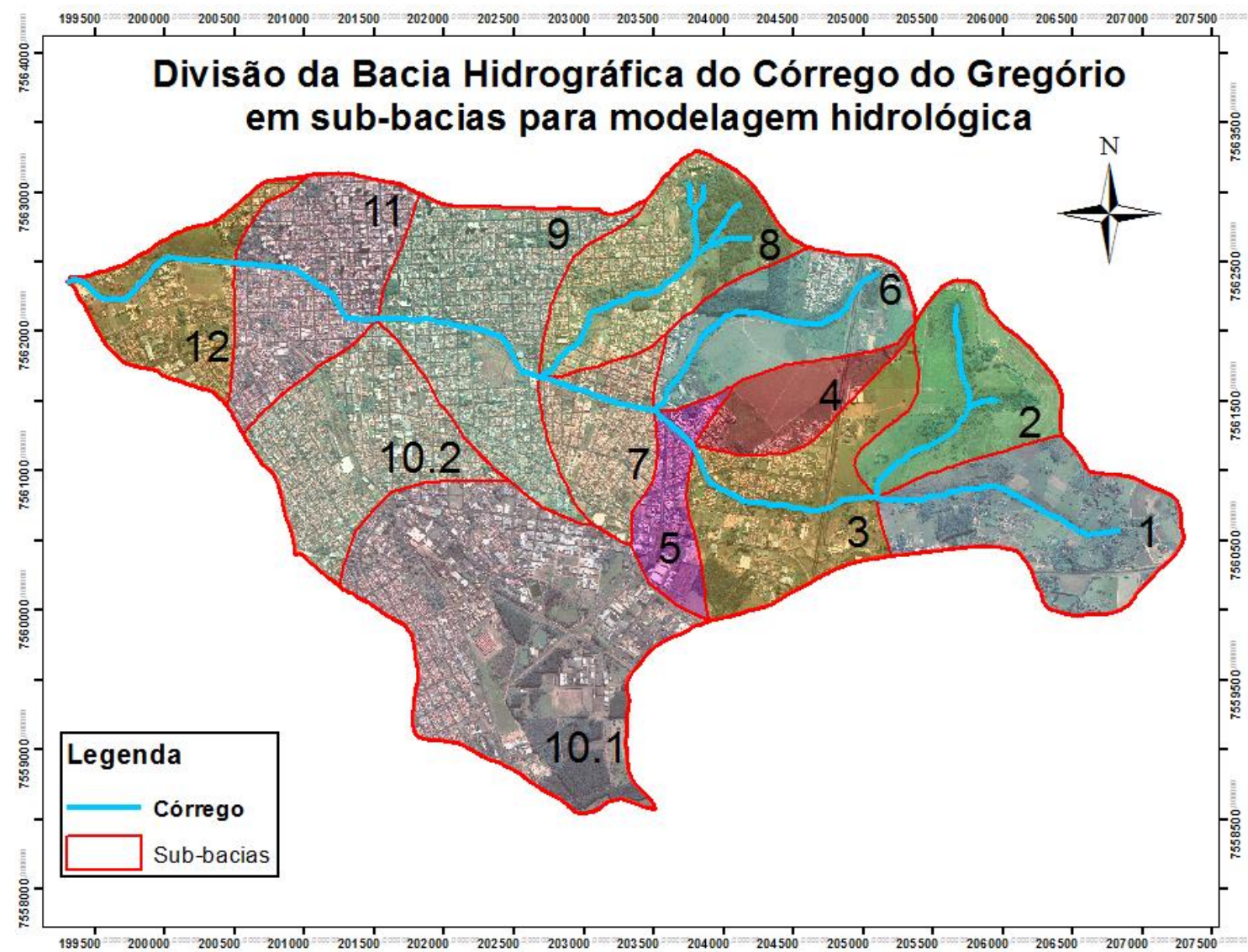

Figura 29 - Representação da bacia hidrográfica do Córrego do Gregório conforme inserida no modelo SWMM

Após o início da operação da bacia hidrográfica no modelo SWMM conforme a divisão de Martins (2012), a bacia número 10 teve de ser dividida em duas sub-bacias menores para melhores resultados na simulação hidrológica e, por dividirem a mesma linha de drenagem, sendo uma exutório da outra, permaneceram com a numeração original, porém divididas em 10.1 e 10.2. Os parâmetros que descrevem as sub-bacias encontram-se na rotina hidrológica no modelo SWMM, descrito como hidráulicohidrológico. Na etapa hidráulica, descreve-se a rede de macrodrenagem através de nós e trechos de rio, nos quais são inseridos dados de como altitude de cada nó, formato dos canais de cada trecho, profundidade máxima do canal, comprimento do trecho e rugosidade de Manning do revestimento do canal.

Os dados da rotina hidrológica foram todos obtidos por meio de sensoriamento remoto e SIG, enquanto que para os dados da rotina hidráulica houve levantamento de alguns dos parâmetros como comprimento e altitude por meio de sensoriamento remoto e SIG e os dados de seção transversal de canais foram adaptados de Barros (2005) e Shinma (2015). Os dados utilizados na descrição dos canais já consideram as 3 medidas estruturais de alteração das seções transversais de trechos do córrego 
do Gregório previstas no PDDUAS, já que estas obras já se encontram concluídas. O resumo dos dados do cenário real pode ser conferido na Tabela 6.

Tabela 6 - Dados das sub-bacias inseridos no SWMM no cenário real

\begin{tabular}{ccccccc} 
Sub-bacia & $\begin{array}{c}\text { Área } \\
\text { (ha) }\end{array}$ & $\mathbf{C N}$ & $\begin{array}{c}\text { Largura } \\
\mathbf{( m )}\end{array}$ & $\begin{array}{c}\text { Declividad } \\
\mathbf{e}(\%)\end{array}$ & $\begin{array}{c}\text { \% de área } \\
\text { impermeáve } \\
\mathbf{I}\end{array}$ & $\begin{array}{c}\text { \% de área } \\
\text { impermeável } \\
\text { sem } \\
\text { armazenamento }\end{array}$ \\
\hline $\mathbf{1}$ & 164,85 & 65,29 & 716,73 & 8,36 & $0,00 \%$ & $0,00 \%$ \\
$\mathbf{2}$ & 120,49 & 64,39 & 630,50 & 11,55 & $0,00 \%$ & $0,00 \%$ \\
\hline $\mathbf{3}$ & 156,67 & 82,91 & 645,78 & 6,94 & $25,18 \%$ & $36,04 \%$ \\
\hline $\mathbf{4}$ & 59,26 & 66,94 & 320,34 & 6,46 & $12,53 \%$ & $49,29 \%$ \\
\hline $\mathbf{5}$ & 52,83 & 82,68 & 328,54 & 4,76 & $44,51 \%$ & $44,53 \%$ \\
$\mathbf{6}$ & 126,32 & 71,22 & 557,47 & 9,09 & $12,91 \%$ & $59,02 \%$ \\
\hline $\mathbf{7}$ & 82,87 & 91,10 & 562,61 & 6,98 & $69,89 \%$ & $50,84 \%$ \\
\hline $\mathbf{8}$ & 148,63 & 74,49 & 626,61 & 9,34 & $35,41 \%$ & $68,08 \%$ \\
\hline $\mathbf{9}$ & 203,13 & 90,71 & 917,08 & 6,31 & $70,37 \%$ & $54,95 \%$ \\
\hline $\mathbf{1 0 . 1}$ & 359,75 & 79,42 & $1.240,52$ & 3,78 & $40,84 \%$ & $39,42 \%$ \\
\hline $\mathbf{1 0 . 2}$ & 156,93 & 90,37 & $1.307,76$ & 3,46 & $68,96 \%$ & $56,32 \%$ \\
\hline $\mathbf{1 1}$ & 151,90 & 89,72 & $1.301,61$ & 7,12 & $69,10 \%$ & $50,23 \%$ \\
\hline $\mathbf{1 2}$ & 105,07 & 79,48 & 497,94 & 8,49 & $39,61 \%$ & $52,83 \%$ \\
\hline
\end{tabular}

No modelo SWMM, a representação das bacias hidrográficas se dá em superfícies de escoamento, de modo que as parcelas impermeáveis e permeáveis da bacia são tratadas separadamente e, ao fim, o escoamento da bacia é resultado da soma do escoamento nas duas parcelas. Quando se trabalha com controles LID, são necessárias adaptações de alguns parâmetros, sendo os principais a largura de escoamento e percentual impermeável. A largura da bacia, no SWMM, pode ser calculada pela razão entre a área da bacia e o comprimento médio de escoamento. Com LID, a área ocupada pelos dispositivos deve ser descontada da área total da bacia e, a partir desta nova área, deve-se recalcular a largura da bacia. Além disso as áreas ocupadas por LID devem ser consideradas agora como permeáveis no cálculo de percentual de áreas impermeáveis, $\mathrm{CN}$ e percentual de áreas impermeáveis sem armazenamento em depressões. A representação das superfícies de escoamento com e sem técnicas compensatórias pode ser vista na Figura 10. Para cálculo do escoamento superficial com técnicas compensatórias na bacia, o modelo considera que uma parcela do escoamento da região impermeável é direcionada à LID e o 
restante é direcionado diretamente ao exutório e, se houver escoamento efluente da LID, este também segue para o exutório da bacia.

\subsubsection{Bacias de detenção}

Para a bacia do córrego do gregório, foram previstos cinco reservatórios de detenção in-line de águas pluviais. Assim, devido à existência deste planejamento e pela imensa dificuldade de se locar e planejar estruturas de grandes dimensões em uma região densamente urbanizada como a bacia do Gregório, optou-se por fazer a simulação hidrológica das técnicas centralizadas apenas com os reservatórios previstos no PDDUAS. A montagem do cenário com esta configuração recebeu o nome de cenário de bacias de detenção.

A inserção de bacias de detenção no modelo SWMM se dá na rede de macrodrenagem do modelo, ou seja, a representação e os efeitos de sua implantação ocorrem na etapa hidráulica do modelo. Os dispositivos são dispostos como nós de passagem na rede de macrodrenagem e são chamados de unidade de armazenamento. A representação da capacidade de armazenamento das bacias de detenção pode ser inserida por tabelas ou funções do tipo "cota $x$ área", no qual o próprio software calcula o volume dos reservatórios. Para a descarga dos dispositivos, pode-se utilizar vertedores - inseridos através de equações de vazão em função de nível de água - e descarregadores de fundo circulares ou retangulares.

Uma vez que o projeto básico das bacias de detenção encontra-se no PDDUAS (2011), a criação do cenário exigiu apenas uma adaptação do projeto ao modo de representação de dispositivos de armazenamento exigido pelo SWMM, com funções "Cota x Área" inseridos por tabelas e descarregadores representados por orifícios e vertedores.

As tabelas com valores de referência de "Cota $x$ Área $x$ Volume" para cada reservatório encontram-se nas Tabelas 7, 8, 9, 10 e 11. Todas as bacias de detenção foram projetadas para 10.000 anos de tempo de retorno, possuem vertedores de parede espessa e descarregadores de fundo circulares com 0,8 metros de diâmetro. Mais detalhes dos reservatórios podem ser obtidos em PDDUAS (2011). 
Tabela 7 - Níveis e cota x área x volume da primeira bacia de detenção do córrego Lazzarini

\begin{tabular}{|cccc|}
\hline Reservatório LA - $\mathbf{H}$ & $\mathbf{H}(\mathbf{m})$ & Área $\left(\mathbf{m}^{2}\right)$ & Volume $\left(\mathbf{m}^{\mathbf{3}}\right)$ \\
\hline Fundo & 0,00 & 0,00 & 0,00 \\
\hline N.A. volume morto & 0,00 & 0,00 & 0,00 \\
\hline N.A. soleira & 4,00 & $13.324,00$ & $25.073,00$ \\
\hline N.A. máximo max. & 4,50 & $15.325,00$ & $32.232,00$ \\
\hline Coroamento & 5,00 & $17.403,00$ & $40.418,00$ \\
\hline
\end{tabular}

Tabela 8 - Cota $x$ área $x$ volume da segunda bacia de detenção do córrego Lazzarini

\begin{tabular}{|cccc|}
\hline Reservatório LA - 2 & $\mathbf{H}(\mathbf{m})$ & Área $\left(\mathbf{m}^{2}\right)$ & Volume $\left(\mathbf{m}^{\mathbf{3}}\right)$ \\
\hline Fundo & 0,00 & 0,00 & 0,00 \\
\hline N.A. volume morto & 0,00 & 0,00 & 0,00 \\
\hline N.A. soleira & 4,58 & $9.793,00$ & $19.608,00$ \\
\hline N.A. máximo max. & 5,08 & $11.457,00$ & $24.913,00$ \\
\hline Coroamento & 5,64 & $13.547,00$ & $31.959,00$ \\
\hline
\end{tabular}

Tabela 9 - Cota x área x volume da primeira bacia de detenção do córrego do Gregório

\begin{tabular}{|cccc|}
\hline Reservatório $\mathbf{G}-\mathbf{1}$ & $\mathbf{H}(\mathbf{m})$ & Área $\left(\mathbf{m}^{2}\right)$ & Volume $\left(\mathbf{m}^{\mathbf{3}}\right)$ \\
\hline Fundo & 0,00 & 0,00 & 0,00 \\
\hline N.A. volume morto & 0,00 & 0,00 & 0,00 \\
\hline N.A. soleira & 11,13 & $71.098,00$ & $262.109,00$ \\
\hline N.A. máximo max. & 12,13 & $84.641,00$ & $339.878,00$ \\
\hline Coroamento & 13,48 & $104.819,00$ & $467.314,00$ \\
\hline
\end{tabular}

Tabela 10 - Cota x área x volume da segunda bacia de detenção do córrego do Gregório

\begin{tabular}{|cccc|}
\hline Reservatório $\mathbf{G}-\mathbf{2}$ & $\mathbf{H}(\mathbf{m})$ & Área $\left(\mathbf{m}^{2}\right)$ & Volume $\left(\mathbf{m}^{3}\right)$ \\
\hline Fundo & 0,00 & 0,00 & 0,00 \\
\hline N.A. volume morto & 0,00 & 0,00 & 0,00 \\
\hline N.A. soleira & 5,24 & $20.502,00$ & $43.042,00$ \\
\hline N.A. máximo max. & 5,49 & $21.928,00$ & $48.345,00$ \\
\hline Coroamento & 6,10 & $25.449,00$ & $62.796,00$ \\
\hline
\end{tabular}

Tabela 11 - Cota x área x volume da bacia de detenção do córrego Sorregotti

\begin{tabular}{|cccc|}
\hline Reservatório $\mathbf{S - 1}$ & $\mathbf{H}(\mathbf{m})$ & Área $\left(\mathbf{m}^{2}\right)$ & Volume $\left(\mathbf{m}^{\mathbf{3}}\right)$ \\
\hline Fundo & 0,00 & 0,00 & 0,00 \\
\hline N.A. volume morto & 0,00 & 0,00 & 0,00 \\
\hline N.A. soleira & 6,75 & $19.557,00$ & $53.790,00$ \\
\hline N.A. máximo max. & 7,25 & $21.791,00$ & $64.123,00$ \\
\hline Coroamento & 8,06 & $25.569,00$ & $83.184,00$ \\
\hline
\end{tabular}


Com exceção do reservatório G-1, que possui um enorme volume útil, os reservatórios de detenção planejados têm volumes úteis de médio porte em relação ao tamanho da bacia hidrográfica. Se comparados aos volumes comumente escoados pelos canais da bacia do Gregório, que podem chegar a $1.050 .000 \mathrm{~m}^{3}$ no exutório da bacia (para TR100 e duração de 120 minutos), nota-se que os reservatórios podem ter significativo impacto no hidrograma da bacia hidrográfica. Entretanto, vale lembrar que os reservatórios se encontram na parte menos desenvolvida da bacia e, em alguns casos, recebem vazão afluente de áreas predominantemente rurais. Portanto, através da simulação do cenário de bacias de detenção será possível avaliar se as bacias de detenção serão suficientes para a mitigação dos efeitos da urbanização da bacia, conforme previsto no PDDUAS.

\subsubsection{Pavimento permeável}

Para a simulação do cenário com pavimentos permeáveis, primeiro foi necessário fazer um dimensionamento do dispositivo para a tormenta de projeto. Para este estudo de caso, optou-se por dimensionar um sistema de infiltração total devido à precariedade da rede de microdrenagem existente. Portanto, considerando uma chuva de projeto com TR 10 e duração de 120 minutos, a intensidade média da precipitação será de $26,46 \mathrm{~mm} / \mathrm{h}$ e 0 volume total precipitado será de aproximadamente $52,92 \mathrm{~mm}$. Sendo o solo predominante da bacia hidrográfica do tipo $B$, tem-se que a taxa de infiltração média do solo é de $12,7 \mathrm{~mm} / \mathrm{h}$ (valor de referência da literatura, mas que pode superar significativamente este valor pra solos do tipo B), resultando em um volume de 27,52mm. Assim, sendo a brita 3 o material mais empregado para este tipo de camada de sub-base e sendo sua porosidade igual a $40 \%$, temos que a profundidade da camada de sub-base deve ser de aproximadamente $63,5 \mathrm{~mm}$. Esta profundidade é baixa porque foi utilizada uma chuva com um tempo de duração alto e por não haver áreas de contribuição externas para o pavimento permeável, ou seja, este drena apenas a precipitação que cai sobre o pavimento. Como o resultado do dimensionamento da camada de armazenamento do pavimento foi baixo, foi adotada uma profundidade de $150 \mathrm{~mm}$, correspondente à mínima espessura verificada em projetos semelhantes (ARAUJO; TUCCI; GOLDENFUM, 2000). 
Para a determinação da área de cada sub-bacia hidrográfica coberta por pavimentos permeáveis, considerou-se a área de todas as ruas adequadas à implantação deste dispositivo a partir do resultado do processo de álgebra de mapas. Os valores de área de pavimento permeável simulado em cada sub-bacia, bem como os novos valores recalculados dos parâmetros da bacia são apresentados na Tabela 12.

Tabela 12 - Dados do cenário de pavimentos permeáveis inseridos no SWMM

\begin{tabular}{cccccc} 
Sub-bacia & $\begin{array}{c}\text { Area de } \\
\text { pavimento } \\
\text { permeável } \\
\text { (ha) }\end{array}$ & $\begin{array}{c}\text { \% Area de } \\
\text { pavimento em } \\
\text { relação à área } \\
\text { das sub-bacias }\end{array}$ & $\begin{array}{c}\text { \% de área } \\
\text { impermeável } \\
\text { sem } \\
\text { armazenamento }\end{array}$ & $\begin{array}{c}\text { \% } \\
\text { Impermeável } \\
\text { atualizado }\end{array}$ & $\begin{array}{c}\text { Largura } \\
\text { atualizada } \\
\text { (m) }\end{array}$ \\
\hline $\mathbf{1}$ & 0,00 & 0,00 & 0,00 & 0,00 & 716,73 \\
\hline $\mathbf{2}$ & 0,00 & 0,00 & 0,00 & 0,00 & 630,50 \\
\hline $\mathbf{3}$ & 5,17 & 3,30 & 36,04 & 21,88 & 624,46 \\
\hline $\mathbf{4}$ & 0,63 & 1,08 & 49,29 & 11,45 & 316,89 \\
\hline $\mathbf{5}$ & 3,08 & 5,83 & 44,53 & 38,68 & 309,38 \\
\hline $\mathbf{6}$ & 0,67 & 0,54 & 59,02 & 12,37 & 554,47 \\
\hline $\mathbf{7}$ & 6,39 & 7,72 & 50,84 & 62,17 & 519,19 \\
\hline $\mathbf{8}$ & 6,09 & 4,10 & 68,08 & 31,31 & 600,92 \\
\hline $\mathbf{9}$ & 22,51 & 11,09 & 54,95 & 59,28 & 815,41 \\
\hline $\mathbf{1 0 . 1}$ & 22,52 & 6,26 & 39,42 & 34,58 & $1.162,86$ \\
\hline $\mathbf{1 0 . 2}$ & 39,71 & 25,31 & 56,33 & 43,65 & 976,82 \\
\hline $\mathbf{1 1}$ & 13,71 & 9,03 & 50,23 & 60,07 & $1.184,09$ \\
\hline $\mathbf{1 2}$ & 8,21 & 7,82 & 52,84 & 31,79 & 459,02 \\
\hline
\end{tabular}

Os dados das camadas do pavimento permeável usado no software encontramse na Tabela 13. Os telhados ocuparam uma área de aproximadamente $7,93 \%$ da área total da bacia hidrográfica do Gregório. Durante a operação do cenário de pavimentos permeáveis no SWMM, foi conduzida uma breve análise de sensibilidade da qual destacam-se como pontos importantes constatados: valor de declividade da superfície mostrou-se indiferente no desempenho do pavimento; permeabilidade de pavimento, que deve somente ser superior à permeabilidade do armazenamento para que não representa gargalo; índice de vazios (iv), que deve ser calculada através da equação porosidade = iv /(1+iv) e; taxa de infiltração, que é a taxa de infiltração da água no solo nativo. Todos os valores utilizados ou foram calculados ou obtidos em manuais técnicos (SÃO PAULO, 2012; FCTH, s.d.) e no manual do próprio SWMM (ROSSMAN, 2012). Entretanto, vale ressaltar que, após testes simples, verificou-se 
94

Avaliação do potencial de aplicação de técnicas compensatórias em áreas urbanas consolidadas

que o modelo praticamente não apresenta sensibilidade à parâmetros que não altura da camada de armazenamento, índice de vazios e taxas de infiltração. 
Tabela 13 - Dados de cada camada utilizada na simulação do pavimento permeável

\begin{tabular}{cccc}
\hline \multirow{2}{*}{ Camada } & Parâmetro & Unidade & Valor \\
& Armazenamento & $\mathrm{mm}$ & 0,00 \\
\multirow{3}{*}{ Superfície } & Volume de vegetação & $\%$ & 0,00 \\
& Rugosidade (n) & - & 0,10 \\
& Declividade & $\%$ & 1,00 \\
\hline \multirow{3}{*}{ Pavimento } & Espessura & $\mathrm{mm}$ & 150,00 \\
& Índice de vazios & - & 0,15 \\
& Parcela impermeável & $\%$ & 0,00 \\
& Permeabilidade & $\mathrm{mm} / \mathrm{hr}$ & 15,00 \\
& Fator de coagulação & - & 0,00 \\
& Espessura & $\mathrm{mm}$ & 0,00 \\
& Porosidade & $\%$ & - \\
\multirow{3}{*}{ Solo } & Capacidade de campo & $\mathrm{mm}$ & - \\
& Ponto de murcha & $\%$ & - \\
& Condutividade & $\mathrm{mm} / \mathrm{hr}$ & - \\
& Condutividade & $\%$ & - \\
& Sucção capilar & $\mathrm{mm}$ & - \\
\hline \multirow{3}{*}{ Armazenamento } & $\mathrm{mm}$ & 150,00 \\
& Altura da camada de armazenam. & - & 0,66 \\
& İndice de vazios & $\mathrm{mm} / \mathrm{hr}$ & 12,70 \\
& Taxa de infiltração & - & 0,00 \\
\hline \multirow{2}{*}{ Dreno } & Fator de colmatação & - & 0,00 \\
& Coeficiente de drenagem & - & - \\
& Expoente de drenagem & $\mathrm{mm}$ & - \\
\hline & Altura da tomada de água & &
\end{tabular}

\subsubsection{Jardins de chuva}

Conforme Autixier et al. (2014), jardins de chuva são comumente chamados de células de bioretenção, e a diferença entre os dispositivos é somente uma camada de armazenamento abaixo da camada de solo, existente apenas no segundo. Assim, para aumentar a eficiência dos controles LID na redução de escoamento superficial, os jardins de chuva utilizados neste trabalho correspondem àqueles com camada de armazenamento abaixo da camada de solo e que, no modelo SWMM, são chamados de células de bioretenção. Na inserção de jardins de chuva no modelo SWMM, foi necessário que se delimitasse as dimensões da superfície dos jardins de chuva para que se calculasse a área de cada sub-bacia coberta pelas estruturas (Tabela 14).

Com intuito de manter a função original do passeio público e pela impossibilidade de se desenvolver dupla função para jardins de chuva, estes devem ocupar espaço restrito junto às calçadas sem restringir o trânsito de pedestres ou carros. A área de estudos tem por características passeios estreitos e sem padronização, com a presença de degraus e obstáculos frequentes. Desta forma, as 
dimensões fixadas restringiram-se a 0,40 metros de largura por 25 metros de comprimento em cada rua apta a receber tais dispositivos, sendo um dispositivo para cada lado da rua. Optou-se também por utilizar a camada de armazenamento de 1 metro de profundidade preenchida pelo material granular brita 3. A dimensão de 1 metro foi escolhida para que houvesse espaço considerável para o armazenamento e infiltração da agua e não dificultasse demais o processo construtivo.

Tabela 14 - Dados para o cenário de jardins de chuva lineares

\begin{tabular}{ccccccc}
$\begin{array}{c}\text { Sub- } \\
\text { bacia }\end{array}$ & $\begin{array}{c}\text { Área de } \\
\text { jardins de } \\
\text { chuva (ha) }\end{array}$ & $\begin{array}{c}\text { \% Área de jardins em } \\
\text { relação à área das } \\
\text { sub-bacias }\end{array}$ & $\begin{array}{c}\text { \% de área } \\
\text { imperm. sem } \\
\text { armazenamento }\end{array}$ & $\begin{array}{c}\text { \% } \\
\text { Imperm. } \\
\text { atualizado }\end{array}$ & $\begin{array}{c}\text { Largura } \\
\text { atualizada } \\
\text { (m) }\end{array}$ & $\begin{array}{c}\text { Aimpermeável } \\
\text { direcionada } \\
\text { aos jardins } \\
\text { (ha) }\end{array}$ \\
\hline $\mathbf{1}$ & 0,08 & 0,00 & 0,00 & 0,00 & 716,73 & 24,84 \\
\hline $\mathbf{2}$ & 0,03 & 0,00 & 0,00 & 0,00 & 630,50 & 2,40 \\
\hline $\mathbf{3}$ & 0,174 & 0,05 & 36,04 & 25,18 & 624,46 & 23,36 \\
\hline $\mathbf{4}$ & 0,06 & 0,05 & 49,29 & 12,53 & 316,89 & 2,76 \\
\hline $\mathbf{5}$ & 0,196 & 0,33 & 44,53 & 44,51 & 309,38 & 40,24 \\
$\mathbf{6}$ & 0,216 & 0,05 & 59,02 & 12,91 & 554,47 & 37,92 \\
\hline $\mathbf{7}$ & 0,522 & 0,24 & 50,84 & 69,89 & 519,19 & 102,67 \\
\hline $\mathbf{8}$ & 0,822 & 0,15 & 68,08 & 35,41 & 600,92 & 161,28 \\
\hline $\mathbf{9}$ & 0,414 & 0,26 & 54,95 & 70,37 & 815,41 & 80,56 \\
\hline $\mathbf{1 0 . 1}$ & 0,408 & 0,16 & 39,42 & 40,84 & $1.162,86$ & 80,72 \\
\hline $\mathbf{1 0 . 2}$ & 0,394 & 0,12 & 56,32 & 68,96 & 976,82 & 74,51 \\
\hline $\mathbf{1 1}$ & 0,156 & 0,26 & 50,23 & 69,10 & $1.184,09$ & 25,34 \\
\hline $\mathbf{1 2}$ & 0,08 & 0,26 & 52,83 & 39,61 & 459,02 & 24,84 \\
\hline
\end{tabular}

Características de superfície, solo e armazenamento, foram obtidos junto ao próprio manual do usuário do software (Tabela 15), que fornece as recomendações de valores para cada camada segundo o tipo construtivo do dispositivo. Além disso, para espessuras de camadas, utilizou-se valores de referência fornecidos em trabalhos que propuseram valores ótimos para este tipo de dispositivo (ROSSMAN, 2010; AUTIXIER et al., 2014; DAVIS et al. 2009; MAILHOT et al. 2008). 
Tabela 15 - Dados de cada camada utilizada na simulação de jardins de chuva

\begin{tabular}{cccc}
\hline Camada & Parâmetro & Unidade & Valor \\
& Armazenamento & $\mathrm{mm}$ & 250,00 \\
Volume de vegetação & $\%$ & 0,00 \\
& Rugosidade (n) & - & 0,00 \\
Declividade & $\%$ & 0,00 \\
\hline \multirow{3}{*}{ Solo } & Espessura & $\mathrm{mm}$ & 1000,00 \\
& Porosidade & $\%$ & 0,437 \\
& Capacidade de campo & $\mathrm{mm}$ & 0,105 \\
& Ponto de murcha & $\%$ & 0,047 \\
& Condutividade & $\mathrm{mm} / \mathrm{hr}$ & 3,00 \\
& Condutividade & $\%$ & 10,00 \\
& Sucção capilar & $\mathrm{mm}$ & 2,40 \\
\hline \multirow{2}{*}{ Armazenamento } & $\mathrm{mm}$ & 1000,00 \\
& Altura da camada de armazenam. & - & 0,66 \\
& Índice de vazios & $\mathrm{mm} / \mathrm{hr}$ & 12,70 \\
& Taxa de infiltração & - & 0,00 \\
\hline
\end{tabular}

Novamente, após uma breve analise de sensibilidade, a resposta do modelo a alterações nos parâmetros das camadas dos controles LID foi insignificante, inclusive a alterações em parâmetros importantes como condutividade hidráulica de solos e porosidade. O modelo apresentou sensibilidade discreta apenas a alterações de espessura de camada de solo e altura de armazenamento que, em jardins de chuva, representa a lâmina de água acumulada sobre a superfície do terreno.

\subsubsection{Telhados verdes}

Na criação do cenário de telhados verdes partiu-se do princípio de que qualquer superfície reconhecida como telhado no mapa de uso e ocupação de solo poderia receber um telhado verde. Entretanto, como a realidade em campo não condiz com esta condição - devido, por exemplo, à telhados com declividade acentuada ou sem condições estruturais - e um cenário deste tipo estaria longe do que se pode considerar presumível, limitou-se a criação do cenário à condição de $25 \%$ dos telhados sendo telhados verdes. Assim, pode-se avaliar o quanto a quantidade de superfícies cobertas por este dispositivo influencia na vazão e volume de escoamento em um evento de precipitação. 
No dimensionamento de telhados verdes, não foram utilizados métodos analíticos para se obter a espessura da camada de solo. A espessura da camada de solo foi determinada de acordo com a classe do telhado verde. A saber, telhados verdes podem ser classificados em três tipos, intensivos, semi-extensivos, extensivos, baseados na espessura de sua camada de substrato. Os telhados intensivos possuem camadas de substrato superiores a $20 \mathrm{~cm}$, permitindo o crescimento de vegetação mais densa e até lenhosa - o que limita declividades e requer manutenção frequente e boa irrigação (MINKE, 2005). Além disso, exige reforço estrutural por acrescentar grande peso adicional ao telhado.

Telhados semi-extensivos possuem espessura de camada entre 12 e $25 \mathrm{~cm}$, o que limita o tipo de vegetação que pode ser aplicada, mas permite que o telhado atue de forma considerável na retenção de águas pluviais, além de exigir menos manutenção e irrigação e não exigir reforço estrutural de telhados convencionais para sua aplicação. Por fim, telhados verdes extensivos se caracterizam por substratos menos espessos, vegetação rasteira e camadas entre 2,5 e $15 \mathrm{~cm}$ de espessura evidentemente, não comportam raízes longas. Podem ser suportados por estruturas leves (mesmo quando saturados), exigindo pouca ou nenhuma manutenção (GETTER; ROWE, 2006; MINKE, 2005). Ao contrário dos intensivos, suportam apenas gramíneas e, caso não possuam estruturas reforçadas, só suportam trânsito para manutenção. São mais baratos, simples e praticáveis em vasta aplicação, exigindo menos manutenção.

Pelo apresentado, foram escolhidos para este estudo telhados com $15 \mathrm{~cm}$ de substrato por se entender que cumpririam a função para a qual foram designados controle de escoamento superficial - e que seriam apropriados para aplicação na área de estudos sem a modificação da estrutura original dos telhados e sem excessivas exigências de manutenção aos usuários.

Neste sentido, para a aplicação de telhados verdes em telhados convencionais utilizados na construção civil brasileira, a dificuldade maior está na declividade adotada na disposição das telhas, geralmente cerâmicas, instaladas entre $20 \%$ e 40\%. Em relação ao potencial de retenção de águas pluviais, VanWoert et al. (2005) afirmam que, embora haja diferenças entre os volumes retidos em diferentes declividades, todas as estruturas são eficazes no controle da geração de escoamento superficial. Apesar disso, é importante salientar que se deve priorizar a aplicação de telhados verdes nas declividades mais próximas a $2 \%$. 
Uma maneira de se verificar a capacidade de retenção de águas pluviais no substrato do telhado verde é utilizando-se a equação:

$$
P_{\text {inf }}=e . p
$$

Onde: Pinf é a altura pluviométrica infiltrada,

$e$ é a espessura do substrato e

$p$ a porosidade do substrato.

Assim, considerando-se a porosidade 0,437 (valor recomendado pelo manual do SWMM para solos tipo $\mathrm{B}$, semelhantes aos da área de estudos), tem-se que o telhado verde pode reter uma lâmina de quase 66 milímetros de precipitação, lâmina superior aos $52,92 \mathrm{~mm}$ da tormenta de projeto. Entretanto, devem ser consideradas as características do solo como umidade relativa e capacidade de campo. Os valores de área de telhados verdes inseridos no programa, bem como os valores recalculados dos parâmetros das sub-bacias encontram-se na Tabela 16.

Tabela 16 - Dados para o cenário de $25 \%$ dos telhados sendo telhados verdes

\begin{tabular}{cccccc} 
Sub-bacia & $\begin{array}{c}\text { Área de } \\
\text { telhados } \\
\text { verdes (ha) }\end{array}$ & $\begin{array}{c}\text { \% de área de } \\
\text { telhados nas sub- } \\
\text { bacias }\end{array}$ & $\begin{array}{c}\text { \% de área } \\
\text { impermeável } \\
\text { sem } \\
\text { armazenamento }\end{array}$ & $\begin{array}{c}\text { \% } \\
\text { Impermeável } \\
\text { atualizado }\end{array}$ & $\begin{array}{c}\text { Largura } \\
\text { atualizada } \\
\text { (m) }\end{array}$ \\
\hline $\mathbf{1}$ & 0,00 & 0,00 & 0,00 & 0,00 & 716,73 \\
\hline $\mathbf{2}$ & 0,00 & 0,00 & 0,00 & 0,00 & 630,50 \\
$\mathbf{3}$ & 3,55 & 2,27 & 12,35 & 22,91 & 631,13 \\
\hline $\mathbf{4}$ & 0,91 & 1,54 & 19,55 & 10,98 & 315,40 \\
\hline $\mathbf{5}$ & 2,62 & 4,96 & 16,71 & 39,56 & 312,26 \\
\hline $\mathbf{6}$ & 2,41 & 1,91 & 26,47 & 11,02 & 546,84 \\
\hline $\mathbf{7}$ & 7,36 & 8,88 & 20,54 & 61,00 & 512,64 \\
\hline $\mathbf{8}$ & 8,96 & 6,03 & 34,78 & 29,39 & 588,84 \\
\hline $\mathbf{9}$ & 20,18 & 9,94 & 23,37 & 62,40 & 825,95 \\
\hline $\mathbf{1 0 . 1}$ & 29,61 & 5,73 & 17,87 & 43,55 & $1.146,33$ \\
\hline $\mathbf{1 0 . 2}$ & 14,54 & 4,04 & 13,99 & 36,81 & $1.190,38$ \\
\hline $\mathbf{1 1}$ & 15,08 & 9,61 & 24,38 & 59,25 & $1.182,13$ \\
\hline $\mathbf{1 2}$ & 13,18 & 8,68 & 20,15 & 60,42 & $1.188,66$ \\
\hline
\end{tabular}


$\mathrm{Na}$ Tabela 17 encontram-se os dados das camadas utilizadas pelos telhados verdes, superfície, solo e manta de drenagem. Os dados de solo são semelhantes aos utilizados em jardins de chuva, pois considerou-se que será utilizado solo nativo no substrato dos telhados, já que estes possuem boa permeabilidade.

Tabela 17 - Parâmetros das camadas do controle LID telhado verde

\begin{tabular}{cccc}
\hline Camada & Parâmetro & Unidade & Valor \\
& Armazenamento & $\mathrm{mm}$ & 0,00 \\
Superfície & Volume de vegetação & $\%$ & 0,90 \\
& Rugosidade $(\mathrm{n})$ & - & 0,10 \\
& Declividade & $\%$ & 20,00 \\
\hline \multirow{2}{*}{ Solo } & Espessura & $\mathrm{mm}$ & 150,00 \\
& Porosidade & $\%$ & 0,437 \\
& Capacidade de campo & $\mathrm{mm}$ & 0,105 \\
& Ponto de murcha & $\%$ & 0,047 \\
& Condutividade & $\mathrm{mm} / \mathrm{hr}$ & 3,00 \\
& Condutividade & $\%$ & 10,00 \\
& Sucção capilar & $\mathrm{mm}$ & 2,40 \\
\hline \multirow{2}{*}{ Dreno } & Coeficiente de drenagem & - & 3,00 \\
(manta de drenagem) & Fração de vazios* & - & 0,50 \\
& Rugosidade $\mathrm{n}$ & $\mathrm{mm}$ & 0,10 \\
\hline
\end{tabular}

Embora existam diversos parâmetros para a representação das camas, Burszta-Adamiak e Mrowiec (2013), após comparações entre telhados verdes experimentais e os mesmos telhados simulados no SWWM, afirmam que o modelo não leva em conta parâmetros como rugosidade e declividade de superfície, além de ser bastante insensível a outros parâmetros como volume de vegetação e sucção capilar. Além disso, em simulações de eventos individuais, o modelo SWMM utiliza o parâmetro de capacidade de campo para determinar a umidade inicial do substrato de solo, não permitindo alterações. Desta forma, com os dados apresentados, o software considerou uma lâmina de água inicial de $7,05 \mathrm{~mm}$ já armazenada na camada de solo representando sua umidade, atualizando assim a capacidade de retenção dos telhados para $58,95 \mathrm{~mm}$. 


\subsubsection{Trincheiras de infiltração lineares}

O dispositivo trincheira de infiltração, no modelo SWMM, possui apenas a camada superficial e a camada de armazenamento da água, além da opção de possuir ou não um dreno, diferenciando assim modelos de infiltração total dos modelos de infiltração parcial. O dimensionamento foi realizado utilizando-se a chuva de projeto e as áreas de drenagem consideradas na locação das técnicas, ou seja, 6 hectares.

Para dimensionamento de trincheiras de infiltração, em geral, pode-se agrupar os métodos em 2 tipos, os métodos simplificados e os métodos fundamentados em modelos conceituais, como o método de PULS (BAPTISTA; NASCIMENTO; BARRAUD, 2005). Os métodos simplificados baseiam-se na hipótese de que a vazão de saída dos dispositivos é constante e, para a obtenção da dimensão dos dispositivos, mede-se a máxima diferença entre as curvas de volumes afluentes (baseado em curvas IDF) e volumes efluentes do dispositivo (baseado em drenos ou taxas de infiltração) (GOLDENFUM \& SILVEIRA, 2007).

Comumente, determina-se o comprimento e a largura das trincheiras com base no local de instalação. O comprimento pode ser fixado com base no traçado arquitetônico, já a largura depende mais de critérios técnicos construtivos, não devendo ser estreita de modo a dificultar sua construção e não larga demais a ponto de ocupar muito espaço do terreno e, por isso, a largura é um parâmetro determinado pelo projetista. Assim, a profundidade da trincheira prepondera como parâmetro único de dimensionamento, sendo os outros fixados pelo projetista.

Neste trabalho, foi usado o método de chuvas e, portanto, admitiu-se uma taxa de infiltração constante. Inicialmente fixou-se comprimento da trincheira como 100 metros, semelhante ao comprimento médio das ruas. Pela característica das ruas da área de estudos, que raramente superam 10 metros de largura, optou-se por uma largura de 0,8 metros localizada nas ruas junto às sarjetas. Assim, além de ocupar pouco espaço, dependendo do tipo de construção, o dispositivo poderia desempenhar ainda papel de área de estacionamento, não tirando a função da área original onde foi implantada. O passo seguinte foi o dimensionamento da profundidade.

Para efeito de simulação, considerou-se as trincheiras com 1 metro de profundidade para que facilitasse o processo construtivo e se mantivessem condições plausíveis de execução no cenário criado. Utilizando-se o método das chuvas para 
averiguação da capacidade de infiltração das trincheiras verificou-se que, para esta dimensão, o aceitável seria cerca de 2 hectares, sendo a área limite de 6 hectares bastante acima do recomendável. Apesar disso, visto que se pretende simular mais de uma técnica compensatória atuando em conjunto com as trincheiras e que, mesmo subdimensionadas, estas ainda exercem um papel importante no controle do escoamento, optou-se por manter as dimensões de 1 metro de profundidade, 0,8 metros de largura e 100 metros de comprimento. Além do mais, são raras as ruas com área de drenagem próximas a 6 hectares.

Para a simulação das trincheiras, foi necessária a determinação das áreas tratadas por trincheiras em cada uma das 13 sub-bacias hidrográficas do trabalho. As sub-bacias 1 e 2, por serem praticamente rurais, não receberam trincheiras.

$\mathrm{Na}$ inserção das trincheiras no modelo SWMM, a área das trincheiras se deu pela soma do comprimento total das ruas aptas a receber os dispositivos e, a partir disso, supôs-se uma largura de 0,8m nas trincheiras em cada lado da rua. Em seguida, foram realizados os cálculos para a inserção dos dispositivos no modelo SWMM respeitando-se todas as exigências de adequação de parâmetros das sub-bacias como, por exemplo, área impermeável e largura de escoamento. Além disso, foi feito um levantamento manual que levou a uma estimativa da área de cada bacia tratada pelos dispositivos baseado no mapa de adequabilidade e no comprimento total das trincheiras em cada bacia. Os dados conforme inseridos encontram-se na Tabela 18.

Tabela 18 - Dados de sub-bacias para o cenário de trincheiras de infiltração lineares

\begin{tabular}{|c|c|c|c|c|c|c|}
\hline Sub-bacia & $\begin{array}{c}\text { Área das } \\
\text { trincheira } \\
\text { s (ha) }\end{array}$ & $\begin{array}{c}\% \text { área de } \\
\text { trincheiras } \\
\text { nas sub- } \\
\text { bacias }\end{array}$ & $\begin{array}{c}\text { \% de área } \\
\text { impermeável } \\
\text { sem } \\
\text { armazenamento }\end{array}$ & $\begin{array}{c}\% \\
\text { Impermeável } \\
\text { atualizado }\end{array}$ & $\begin{array}{l}\text { Largura } \\
\text { atualiz. } \\
\qquad(\mathrm{m})\end{array}$ & $\begin{array}{c}\text { Aimpermeável } \\
\text { direcionada às } \\
\text { trincheiras (ha) }\end{array}$ \\
\hline 1 & 0,00 & 0,00 & 0,00 & 0,00 & 716,73 & 0,00 \\
\hline 2 & 0,00 & 0,00 & 0,00 & 0,00 & 630,50 & 0,00 \\
\hline 3 & 0,22 & 0,14 & 36,24 & 25,03 & 645,21 & 9,20 \\
\hline 4 & 0,00 & 0,00 & 49,29 & 12,52 & 320,34 & 0,00 \\
\hline 5 & 0,71 & 1,34 & 45,91 & 43,17 & 325,79 & 11,00 \\
\hline 6 & 0,08 & 0,07 & 59,32 & 12,84 & 557,24 & 0,71 \\
\hline 7 & 1,18 & 1,43 & 51,90 & 68,45 & 557,59 & 33,81 \\
\hline 8 & 0,90 & 0,61 & 69,27 & 34,80 & 624,22 & 29,05 \\
\hline 9 & 3,72 & 1,83 & 56,37 & 68,53 & 906,57 & 99,30 \\
\hline 10.1 & 4,14 & 1,15 & 39,68 & 47,30 & 1209,95 & 56,80 \\
\hline 10.2 & 3,52 & 2,24 & 66,71 & 40,38 & 1232,94 & 100,00 \\
\hline 11 & 2,95 & 1,94 & 67,15 & 57,92 & 1292,37 & 72,37 \\
\hline
\end{tabular}




\begin{tabular}{ccccccc}
12 & 1,63 & 1,55 & 38,05 & 51,02 & 1292,88 & 19,30 \\
\hline \multicolumn{2}{l}{ Os valores inseridos no } & modelo para representação das trincheiras de
\end{tabular}
infiltração encontram-se na Tabela 19.

Tabela 19 - Valores das camadas das trincheiras de infiltração utilizados na simulação

\begin{tabular}{cccc}
\hline Camada & Parâmetro & Unidade & Valor \\
& Armazenamento & $\mathrm{mm}$ & 0,00 \\
\multirow{3}{*}{ Superfície } & Volume de vegetação & $\%$ & 0,00 \\
& Rugosidade (n) & - & 0,10 \\
& Declividade & $\%$ & 1,00 a 5,00 \\
\hline \multirow{3}{*}{ Armazenamento } & Altura da camada de armazenam. & $\mathrm{mm}$ & 1000,00 \\
& Índice de vazios & - & 0,66 \\
& Taxa de infiltração & $\mathrm{mm} / \mathrm{hr}$ & 12,70 \\
& Fator de colmatação & - & 0,00 \\
\hline \multirow{2}{*}{ Dreno } & Coeficiente de drenagem & - & 0,00 \\
& Expoente de drenagem & - & 0,00 \\
& Altura da tomada de água & $\mathrm{mm}$ & 0,00 \\
\hline
\end{tabular}

\subsubsection{Microreservatórios individuais}

No cenário de microreservatórios individuais, a simulação se deu considerando que uma parcela dos telhados identificados no processo de sensoriamento remoto teria seu escoamento retido por cisternas. Como o planejamento prevê a implantação de cisternas em residências já existentes, dificilmente se dispõe de espaço para cisternas de mais de $1 \mathrm{~m}^{3} \mathrm{e}$, por isso, este foi considerado o tamanho das cisternas da área de estudos.

Em verificações feitas na imagem de satélite, registrou-se que os telhados residenciais da área de estudos mantêm-se, usualmente, entre $80 \mathrm{~m}^{2}$ e $160 \mathrm{~m}^{2}$, dependendo do tipo da residência. Assim, optou-se por adotar um telhado padrão de $120 \mathrm{~m}^{2}$ para o cálculo do número de cisternas a serem implantadas e, tal qual o cenário de telhados verdes, o cenário foi montado com um quarto dos telhados de residências possuindo cisternas de $1 \mathrm{~m}^{3}$ instaladas. Com estes valores, foi possível estimar a quantidade cisternas a partir da área total de telhados de cada sub-bacia e do valor médio de $120 \mathrm{~m}^{2}$ de telhado por residência. Os dados inseridos no software são apresentados na Tabela 20. 
Tabela 20 - Dados das sub-bacias para o cenário de microreservatórios individuais

\begin{tabular}{cccc} 
Sub-bacia & $\begin{array}{c}\text { Número total de } \\
\text { cisternas (unidade) }\end{array}$ & $\begin{array}{c}\text { Area da bacia } \\
\text { drenada } \\
\left(\mathbf{m}^{2}\right)\end{array}$ & $\begin{array}{c}\text { Area impermeável } \\
\text { da bacia drenada } \\
(\%)\end{array}$ \\
\hline $\mathbf{1}$ & 0 & 0 & 0,00 \\
$\mathbf{2}$ & 0 & 0 & 0,00 \\
$\mathbf{4}$ & 296 & $35.537,93$ & 9,01 \\
\hline $\mathbf{5}$ & 76 & $9.147,62$ & 12,32 \\
$\mathbf{6}$ & 218 & $26.178,12$ & 11,13 \\
\hline $\mathbf{7}$ & 200 & $24.094,43$ & 14,77 \\
$\mathbf{8}$ & 613 & $73.611,00$ & 12,71 \\
\hline $\mathbf{9}$ & 746 & $89.582,12$ & 17,02 \\
$\mathbf{1 0 . 1}$ & 1.682 & $201.840,43$ & 14,12 \\
\hline $\mathbf{1 0 . 2}$ & 1.211 & $145.392,25$ & 9,90 \\
\hline $\mathbf{1 1}$ & 1.256 & $150.753,25$ & 13,93 \\
\hline $\mathbf{1 2}$ & 1.098 & $131.809,62$ & 12,56 \\
\hline
\end{tabular}

Os microreservatórios individuais considerados na simulação são cisternas simples e possuem apenas a camada de armazenamento e o dreno. No modelo, a determinação do volume de cada cisterna ocorre pela inserção da área de cada unidade e da altura de armazenamento $\left(1 \mathrm{~m}^{2}\right.$ de área e $1000 \mathrm{~mm}$ de armazenamento, neste caso). Os valores dos parâmetros das camadas do controle LID utilizados no cenário são apresentados na Tabela 21.

Tabela 21 - Dados do controle LID utilizados na modelagem

\begin{tabular}{cccc} 
Camada & Parâmetro & Unidade & Valor \\
\cline { 2 - 4 } Armazenamento & Altura da camada de armazenam. & $\mathrm{mm}$ & 1000,00 \\
& Índice de vazios & - & - \\
& Taxa de infiltração & $\mathrm{mm} / \mathrm{hr}$ & - \\
& Fator de colmatação & - & - \\
\hline \multirow{2}{*}{ Dreno } & Coeficiente de drenagem & - & 1,00 \\
& Expoente de drenagem & - & 1,00 \\
& Altura da tomada de água & $\mathrm{mm}$ & 1000,00 \\
\hline
\end{tabular}




\subsubsection{Cenário final}

No final da etapa de simulação hidrológica, as técnicas compensatórias que apresentaram melhores resultados individuais no combate ao escoamento superficial compuseram um cenário no qual foram avaliadas trabalhando em conjunto. As técnicas compensatórias que foram analisadas para compor este cenário final foram as bacias de detenção, os pavimentos permeáveis, os jardins de chuva, os telhados verdes, as trincheiras de infiltração e os microreservatórios individuais, e seus desempenhos foram obtidos nos resultados de seus respectivos cenários individuais.

Para que a simulação pudesse ocorrer de maneira adequada com o uso simultâneo de diversas técnicas compensatórias, algumas adaptações e considerações tiveram que ser feitas no projeto para inserção no software. Como foram simuladas técnicas compensatórias pontuais, centralizadas e lineares, foi necessária atenção especial na criação do cenário no SWMM para que a o arranjo espacial dos dispositivos fosse respeitada e para que a simulação considerasse a ordem correta do fluxo de água. Portanto, uma adaptação no modo de trabalho no software foi feita para que se pudesse simular o cenário final conforme desejado, uma vez que o modelo, apesar de aceitar mais de um tipo de LID em uma bacia hidrográfica, somente simula as técnicas trabalhando paralelamente, conforme a Figura 30.

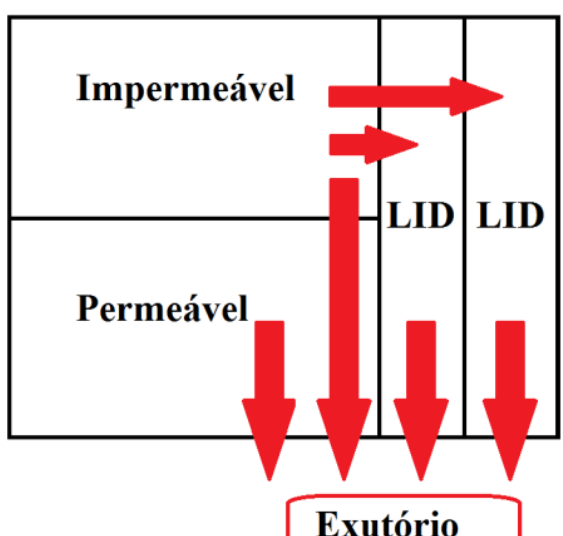

Figura 30 - Representação de uma bacia hidrográfica com mais de um tipo de LID no SWMM

Visto isso, foi desenvolvida uma adaptação da representação da bacia no SWMM para que se viabilizasse a simulação conforme se planejou no cenário, com as técnicas compensatórias funcionando paralelamente e linearmente. A saber, 
quando representadas em paralelo no software, os controles LID podem tratar a água que incide sobre elas e também escoamento direcionado a elas a partir de áreas impermeáveis externas, não sendo possível que o escoamento efluente de uma LID seja direcionado a outra LID ou que estas tratem escoamento oriundo de áreas permeáveis. Assim, se houver mais de uma LID em uma sub-bacia, o escoamento efluente das LID será direcionado para o exutório da bacia de modo paralelo, conforme representado na Figura 30.

Entretanto, pela forma como o SWMM representa uma bacia hidrográfica, com porções impermeáveis e permeáveis trabalhando isoladamente, é possível que se represente uma sub-bacia através de duas diferentes sub-bacias derivadas desta, uma exclusivamente permeável e outra exclusivamente impermeável, conforme a Figura 31. Desta forma, o escoamento das duas sub-bacias derivadas pode se somar em um ponto comum na rede de drenagem que representará o exutório da sub-bacia dividida. Para facilitar a compreensão do texto, o processo de divisão de sub-bacias será chamado de "desmembramento" e as sub-bacias derivadas serão chamadas de "parcelas" que poderão ser "mistas" (compostas por áreas permeáveis e impermeáveis) ou "dedicadas" (compostas exclusivamente por áreas permeáveis, impermeáveis ou LID).
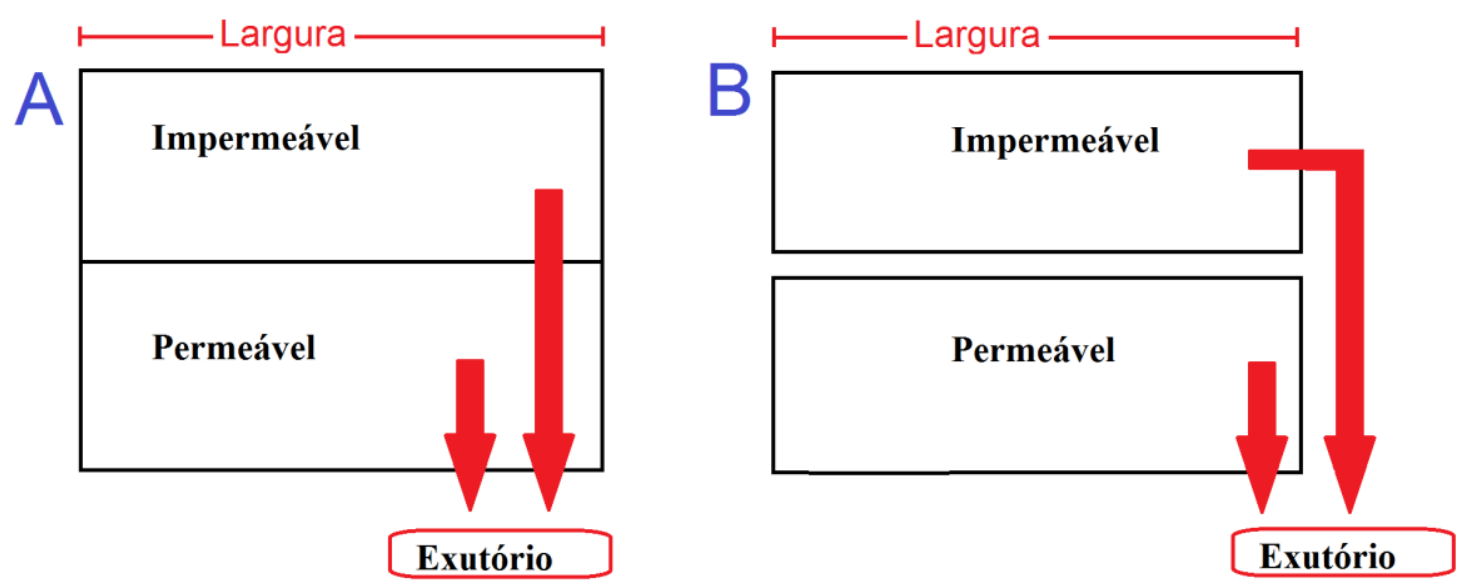

Figura 31 - (A) Representação de uma bacia hidrográfica mista da maneira convencional e (B) desmembramento da bacia em duas parcelas dedicadas no modelo SWMM

Analisando-se a representação apresentada na Figura 31, percebe-se que, da mesma maneira que uma bacia hidrográfica comum pode ser desmembrada em duas parcelas, uma bacia hidrográfica com técnicas compensatórias também pode ser desmembrada em três parcelas dedicadas, desde que se preserve a maneira como o 
software representa o escoamento. Isso é possível pois o SWMM permite que o exutório de uma bacia hidrográfica seja ou um nó ou outra bacia, permitindo então que o escoamento de uma parcela possa ser direcionado a outra parcela criada especificamente para a representação das LID. Porém, uma vez que a representação de bacias hidrográficas com controles LID ocorre com o escoamento da porção impermeável sendo direcionado de forma dividida para duas ou mais porções da subbacia - conforme pode ser visto na Figura 10 e na Figura 30 - o desmembramento de uma sub-bacia com mais de uma LID no SWMM requereria várias parcelas para que representasse a sub-bacia original de maneira correta, podendo as parcelas serem mistas ou dedicadas.

Como exemplo, pode ser citada uma bacia hidrográfica com apenas uma LID na qual metade do escoamento superficial gerado na porção impermeável é direcionado à LID e a outra metade é direcionado ao exutório. Esta bacia poderia ser representada por, pelo menos, três maneiras diferentes: apenas com parcelas dedicadas; com parcelas mistas e dedicadas e; por diferentes parcelas mistas, conforme apresentado na Figura 32.
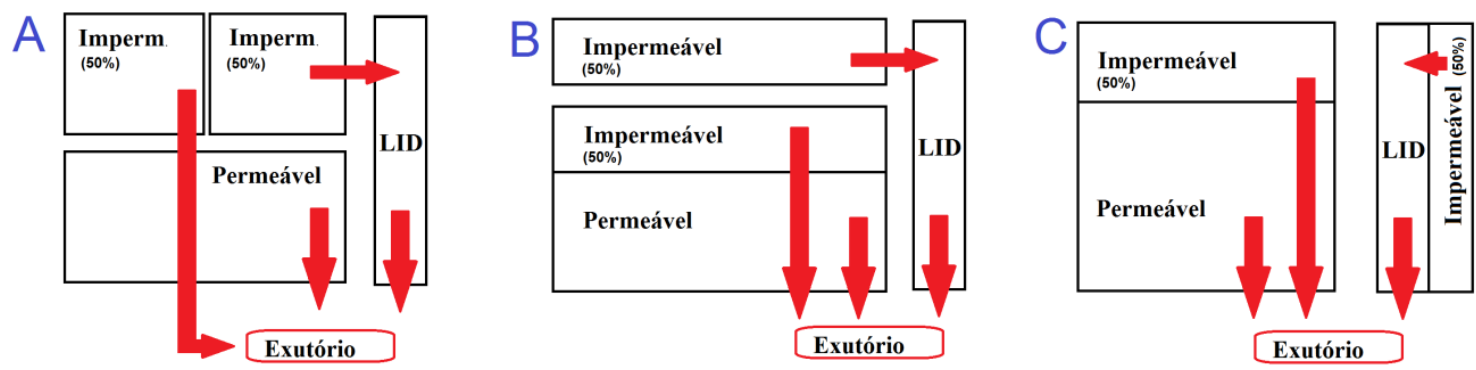

Figura 32 - (A) Representação de uma bacia hidrográfica com LID apenas por parcelas dedicadas; (B) representação da bacia por parcelas dedicadas e; (C) representação da bacia apenas por parcelas mistas no modelo SWMM

Desde que todos os parâmetros hidrológicos das parcelas sejam calculados corretamente, qualquer umas das três representações é coerente e gera os mesmos resultados, o que foi confirmado através de testes no modelo em que as três apresentaram valores idênticos de hidrogramas. É importante destacar que, para cada uma das três representações ( $A, B$ ou $C$ ), os valores dos parâmetros de cada parcela diferirão entre si, apesar das três situações representarem uma mesma bacia hidrográfica. Apesar de mais complexa e trabalhosa, a representação de bacias hidrográficas desmembradas torna o modelo SWMM mais versátil e permite a 
reprodução de praticamente qualquer configuração desejada de bacias hidrográficas e sua interação com controles LID, dependendo apenas do engenho do operador e do cuidado no cálculo e adaptação dos parâmetros hidrológicos das bacias.

A viabilização da simulação conjunta das diferentes técnicas compensatórias é de fundamental importância para o planejamento da bacia, uma vez que o resultado do funcionamento das técnicas em conjunto pode diferir drasticamente do que se imagina do resultado, uma simples somatória dos efeitos de cada técnica (MIGUEZ et al., 2009). Dito isto, buscando-se viabilizar a representação de técnicas compensatórias pontuais, lineares e centralizadas no mesmo modelo, criou-se uma configuração padrão de representação de sub-bacias hidrográficas para que fosse utilizada no cenário final da simulação hidrológica. Assim, a configuração apresentada na Figura 33 foi aquela utilizada na montagem do cenário final com as técnicas compensatórias trabalhando em conjunto no controle do escoamento.

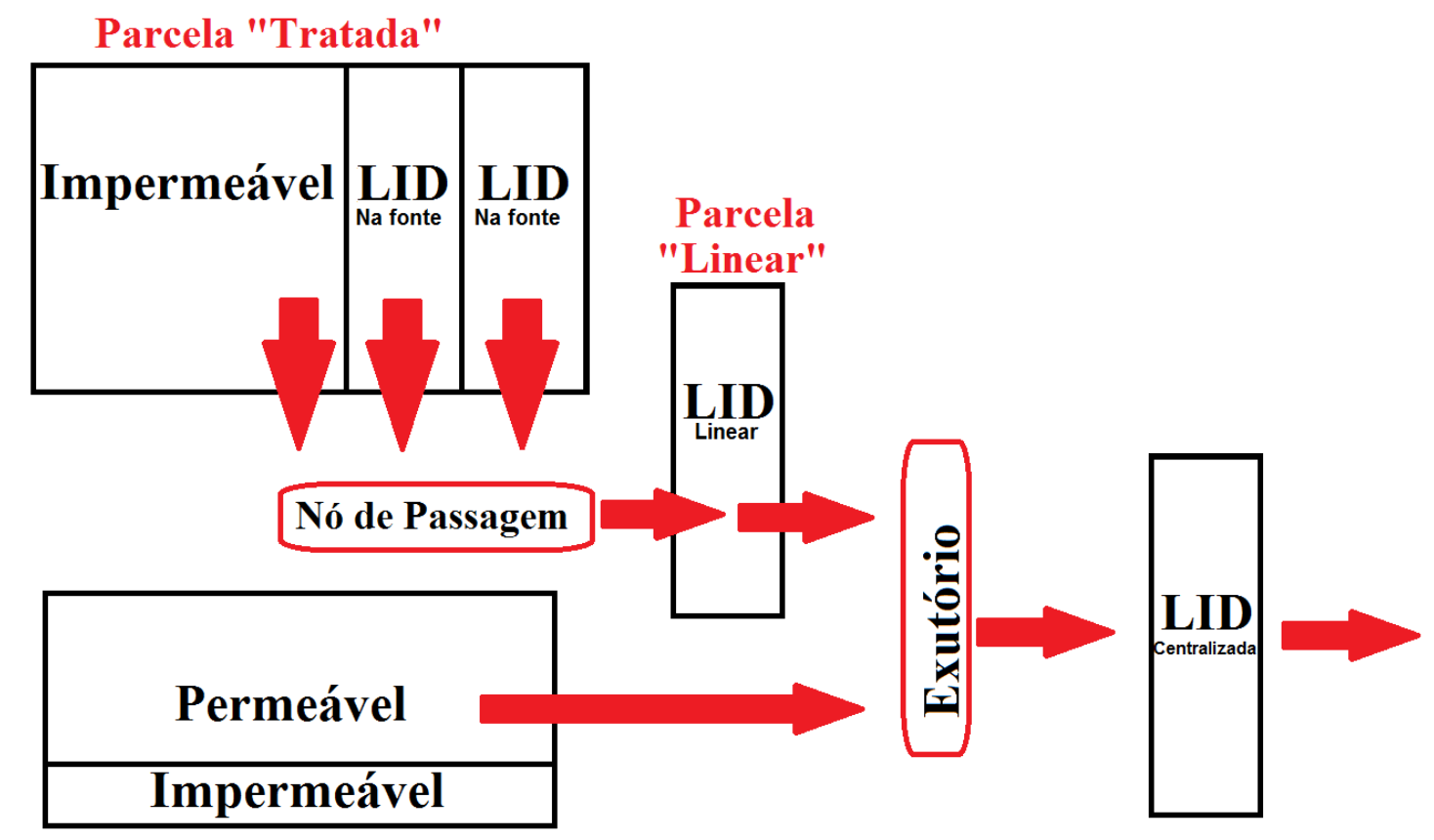

Parcela "Livre"

Figura 33 - Representação de uma bacia hidrográfica com técnicas compensatórias na fonte, lineares e centralizadas funcionando em conjunto no modelo SWMM

$\mathrm{Na}$ configuração apresentada na Figura 33 , os três tipos de técnicas compensatórias - na fonte, lineares e centralizadas - podem ser inseridas simultaneamente em uma bacia hidrográfica através de parcelas que permitem que sejam simuladas trabalhando em conjunto. Para isto, cada sub-bacia foi representada por pelo menos 3 parcelas que receberam a seguinte denominação: Tratada, 
representada pela parcela composta pelas áreas exclusivamente impermeáveis que recebem tratamento de controles LID paralelos e lineares; Linear, composta pelas LID lineares que recebem o escoamento efluente da parcela Tratada e; Livre, para a parcela mista composta pela área permeável e pela parte impermeável que não recebe tratamento algum por controles LID.

Esta configuração permite a representação de praticamente qualquer configuração de disposição de controles LID, permitindo a variação do número de técnicas dos três tipos (como a inserção de duas técnicas lineares ligadas em série ou paralelo, por exemplo) e mostrou-se coerente em todas as simulações realizadas no trabalho.

Para a montagem do cenário final, uma vez que do ponto de vista pragmático seria pouco provável o uso de todas as 7 técnicas compensatórias analisadas trabalhando em conjunto, foram consideradas somente as técnicas que apresentaram os melhores resultados individuais que, como será verificado nos capítulos subsequentes, foram os pavimentos permeáveis, os telhados verdes, as trincheiras de infiltração e as bacias de detenção. As áreas e dimensões das técnicas compensatórias usadas no cenário final foram baseadas nos valores utilizados nas simulações dos cenários individuais e podem ser verificadas na Tabela 22. Entretanto, a área ocupada por trincheiras de infiltração foi descontada da área de pavimentos permeáveis em casos onde a rua possuía os dois dispositivos.

Pela configuração das parcelas de cada sub-bacia na simulação, as trincheiras de infiltração recebem o escoamento superficial excedente de todos os telhados verdes, todos os pavimentos permeáveis e da parcela de áreas impermeáveis tratada pelos dispositivos, obtida após análise dos mapas de adequabilidade. As bacias de detenção não são contempladas nas parcelas de cada sub-bacia pois fazem parte da modelagem hidráulica do SWMM. Desta forma, a inserção dos dispositivos ocorre na rede de macrodrenagem do modelo. 
Avaliação do potencial de aplicação de técnicas compensatórias em áreas urbanas consolidadas

Tabela 22 - Dados das parcelas das sub-bacias utilizados na criação do cenário final

\begin{tabular}{|c|c|c|c|c|c|c|c|c|}
\hline $\begin{array}{c}\text { Parcelas das } \\
\text { bacias }\end{array}$ & $\begin{array}{l}\text { Área } \\
\text { (ha) }\end{array}$ & $\begin{array}{l}\text { Área \% } \\
\text { do total }\end{array}$ & $\begin{array}{l}\text { LID telhados } \\
\text { verdes (ha) }\end{array}$ & $\begin{array}{l}\text { LID } \\
\text { pavimento } \\
\text { permeável } \\
\text { (ha) }\end{array}$ & CN & $\begin{array}{l}\text { \% da área } \\
\text { imp. da } \\
\text { sub-bacia }\end{array}$ & Largura & $\begin{array}{l}\text { \%imp. da } \\
\text { parcela }\end{array}$ \\
\hline 1 Tratada & 0,00 & 0,00 & 0,00 & 0,00 & 98,00 & 0,00 & 0,00 & 0,00 \\
\hline 1 Linear & 0,00 & 0,00 & 0,00 & 0,00 & 98,00 & 0,00 & 0,00 & 0,00 \\
\hline 1 Livre & 164,85 & 100,00 & 0,00 & 0,00 & 65,29 & 0,00 & 630,50 & 0,00 \\
\hline 2 Tratada & 0,00 & 0,00 & 0,00 & 0,00 & 98,00 & 0,00 & 0,00 & 0,00 \\
\hline 2 Linear & 0,00 & 0,00 & 0,00 & 0,00 & 98,00 & 0,00 & 0,00 & 0,00 \\
\hline 2 Livre & 120,49 & 100,00 & 0,00 & 0,00 & 64,39 & 0,00 & 630,50 & 0,00 \\
\hline 3 Tratada & 15,67 & 10,00 & 3,55 & 4,95 & 98,00 & 23,18 & 643,24 & 100,00 \\
\hline 3 Linear & 0,22 & 0,14 & 0,00 & 0,00 & 98,00 & 0,14 & 2,00 & 100,00 \\
\hline 3 Livre & 140,78 & 89,86 & 0,00 & 0,00 & 81,21 & 76,68 & 643,24 & 16,73 \\
\hline 4 Tratada & 1,55 & 2,62 & 0,91 & 0,64 & 98,00 & 0,00 & 311,93 & 100,00 \\
\hline 4 Linear & 0,00 & 0,00 & 0,00 & 0,00 & 98,00 & 0,00 & 0,00 & 100,00 \\
\hline 4 Livre & 57,71 & 97,38 & 0,00 & 0,00 & 66,10 & 100,00 & 311,93 & 10,18 \\
\hline 5 Tratada & 13,31 & 25,19 & 2,62 & 2,37 & 98,00 & 45,36 & 293,13 & 100,00 \\
\hline 5 Linear & 0,71 & 1,34 & 0,00 & 0,00 & 98,00 & 1,34 & 0,44 & 100,00 \\
\hline 5 Livre & 38,81 & 73,47 & 0,00 & 0,00 & 77,15 & 53,30 & 288,72 & 24,47 \\
\hline 6 Tratada & 15,32 & 12,13 & 2,41 & 0,59 & 98,00 & 42,83 & 507,98 & 100,00 \\
\hline 6 Linear & 0,08 & 0,07 & 0,00 & 0,00 & 98,00 & 0,07 & 0,03 & 100,00 \\
\hline 6 Livre & 110,91 & 87,80 & 0,00 & 0,00 & 80,81 & 57,10 & 507,98 & 14,79 \\
\hline 7 Tratada & 15,32 & 12,13 & 2,41 & 0,59 & 98,00 & 42,83 & 507,98 & 100,00 \\
\hline 7 Linear & 0,08 & 0,07 & 0,00 & 0,00 & 98,00 & 0,07 & 0,03 & 100,00 \\
\hline 7 Livre & 110,91 & 87,80 & 0,00 & 0,00 & 80,81 & 57,10 & 507,98 & 14,79 \\
\hline 8 Tratada & 34,85 & 23,44 & 8,96 & 5,19 & 98,00 & 54,47 & 563,14 & 100,00 \\
\hline 8 Linear & 0,90 & 0,61 & 0,00 & 0,00 & 98,00 & 0,61 & 0,38 & 100,00 \\
\hline 8 Livre & 112,88 & 75,95 & 0,00 & 0,00 & 67,04 & 44,92 & 563,14 & 14,95 \\
\hline 9 Tratada & 108,59 & 53,46 & 20,18 & 18,79 & 98,00 & 67,62 & 724,31 & 100,00 \\
\hline 9 Linear & 3,72 & 1,83 & 0,00 & 0,00 & 98,00 & 1,83 & 1,68 & 100,00 \\
\hline 9 Livre & 90,81 & 44,71 & 0,00 & 0,00 & 81,69 & 30,55 & 724,31 & 33,72 \\
\hline 10.1 Tratada & 79,10 & 21,99 & 14,54 & 18,38 & 98,00 & 40,89 & $1.112,73$ & 100,00 \\
\hline 10.1 Linear & 4,14 & 1,15 & 0,00 & 0,00 & 98,00 & 1,15 & 1,43 & 100,00 \\
\hline 10.1 Livre & 276,50 & 76,86 & 0,00 & 0,00 & 73,83 & 57,96 & 1112,73 & 23,03 \\
\hline 10.2 Tratada & 104,60 & 66,65 & 15,08 & 36,19 & 98,00 & 97,56 & 851,24 & 100,00 \\
\hline 10.2 Linear & 3,52 & 2,24 & 0,00 & 0,00 & 98,00 & 2,24 & 2,93 & 100,00 \\
\hline 10.2 Livre & 48,82 & 31,11 & 0,00 & 0,00 & 73,47 & 0,20 & 851,24 & 0,20 \\
\hline 11 Tratada & 77,73 & 51,17 & 13,18 & 10,76 & 98,00 & 66,96 & $1.071,18$ & 100,00 \\
\hline 11 Linear & 2,95 & 1,94 & 0,00 & 0,00 & 98,00 & 1,94 & 2,53 & 100,00 \\
\hline 11 Livre & 71,22 & 46,89 & 0,00 & 0,00 & 80,34 & 31,10 & 1071,18 & 34,09 \\
\hline 12 Tratada & 25,00 & 23,80 & 5,50 & 6,58 & 98,00 & 44,76 & 433,01 & 100,00 \\
\hline 12 Linear & 1,63 & 1,55 & 0,00 & 0,00 & 98,00 & 1,55 & 0,77 & 100,00 \\
\hline 12 Livre & 78,44 & 74,65 & 0,00 & 0,00 & 72,91 & 53,69 & 433,01 & 19,11 \\
\hline
\end{tabular}




\section{Resultados e Discussão}

Neste capítulo, os resultados são apresentados conforme a sequência apresentada no capítulo sobre materiais e métodos.

\subsection{CLASSIFICAÇÃO DO USO E OCUPAÇÃO DO SOLO NA BACIA}

Utilizando os softwares Definiens Developer e ArcGIS, foi desenvolvido o mapa de uso e ocupação do solo (Figura 34).

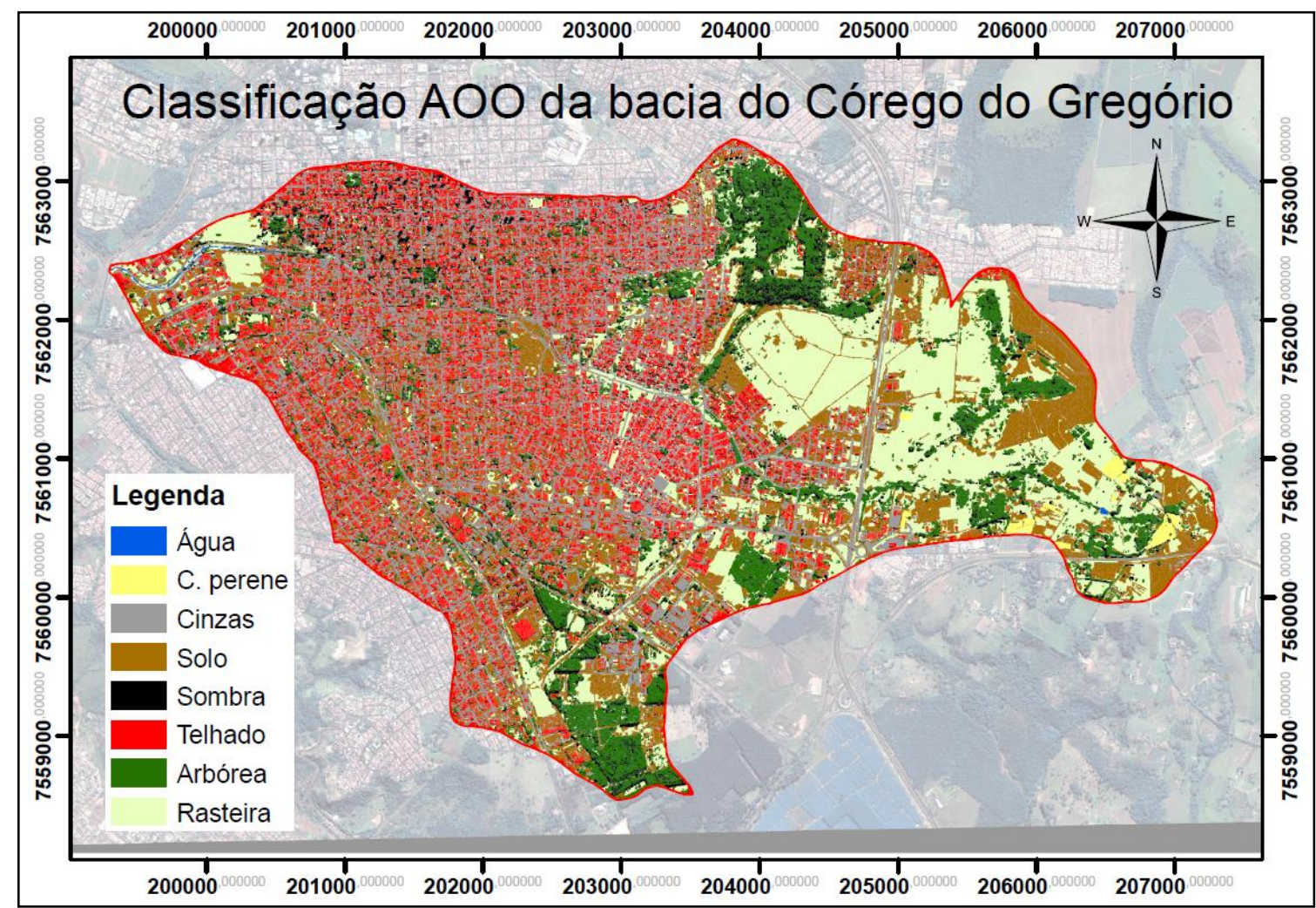

Figura 34 - Classificação do uso e ocupação do solo por análise orientada a objetos

A Figura 34 é resultado da técnica de classificação supervisionada de imagens chamada Análise Orientada a Objetos (AOO). No mapa classificou-se a imagem nas 8 classes solo pré-determinadas: Água, Culturas Perenes, Cinza (asfalto e concreto), Solo exposto, Sombras, Telhados, Vegetação Arbórea e Vegetação rasteira. Desta maneira, este produto fornece informações importantes da área de estudo não só para 
este trabalho como para outros estudos que possam ser realizados na mesma região. Os dados de área de cada cobertura, em hectares, estão apresentados na Tabela 23.

Tabela 23 - Valores de áreas, em hectares e percentuais, de cada classe de solo da área de estudos

\begin{tabular}{|c|c|c|c|c|c|c|c|c|c|c|c|c|c|c|c|}
\hline $\begin{array}{l}\text { Sub- } \\
\text { bacia }\end{array}$ & Arb & & Ras & & Telh & & & & & & Son & & Per & & $\begin{array}{l}\text { Area } \\
\text { total }\end{array}$ \\
\hline & (ha) & $\%$ & (ha) & $\%$ & (ha) & $\%$ & (ha) & $\%$ & (ha) & $\%$ & (ha) & $\%$ & (ha) & $\%$ & (ha) \\
\hline 1 & 45,55 & 27,6 & 73,46 & 44,6 & - & - & 3,06 & 1,9 & 35,17 & 21,3 & - & - & 7,61 & 4,6 & 164,85 \\
\hline 2 & 34,12 & 28,3 & 58,24 & 48,3 & - & - & 1,39 & 1,2 & 26,73 & 22,2 & - & - & - & - & 120,49 \\
\hline 3 & 28,54 & 18,2 & 57,55 & 36,7 & 14,22 & 9,1 & 25,23 & 16,1 & 22,82 & 14,6 & 8,31 & 5,3 & - & - & 156,67 \\
\hline 4 & 2,80 & 4,7 & 43,75 & 73,8 & 3,66 & 6,2 & 3,76 & 6,3 & 4,18 & 7,1 & 1,11 & 1,9 & - & - & 59,26 \\
\hline 5 & 6,59 & 12,4 & 12,70 & 24,0 & 10,47 & 19,8 & 13,05 & 24,7 & 5,75 & 10,9 & 4,27 & 8,1 & - & - & 52,83 \\
\hline 6 & 26,10 & 20,6 & 65,69 & 52,0 & 9,64 & 7,6 & 6,69 & 5,3 & 12,19 & 9,7 & 6,02 & 4,8 & - & - & 126,32 \\
\hline 7 & 6,13 & 7,4 & 6,61 & 8,0 & 29,44 & 35,5 & 28,47 & 34,4 & 3,50 & 4,2 & 8,71 & 10,5 & - & - & 82,87 \\
\hline 8 & 59,20 & 39,8 & 22,12 & 14,9 & 35,83 & 24,1 & 16,80 & 11,3 & 4,99 & 3,4 & 9,69 & 6,5 & - & - & 148,63 \\
\hline 9 & 23,78 & 11,7 & 7,05 & 3,5 & 80,74 & 39,7 & 66,20 & 32,6 & 7,86 & 3,9 & 17,50 & 8,6 & - & - & 203,13 \\
\hline 10.1 & 82,42 & 22,8 & 76,55 & 21,2 & 58,16 & 16,1 & 89,37 & 24,7 & 25,74 & 7,1 & 28,25 & 7,8 & - & - & 361,31 \\
\hline 10.2 & 15,89 & 10,2 & 9,09 & 5,9 & 60,30 & 38,8 & 46,76 & 30,1 & 7,31 & 4,7 & 15,89 & 10,2 & - & - & 155,26 \\
\hline 11 & 21,19 & 13,9 & 5,19 & 3,4 & 52,72 & 34,7 & 52,24 & 34,4 & 3,34 & 2,2 & 17,21 & 11,3 & - & - & 151,90 \\
\hline 12 & 20,80 & 2,8 & 26,50 & 3,6 & 21,99 & 3,0 & 19,63 & 2,7 & 6,55 & 0,9 & 9,61 & 1,3 & - & - & 105,07 \\
\hline Total & 373,1 & 19,8 & 464,6 & 24,6 & 377,1 & 20,0 & 372,6 & 19,7 & 166,1 & 8,8 & 126,5 & 6,7 & 7,61 & 0,4 & 1888,59 \\
\hline
\end{tabular}

Os resultados apresentados na Tabela 23 são bastante úteis a trabalhos de natureza hidrológica e foram utilizados neste trabalho para a obtenção dos parâmetros $\mathrm{CN}$, área impermeável, área impermeável com armazenamento em depressões, a serem apresentados mais adiante. Segundo Shinma (2015), o parâmetro de áreas impermeáveis é o mais importante na determinação da parcela de escoamento do modelo SWMM e, por isso, sua determinação de maneira correta é fundamental para que a modelagem hidrológica seja coerente.

Sugg et al. (2014), mapeando superfícies impermeáveis em áreas urbanas através de imagens de satélite de alta resolução e AOO, concluíram que o método possui boa acurácia se comparado à tradicional classificação manual utilizada em áreas menores. Desta forma, a AOO permite que se classifique grandes áreas com bons e consistentes resultados. 


\subsection{ADEQUABILIDADE À IMPLANTAÇÃO DE TÉCNICAS COMPENSATÓRIAS}

Os mapas de adequabilidade à implantação de técnicas compensatórias produzidos a partir de álgebra de mapas apresentam as áreas aptas a receberem determinados dispositivos segundo os critérios técnicos apresentados em capítulos anteriores. Estes mapas foram utilizados para a quantificação de dispositivos compensatórios na bacia do Gregório. Utilizando-se a metodologia proposta, podem ser produzidos diferentes tipos de mapas segundo a necessidade de cada área de estudos e das técnicas compensatórias pretendidas. Nesta metodologia, mesmo que se utilize as mesmas camadas, os resultados dos mapas podem ser diferentes dependendo dos valores de critérios adotados como, por exemplo, profundidade de lençol freático, declividade de terreno etc. Assim, apesar da metodologia ser relativamente simples, suas possibilidades de aplicação são muitas e os resultados dependem dos objetivos do operador.

Os mapas de adequabilidade serão apresentados neste capítulo para discussão e se encontram também em mais detalhes no Apêndice $A$.

O resultado da adequabilidade da área de estudos à implantação de pavimentos permeáveis é apresentado na Figura 35. 


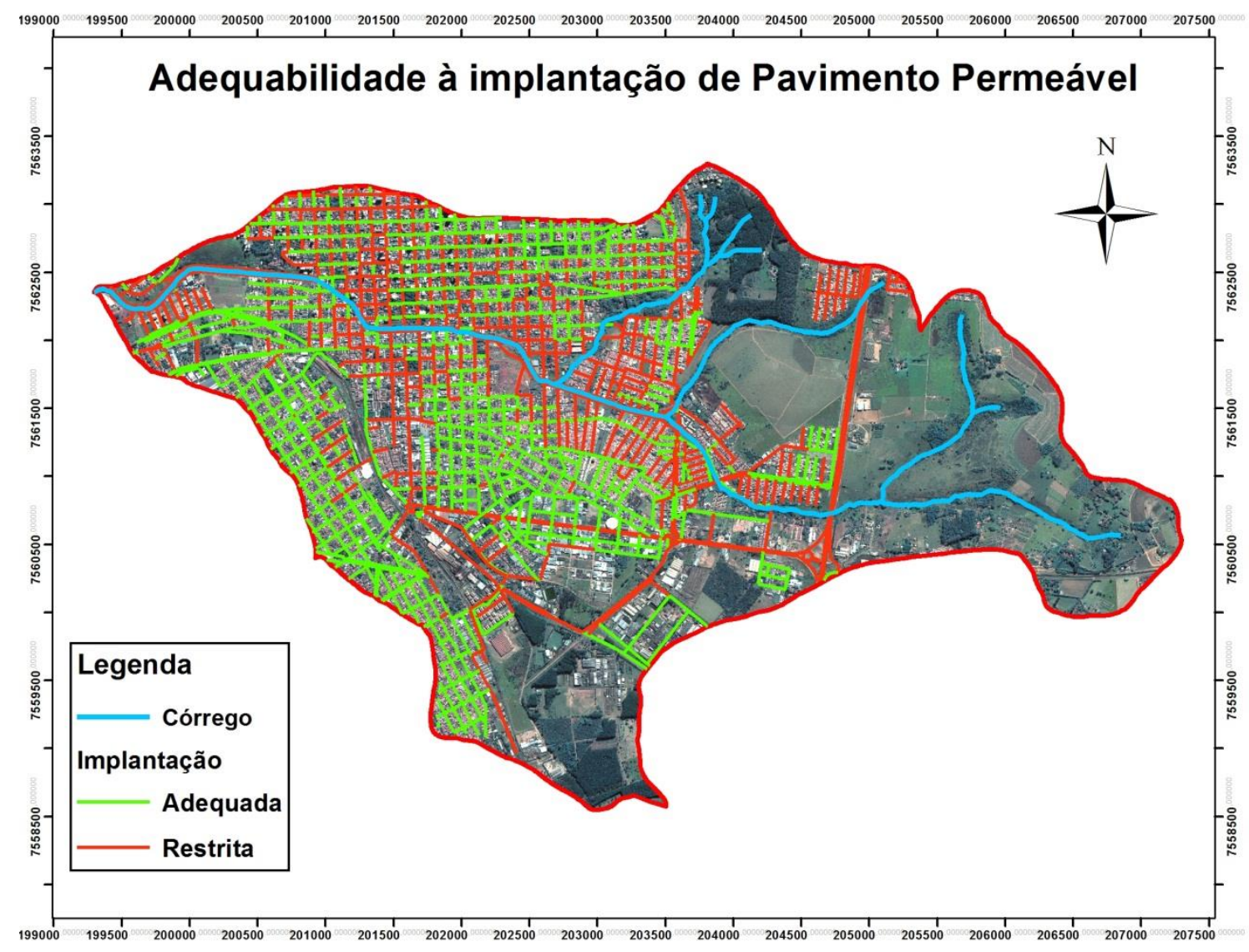

Figura 35 - Adequabilidade da área de estudos à implantação de pavimentos permeáveis

A bacia hidrográfica do córrego do Gregório possui declividades bastante acentuadas e, por isso, existem muitas ruas com alta declividade, algumas maiores que $15 \%$ de declividade e, na maioria dos casos, este foi o critério que restringiu a implantação de pavimentos permeáveis nas ruas da bacia hidrográfica.

Para a adequabilidade da área de estudos quanto à implantação de jardins de chuva lineares, uma vez que se ampliou a faixa de declividade aceitável a até $10 \%$, a área de drenagem linear destacou-se como o mais importante fator na restrição de ruas à implantação do dispositivo. É importante destacar que não foi considerada a qualidade dos passeios públicos e suas dimensões na álgebra que gerou o mapa (Figura 36). Assim, em um eventual planejamento urbano no qual pretende-se implantar os dispositivos, estudos mais aprofundados das condições dos locais considerando, por exemplo, dimensões do passeio, instalações subterrâneas, aporte de sedimentos e desníveis bruscos - devem ser realizados para a decisão dos locais de instalação. Ao todo, as ruas aptas a receberem pavimentos permeáveis representaram $6,81 \%$ da área total da bacia e $64,58 \%$ de todas as ruas da bacia hidrográfica. 


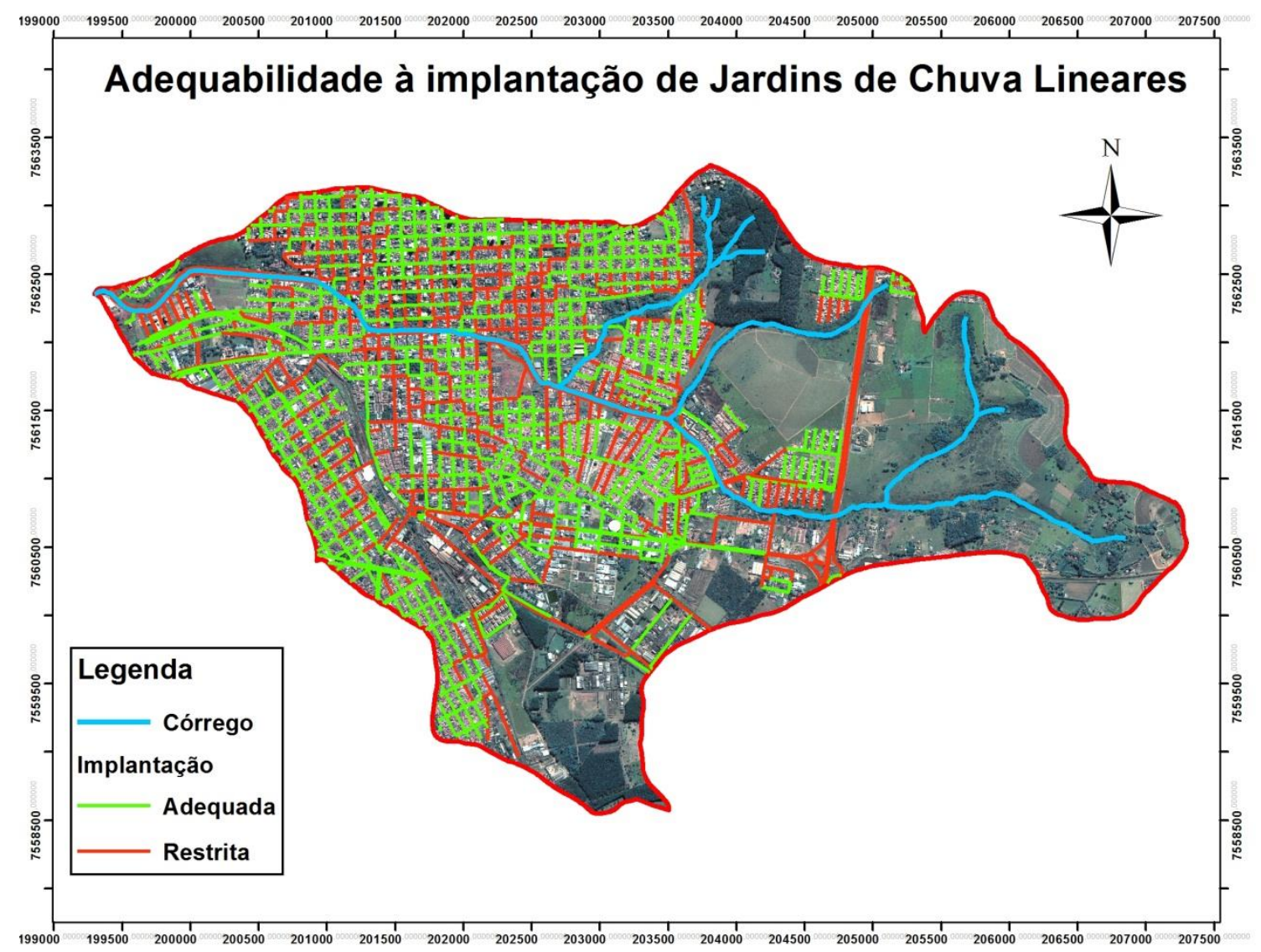

Figura 36 - Adequabilidade da área de estudos à implantação de jardins de chuva lineares

Em relação à adequabilidade à instalação de telhados verdes, fora a óbvia necessidade de serem instalados sobre telhados, o mapa não traz surpresas e tampouco restrições, ou seja, a instalação é permitida em toda a bacia. Entretanto, sabe-se que existem critérios técnicos sobre a qualidade dos telhados onde serão instalados, como declividade e tipo de estrutura (Figura 37). Estes fatores podem ser restritivos e, por isso, a possibilidade de instalação deve ser analisada pelo projetista caso a caso. Ao todo, as áreas destinadas a jardins de chuva, se for considerada a instalação dos mesmos em todas as áreas aptas, foi de 1,33 hectares, o que representa apenas $0,07 \%$ da área total da bacia. 


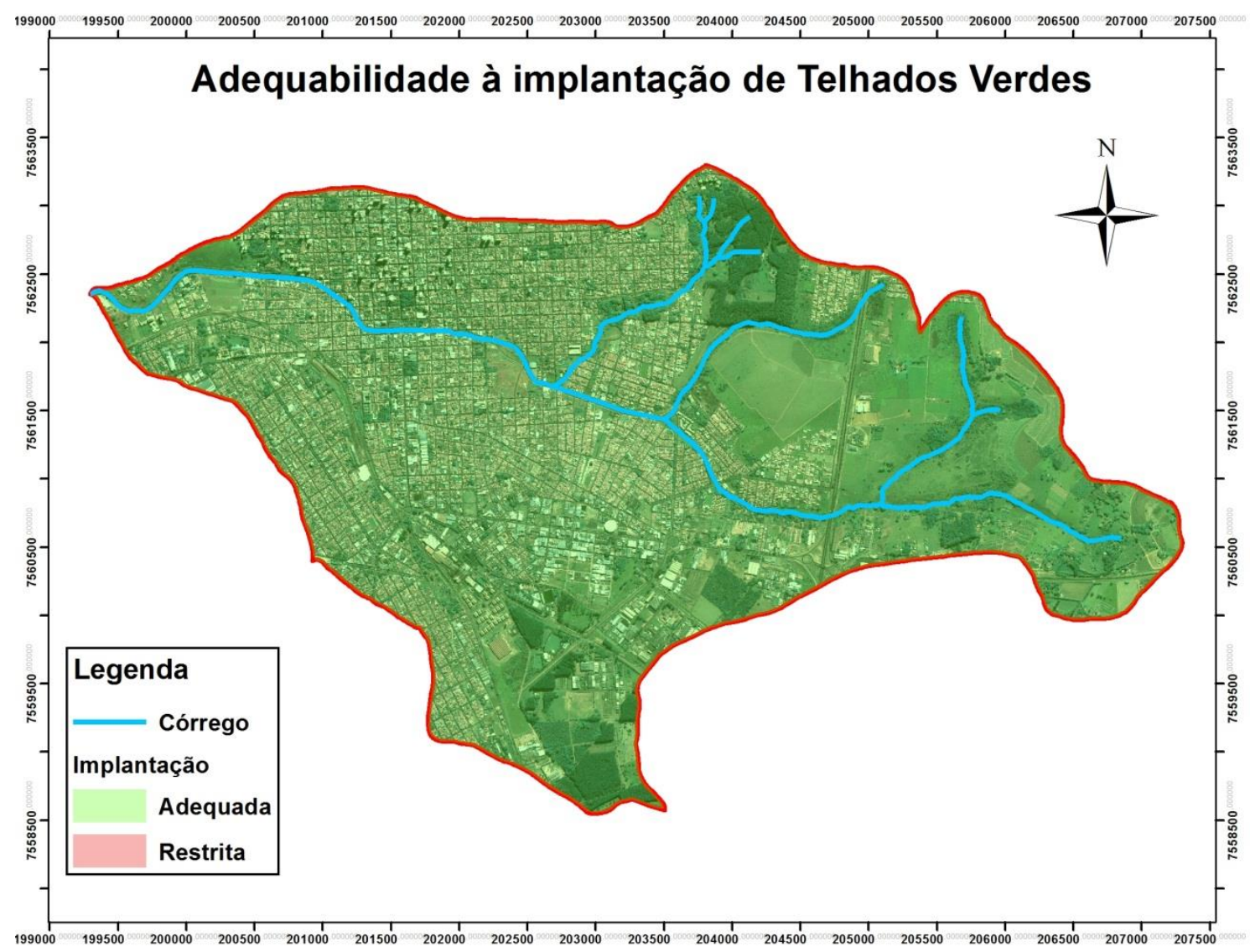

Figura 37 - Adequabilidade da área de estudos à implantação de telhados verdes

O mapa de adequabilidade à implantação de trincheiras lineares é apresentado na Figura 38. Este expõe as ruas da cidade que, frente à uma primeira análise, estão aptas a receber dispositivos de infiltração lineares. Por serem dispositivos de infiltração, as áreas próximas às nascentes dos córregos ficaram impedidas de receber os dispositivos, uma vez que o lençol freático é raso. Neste mapa, uma parte considerável das ruas da bacia hidrográfica foi considerada apta a receber os dispositivos. A maioria das restrições ocorreu por excesso de declividade das ruas, principalmente naquelas ruas perpendiculares ao córrego do Gregório, nas quais a declividade é realmente acentuada. Somado a isso, o fato do solo da bacia ter boa permeabilidade contribui para a adequabilidade da área à implantação de dispositivos de infiltração. 


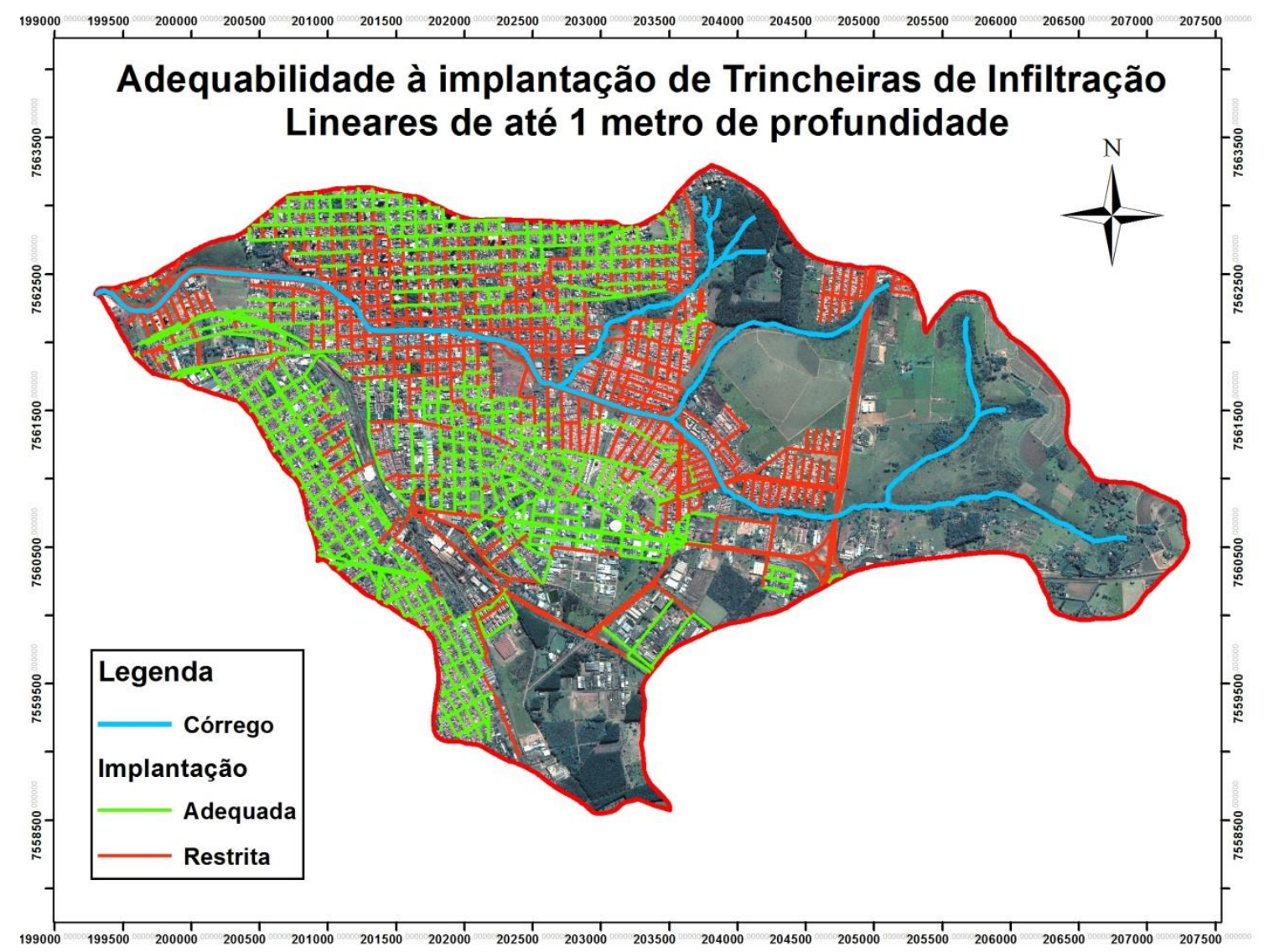

Figura 38 - Adequabilidade da área de estudos à implantação de Trincheiras de Infiltração Lineares

No mapa de trincheiras de infiltração, em números absolutos, dos 1778 trechos de ruas identificados na camada vetorial, $989(55,62 \%)$ trechos poderiam receber trincheiras de infiltração. Em termos de comprimento de rua, as trincheiras ocupariam $50,07 \%$ dos $205,99 \mathrm{~km}$ de ruas da bacia hidrográfica, ou seja, existiriam 103,14km trincheiras dispostas linearmente por toda a bacia hidrográfica.

Na Figura 39 é apresentado o mapa de adequabilidade à implantação de dispositivos de infiltração na fonte, que pode ser utilizado para trincheiras de infiltração ou poços de infiltração instalados em residências, praças ou estacionamentos, por exemplo. 


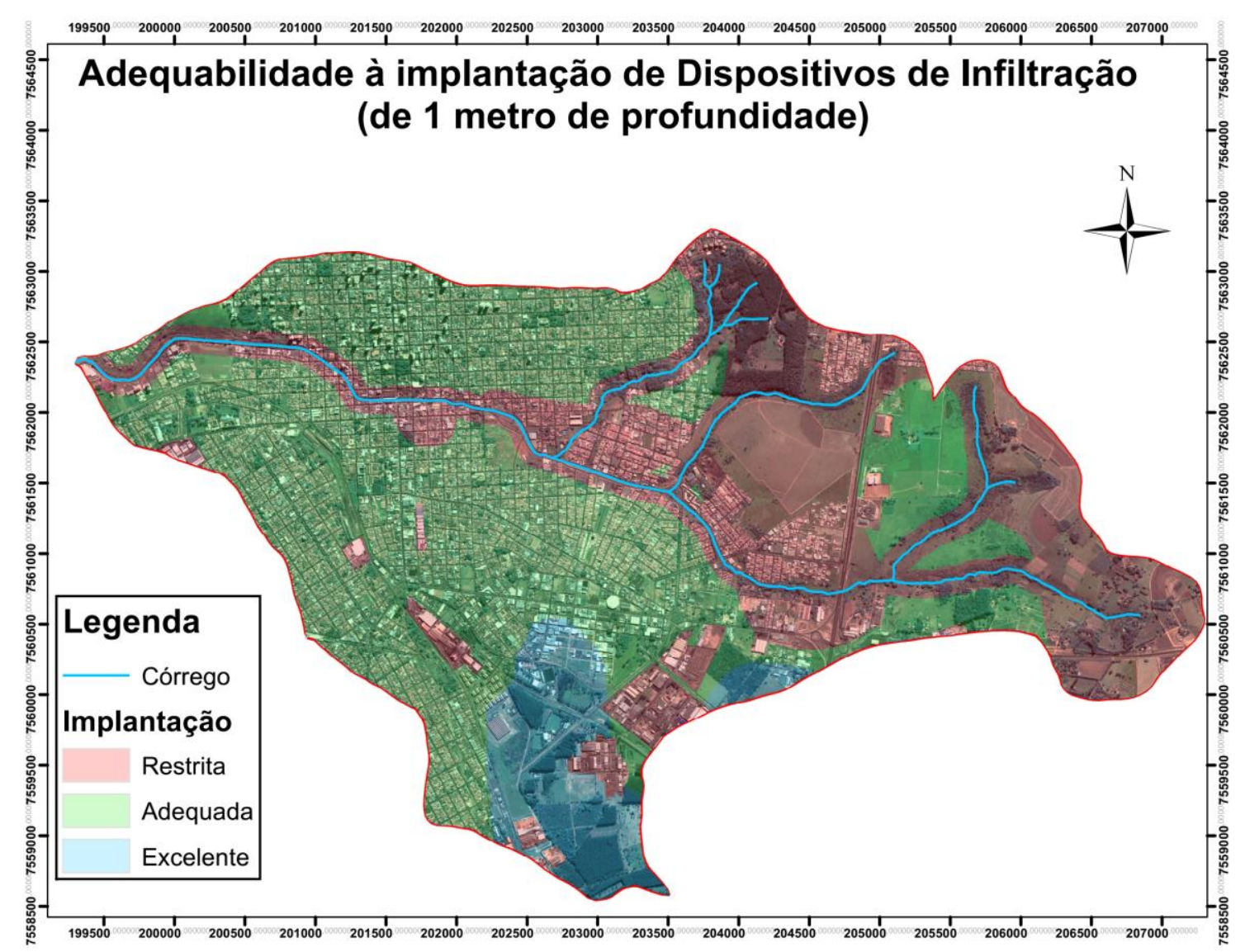

Figura 39 - Adequabilidade da área de estudos à implantação de dispositivos de infiltração na fonte

Para o caso do mapa de adequabilidade à implantação de microreservatórios individuais, pela facilidade de instalação e pela ausência de restrições, toda a área da bacia foi considerada apta à implantação (Figura 40). 


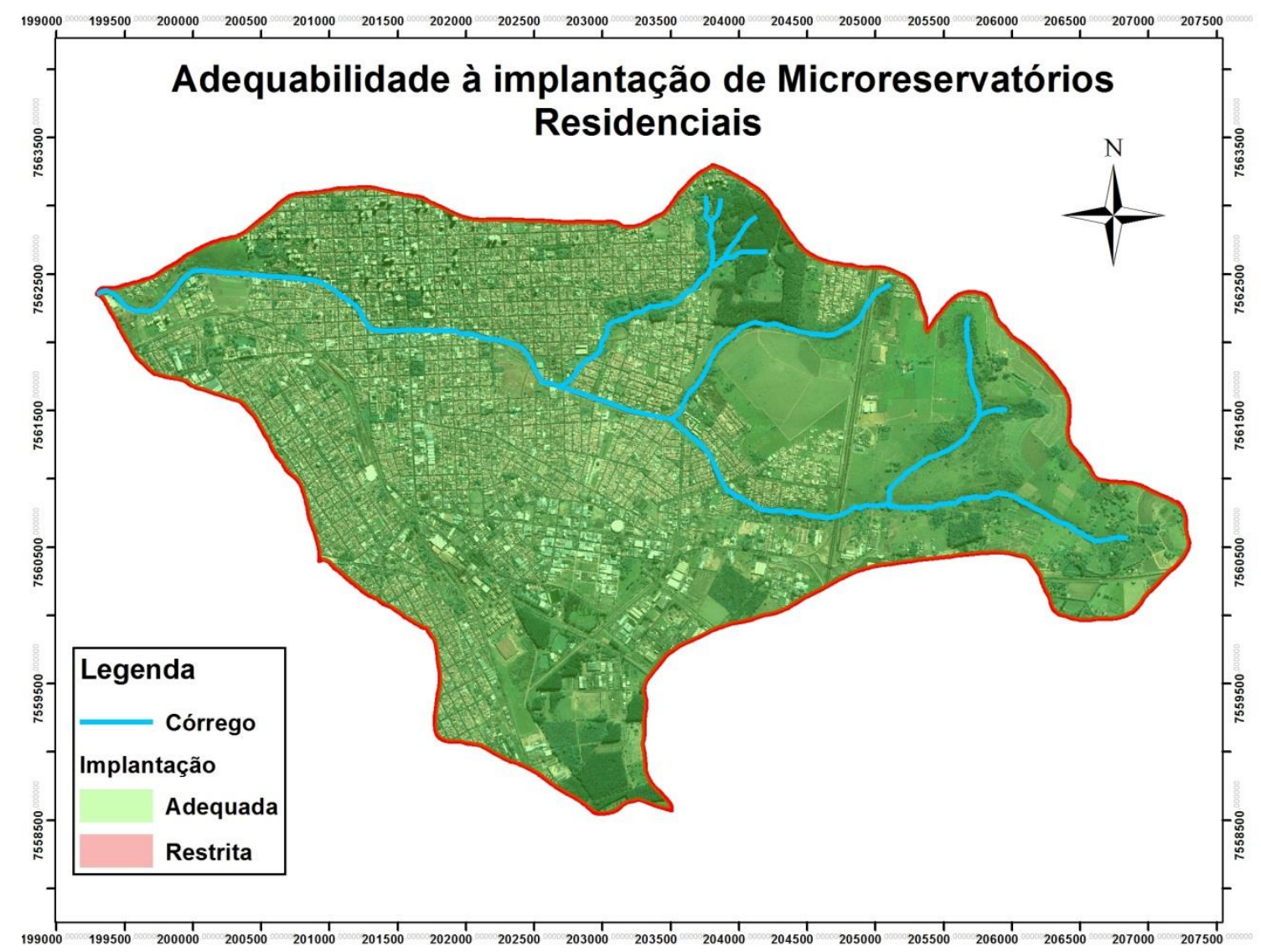

Figura 40 - Adequabilidade da área de estudos à implantação de microreservatórios

De modo geral, a metodologia proposta para a alocação das técnicas compensatórias cumpriu bem seu papel, e os mapas de adequabilidade forneceram um panorama da possibilidade de implantação de dispositivos na bacia hidrográfica do córrego do Gregório. A partir dos mapas foi possível quantificar o número de dispositivos que podem ser instalados na área, fornecendo importantes informações para a montagem dos cenários hipotéticos.

Alguns pesquisadores propuseram outras maneiras de se locar técnicas compensatórias através de sensoriamento remoto, SIG ou ferramentas de otimização. Zhen, Yu e Lin (2004) propuseram uma metodologia para locação de técnicas compensatórias - principalmente bacias de detenção, com ou sem lâmina de água a partir de um processo de otimização. O processo visava principalmente a restrição à instalação de técnicas compensatórias em zonas críticas quanto à produção de poluição difusa e a redução de custos de implantação e manutenção de dispositivos. Um fator limitante do método proposto é a necessidade de pré-seleção de áreas preferenciais sendo, portanto, mais apropriado para áreas em desenvolvimento e com 
relativa disponibilidade de espaço. Até o presente momento, não existem relatos de testes do método em nenhuma área urbana já desenvolvida.

Jensen, Quinn e Davis (2010) propuseram a utilização de imagens MDE provenientes de LIDAR de alta resolução para identificação das linhas de drenagem e identificação de pontos adequados para a instalação de técnicas compensatórias. O método proposto teve por objetivo a identificação de áreas propícias à instalação de telhados verdes e células de bioretenção na fonte. Este foi desenvolvido baseandose em modelos digitais de elevação de alta resolução, nos quais foi identificada a declividade dos telhados na faixa pretendida $(2 \%)$ e analisou-se as linhas preferenciais de drenagem para alocação de estruturas de bioretenção com intuito de se otimizar a redução de escoamento. Eslami, Fazeli e Mehraban (2011) utilizaram lógica Fuzzy para locação de células de bioretenção em um pequeno conjunto residencial de aproximadamente 7 hectares. $O$ método baseou-se no cruzamento de informações de geoespaciais através de mapas de declividade, distância de construções, distância dos pontos da rede de drenagem e distâncias dos pontos de drenagem (bocas de lobo). As áreas dos mapas foram classificadas como pobres, razoáveis e boas. O resultado final interpolou todas as informações para a obtenção de um mapa com escala continua das áreas mais adequadas para a implantação dos dispositivos. Apesar de eficiente, o método limita-se a pequenas áreas como condomínios e loteamentos, uma vez que, por apresentar os resultados em escala continua, o mapa final exige que a escolha dos locais de implantação ocorra manualmente.

\subsection{SIMULAÇÃO HIDROLÓGICA}

Os resultados obtidos por simulação hidrológica são apresentados individualmente para cada um dos cenários. Inicialmente, foram simulados hidrogramas de cheia para eventos de precipitação de 60 e 120 minutos e tempos de retorno de 2, 5, 10, 50 e 100 anos. Nestes, utilizou-se a distribuição por blocos alternados e intervalos de tempo de 2 minutos para precipitações de 60 minutos de duração e blocos de 4 minutos para precipitações de 120 minutos. Devido ao grande volume de hidrogramas gerados, serão apresentados apenas os resultados mais significantes para a análise e discussão dos resultados, e a série completa de 
hidrogramas pode ser vista no APENDICE B. Alguns dos hietogramas utilizados na geração dos resultados podem ser vistos na Figura 41.

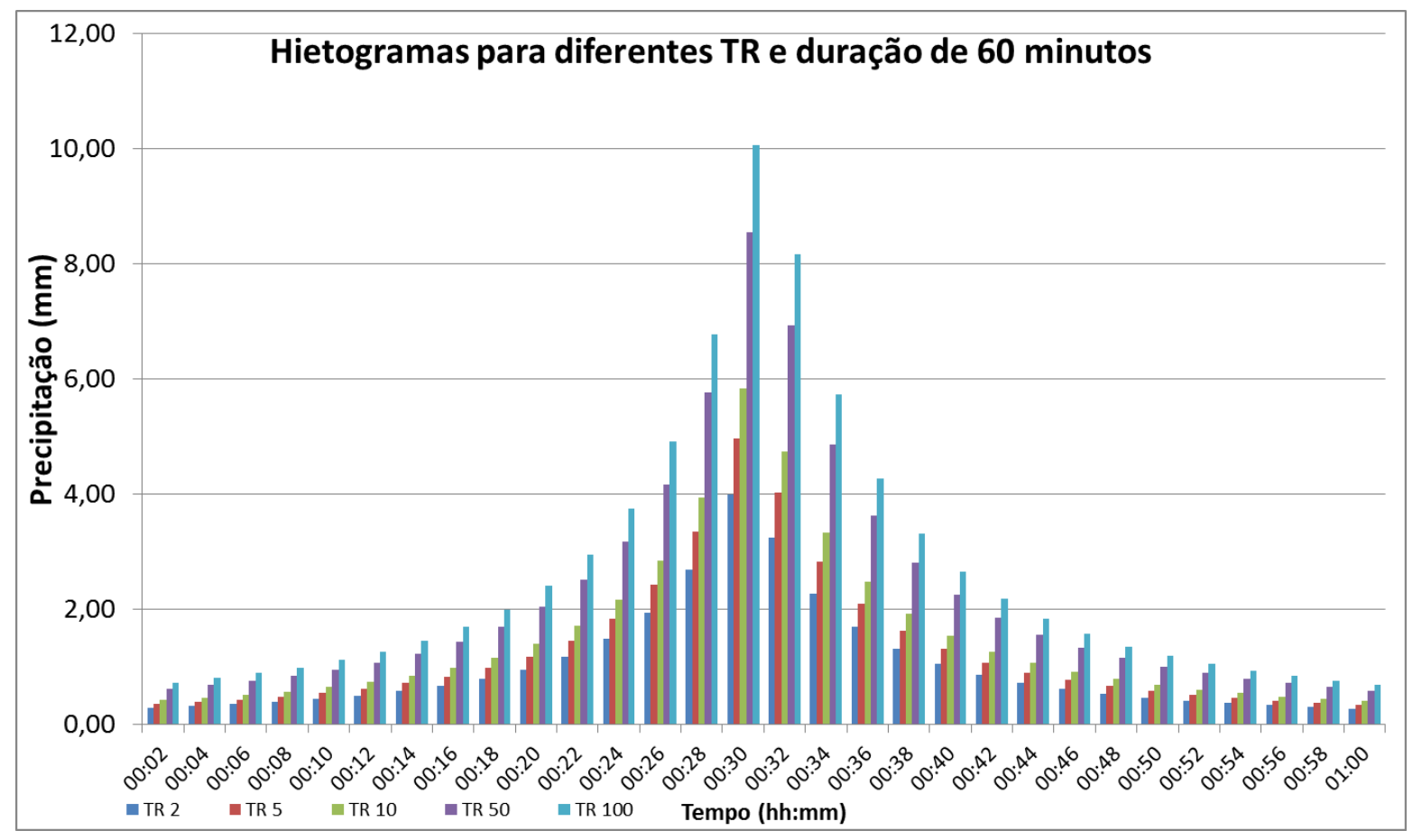

Figura 41 - Hietogramas pelo método dos Blocos Alternados com duração de 60 minutos e diferentes Tempos de Retorno

Sabe-se que o método de distribuição temporal dos blocos alternados tende a maximizar o pico dos hidrogramas das bacias em simulações hidrológicas. Além disso, quanto menores os intervalos de tempo dos blocos, mais extremos tendem a ser os blocos centrais do ietograma. Entretanto, a escolha dos intervalos dos blocos neste trabalho teve de respeitar os incrementos temporais utilizados pelo SWMM para fazer a simulação hidrológica. Estes incrementos temporais, apesar de determinados pelo operador, causam grandes diferenças nos resultados dos hidrogramas, devendo variar de acordo com o tamanho da bacia para se otimizar os resultados e o tempo de simulação hidrológica. Assim, uma vez que a bacia do Gregório é relativamente pequena, o incremento de tempo de cada passo da simulação teve de ser pequeno, neste caso sendo de 1 minuto e 30 segundos, o que exigiu blocos com intervalos curtos nos hietogramas. Os hietogramas para duração de precipitação de 120 minutos são apresentados na Figura 42, onde pode ser observada a tormenta de projeto citada nos capítulos anteriores. 
Avaliação do potencial de aplicação de técnicas compensatórias em áreas urbanas consolidadas

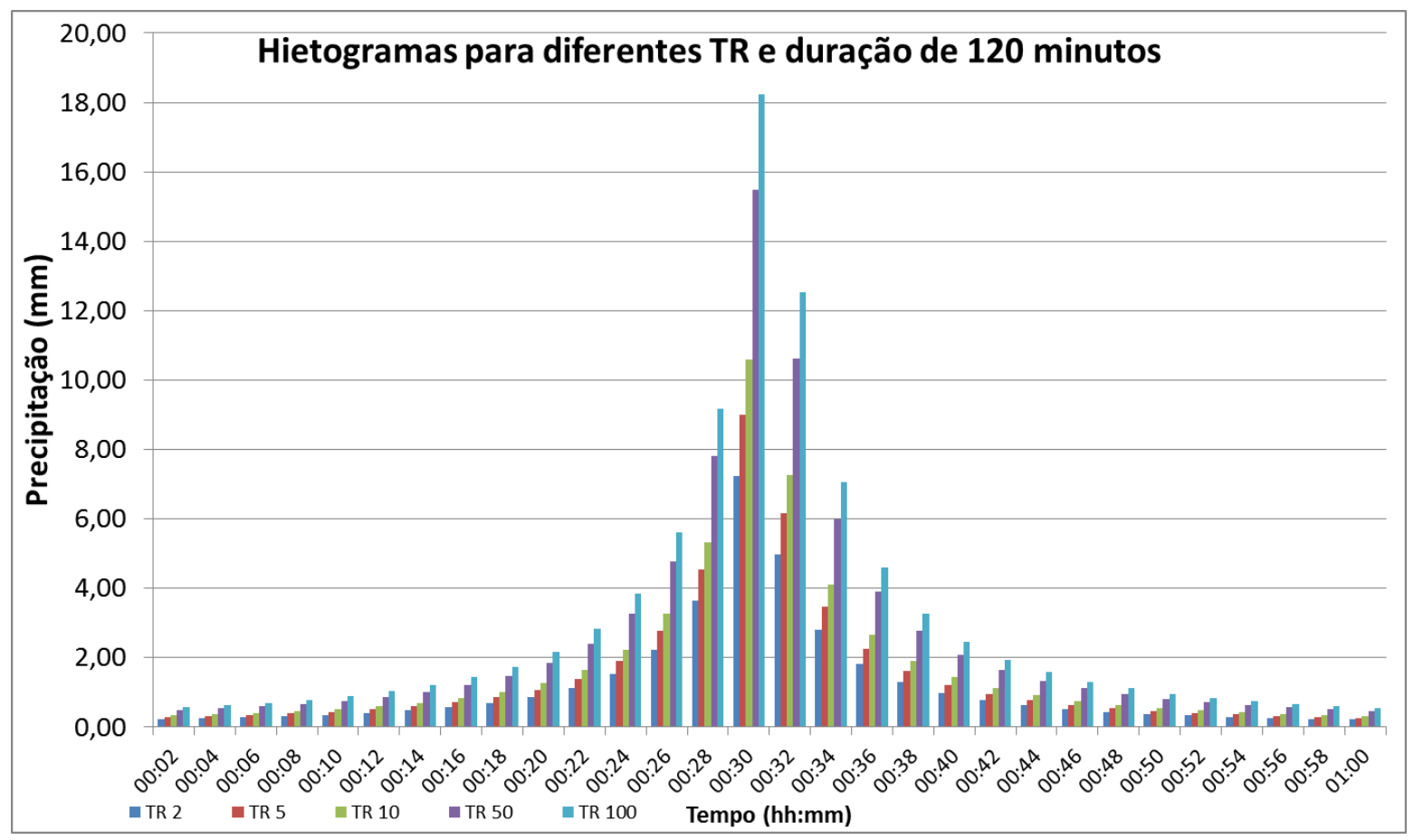

Figura 42 - Hietogramas pelo método dos Blocos Alternados com duração de 120 minutos e diferentes Tempos de Retorno

\subsubsection{Bacia hidrográfica do córrego do Gregório}

A Bacia Hidrográfica do Córrego do Gregório foi representava na simulação segundo se encontrava na data de realização deste trabalho e sem a adição de nenhuma técnica compensatória. A bacia foi representada por 13 sub-bacias, um pluviógrafo e um conjunto de 21 nós e 24 canais que conduziram o escoamento até seu exutório. O projeto final da bacia do Gregório foi formulado após uma série de ajustes e constatações feitas durante a fase de simulação. Tanto os ajustes realizados quanto os resultados obtidos são apresentados neste subcapítulo.

Inicialmente, alguns ajustes tiveram de ser feitos na rede de macrodrenagem do cenário real. Durante uma simulação, o SWMM é capaz de identificar pontos de inundação baseando-se na capacidade de vazão dos canais calculada pela equação de Manning e, nos casos de transbordamento, o modelo desconta o volume extravasado do fluxo. Entretanto, neste caso de transbordamento de canal a água extravasada não é reintroduzida no sistema pelo software e este ponto torna-se um sumidouro, aumentando consideravelmente o erro da simulação pelo sumiço dos volumes transbordados. Assim, sempre que existirem inundações em canais, deve-se ajustar a rede de macrodrenagem para se solucionar o problema. 
A maneira como se soluciona o problema é através da substituição do nó onde ocorre a inundação por um nó do tipo "divisor de fluxo". O divisor de fluxo cumpre função conforme o nome que recebe, ou seja, divide o fluxo entre dois ou mais canais. A vantagem é a possibilidade de escolha de como deve ocorrer a divisão, sendo uma das opções a divisão por transbordamento. Assim, este divisor permite que se crie canais paralelos com mesma origem e destino do canal original, mas ordenando os canais como principal - onde ocorre o fluxo natural - e secundário - onde só ocorre fluxo quando houver o transbordamento do principal - solucionando o problema no qual a água transbordada era perdida do sistema.

Ao longo da simulação, três pontos de transbordamento foram identificados e foram substituídos por divisores de fluxo que redirecionavam a água proveniente do transbordamento para canais com características semelhantes a sarjetas e superfícies de ruas para que fosse conduzida ao próximo nó da rede de drenagem. Os nós que apresentaram transbordamento localizam-se um em frente ao mercado municipal região de frequentes inundações na cidade -, um ponto no encontro entre o córrego do Gregório e o córrego Sorregotti - popularmente chamado "rotatória da educativa", em referência a um colégio localizado às margens dos córregos - e um ponto próximo à nascente de um córrego totalmente canalizado na região sul da bacia, chamado córrego Simeão. Todos os três pontos encontrados na simulação sofrem com casos de alagamentos e inundações, com relatos na mídia local, conforme ANEXO 1 (SÃO CARLOS AGORA, 2016). Dentre os três pontos, o que encontra em frente ao mercado municipal é, sem dúvidas, o mais crítico da bacia.

Outro problema constatado foi a necessidade de se dividir a sub-bacia $10 \mathrm{em}$ duas sub-bacias menores, surgido a partir da maneira como o modelo realiza a transição entre sua etapa hidrológica e sua etapa hidráulica. Cada sub-bacia tem como exutório um ponto único da rede de drenagem e seu hidrograma é calculado a partir de informações das sub-bacias e da precipitação. Em seguida, as vazões do hidrograma são transferidas para a etapa hidráulica do modelo. Durante essa transição, o software "atrasa" suavemente o hidrograma de acordo com as informações de largura de escoamento e rugosidade da bacia. Este atraso visa reproduzir o tempo de percurso da água sobre a superfície da bacia e posterior propagação do hidrograma ao longo da rede. Entretanto, para bacias grandes representadas como uma única bacia, como no caso da sub-bacia 10 , toda a sua área 
teria como exutório apenas um nó o que, além de ignorar todo o trecho existente da rede de macrodrenagem, representaria um tempo de concentração extremamente curto para a magnitude da bacia e, nestes casos, o escoamento produzido nas cabeceiras das sub-bacias chegaria ao exutório ao mesmo tempo que o escoamento produzido nas áreas próximas ao exutório, distorcendo o hidrograma e amplificando seu pico. Desta forma, a divisão da bacia 10 nas sub-bacias 10.1 e 10.2 permitiu uma melhor representação da propagação do hidrograma da rede de drenagem. Krebs et al. (2014) abordam este problema e reafirmam que a adoção de sub-bacias muito grandes leva o modelo SWMM a superestimar a vazão de pico devido à resposta muito rápida da bacia à precipitação incidente.

Os hidrogramas da bacia hidrográfica do Gregório para os diferentes eventos de precipitação encontram-se na Figura 43.

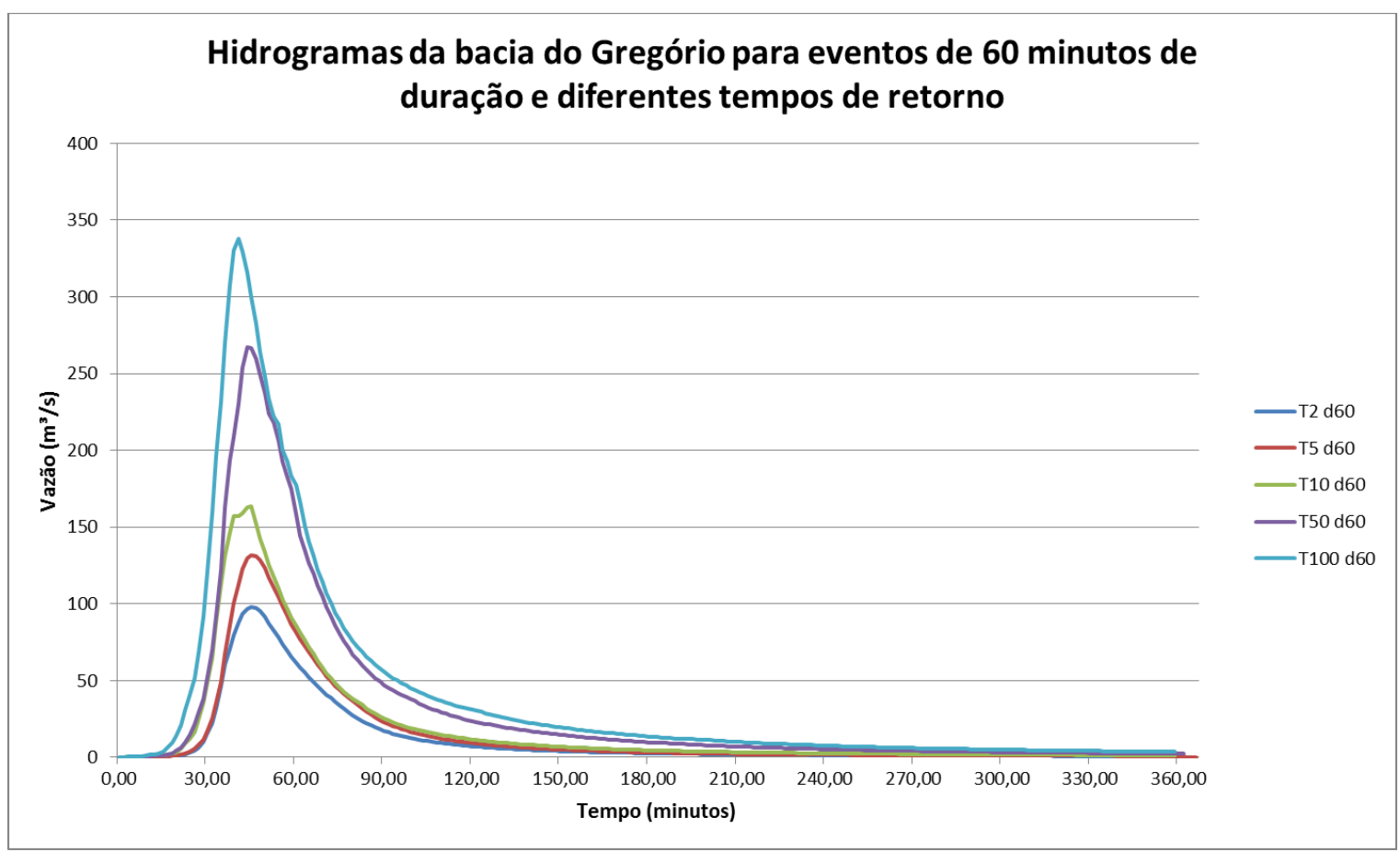

Figura 43 - Hidrogramas para a bacia hidrográfica do córrego do Gregório

No resultado da simulação com precipitação de 60 minutos e diferentes tempos de retorno, nota-se um grande aumento dos valores de vazão de pico à medida que aumenta a precipitação, saindo de aproximadamente $98 \mathrm{~m}^{3} / \mathrm{s}$ para tempo de retorno 2 para cerca de $338 \mathrm{~m}^{3} / \mathrm{s}$ com tempo de retorno de 100 anos, um aumento de $244,8 \%$. Quanto ao tempo de pico, apesar de se notar uma leve variação, para todos os hidrogramas este ficou em torno de 45 minutos, cerca de 15 minutos após o pico de 
intensidade de precipitação. Um ponto a ser destacado é o pico do hidrograma de TR 10 anos, que possui um ponto de inflexão. Este ponto é causado pela superação da capacidade de vazão do trecho canalizado após a região do mercado municipal. Sendo o trecho de contorno fechado, o hidrograma sofre esta variação brusca no instante de seu pico pela queda na capacidade de vazão dos trechos assim que é atingida a sessão plena. $O$ modelo propaga essa variação até o exutório da bacia. Para as precipitações de 120 minutos de duração, os hidrogramas são apresentados na Figura 44.

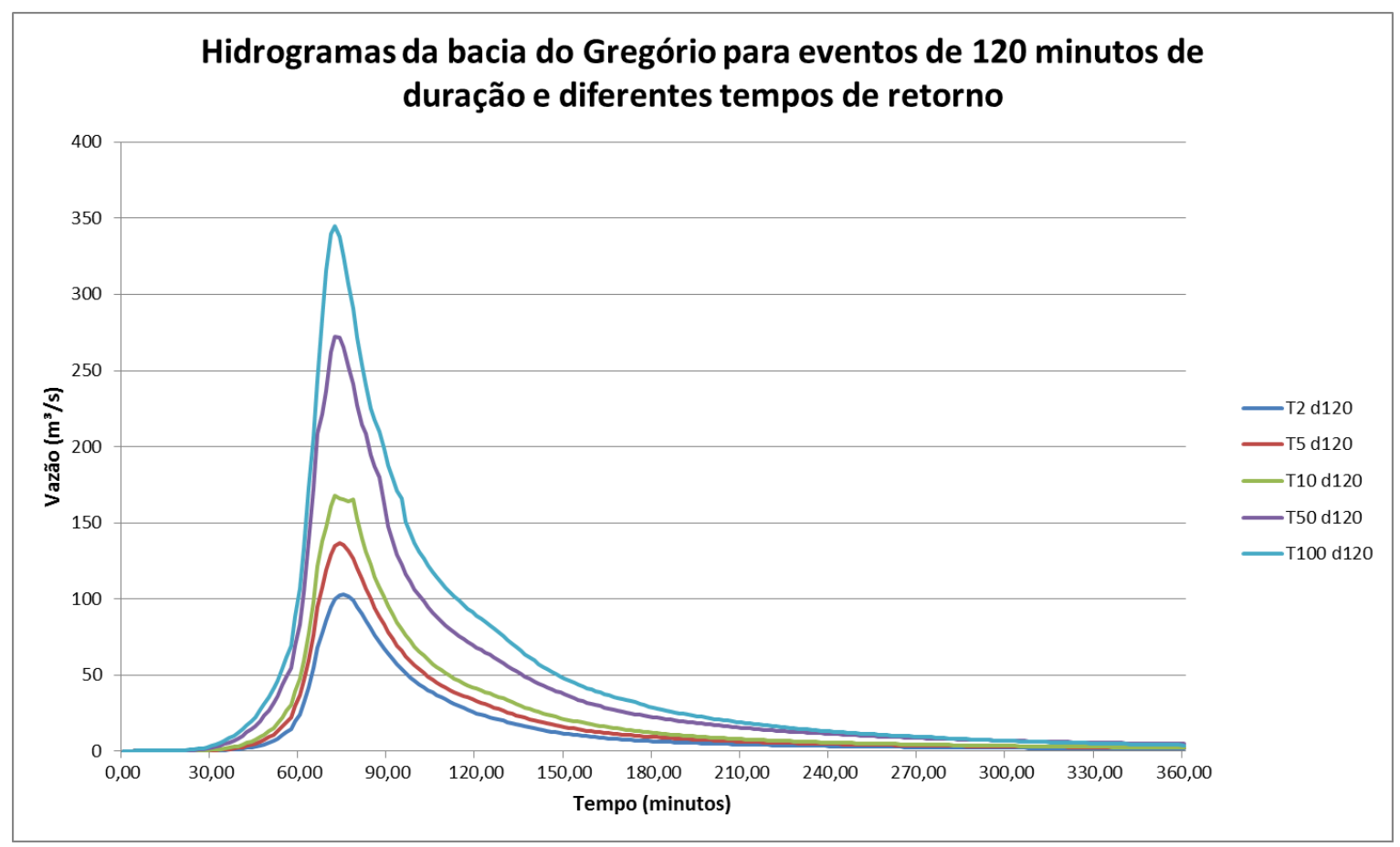

Figura 44 - Hidrogramas para a bacia hidrográfica do córrego do Gregório

Nos hidrogramas para precipitações de 120 minutos, o aumento da vazão de pico na comparação entre tempo de retorno de 2 e 100 anos foi de $234,57 \%$. O pico da maioria dos hidrogramas ocorreu em torno de 72 minutos, 12 minutos após o bloco de maior intensidade de chuva. Novamente o ponto de inflexão foi detectado para o hidrograma de 10 anos. Entre os dois gráficos apresentados, não houveram grandes diferenças de vazões de pico entre tempos de retorno semelhantes, havendo diferenças significativas apenas no instante em que ocorre o pico. Isto ocorre pelo fato de que precipitações sintéticas - especificamente para o método dos blocos alternados - com mesmo tempo de retorno, mas com durações diferentes, não tem grandes diferenças nos volumes dos blocos principais possuindo, portanto, picos 
semelhantes, embora o volume total precipitado seja diferente (vide Figura 28). Para o ponto mais crítico da bacia, no encontro dos córregos do Simeão e do Gregório em frente ao mercado municipal, foram gerados alguns hidrogramas para se analisar vazões e o comportamento da rede de macrodrenagem (Figura 45).

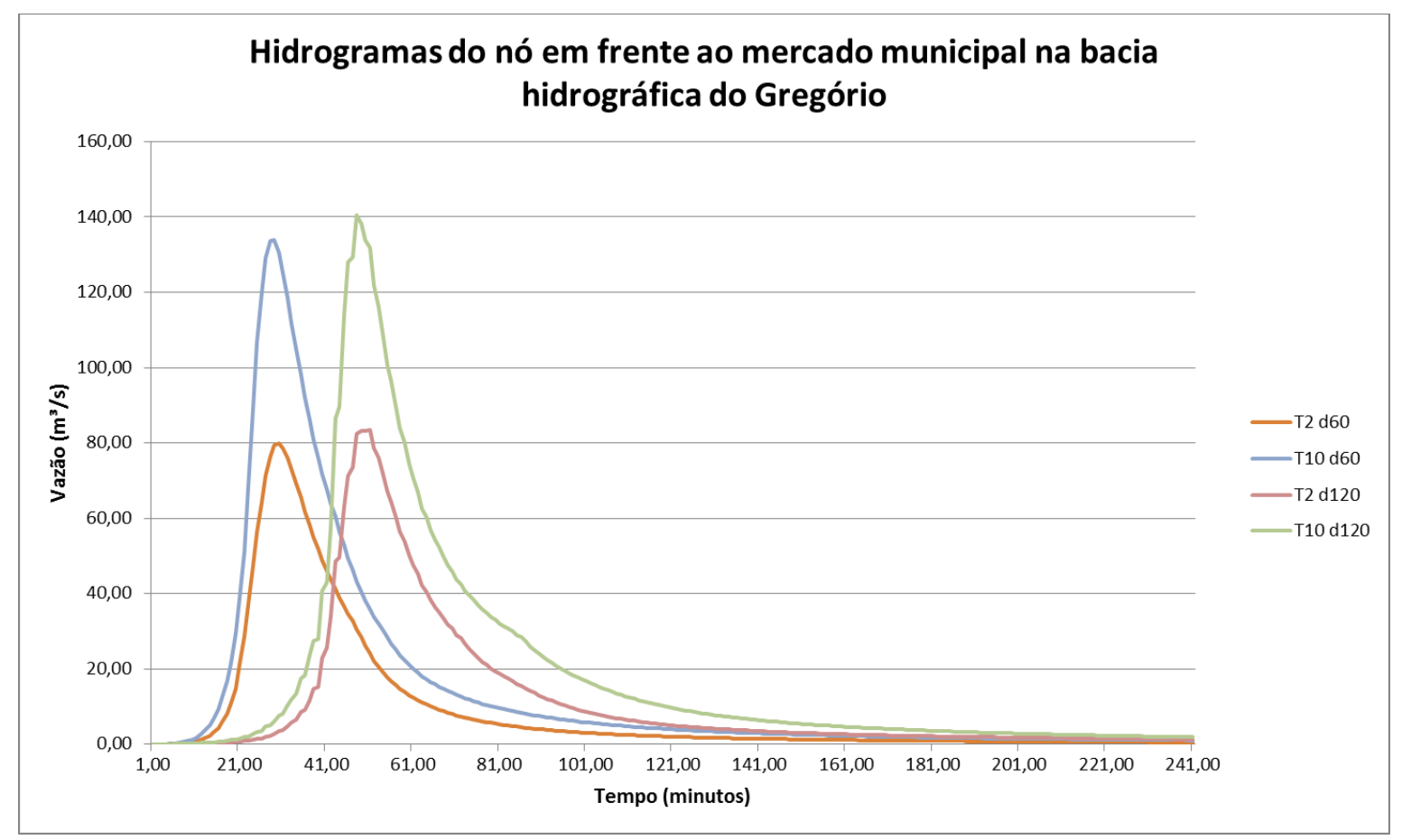

Figura 45 - Hidrogramas para a bacia hidrográfica do córrego do Gregório

Nos hidrogramas apresentados, novamente não se nota grandes diferenças na magnitude do pico, apenas no instante em que este ocorre. Assim, considera-se desnecessária a investigação dos hidrogramas gerados pelas precipitações de durações diferentes e, portanto, serão avaliados em maioria os hidrogramas para precipitações de 120 minutos de duração.

Com relação ao ponto de inflexão, no trecho analisado pouco antes do mercado municipal, a capacidade da galeria é de pouco mais que $162 \mathrm{~m}^{3} / \mathrm{s}$ (equação de Manning) e, em seção plena, cai para cerca de $135 \mathrm{~m}^{3} / \mathrm{s}$, uma vez que, segundo Shinma (2015), a galeria possui formato retangular com aproximadamente $3,5 \mathrm{~m}$ de profundidade e $6 \mathrm{~m}$ de largura, declividade de cerca de $0,0056 \mathrm{~m} / \mathrm{m}$ e suposta rugosidade de 0,013 - rugosidade dificilmente mantida dado à data de construção da galeria, por volta de 1974. Assim, embora não tenham ocorrido nas simulações (até pela adoção da propagação de hidrogramas pelo método da onda cinemática, que desconsidera efeitos de remanso), é bastante provável que ocorram inundações com 
precipitações de tempo de retorno muito menores que 10 anos na galeria. Vale ressaltar aqui que os registros fotográficos encontrados (Figura 46), datados de 1974, diferem muito dos formatos utilizados na simulação e que, se mantida a geometria conforme registrada na imagem (trapezoidal fechado com mudança para trecho de geometria composta, aparentemente entre retangular e capacete), a capacidade de vazão do trecho canalizado do Gregório em frente ao mercado municipal pode ser muito inferior ao valor apresentado, principalmente pela alta rugosidade, pelas colunas junto às paredes do canal e outros obstáculos visíveis na imagem.

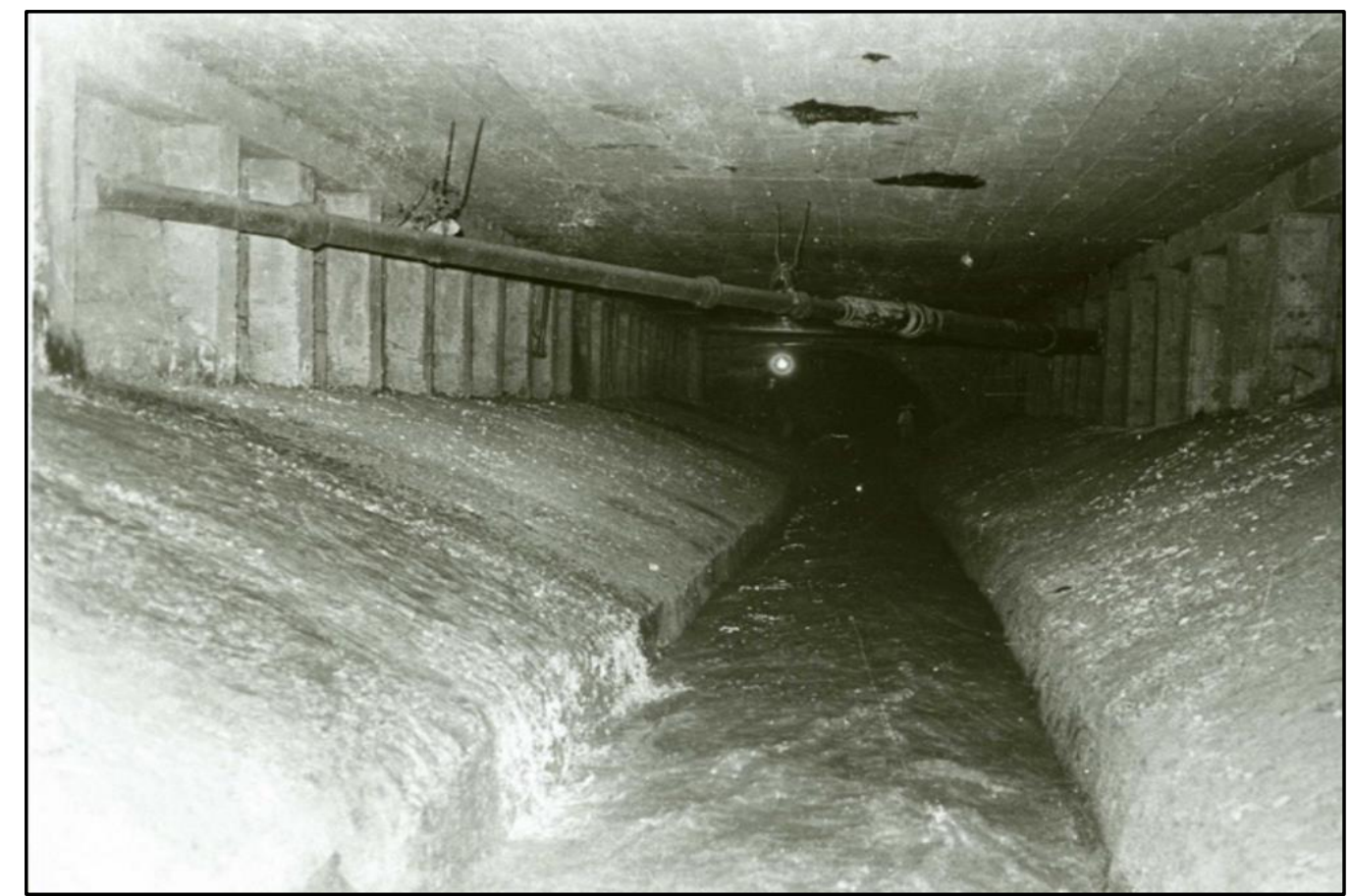

Figura 46 - Registro fotográfico datado de 1974 de trecho canalizado (próximo ao mercado municipal, local exato desconhecido) do córrego do Gregório (Fonte: https://aguasdamemoria.wordpress.com)

Ademais, apresenta-se na Tabela 24, para facilitar comparações com outros cenários a serem analisados, os valores de vazão de pico dos hidrogramas apresentados nas figuras Figura 44 e Figura 45. 
Tabela 24 - Valores de vazão de pico $\left(\mathrm{m}^{3} / \mathrm{s}\right)$ para o exutório da bacia e para o ponto em frente ao mercado municipal para precipitações de 120 minutos no cenário real

\begin{tabular}{cccccc} 
Tempo de retorno & $\mathbf{2}$ & $\mathbf{5}$ & $\mathbf{1 0}$ & $\mathbf{5 0}$ & $\mathbf{1 0 0}$ \\
\hline Exutório & 103,13 & 136,39 & 168,13 & 272,39 & 345,05 \\
Mercado & 83,47 & 111,62 & 140,51 & 231,00 & 287,11 \\
\hline
\end{tabular}

Quanto aos valores de extravasamento da seção em frente ao mercado municipal, são levantados a seguir alguns relatos encontrados na literatura. Barros (2005), em um trabalho de previsão de enchentes para a bacia hidrográfica do Gregório, previu a ocorrência de extravasamento da seção em frente ao mercado municipal, exatamente no encontro entre os córregos do Gregório e Simeão, quando a vazão atingisse $111,98 \mathrm{~m}^{3} / \mathrm{s}$, valores inferiores ao calculado pelo SWMM no presente trabalho. Mais além, durante estudos que subsidiaram o PDDUAS da área de estudos, foi concluído pelos técnicos que a galeria não teria condições de veicular vazões superiores a 50m³/s (SHS - Consultoria e Projetos de Engenharia LTDA., 1993 e 1999). Barros (2005), após consulta pessoal a profissionais de São Carlos, justificou o valor reduzido apresentado no relatório prévio do PDDUAS afirmando que a união dos dois córregos citados, somados ainda a uma galeria de águas pluviais mal posicionada no local, tornavam o fluxo muito turbulento, o que prejudicava o fluxo do córrego principal.

Posteriormente, obras na junção do córrego do Gregório com o córrego Simeão foram realizadas para rebaixamento de 0,60 metros do fundo da galeria e readequações nas entradas de água de galerias pluviais e córrego Simeão, conforme pode ser visto no ANEXO B (SÂO CARLOS AGORA, 2010). Desde a realização destras obras, não foram encontrados trabalhos que descrevessem ou avaliassem a capacidade de vazão do trecho. No trecho rebaixado, a galeria passou a ter as dimensões adotadas no presente trabalho. Na simulação do cenário real, a galeria em frente ao mercado municipal (presumindo-se rugosidade de 0,013) apresentou máxima de vazão $150,28 \mathrm{~m}^{3} / \mathrm{s}$ e vazão máxima em seção plena de $129,80 \mathrm{~m}^{3} / \mathrm{s}$.

\subsubsection{Bacias de detenção}

A simulação hidrológica do cenário de bacias de detenção foi composta pelo cenário real acrescido dos 5 reservatórios previstos no PDDUAS. Os resultados são apresentados nas Tabelas 25 e 26. 
Tabela 25 - Comparação entre hidrogramas do cenário bacias de detenção em relação ao cenário real para o exutório da bacia

\begin{tabular}{ccccc}
$\begin{array}{c}\text { Tempo de } \\
\text { retorno }\end{array}$ & $\begin{array}{c}\text { Redução } \\
\text { vazão de } \\
\text { pico (\%) }\end{array}$ & $\begin{array}{c}\text { Redução } \\
\text { tempo de } \\
\text { pico (\%) }\end{array}$ & $\begin{array}{c}\text { Redução } \\
\text { volume (\%) }\end{array}$ & $\begin{array}{c}\text { Redução de } \\
\text { volume }\left(\mathbf{m}^{\mathbf{3}}\right)\end{array}$ \\
\hline $\mathbf{2}$ & 6,01 & 2,00 & $-0,66$ & -2.000 \\
$\mathbf{5}$ & 5,94 & 2,04 & $-0,98$ & -2.000 \\
$\mathbf{1 0}$ & 5,11 & 0,00 & $-1,19$ & -7.000 \\
$\mathbf{5 0}$ & 6,42 & 0,00 & 1,30 & 11.000 \\
\hline $\mathbf{1 0 0}$ & 6,90 & 2,08 & 3,03 & 40.000 \\
\hline
\end{tabular}

Tabela 26 - Valores de vazão de pico $\left(\mathrm{m}^{3} / \mathrm{s}\right)$ para o exutório da bacia e para o a região do mercado para precipitações de 120 minutos de duração no cenário de bacias de detenção

\begin{tabular}{cccccc}
\hline Tempo de retorno & $\mathbf{2}$ & $\mathbf{5}$ & $\mathbf{1 0}$ & $\mathbf{5 0}$ & $\mathbf{1 0 0}$ \\
\hline Exutório & 97,50 & 128,29 & 159,54 & 254,90 & 322,04 \\
Mercado & 77,05 & 104,03 & 128,87 & 209,45 & 264,89 \\
\hline
\end{tabular}

Houve uma redução na vazão de pico para todas as precipitações analisadas e os valores percentuais de redução se mantiveram praticamente constantes para todos os eventos. Curiosamente, as bacias de detenção obtiveram melhores resultados de redução de vazão de pico para os maiores eventos. Dalmodaram et al. (2010) afirmam que bacias de detenção, por serem geralmente dimensionadas para tempos de retorno iguais ou superiores a 100 anos, costumam não surtir grandes efeitos na redução de vazões de pico de eventos menores. Além disso, Emerson, Welty e Traver (2006) afirmam que estes dispositivos de detenção de grande porte podem ser prejudiciais ao sistema de drenagem durante eventos de grande frequência anual pois, além de serem pouco eficientes nestes casos, ainda prolongam demasiadamente as altas vazões, elevando o risco de erosão nos canais.

Quanto ao tempo de pico dos hidrogramas, não foram detectadas mudanças significativas nos valores analisados, nem mesmo para os maiores eventos. Um fato interessante de registro é a diferença de volumes entre hidrogramas do cenário real e do cenário de bacias de detenção. Em teoria, pelo fato de reservatórios de detenção não promoverem a infiltração de água no solo, apenas a detenção temporária de um volume de água, os volumes de hidrogramas com bacias de detenção e sem bacias de detenção deveriam ser semelhantes (principalmente se desprezada a parcela de evaporação, como ocorreu neste trabalho). Entretanto, na simulação realizada, o uso de bacias de detenção prolongou muito a duração dos hidrogramas de cheia das 
bacias, alguns a durações superiores a 20 horas. Assim, se analisados em tempos menores do que a duração total dos hidrogramas como, por exemplo, as 6 horas aqui analisadas, a comparação de volumes leva a erros devido ao deslocamento do centro de massa de hidrogramas do cenário com bacias de detenção.

Para a área do mercado municipal, as reduções de vazão de pico foram percentualmente superiores aos valores registrados no exutório, conforme apresentado na Tabela 27.

Tabela 27 - Comparação de valores de referência entre hidrogramas do cenário de bacias
\begin{tabular}{|cccc} 
detenção e cenário real para a região do mercado municipal \\
\hline $\begin{array}{c}\text { Tempo de } \\
\text { retorno }\end{array}$ & $\begin{array}{c}\text { Redução vazão de } \\
\text { pico }(\%)\end{array}$ & $\begin{array}{c}\text { Redução } \\
\text { volume }(\%)\end{array}$ & $\begin{array}{c}\text { Redução de } \\
\text { volume }\left(\mathbf{m}^{3}\right)\end{array}$ \\
\hline $\mathbf{2}$ & 7,69 & $-0,82$ & -2.000 \\
$\mathbf{1 0}$ & 8,28 & $-1,97$ & -7.000 \\
$\mathbf{5 0}$ & 9,33 & 1,30 & 9.000 \\
\hline
\end{tabular}

Apesar dos resultados positivos, por se tratarem de cinco bacias de detenção em uma única bacia hidrográfica urbana, os valores de redução de vazão de pico inferiores a $10 \%$ podem ser considerados baixos, ainda mais se os dispositivos forem instalados isoladamente ou sem um planejamento mais amplo de regulação de uso do solo, principalmente por terem como áreas de drenagem regiões predominantemente rurais. Neste contexto, novamente destaca-se que os reservatórios se localizam na região menos desenvolvida da bacia hidrográfica provavelmente pela maior disponibilidade de espaço - e que, em relação ao volume afluente, funcionam de maneira eficiente no controle do escoamento superficial. Entretanto, como controlam o escoamento gerado apenas nas áreas menos desenvolvidas e mais permeáveis, o escoamento gerado nas regiões mais urbanizadas não passa pelos dispositivos, o que limita o potencial dos reservatórios de amortecer hidrogramas em nível de bacia hidrográfica e, consequentemente, diminui seu potencial de combate a inundações.

Uma vez que as bacias de detenção se mostraram relativamente eficientes no controle do escoamento superficial na bacia do Gregório, torna-se interessante uma análise mais aprofundada do funcionamento das bacias individualmente. Assim, apresenta-se na Figura 47 os hidrogramas de entrada e saída para cada uma das cinco bacias de detenção para tempos de retorno de 10 e 50 anos. 


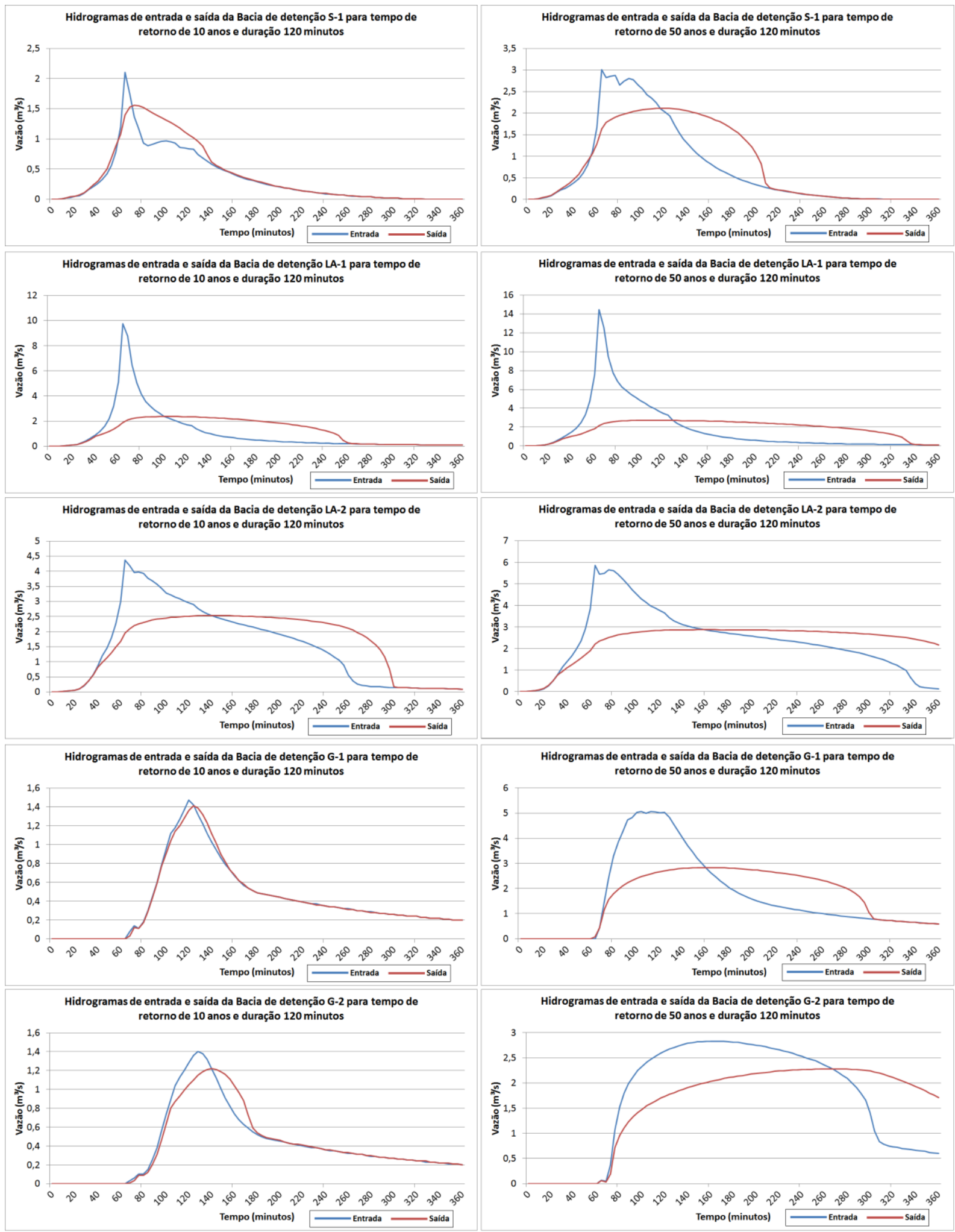

Figura 47 - Hidrogramas de entrada e saída para cada uma das 5 bacias de detenção para tempos de retorno de 10 e 50 anos

Nos hidrogramas apresentados na Figura 47, pode-se observar que as bacias de detenção cumprem o papel de amortecer os hidrogramas locais e, consequentemente, ajudam a amenizar a vazão de pico no hidrograma da bacia. No 
entanto, as bacias G-1 e G-2, que recebem vazão de uma área predominantemente rural, tem eficiência discreta no controle de pico de vazão, principalmente pela baixa vazão na entrada dos dispositivos. No caso específico do reservatório G-1, o maior de todos os reservatórios, praticamente não se nota efeito real do dispositivo no hidrograma de saída para o tempo de retorno de 10 anos, o que faz pouca diferença no hidrograma da bacia do Gregório, uma vez que o pico do hidrograma afluente é de apenas pouco mais de $1,4 \mathrm{~m}^{3} / \mathrm{s}$.

Desta forma, nota-se que apesar de cumprirem o papel para o qual foram dimensionados, a magnitude dos hidrogramas de entrada e saída dos reservatórios é muito inferior à magnitude dos hidrogramas da bacia hidrográfica. Como exemplo, cita-se o pico de vazão afluente do reservatório LA-2 para TR 10 e duração 120 minutos, cerca de $10 \mathrm{~m}^{3} / \mathrm{s}$. Sendo o pico do hidrograma na saída do reservatório cerca de $2,5 \mathrm{~m}^{3} / \mathrm{s}$, nota-se um amortecimento de hidrograma bastante significativo. Porém, se analisarmos o hidrograma para os mesmos TR10 e duração 120 minutos no exutório da bacia do Gregório, o pico ultrapassa os $168 \mathrm{~m} 3 / \mathrm{s}$, o que faz os com que a redução promovida pelas bacias de detenção se torne pouco significativa, uma vez que os cinco reservatórios de detenção trabalhando em conjunto só foram capazes de reduzir o pico da vazão para $159,54 \mathrm{~m}^{3} / \mathrm{s}$. Portanto, constata-se que os reservatórios de detenção, por serem localizados muito à montante da bacia, são eficientes apenas localmente, apresentando desempenho insatisfatório em nível de bacia hidrográfica.

Neste contexto, Decina (2012), analisando cenários baseados no PDDUAS na área de estudo, concluiu que, apesar de eficazes, as bacias de detenção previstas no plano diretor são incapazes de mitigar os efeitos da urbanização na bacia hidrográfica do Gregório. Em complemento, Emerson, Welty e Travor (2006) afirmam que, apesar de o dimensionamento de bacias de detenção ocorrer caso-a-caso e em escala local, a decisão de construção de uma bacia deve ocorrer depois de se averiguar a eficiência do dispositivo na escala de bacia hidrográfica, principalmente se houverem outros dispositivos de detenção na mesma bacia hidrográfica. Além disso, em um estudo realizado em uma bacia hidrográfica com mais de 100 bacias de detenção (todas entre 2 e 100 anos de tempo de retorno), os autores afirmam que, trabalhando em conjunto e de forma desordenada, as bacias de detenção podem até mesmo aumentar a vazão de pico de eventos de baixo tempo de retorno. 
Quanto ao posicionamento, Zhen, Yu e Lin (2004) afirmam que a otimização do posicionamento de estruturas de detenção de grande escala é fundamental e pode aumentar significativamente a eficiência do conjunto de técnicas compensatórias. O posicionamento dos reservatórios no PDDUAS deixa em evidência a dificuldade de se planejar estruturas de grande porte em áreas densamente urbanizadas já que, aparentemente, a disponibilidade de espaço foi o fator preponderante para a escolha do local da obra. Porém, apesar da escolha de áreas menos desenvolvidas para a instalação das bacias possivelmente diminuir seu potencial de mitigação de inundações, o aporte de água de regiões não urbanizadas pode diminuir alguns dos problemas normalmente encontrados em bacias de detenção brasileiras, como presença de resíduos sólidos e baixa qualidade de água, o que pode até mesmo transformar o reservatório em uma questão de saúde pública (SILVÉRIO \& URBINATTI, 2011; NASCIMENTO et al., 1999).

Aprofundando-se neste contexto, a fim de se investigar o grau de influência do posicionamento das bacias de detenção no hidrograma da bacia hidrográfica do córrego do Gregório, dois testes complementares foram realizados. Nestes testes, foram criados dois cenários de bacias de detenção alternativos. No primeiro, alterouse o posicionamento da maior (G-1) bacia de detenção para uma área livre próxima ao exutório da bacia hidrográfica e, no segundo cenário de bacias de detenção alternativos, alterou-se a menor (LA-2) bacia de detenção para esta área livre, localizada conforme destacado na Figura 48. Assim, o entendimento dos resultados obtidos no cenário de bacias de detenção seria facilitado pelos novos dados. 


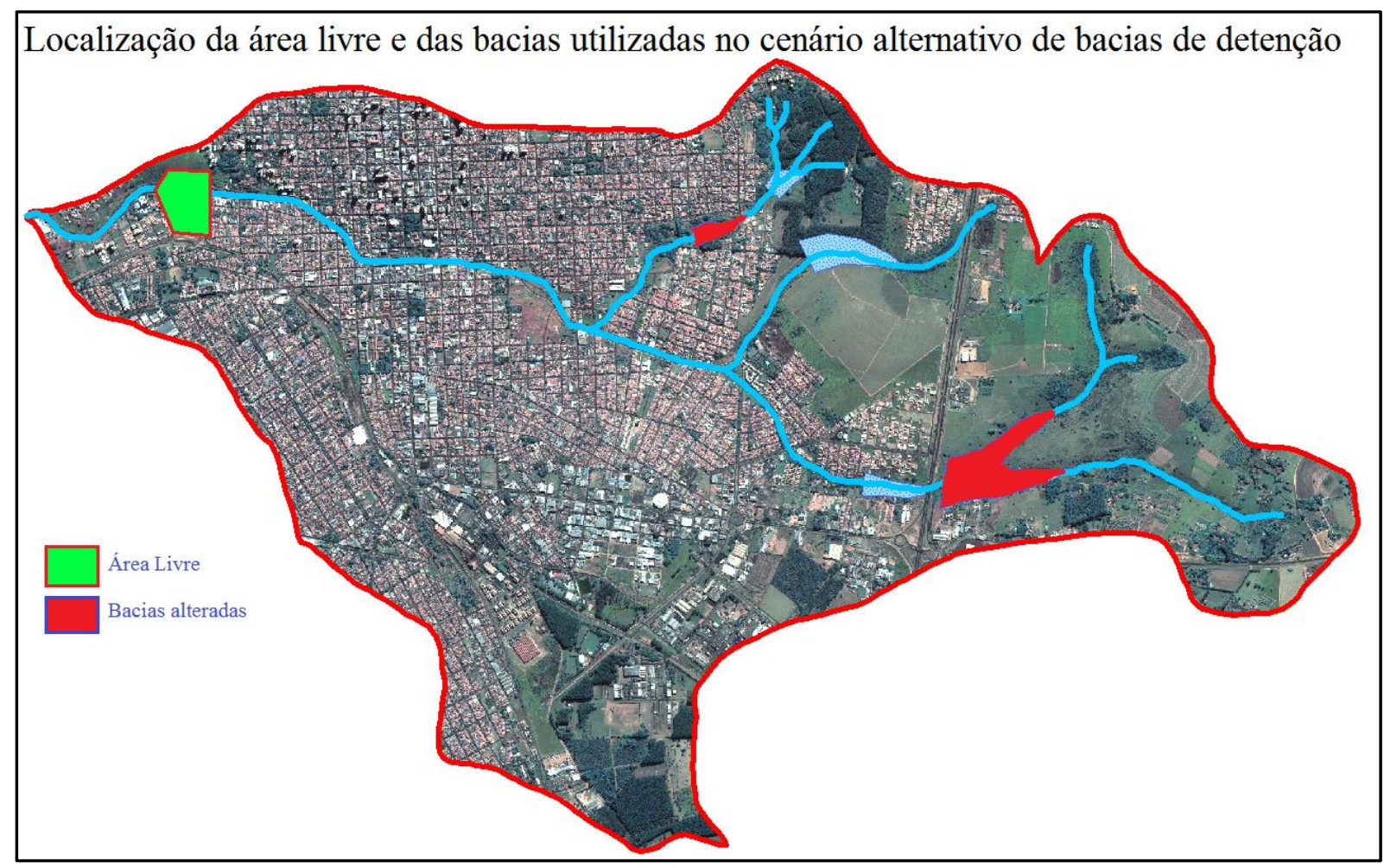

Figura 48 - Localização da maior e da menor bacia de detenção e posicionamento utilizado no cenário alternativo de bacias de detenção.

A alteração da localização das bacias de detenção produziu resultados surpreendentes, explicitando a importância do posicionamento de dispositivos centralizados nos resultados em escala de bacia hidrográfica. As reduções alcançadas - em termos de redução de vazão de pico — com o novo posicionamento, quando comparados ao cenário real, são apresentadas na Tabela 28.

Tabela 28 - Reduções de vazão de pico dos cenários alternativos de bacia de detenção em relação ao cenário real

\begin{tabular}{|cccccc|}
\hline \multicolumn{7}{c|}{ REDUÇõES DE VAZÃO DE PICO } \\
\hline Tempo de retorno & 2 & 5 & 10 & 50 & 100 \\
\hline Cenário alternativo G-1 & $16,40 \%$ & $21,07 \%$ & $23,42 \%$ & $31,27 \%$ & $36,66 \%$ \\
\hline Cenário alternativo LA-2 & $6,50 \%$ & $6,83 \%$ & $6,71 \%$ & $9,10 \%$ & $12,09 \%$ \\
\hline
\end{tabular}

Os resultados alcançados relocando-se as bacias de detenção para a área mais próxima à jusante da bacia foram consideravelmente superiores àqueles obtidos com o planejamento do PDDUAS, principalmente para o maior reservatório. Para ambos, melhores resultados foram obtidos nas maiores precipitações, o que indica 
que os dispositivos são mais eficientes em grandes tormentas. Além disso, a melhoria de resultados evidencia a dificuldade de se trabalhar com áreas densamente urbanizadas pois, apesar de ser de comum conhecimento que a aplicação de bacias de detenção seja mais recomendada mais à jusante da bacia do que à montante, provavelmente a falta de espaços e outras complicações de caráter urbano levaram à decisão da locação conforme apresentada pelo PDDUAS.

\subsubsection{Pavimento permeável}

Para o cenário com a aplicação extensiva de pavimentos permeáveis na bacia do Gregório, as vazões de pico e a comparação dos hidrogramas resultantes da simulação para diferentes tempos de retorno com precipitações de 120 minutos são apresentados nas Tabelas 28 e 29.

Tabela 29 - Valores de vazão de pico $\left(\mathrm{m}^{3} / \mathrm{s}\right)$ para o exutório da bacia e para o a região do mercado para precipitações de 120 minutos de duração no cenário de pavimento permeáveis

\begin{tabular}{cccccc}
\hline Tempo de retorno & $\mathbf{2}$ & $\mathbf{5}$ & $\mathbf{1 0}$ & $\mathbf{5 0}$ & $\mathbf{1 0 0}$ \\
\hline Exutório & 89,63 & 117,16 & 147,11 & 231,99 & 314,66 \\
Mercado & 75,27 & 99,28 & 123,16 & 200,43 & 287,64 \\
\hline
\end{tabular}

Tabela 30 - Comparação entre hidrogramas do cenário de pavimentos permeáveis em relação ao cenário real

\begin{tabular}{ccccc}
\hline $\begin{array}{c}\text { Tempo de retorno } \\
\text { (120min duração) }\end{array}$ & $\begin{array}{c}\text { Redução vazão } \\
\text { de pico (\%) }\end{array}$ & $\begin{array}{c}\text { Redução tempo } \\
\text { de pico (\%) }\end{array}$ & $\begin{array}{c}\text { Redução } \\
\text { volume (\%) }\end{array}$ & $\begin{array}{c}\text { Redução de } \\
\text { volume }\left(\mathbf{m}^{\mathbf{3}}\right)\end{array}$ \\
\hline $\mathbf{2}$ & 13,09 & 2,00 & 16,30 & $49.346,10$ \\
$\mathbf{5}$ & 14,10 & 2,04 & 13,77 & $55.158,30$ \\
$\mathbf{1 0}$ & 12,50 & 0,00 & 11,80 & $59.214,60$ \\
$\mathbf{5 0}$ & 14,83 & 0,00 & 8,76 & $73.735,20$ \\
\hline $\mathbf{1 0 0}$ & 8,81 & 2,08 & 8,17 & $85.685,40$ \\
\hline
\end{tabular}

$\mathrm{Na}$ comparação apresentada, nota-se uma redução de vazão de pico ao redor de $13 \%$ para os tempos de retorno de 2, 5, 10 e 50 anos. Para o maior tempo de retorno, 100 anos, a redução foi menor, cerca de $8,81 \%$.

Com relação à redução nos volumes de hidrogramas, os volumes absolutos retidos pelos dispositivos foram maiores quanto maiores os eventos, o que indica que até mesmo para os eventos de tempo de retorno de 50 anos a capacidade de retenção 
dos dispositivos não foi esgotada pois, neste caso, atribuiu-se todas as diferenças de volume aos volumes armazenados e infiltrados pelos dispositivos. Esta capacidade ampla pode ser devido à adoção de uma espessura da camada de armazenamento $(150 \mathrm{~mm})$ muito superior àquela dimensionada para a tormenta de projeto $(63,5 \mathrm{~mm})$. Apesar disso, percentualmente em relação ao volume total de hidrograma, os valores de redução de volume diminuíram à medida que os eventos se tornaram mais intensos.

Analisando-se o desempenho dos pavimentos permeáveis na simulação hidrológica, para os tempos de retorno de 2, 5 e 10 anos, não houve produção de escoamento pelo pavimento e toda a lâmina precipitada sobre o dispositivo foi armazenada e infiltrada durante o período de 6 horas analisado. Para o tempo de retorno de 50 anos ainda havia uma lâmina de água (apenas 3,66 mm) armazenada após as seis horas, mas não houve produção de escoamento sobre o pavimento permeável. Porém, para o tempo de retorno de 100 anos houve produção de escoamento superficial nos dispositivos $(5,78 \mathrm{~mm}$ escoado dos $91,12 \mathrm{~mm}$ precipitados), além de uma lâmina de água ainda armazenada no dispositivo 6 horas após o início do evento $(11,11 \mathrm{~mm})$.

Em solos permeáveis, é comum que pavimentos permeáveis tenham capacidade de infiltrar grandes lâminas de precipitação. Booth e Leavitt (1999), em um monitoramento realizado durante seis anos em quatro diferentes tipos de pavimentos permeáveis, jamais registraram qualquer produção de escoamento superficial nos dispositivos.

Em pavimentos permeáveis, durante grandes eventos (como de 100 anos) a produção de escoamento superficial pode ocorrer se a capacidade de infiltração de alguma das camadas do pavimento for superada ou se a capacidade de armazenamento for excedida. Coughlin, Campbel e Mays, (2012), analisando o desempenho em laboratório de pavimentos permeáveis em solos arenosos e argilosos concluíram que, mesmo após considerável colmatação, os pavimentos sobre os dois tipos de solo foram capazes de absorver uma precipitação de intensidade de $66 \mathrm{~mm} / \mathrm{h}$, tendo como fatores limitantes à absorção de precipitações superiores a esta a capacidade de infiltração do solo e da camada de armazenamento utilizada, uma areia muito fina. Em complemento, Abbott e Mateos (2003) afirmam que, embora possa haver produção de escoamento na superfície ou saída de água por drenos existentes nos sistemas de pavimentos permeáveis, a magnitude da vazão de saída é 
consideravelmente menor que as lâminas de água absorvidas pelo pavimento, o que os torna dispositivos de excelente desempenho no controle do escoamento superficial.

Para a região do mercado municipal, foram comparados os hidrogramas de tempo de retorno de 2, 10 e 50 anos do cenário de pavimento permeável com relação ao cenário real (Tabela 30).

Tabela 31 - Comparação de valores de referência entre hidrogramas do cenário de pavimentos permeáveis e cenário real para a região do mercado municipal

\begin{tabular}{cccc} 
Tempo de retorno & $\begin{array}{c}\text { Redução vazão } \\
\text { de pico (\%) }\end{array}$ & $\begin{array}{c}\text { Redução } \\
\text { volume (\%) }\end{array}$ & $\begin{array}{c}\text { Redução de } \\
\text { volume }\left(\mathbf{m}^{\mathbf{3}}\right)\end{array}$ \\
\hline $\mathbf{1 2 0}$ in duração) & 9,82 & 16,52 & $40.177,80$ \\
$\mathbf{1 0}$ & 12,35 & 10,99 & $44.488,80$ \\
$\mathbf{5 0}$ & 13,23 & 8,03 & $55.505,70$ \\
\hline
\end{tabular}

Os resultados de redução de vazão de pico foram levemente inferiores à redução observada no exutório da bacia hidrográfica, mas ainda são positivos. Neste caso, semelhantemente ao resultado obtido para o exutório da bacia, as reduções de vazão de pico e de volume de hidrogramas foram maiores para as precipitações maiores, como a de 10 e 50 anos. De modo geral, por se tratarem de dispositivos de controle de produção de escoamento que, neste caso, não receberam escoamento de outras áreas, constata-se que os pavimentos permeáveis são apropriados para combaterem a produção de escoamento de eventos frequentes e raros e que, na escala de bacia hidrográfica, são capazes de produzir melhoras significativas na redução de escoamento superficial e aumento da infiltração das águas pluviais. 


\subsubsection{Jardins de chuva}

Para o cenário com a implantação de jardins de chuva lineares de maneira extensiva na bacia hidrográfica, foram gerados hidrogramas para diferentes tempos de retorno com duração de 60 e 120 minutos, e novamente não houve diferenças significativas para vazão de pico e volumes escoados entre mesmos tempos de retorno e diferentes durações. Portanto, apenas precipitações de 120 minutos de duração foram utilizadas na comparação do cenário de jardins de chuva com o cenário real apresentada na Tabela 31 .

Tabela 32 - Comparação entre hidrogramas do cenário de jardins de chuva lineares em relação ao cenário real

\begin{tabular}{ccccc}
$\begin{array}{c}\text { Tempo de retorno } \\
(\mathbf{1 2 0 m i n} \text { duração) }\end{array}$ & $\begin{array}{c}\text { Redução vazão } \\
\text { de pico (\%) }\end{array}$ & $\begin{array}{c}\text { Redução tempo } \\
\text { de pico (\%) }\end{array}$ & $\begin{array}{c}\text { Redução } \\
\text { volume (\%) }\end{array}$ & $\begin{array}{c}\text { Redução de } \\
\text { volume }\left(\mathbf{m}^{\mathbf{3}}\right)\end{array}$ \\
\hline $\mathbf{2}$ & 0,80 & 2,00 & 3,68 & $11.146,50$ \\
$\mathbf{5}$ & 0,49 & 2,04 & 2,85 & $11.419,20$ \\
\hline $\mathbf{1 0}$ & 1,75 & 0,00 & 2,33 & $11.683,80$ \\
$\mathbf{5 0}$ & 0,17 & 0,00 & 1,43 & $12.029,40$ \\
\hline $\mathbf{1 0 0}$ & 0,12 & 2,08 & 1,12 & $11.728,80$ \\
\hline
\end{tabular}

O resultado dos jardins de chuva na redução de vazões de pico dos hidrogramas foi pouco significativa, bem como a redução do volume dos hidrogramas de cheia. Com relação à área do mercado municipal, os resultados são apresentados na Tabela 32.

Tabela 33 - Comparação de valores de referência entre hidrogramas do cenário de jardins de chuva e cenário real para a região do mercado municipal

\begin{tabular}{cccc}
$\begin{array}{c}\text { Tempo de retorno } \\
\text { (120min duração) }\end{array}$ & $\begin{array}{c}\text { Redução vazão } \\
\text { de pico (\%) }\end{array}$ & $\begin{array}{c}\text { Redução } \\
\text { volume (\%) }\end{array}$ & $\begin{array}{c}\text { Redução de } \\
\text { volume ( } \mathbf{m}^{\mathbf{3}} \text { ) }\end{array}$ \\
\hline $\mathbf{2}$ & 0,60 & 3,65 & $8.887,50$ \\
$\mathbf{1 0}$ & 0,19 & 2,27 & $9.182,70$ \\
$\mathbf{5 0}$ & 0,00 & 1,39 & $9.586,80$ \\
\hline
\end{tabular}

O desempenho dos jardins de chuva em escala de bacia hidrográfica para a área do mercado municipal foi igualmente ruim, mantendo-se sempre abaixo de $1 \%$ de redução de vazão de pico. Ao se analisar o desempenho individual dos jardins de chuva apresentados pelo programa SWMM, foi verificado que os jardins de chuva 
tiveram bom desempenho no controle do escoamento, retendo cerca de $40 \mathrm{~mm}$ de escoamento durante os eventos chuvosos. Analisando-se as camadas que compuseram os jardins de chuva, constatou-se que a camada de solos localizada na superfície dos dispositivos possuía taxas de infiltração muito inferiores à taxa de infiltração do material da camada de armazenamento, mas mesmo assim retiveram um volume adequado de escoamento.

Ademais, foram feitos alguns testes com maiores valores de taxas de infiltração para a camada de solo para melhor entender a dinâmica de seu funcionamento em escala de dispositivo e de bacia. O resultado dos testes indicou que, mesmo quando não houve limitação da infiltração na camada de terra e toda a camada de armazenamento dos jardins de chuva foi preenchida $(1000 \mathrm{~mm})$, as reduções de vazão de pico não chegaram a $2 \%$, em escala de bacia, para nenhuma das precipitações. Desta forma, concluiu-se que os jardins de chuva, conforme dimensionados neste trabalho, se mostraram ineficientes no combate ao escoamento superficial mais pela insuficiência no número e área dos dispositivos do que pela eficiência do próprio dispositivo, embora a eficiência individual dos dispositivos não tenha sido adequada.

Em contrapartida, diversos trabalhos abordaram o uso de jardins de chuva no controle do escoamento e relataram efeitos bastante positivos. Autixier et al. (2014) obtiveram, através de simulação hidrológica de cenários hipotéticos, uma faixa de redução entre 7 e 56\% na redução da vazão de pico de 5 deferentes áreas de estudo analisadas. Porém, os autores utilizaram uma área de estudos com disponibilidade de espaço bastante superior à bacia hidrográfica do Gregório, de modo que a aplicação de jardins de chuva foi bastante extensiva. James e Dymmond (2012), através de cenários e modelos hidrológicos, simularam a implementação de jardins de chuva em uma bacia hidrográfica urbana de 154 hectares nos Estados Unidos, e obtiveram reduções máximas de $74 \%$ na vazão de pico para pequenos eventos com tempo de retorno próximos a um ano, além de uma redução de $22 \%$ na vazão de pico para uma precipitação de 50 anos de tempo de retorno. Entretanto, no mesmo trabalho não foram obtidos bons resultados em um cenário em que os jardins tratavam escoamento superficial proveniente de grandes áreas impermeáveis e, segundo os autores, a 
redução do volume de escoamento pôde ser considerada insignificante para este caso.

Para áreas com disponibilidade de espaço, os jardins de chuva podem ser eficientes no controle do escoamento superficial. Em estudos de caso, DeBusk e Wynn (2011) e Davis (2008), construindo jardins de chuva para receber água de estacionamentos automotivos, obtiveram reduções máximas entre 54\% e $91 \%$ na vazão de pico das áreas tratadas pelos dispositivos para diferentes precipitações.

Além disso, os jardins de chuva possuem papel fundamental na melhoria da água de escoamento, tratando principalmente a parcela de first-flux com bons níveis de redução de concentração de alguns poluentes como alguns metais e macronutrientes (nitrogênio e fósforo), mas principalmente dos sólidos suspensos totais (AUTIXIER et al., 2014; GASPERI et al, 2010; MAILHOT et al, 2008).

Assim, pode-se afirmar que os jardins de chuva podem ser dispositivos eficientes para controle de escoamento superficial. Porém, para o atual trabalho, devido às condições da área de estudos - passeios públicos estreitos, irregulares e com presença constante de degraus, o que levou a um dimensionamento conservador dos dispositivos - estes dispositivos não foram eficientes no combate ao escoamento superficial e redução de volume de hidrogramas da bacia.

\subsubsection{Telhados verdes}

Nas simulações realizadas, os resultados mostram que os telhados verdes tiveram melhores desempenhos em precipitações menores do que em precipitações maiores. Para tempos de retorno de 2 anos e duração de precipitação de 120 minutos, os telhados verdes armazenaram 15,77mm (43,55\%) dos 36,21 precipitados. Para uma precipitação de 100 anos de tempo de retorno, os telhados armazenaram os mesmos 15,77mm (17,30\%) para uma precipitação de 91,12mm. Estes resultados expressam um baixo desempenho individual dos telhados verdes nas simulações, mesmo tendo capacidade para reter $58,95 \mathrm{~mm}$, conforme relatado no sub-capítulo 4.8.5. Sobre isso, Burszta-Adamiak e Mrowiec (2013), após compararem o desempenho isolado de telhados verdes experimentais com resultados simulados no SWMM, sugerem que os resultados individuais dos telhados no modelo são bastante insatisfatórios e tendem a aumentar consideravelmente a quantidade de escoamento superficial produzido em relação aos valores reais, principalmente pela simplicidade 
excessiva com que o modelo realiza o balanço hídrico nos telhados verdes. Neste contexto, Qin, Li e Fu (2013), analisando a sensibilidade dos parâmetros de telhados verdes no hidrograma de uma pequena bacia utilizando modelagem hidrológica, concluíram também que telhados verdes conforme representados no SWMM são insatisfatórios se analisados individualmente. Porém, os autores revelam que a técnica compensatória possui um baixo desempenho muitas vezes equivocado se analisado isoladamente, uma vez que o software simula a atuação do dispositivo no balanço hídrico da bacia não somente pelos parâmetros da técnica compensatória, mas também pelas mudanças nos parâmetros que caracterizam a bacia no modelo como, por exemplo, largura da bacia e percentual de áreas impermeáveis. Desta forma, após validarem os resultados de suas simulações, os autores concluíram que apesar do desempenho incoerente dos dispositivos simulados isoladamente, no contexto da bacia hidrográfica o modelo possui bons resultados na representação de interações entre telhados verdes e bacias hidrográficas, produzindo, portanto, hidrogramas representativos.

Visto isso, avalia-se a seguir o desempenho dos telhados verdes em escala de bacia hidrográfica. Para precipitações de 120 minutos, considerando o cenário com $25 \%$ dos telhados sendo representados por telhados verdes, os resultados são apresentados na Tabela 33.

Tabela 34 - Comparação entre hidrogramas do cenário de telhados verdes em relação ao cenário real

\begin{tabular}{ccccc}
$\begin{array}{c}\text { Tempo de retorno } \\
\text { (120min duração) }\end{array}$ & $\begin{array}{c}\text { Redução vazão } \\
\text { de pico (\%) }\end{array}$ & $\begin{array}{c}\text { Redução tempo } \\
\text { de pico (\%) }\end{array}$ & $\begin{array}{c}\text { Redução } \\
\text { volume (\%) }\end{array}$ & $\begin{array}{c}\text { Redução de } \\
\text { volume }\left(\mathbf{m}^{\mathbf{3}}\right)\end{array}$ \\
\hline $\mathbf{2}$ & 16,37 & 2,00 & 10,51 & $31.815,90$ \\
$\mathbf{5}$ & 16,33 & 2,04 & 7,38 & $29.580,30$ \\
$\mathbf{1 0}$ & 13,19 & 0,00 & 8,37 & $41.998,50$ \\
$\mathbf{5 0}$ & 12,11 & 0,00 & 2,69 & $22.607,10$ \\
$\mathbf{1 0 0}$ & 12,77 & 2,08 & 1,78 & $18.702,90$ \\
\hline
\end{tabular}

Nota-se pela tabela que os telhados verdes tiveram um efeito positivo no controle de escoamento na bacia hidrográfica, com reduções significativas no valor do pico e volume dos hidrogramas. Quanto à vazão de pico, uma redução significativa ocorreu em todas as situações, sendo maiores as reduções quanto menores as precipitações. Apesar disso, a variação detectada entre os tempos de retorno de 2 e 
100 anos pode ser considera baixa (3,6\%), o que indica que os dispositivos tiveram desempenho consistente no controle de escoamento superficial.

Em relação ao tempo de pico, embora pudesse ser esperado um atraso no instante de pico com a utilização extensiva de telhados verdes, este atraso não ocorreu. Carter e Jackson (2007), utilizando o mesmo modelo SWMM na simulação de telhados verdes em escala de bacia, também não detectaram atraso no tempo de pico do hidrograma, embora tenham relatado grandes reduções de valores de vazão e volume de escoamento, além de aumento nos valores de vazão da curva descendente do hidrograma.

Para a área do mercado municipal, alguns resultados de comparação de hidrogramas são apresentados na Tabela 34. Apresenta-se também, para comparação, os valores de vazão de pico para os hidrogramas do cenário de telhados verdes na Tabela 35.

Tabela 35 - Comparação de valores de referência entre hidrogramas do cenário de telhados verdes e cenário real para a região do mercado municipal

\begin{tabular}{cccc}
$\begin{array}{c}\text { Tempo de } \\
\text { retorno }\end{array}$ & $\begin{array}{c}\text { Redução vazão } \\
\text { de pico (\%) }\end{array}$ & $\begin{array}{c}\text { Redução } \\
\text { volume }(\%)\end{array}$ & $\begin{array}{c}\text { Redução de } \\
\text { volume }\left(\mathbf{m}^{\mathbf{3}}\right)\end{array}$ \\
\hline $\mathbf{2}$ & 15,43 & 8,53 & $16.911,00$ \\
$\mathbf{1 0}$ & 14,14 & 2,65 & $8.692,20$ \\
$\mathbf{5 0}$ & 15,54 & 10,98 & $26.712,00$ \\
\hline
\end{tabular}

Tabela 36 - Valores de vazão de pico $\left(\mathrm{m}^{3} / \mathrm{s}\right)$ para o exutório da bacia e para o a região do mercado para precipitações de 120 minutos de duração no cenário de telhados verdes

\begin{tabular}{cccccc} 
Tempo de retorno & $\mathbf{2}$ & $\mathbf{5}$ & $\mathbf{1 0}$ & $\mathbf{5 0}$ & $\mathbf{1 0 0}$ \\
\hline Exutório & 86,25 & 116,73 & 145,98 & 245,51 & 306,39 \\
Mercado & 70,50 & 94,79 & 120,28 & 204,14 & 243,80 \\
\hline
\end{tabular}

A redução das vazões de pico na região do mercado municipal se mantiveram praticamente constantes em torno de $15 \%$. Já a redução de volume apresentou variações inesperadas entre os diferentes tempos de retorno. Mesmo assim, exceto pelo valor apresentado para TR 10 anos, nota-se que os valores retidos pelos telhados verdes são menores quanto maiores as precipitações, padrão também observado nos hidrogramas do exutório da bacia. Esta relação entre retenção de telhados verdes e a intensidade da precipitação já foi investigada em uma série de estudos. Carter e Rasmussem (2006), em telhados verdes experimentais, relataram uma relação inversa entre lâmina precipitada e lâmina retida, nos quais para precipitações 
pequenas $(25,4 \mathrm{~mm})$ a retenção foi de $88 \%$, eventos médios $(25,4$ a $76,2 \mathrm{~mm})$ a retenção foi de $54 \%$ e grandes eventos $(>76,2 \mathrm{~mm}) 48 \%$ foram retidos. No mesmo sentido, Simmons et al. (2008) relatou a mesma relação inversa, apresentando valores de retenção de $100 \%$, $88 \%$ e $43 \%$ para precipitações de até $10 \mathrm{~mm}, 12 \mathrm{~mm}$ e até $49 \mathrm{~mm}$, respectivamente. Além disso, os autores afirmam que a retenção de água não depende apenas do tamanho da lâmina precipitada, mas também da intensidade da precipitação. Por fim, Villareal e Bengtsson (2005) afirmam que a retenção de telhados verdes depende diretamente da intensidade da precipitação, sendo menor a retenção quanto maior a intensidade.

Nos estudos apresentados, todos os valores percentuais de retenção são obtidos comparando-se a lâmina precipitada com a lâmina retida. No atual trabalho, conforme relatado no início deste capitulo, os telhados verdes apresentam um padrão semelhante, sendo menor a retenção quanto maior a precipitação. Isto ocorre porque a capacidade dos dispositivos é limitada basicamente pelo tipo de substrato e sua espessura.

Para uma análise mais detalhada dos efeitos dos telhados verdes na bacia hidrográfica, apresenta-se a seguir uma comparação dos hidrogramas do cenário real e para o cenário com telhados verdes para a região do mercado municipal na Figura 49. 


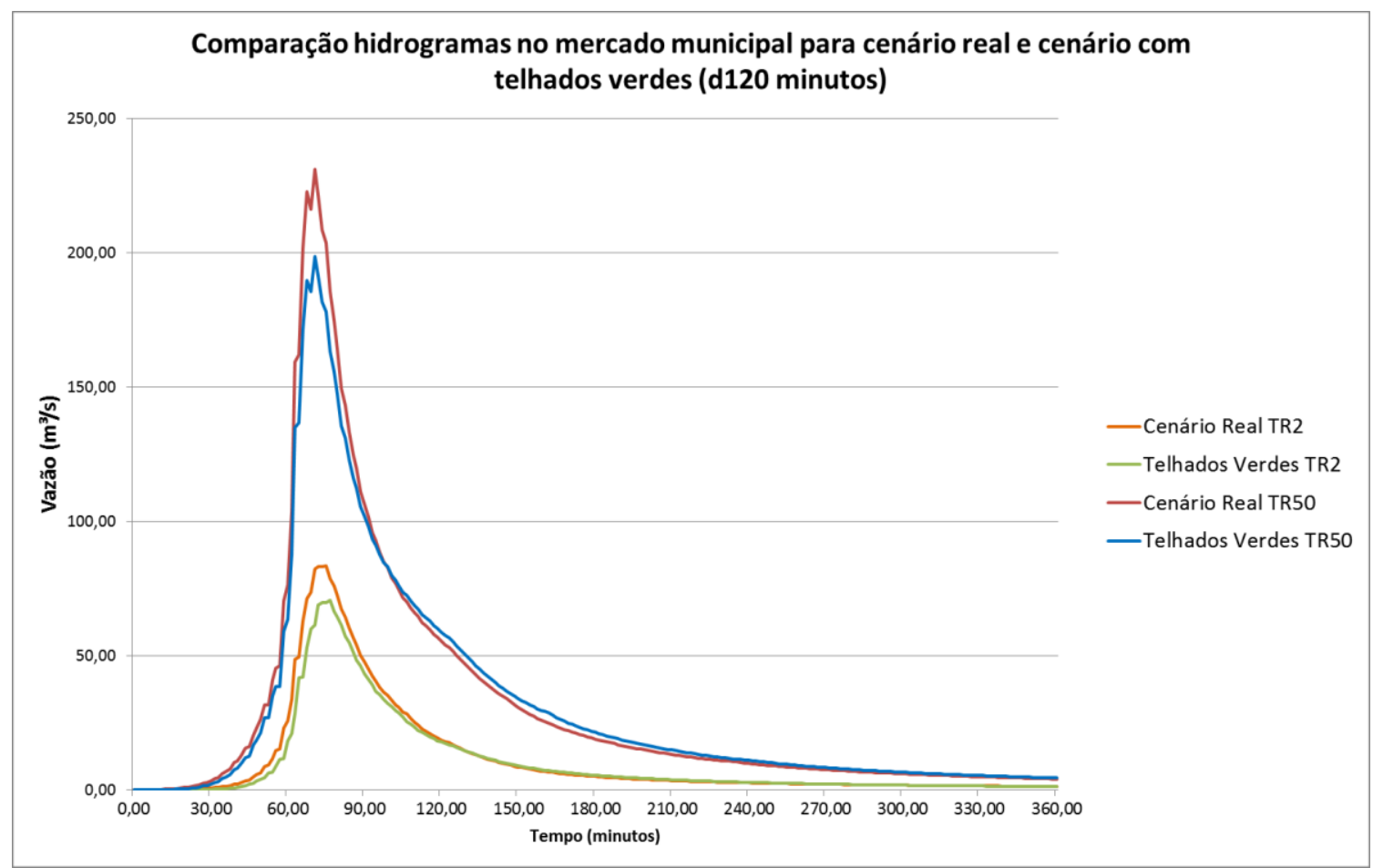

Figura 49 - Comparação dos hidrogramas do cenário real e do cenário com telhados verdes

A redução de vazão, em valores absolutos, foi maior para precipitações maiores, já que para o tempo de retorno de 2 anos a vazão decaiu $16,88 \mathrm{~m}^{3} / \mathrm{s}$ (de 103,13 para $86,25 \mathrm{~m}^{3} / \mathrm{s}$ ) e para as o tempo de retorno de 50 anos a vazão decaiu $25,88 \mathrm{~m}^{3} / \mathrm{s}$ (de 271,39 para $245,51 \mathrm{~m}^{3} / \mathrm{s}$ ). Analisando-se o formato do hidrograma, pode-se notar o efeito dos telhados verdes para precipitações de pequeno e grande volume. Em telhados verdes, o volume precipitado é absorvido assim que incide sobre sua superfície. Caso a precipitação seja pequena, a maior parte do volume que cai sobre o telhado é absorvida e retida. Em precipitações muito intensas, parte é infiltrada e parte é escoada superficialmente pelo telhado. O volume infiltrado, caso exceda a capacidade de retenção dos telhados, volta ao sistema de drenagem através da manta de drenagem instalada ao fundo do dispositivo. Este processo de percolação e drenagem dos dispositivos retarda o tempo de percurso da água, amortecendo o pico dos hidrogramas. Ao fim da precipitação, o telhado verde mantém temporariamente um volume superior à capacidade de campo do substrato devido à saturação do mesmo.

Visto isso, pelo hidrograma apresentado (Figura 49) nota-se que para a precipitação com tempo de retorno de 2 anos, a parcela de água absorvida pelo telhado verde praticamente não retorna à rede de drenagem. No hidrograma de 50 anos, o volume de água que foi reduzido durante o pico do hidrograma pelos telhados 
verdes retorna ao sistema durante a curva descendente, momento no qual a vazão do cenário de telhados verdes se torna superior à vazão do cenário real. Desta forma, mesmo a redução no volume do hidrograma sendo menor, o amortecimento no pico da vazão ainda ocorre de maneira expressiva.

De maneira geral, por se tratarem de dispositivos de controle na fonte, os telhados verdes se mostraram alternativas eficientes no controle de escoamento superficial urbano, e podem apresentar melhores resultados quanto maiores as áreas em que forem aplicados. Além disso, pela possibilidade de serem aplicados em praticamente qualquer telhado, são adequados para a adaptação de áreas densamente urbanizadas aos princípios da drenagem sustentável. Mentens, Raes e Hemry (2006) apontam os telhados verdes como grandes alternativas para a solução dos problemas urbanos relacionados ao excesso de escoamento superficial.

\subsubsection{Trincheiras de infiltração lineares}

Os resultados da simulação do cenário com trincheiras de infiltração em relação ao cenário real da bacia do gregório são apresentados na Tabela 36. 
Avaliação do potencial de aplicação de técnicas compensatórias em áreas urbanas consolidadas

Tabela 37 - Comparação entre hidrogramas do cenário de trincheiras de infiltração lineares em relação ao cenário real

\begin{tabular}{ccccc}
$\begin{array}{c}\text { Tempo de retorno } \\
\text { (120min duração) }\end{array}$ & $\begin{array}{c}\text { Redução vazão } \\
\text { de pico (\%) }\end{array}$ & $\begin{array}{c}\text { Redução tempo } \\
\text { de pico (\%) }\end{array}$ & $\begin{array}{c}\text { Redução } \\
\text { volume (\%) }\end{array}$ & $\begin{array}{r}\text { Redução de } \\
\text { volume (m } \mathbf{m}^{\mathbf{3}}\end{array}$ \\
\hline $\mathbf{2}$ & 35,50 & 12,00 & 32,48 & $98.333,10$ \\
$\mathbf{5}$ & 21,34 & 6,12 & 24,39 & $97.704,90$ \\
$\mathbf{1 0}$ & 15,23 & 4,17 & 19,97 & $100.193,40$ \\
$\mathbf{5 0}$ & 8,12 & 4,17 & 11,76 & $99.022,50$ \\
\hline $\mathbf{1 0 0}$ & 3,81 & 2,08 & 9,57 & $100.368,90$ \\
\hline
\end{tabular}

Para as precipitações com menores tempos de retorno, como 2 e 5 anos, as trincheiras de infiltração lineares se mostraram bastante eficientes para controle da vazão de pico e na redução do volume de hidrogramas de cheias. Porém, as trincheiras foram pouco eficientes para as precipitações maiores, pincipalmente para o tempo de retorno de 100 anos, para a qual a redução da vazão de pico foi de apenas $3,81 \%$, ou $13,15 \mathrm{~m}^{3} / \mathrm{s}$.

Se observado a redução do volume dos hidrogramas, nota-se que o volume retido pelos dispositivos foi praticamente o mesmo para todos os tempos de retorno. Assim, pode-se afirmar que a capacidade de retenção dos dispositivos se mantém constante independente do volume e intensidade da precipitação. Como as trincheiras de infiltração tem camadas superficiais formadas por material de alta granulometria, dificilmente suas taxas de infiltração são menores que as taxas de precipitação e, portanto, as trincheiras absorvem toda a água afluente até que sua capacidade seja atingida. Entretanto, como as trincheiras de infiltração recebem escoamento de áreas externas, a vazão de água que adentra os dispositivos pode ser muito alta e sua capacidade pode ser excedida rapidamente.

O desempenho do dispositivo em termos de lâmina infiltrada e lâmina armazenada foi praticamente o mesmo para todas as precipitações. Em um período de 6 horas desde o início da precipitação, a lâmina infiltrada ficou em torno de $75 \mathrm{~mm}$ e a lâmina armazenada ao fim da precipitação foi de aproximadamente $400 \mathrm{~mm}$. Pela equação 3 , sendo a porosidade do material granular de armazenamento igual a $40 \%$, compreende-se que toda a altura da camada de armazenamento foi preenchida por água. Como o desempenho individual das trincheiras foi semelhante para todos os tempos de retorno, a capacidade de retenção deve também ser constante e, portanto, a redução de volume e vazão de pico será proporcionalmente menor quanto maiores foram as chuvas, o que é confirmado pelos valores da Tabela 36. Por isso, as 
trincheiras de infiltração se mostraram mais eficientes no controle de vazões de pico de eventos menores em relação aos maiores. Para a região do mercado municipal, os valores da comparação com o hidrograma do cenário real e a tabela com as vazões são apresentados nas Tabelas 37 e 38.

Tabela 38 - Comparação de valores de referência entre hidrogramas do cenário de trincheiras de infiltração e cenário real para a região do mercado municipal

\begin{tabular}{cccc}
$\begin{array}{c}\text { Tempo de } \\
\text { retorno }\end{array}$ & $\begin{array}{c}\text { Redução vazão } \\
\text { de pico (\%) }\end{array}$ & $\begin{array}{c}\text { Redução } \\
\text { volume }(\%)\end{array}$ & $\begin{array}{c}\text { Redução de } \\
\text { volume }\left(\mathbf{m}^{3}\right)\end{array}$ \\
\hline $\mathbf{2}$ & 32,29 & 30,88 & $75.106,80$ \\
$\mathbf{1 0}$ & 16,73 & 18,59 & $75.222,00$ \\
$\mathbf{5 0}$ & 9,00 & 10,62 & $73.454,40$ \\
\hline
\end{tabular}

Tabela 39 - Valores de vazão de pico $\left(\mathrm{m}^{3} / \mathrm{s}\right)$ para o exutório da bacia e para o a região do mercado para precipitações de 120 minutos de duração no cenário de trincheiras de infiltração

\begin{tabular}{cccccc} 
Tempo de retorno & $\mathbf{2}$ & $\mathbf{5}$ & $\mathbf{1 0}$ & $\mathbf{5 0}$ & $\mathbf{1 0 0}$ \\
\hline Exutório & 66,52 & 107,29 & 142,53 & 250,27 & 331,90 \\
Mercado & 56,52 & 93,92 & 117,00 & 209,73 & 285,22 \\
\hline
\end{tabular}

As reduções na região do mercado municipal são consideráveis, principalmente para o tempo de retorno de 2 e 10 anos. Em todos os eventos de menor frequência as trincheiras se mostraram como dispositivos eficientes na redução de vazões e volumes, e pode-se afirmar que mesmo sozinhas - sem a associação com outras técnicas compensatórias - podem ser alternativas interessantes para controle de escoamento superficial.

Outro aspecto interessante do funcionamento das trincheiras de infiltração é o aumento da recarga das águas subterrâneas promovido pelas trincheiras, uma vez que a água armazenada durante o evento infiltra posteriormente, somando-se à água infiltrada durante as precipitações. Logo, no caso dos cenários analisados, a lâmina média infiltrada na área das trincheiras é dada pela soma dos $75 \mathrm{~mm}$ infiltrados ao longo do evento e dos $400 \mathrm{~mm}$ infiltrados posteriormente, ou seja, $475 \mathrm{~mm}$. A promoção de infiltração, além da diminuição do escoamento superficial e aumento da recarga das águas subterrâneas, diminui a salinidade de aquíferos e melhora a qualidade de água de águas subterrâneas pela absorção da água de lavagem, conhecida por firstflush (CHAHAR; GRAILLOT; GAUR, 2012). 
Neste contexto, o recebimento do first-flush deve ser um fator muito importante no planejamento de trincheiras de infiltração, uma vez que, se a qualidade da água de escoamento for ruim e se o lençol subterrâneo for muito raso, pode ocorrer a contaminação das águas subterrâneas pela água infiltrada. Assim, em áreas onde existe produção muito grande de poluição difusa, o uso das trincheiras traz riscos e só é aceitável se a distância entre o fundo dos dispositivos e o lençol freático for grande o suficiente para permitir a atenuação dos poluentes, que ocorre através de diluição, dispersão ou degradação (GOONETILLEKEA et al., 2005).

Além disso, conforme afirmam Locatelli et al. (2015), a profundidade do lençol freático afeta diretamente as taxas de infiltração dos dispositivos, uma vez que a capacidade de infiltração da trincheira varia de acordo com as condições da zona saturada e zona vadosa do solo. Os autores alertam para a formação de morros na zona saturada, nos quais formam-se elevações locais na superfície da zona saturada devido à percolação da água em taxas maiores que a absorção e dissipação da água pelo lençol freático, o que pode diminuir consideravelmente a capacidade de infiltração de uma trincheira.

No caso da área de estudos, as regiões com menores profundidades de lençol freático encontram-se mais à montante da bacia (Figura 18), região ainda não urbanizada. Por isso, estas áreas praticamente não receberam trincheiras de infiltração justamente pela ausência de malha urbana, diminuído assim o risco de contaminação do lençol freático por infiltração de poluição.

Trincheiras de infiltração, apesar de promissoras no cenário apresentado, tem desvantagens que devem receber atenção. Inicialmente, vale ressaltar que, apesar do cenário apresentado ser tecnicamente viável e da localização e quantificação dos dispositivos ser plausível devido às condições da área de estudo, foi considerada uma aplicação bastante extensiva de trincheiras na bacia, conforme pode ser visto na Figura 38. Desta forma, vale considerar que os resultados positivos alcançados na simulação só seriam alcançados caso se aplicasse as trincheiras na quantidade prevista no cenário. Em um cenário mais razoável, no qual as trincheiras seriam aplicadas em menor escada - devido, por exemplo, à falta de recursos, dificuldade de se realizar obras de tal porte em centros urbanos, dificuldades técnicas não previstas etc. - as reduções de vazão de pico e volume ocorreriam em menor escala. Outro ponto a ser considerado é o tempo de vida útil destes dispositivos ou a redução da capacidade de infiltração dos dispositivos ao longo dos anos. 
Devido à colmatação, trincheiras de infiltração sofrem redução na sua capacidade de infiltração ao longo dos anos, podendo eventualmente reduzir sua infiltração a níveis desprezíveis. Por isso, estes dispositivos necessitam de manutenção adequada para que tenham prolongamento de sua vida útil. É certo que mesmo com capacidade de infiltração reduzida as trincheiras funcionam como dispositivos de detenção. Entretanto, o tempo de esvaziamento de uma trincheira é fator fundamental para o combate de inundações, uma vez que se a trincheira não for esvaziada entre um evento e outro, esta perde sua função (CHAHAR; GRAILLOT; GAUR, 2012; BERGMAN et al., 2010).

Para melhor entendimento do efeito das trincheiras de infiltração no hidrograma da bacia hidrográfica, são apresentados nas Figuras 49 e 50 uma comparação entre hidrogramas gerados para o cenário real e o cenário de trincheiras de infiltração.

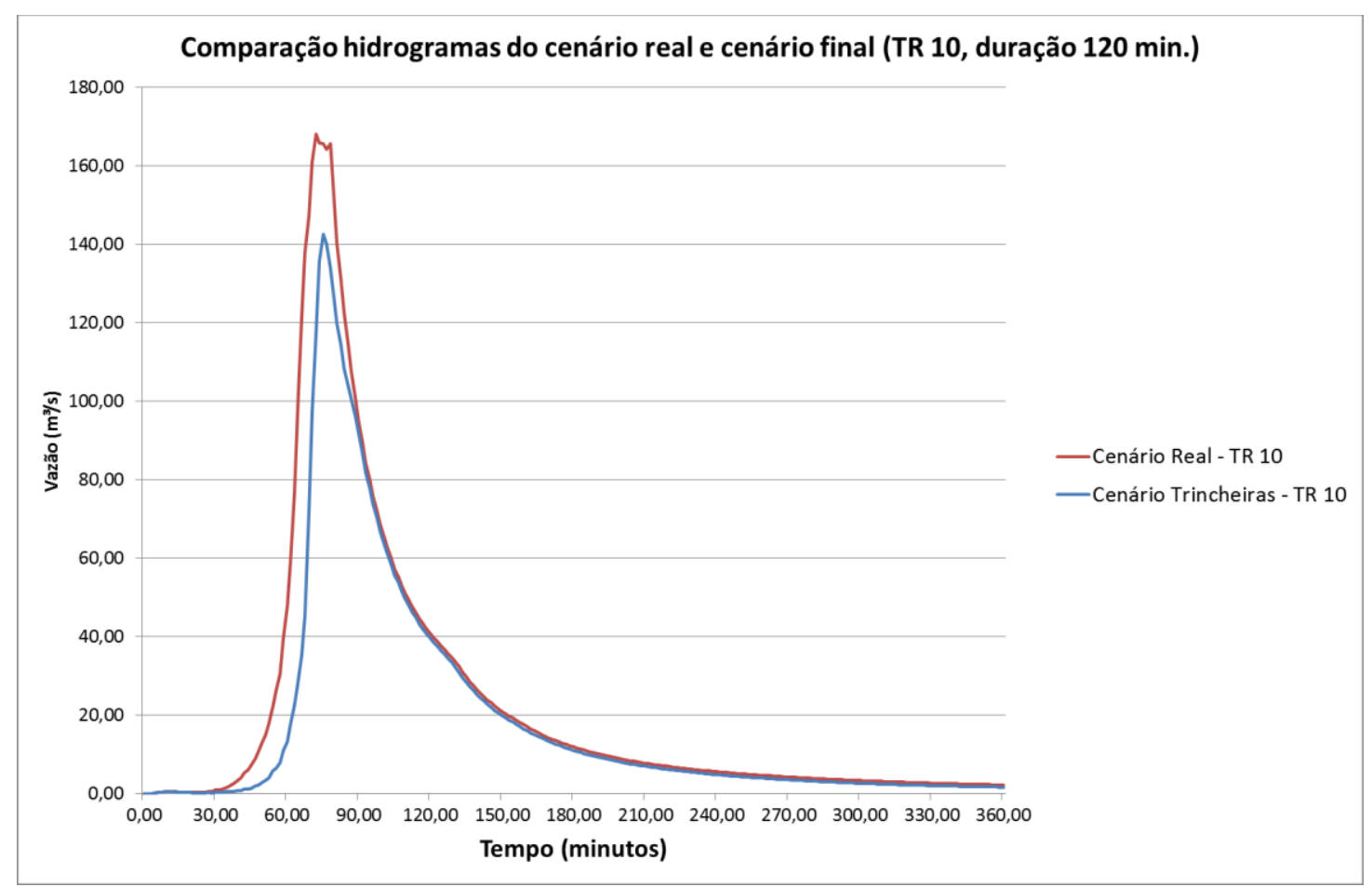

Figura 50 - Comparação entre hidrogramas do cenário real e do cenário de trincheiras de infiltração para TR 10 anos 


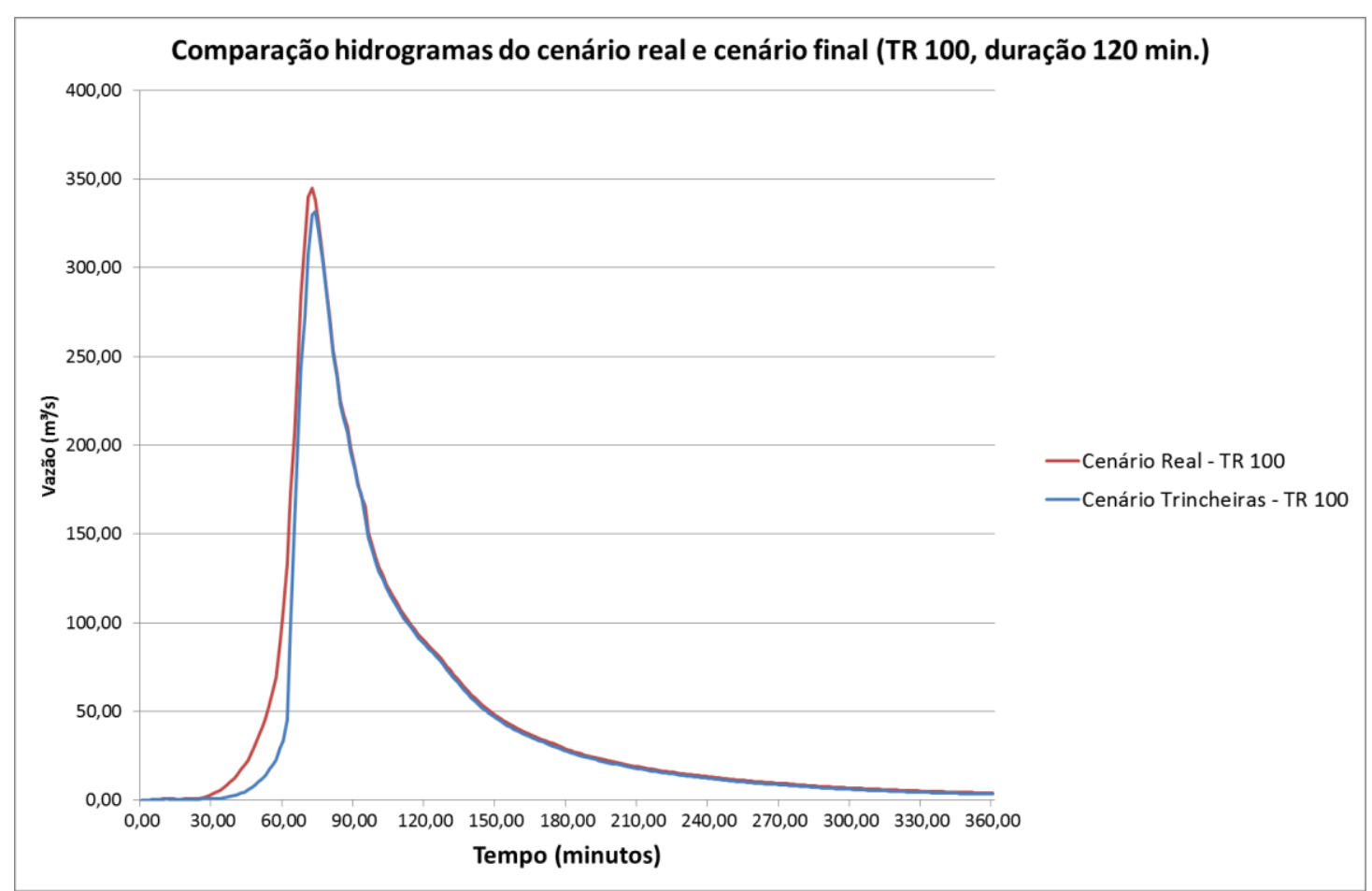

Figura 51 - Comparação entre hidrogramas do cenário real e do cenário de trincheiras de infiltração para TR 100 anos

Nos dois hidrogramas apresentados, nota-se que o cenário de trincheiras promoveu uma redução na vazão de pico e volume dos hidrogramas. Como ponto mais interessante a ser destacado está a maneira como as trincheiras atuam no controle de escoamento superficial. Pode-se observar nos gráficos que o hidrograma do cenário de trincheiras permanece menor que o hidrograma real durante todo 0 tempo analisado. Isto indica que as trincheiras de infiltração não possuem efeito de detenção das águas pluviais, ou seja, a água não fica armazenada temporariamente para depois retornar ao sistema de drenagem - se isto ocorresse, as vazões da curva descendente do hidrograma das trincheiras seriam superiores às vazões da mesma curva no hidrograma real. Assim, constata-se que o modelo representa 0 funcionamento das trincheiras de maneira coerente representando, portanto, modelos de infiltração total, conforme foram projetadas. Neste tipo de trincheira, a água de escoamento adentra os dispositivos até que se atinja a capacidade de armazenamento dos mesmos e, depois de saturado, o escoamento que chega às trincheiras não adentra e segue escoando superficialmente. Assim, pela absorção ocorrer apenas no início do escoamento, ocorre atraso no início da curva de ascensão do hidrograma, diminuição da vazão de pico e do volume do hidrograma, mas o 
formato da curva descendente permanece praticamente inalterado (CHAHAR; GRAILLOT; GAUR, 2012)

\subsubsection{Microreservatórios individuais}

Os resultados de redução de vazão, tempo de pico e volume dos hidrogramas gerados com o cenário de microreservatórios em relação ao cenário real são apresentados na Tabela 39.

Tabela 40 - Comparação entre hidrogramas do cenário microreservatórios em relação ao cenário real

\begin{tabular}{ccccc}
$\begin{array}{c}\text { Tempo de } \\
\text { retorno }\end{array}$ & $\begin{array}{c}\text { Redução vazão } \\
\text { de pico (\%) }\end{array}$ & $\begin{array}{c}\text { Redução tempo } \\
\text { de pico (\%) }\end{array}$ & $\begin{array}{c}\text { Redução } \\
\text { volume (\%) }\end{array}$ & $\begin{array}{c}\text { Redução de } \\
\text { volume }\left(\mathbf{m}^{3}\right)\end{array}$ \\
\hline $\mathbf{2}$ & 1,96 & 0,00 & 2,55 & $7.733,70$ \\
$\mathbf{5}$ & 1,02 & 0,00 & 1,95 & $7.792,20$ \\
$\mathbf{1 0}$ & 1,69 & $-4,17$ & 1,53 & $7.680,60$ \\
$\mathbf{5 0}$ & 0,08 & 0,00 & 0,93 & $7.868,70$ \\
$\mathbf{1 0 0}$ & $-0,03$ & 0,00 & 0,73 & $7.686,90$ \\
\hline
\end{tabular}

Os microreservatórios individuais tiveram efeito bastante discreto no controle da vazão de pico e na redução do volume de escoamento. Assim como nas trincheiras de infiltração, a redução do volume e o volume retido pelas estruturas foi praticamente o mesmo para todos os casos, o que indica que estes utilizam sua capacidade máxima de retenção em todos os casos e que, uma vez cheios, param de contribuir no controle do escoamento. Para a região do mercado municipal ocorreu o mesmo, reduções discretas na vazão de pico e volumes retidos praticamente iguais, conforme apresentado na Tabela 40.

Tabela 41 - Comparação de valores de referência entre hidrogramas do cenário de microreservatórios e cenário real para a região do mercado municipal

\begin{tabular}{cccc}
\hline $\begin{array}{c}\text { Tempo de } \\
\text { retorno }\end{array}$ & $\begin{array}{c}\text { Redução vazão } \\
\text { de pico (\%) }\end{array}$ & $\begin{array}{c}\text { Redução } \\
\text { volume (\%) }\end{array}$ & $\begin{array}{c}\text { Redução de } \\
\text { volume }\left(\mathbf{m}^{3}\right)\end{array}$ \\
\hline $\mathbf{2}$ & 0,77 & 2,55 & $6.203,70$ \\
$\mathbf{1 0}$ & 0,36 & 1,52 & $6.148,80$ \\
$\mathbf{5 0}$ & $-0,03$ & 0,89 & $6.181,20$ \\
\hline
\end{tabular}

Aparentemente, a capacidade de interferir no hidrograma das bacias foi limitada pela quantidade e volume útil dos dispositivos projetados para este cenário. Além 
disso, vale lembrar que as simulações ocorreram com os reservatórios vazios, estando toda a capacidade de armazenamento dos dispositivos disponível para uso durante a chuva. Em casos de precipitações com pouco intervalo entre eventos, a eficiência dos dispositivos diminui significativamente, podendo ser nula caso estejam com os reservatórios cheios. Tanto Dalmodaram et al. (2010) quanto Aad, Suidan e Shuster (2010) afirmam que é fundamental que se dimensione apropriadamente os tamanhos dos reservatórios para que os dispositivos surtam efeito no combate ao escoamento superficial.

Se os reservatórios tiverem a função somente de combate a inundações, recomenda-se a instalação de reservatórios individuais de detenção (com descarregadores) nas edificações (AAD; SUIDAN; SHUSTER, 2010). Neste caso, os microreservatórios individuais podem ser dispositivos eficientes no controle de escoamento se forem dimensionados apropriadamente. Tassi e Villanueva (2004), analisando a eficiência de microreservatórios com descarregadores de fundo em uma bacia hidrográfica para tempos de retorno de 5 e 10 anos, afirmaram que estes dispositivos podem ser realmente eficientes no combate a vazões de pico após utilizarem microreservatórios de detenção de $4,2 \mathrm{~m}^{2} \mathrm{em} 768$ lotes com um reservatório em cada.

Na Tabela 41 são apresentados os valores de vazão de pico para o cenário de microreservatórios individuais.

Tabela 42 - Valores de vazão de pico $\left(\mathrm{m}^{3} / \mathrm{s}\right)$ para o exutório da bacia e para o a região do mercado para precipitações de 120 minutos de duração no cenário de microreservatórios

\begin{tabular}{cccccc}
\hline Tempo de retorno & $\mathbf{2}$ & $\mathbf{5}$ & $\mathbf{1 0}$ & $\mathbf{5 0}$ & $\mathbf{1 0 0}$ \\
\hline Exutório & 101,11 & 135,00 & 165,29 & 272,17 & 345,14 \\
\hline Mercado & 82,83 & 110,29 & 140,01 & 231,07 & 286,18 \\
\hline
\end{tabular}

Apesar da discreta redução na vazão de pico, deve-se considerar os outros efeitos do uso do dispositivo, como a redução do volume escoado, o que pode trazer benefícios se utilizado em conjunto com outros dispositivos, principalmente os de detenção. Além disso, o armazenamento da água de chuva traz inúmeros benefícios aos usurários, reduzindo o consumo de água da rede pública e reduzindo custos ao utilizar esta água para fins não potáveis (GUNDERSON et al., 2011). Wright et al. (2016), diante da simulação de diversas técnicas compensatórias (todas também analisadas por este trabalho), obtiveram os resultados menos expressivos com os 
microreservatórios, todos com valores abaixo de $5 \%$ de redução de escoamento superficial em uma média anual. Entretanto, os autores recomendam seriamente sua utilização, já que são os dispositivos mais baratas e de fácil instalação dentre todos aqueles analisados por eles, além de não possuírem quaisquer restrições quanto à adequabilidade de áreas desenvolvidas quanto à sua implantação.

Além disso, cabe aqui comentar que, embora os mapas de adequabilidade à implantação de telhados verdes e cisternas na área de estudos sejam iguais, se analisados os locais de instalação caso a caso, as cisternas certamente seriam adequadas em mais casos, uma vez que não dependem de declividade ou estrutura de telhados para aprovação da instalação.

A fim de se aprofundar a discussão acerca dos microreservatórios individuais, foi criado um cenário alternativo deste dispositivo. Neste cenário alternativo, baseado no volume total de escoamento por telhado para o tempo de retorno de 2 anos, $4,36 \mathrm{~m}^{3}$, aumentou-se a capacidade dos microreservatórios justamente para este valor, $4,34 \mathrm{~m}^{3}$, mantendo-se todas as outras características do cenário tais quais utilizadas no cenário de microreservatórios. Apesar do novo volume ser adequado para este tipo de dispositivo, não á fácil a construção de reservatórios desta magnitude em edificações já construídas, principalmente em $25 \%$ dos telhados de uma área urbana, confirme considerado no cenário alternativo de microreservatórios. Assim, este cenário alternativo tem relevância apenas na investigação do potencial de controle de escoamento destes dispositivos em escala de bacias hidrográficas e não representa, necessariamente, um cenário plausível.

Os resultados do cenário alternativo de microreservatórios são apresentados na Tabela 43.

Tabela 43 - Reduções percentuais de vazão de pico dos cenários alternativos de microreservatórios em relação ao cenário real

\begin{tabular}{|cccccc|}
\hline \multicolumn{7}{|c|}{ REDUÇõES DE VAZÃO DE PICO } \\
\hline Tempo de retorno & 2 & 5 & 10 & 50 & 100 \\
\hline $\begin{array}{l}\text { Cenário alternativo } \\
\text { microreservatórios }\end{array}$ & $13,85 \%$ & $13,71 \%$ & $12,15 \%$ & $11,12 \%$ & $6,37 \%$ \\
\hline
\end{tabular}

Os resultados para reservatórios de $4,34 \mathrm{~m}^{3}$ foram consideravelmente melhores que os resultados com reservatórios de $1 \mathrm{~m}^{3}$ utilizados no cenário de microreservatórios, chegando a valores bastante satisfatórios e consistentes para precipitações entre 2 e 50 anos. Para a tormenta de 100 anos, apesar da baixa 
redução de vazão de pico, a redução obtida pode ainda ser considerada relevante. Assim, apesar de não comporem o cenário final e pelos resultados insatisfatórios para o cenário com $1 \mathrm{~m}^{3}$ de reservação, os microreservatórios podem ser considerados dispositivos eficientes no controle de escoamento superficial e apresentam grande potencial de mitigação dos impactos da urbanização em bacias hidrográficas com ocupação densa, principalmente pela facilidade de instalação e pela grande facilidade de se obter áreas aptas à sua instalação em ambientes urbanos.

\subsubsection{Cenário final}

Inicialmente, como comentários gerais sobre a metodologia para representação das técnicas compensatórias trabalhando em conjunto, os resultados obtidos nas simulações mostram que o desmembramento das sub-bacias hidrográficas permite uma maior flexibilidade na maneira como se conduz o fluxo de água na bacia, podendo representar as técnicas compensatórias existentes no modelo de maneira paralela ou linear, além da utilização simultânea de dispositivos de detenção centralizados. Em comparação com a representação clássica de bacias hidrográficas no modelo SWMM utilizadas no cenário real (bacias representadas por uma única parcela), os hidrogramas produzidos após desmembramento foram considerados coerentes quanto aos volumes, vazões de pico, formato e duração. Desta maneira, a metodologia apresentada para a simulação de funcionamento em conjunto de diversas técnicas compensatórias foi considerada válida e eficiente. Da maneira como foi formulada, a metodologia de desmembramento de sub-bacias pode ser replicada em diferentes casos e situações de simulações hidrológicas de técnicas compensatórias, e é limitada apenas pelos tipos de controles LID existentes no modelo SWMM, os quais representam apenas uma parcela dos dispositivos de compensação hidrológica utilizados em drenagem urbana sustentável.

Com relação à simulação hidrológica, os resultados da comparação dos valores de referência do cenário final - foi composto pelas bacias de detenção, telhados verdes pavimentos permeáveis e trincheiras de infiltração — com os hidrogramas do cenário real são apresentados na Tabela 42. 
Tabela 44 - Comparação entre hidrogramas do cenário final em relação ao cenário real

\begin{tabular}{ccccc}
$\begin{array}{c}\text { Tempo de } \\
\text { retorno }\end{array}$ & $\begin{array}{c}\text { Redução vazão } \\
\text { de pico (\%) }\end{array}$ & $\begin{array}{c}\text { Redução tempo } \\
\text { de pico (\%) }\end{array}$ & $\begin{array}{c}\text { Redução } \\
\text { volume (\%) }\end{array}$ & $\begin{array}{c}\text { Redução de } \\
\text { volume }\left(\mathbf{m}^{\mathbf{3}}\right)\end{array}$ \\
\hline $\mathbf{2}$ & 59,00 & $-12,00$ & 46,37 & $140.372,10$ \\
$\mathbf{5}$ & 48,10 & $-8,16$ & 39,54 & $158.391,90$ \\
$\mathbf{1 0}$ & 40,70 & $-8,33$ & 34,52 & $173.162,70$ \\
$\mathbf{5 0}$ & 27,49 & $-4,17$ & 28,96 & $243.831,60$ \\
$\mathbf{1 0 0}$ & 25,66 & $-4,17$ & 26,45 & $277.337,70$ \\
\hline
\end{tabular}

Para a região do mercado municipal, os resultados estão na Tabela 43.

Tabela 45 - Comparação de valores de referência entre hidrogramas do cenário final e cenário real para a região do mercado municipal

\begin{tabular}{cccc}
$\begin{array}{c}\text { Tempo de } \\
\text { retorno }\end{array}$ & $\begin{array}{c}\text { Redução vazão } \\
\text { de pico (\%) }\end{array}$ & $\begin{array}{c}\text { Redução } \\
\text { volume (\%) }\end{array}$ & $\begin{array}{c}\text { Redução de } \\
\text { volume }\left(\mathbf{m}^{3}\right)\end{array}$ \\
\hline $\mathbf{2}$ & 58,26 & 44,78 & $108.893,70$ \\
$\mathbf{1 0}$ & 42,32 & 32,87 & $133.034,40$ \\
$\mathbf{5 0}$ & 28,57 & 27,82 & $192.312,00$ \\
\hline
\end{tabular}

Analisando-se o valor da vazão de pico para todos os tempos de retorno, notase que os valores do cenário final são realmente muito inferiores aos calculados para o cenário real. Para uma breve comparação, cita-se que o valor de vazão de pico do tempo de retorno de 100 anos para o cenário final, $256,51 \mathrm{~m} / \mathrm{s}$, é inferior ao valor de vazão de pico para o tempo de retorno de 50 anos no cenário real, $272,39 \mathrm{~m}^{3} / \mathrm{s}$. $\mathrm{O}$ restante dos valores de vazão de pico pode ser conferido na Tabela 44.

Tabela 46 - Valores de vazão de pico $\left(\mathrm{m}^{3} / \mathrm{s}\right)$ para o exutório da bacia e para o a região do mercado para precipitações de 120 minutos de duração no cenário Final

\begin{tabular}{cccccc}
\hline Tempo de retorno & $\mathbf{2}$ & $\mathbf{5}$ & $\mathbf{1 0}$ & $\mathbf{5 0}$ & $\mathbf{1 0 0}$ \\
\hline Exutório & 42,28 & 70,79 & 99,70 & 197,52 & 256,51 \\
Mercado & 34,84 & 57,41 & 81,04 & 165,01 & 217,69 \\
\hline
\end{tabular}

Para todos os casos analisados, os resultados do cenário final foram bastante positivos. Entretanto, o efeito de controle de escoamento obtido pelo funcionamento em conjunto das técnicas compensatórias foi inferior às somas dos efeitos individuais dos dispositivos. Vale lembrar que, pelo fato de trincheiras e pavimentos serem instalados no mesmo espaço, os pavimentos permeáveis foram aplicados em áreas menores neste cenário, mais especificamente com 19,06 hectares (14,83\%) a menos 
de área. No exutório da bacia, houve uma considerável queda nas reduções promovidas pelos dispositivos à medida que aumentaram os eventos chuvosos, caindo de 59,00\% de redução de vazão de pico para TR 2 anos para 25,66\% de redução para TR 100 anos. Apesar disso, a redução obtida de volume e vazão de pico ainda é bastante significativa. As diferenças de volume dos hidrogramas aumentaram à medida que as precipitações aumentaram, indicando que nos eventos menores a capacidade de detenção dos dispositivos não foi superada.

Para a região do mercado municipal, os resultados obtidos também foram bastante positivos em todos os casos, com expressivas quedas de vazão de pico e volume de hidrogramas para todos os tempos de retorno analisados.

Para melhor entendimento do efeito das medidas compensatórias na resposta da bacia hidrográfica, são comparados a seguir os hidrogramas do cenário real e cenário final para tempos de retorno de 2, 10 e 100 anos na Figura 52, Figura 53, Figura 54, respectivamente.

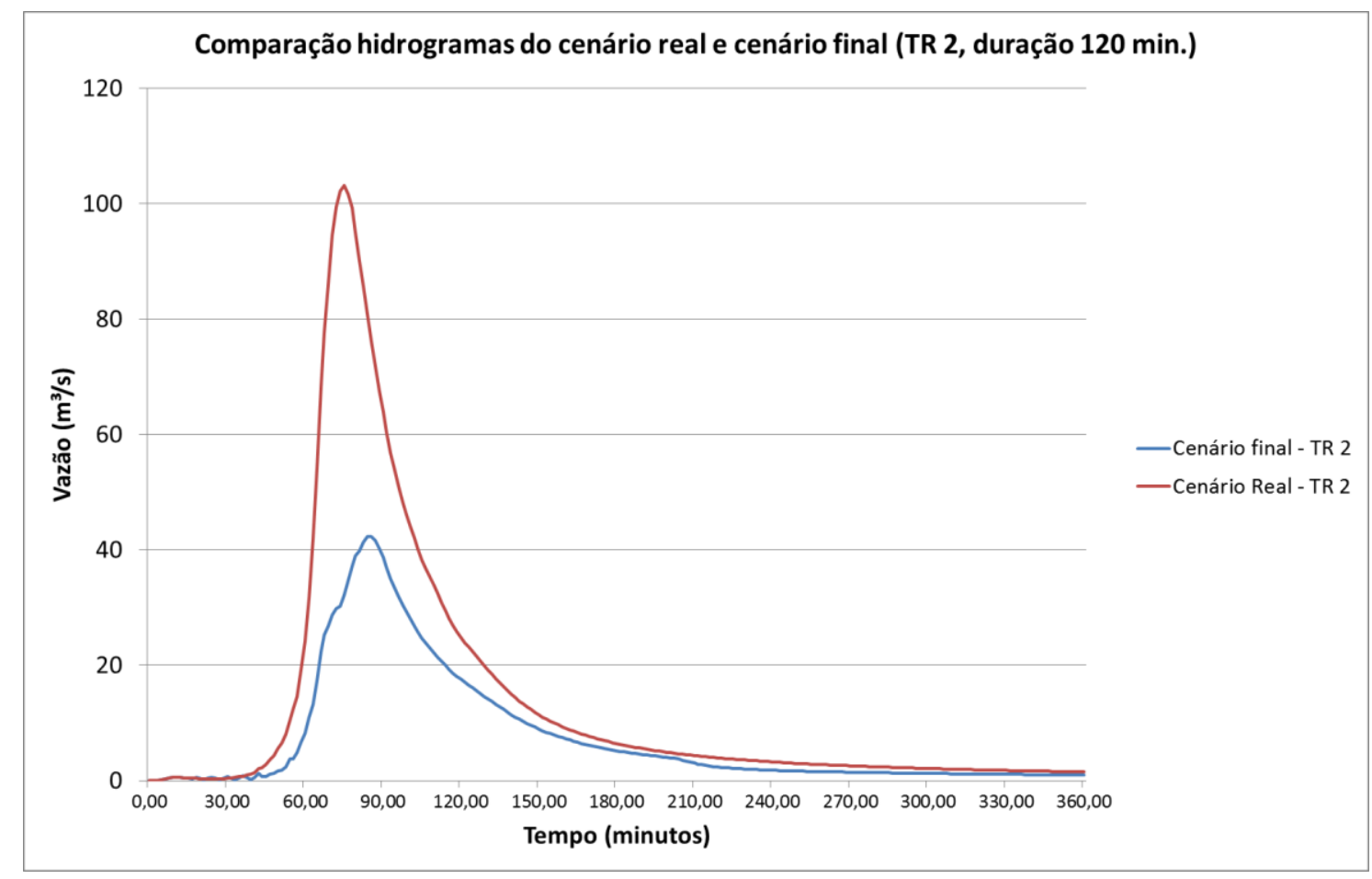

Figura 52 - Comparação de hidrogramas entre cenário real e cenário final para TR 2 anos 


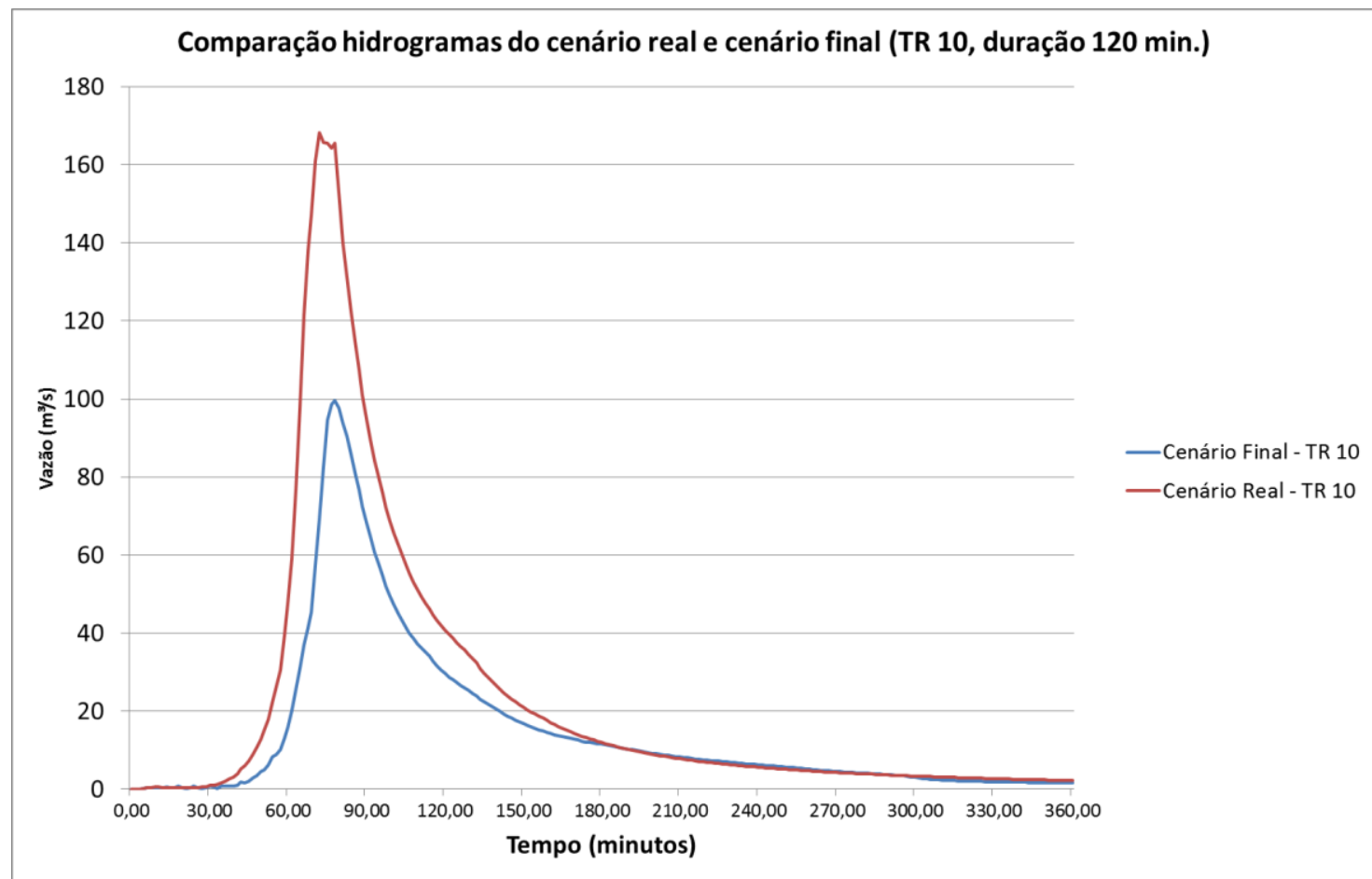

Figura 53 - Comparação de hidrogramas entre cenário real e cenário final para TR 10 anos

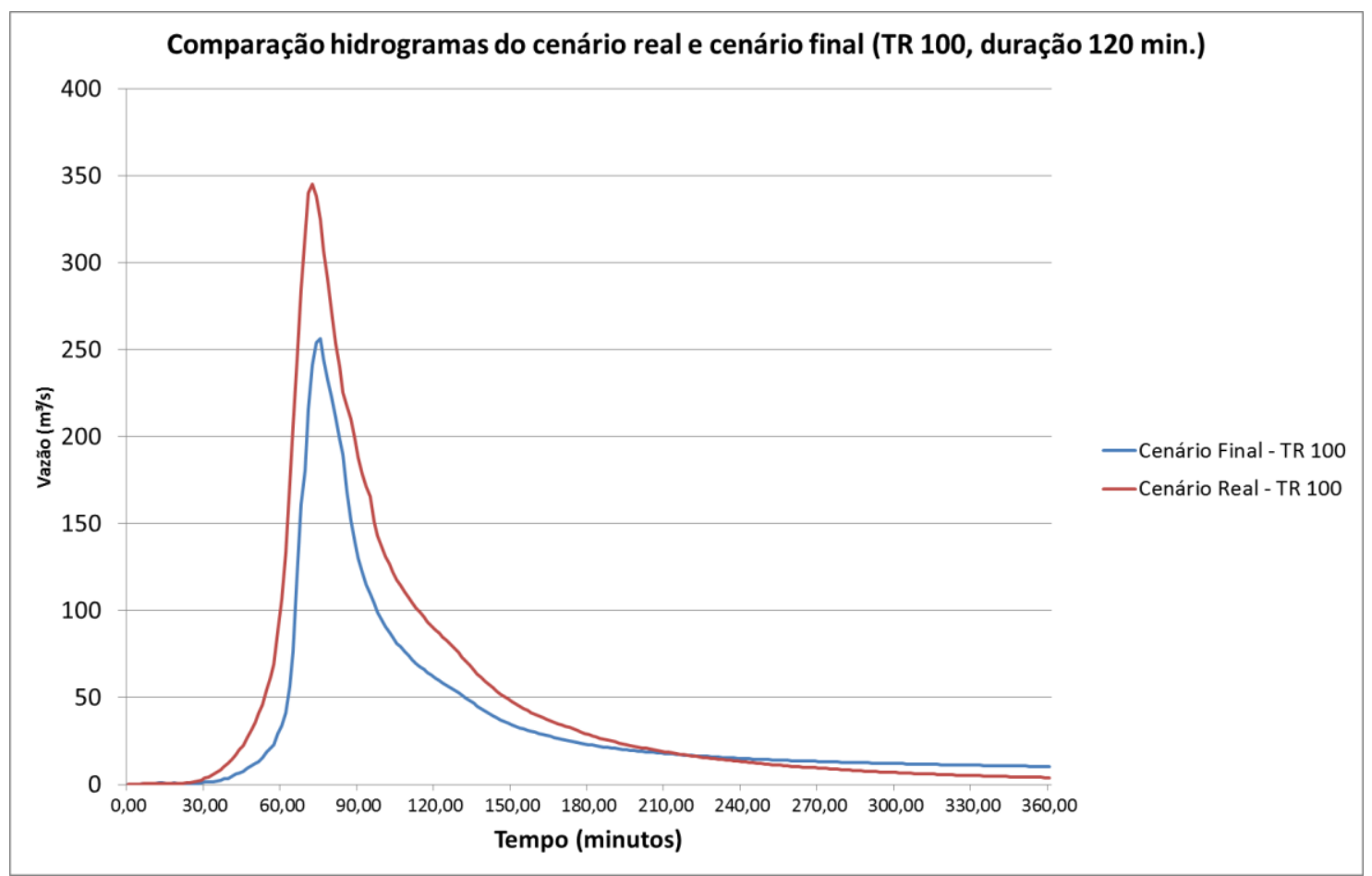

Figura 54 - Comparação de hidrogramas entre cenário real e cenário final para TR 100 anos

Nos três casos apresentados houve uma considerável redução no pico da vazão e nos volumes dos hidrogramas. Porém, para nenhum dos casos se nota atraso significativo no instante do pico. Desta forma, ao menos para as simulações realizadas, pode-se concluir que as condições pré-desenvolvimento de tempo de 
Avaliação do potencial de aplicação de técnicas compensatórias em áreas urbanas consolidadas

concentração da bacia não podem ser recuperadas com a implantação das técnicas compensatórias. Outros pesquisadores como Damodaram et al. (2010) e Miguez et al. (2009), simulando o uso de técnicas compensatórias combinadas em áreas já urbanizadas, também não detectaram alterações no tempo de pico das bacias, mesmo quando utilizadas técnicas na fonte associadas a bacias de detenção.

Ainda em relação às figuras 51, 52 e 53, para o tempo de retorno de 2 anos, praticamente todo o volume retido pelos dispositivos compensatórios durante o evento chuvoso é absorvido, seja por detenção ou infiltração, e não retorna ao sistema de drenagem, conforme visto no hidrograma, o que também acontece para o tempo de retorno de 10 anos. Entretanto, para o evento de 100 anos, além de uma redução menor na magnitude do pico de vazão, é possível notar que parte do volume retido pelas LID retorna para o sistema de drenagem ao longo da curva de recessão do hidrograma e, por volta do instante 220 minutos, a vazão do hidrograma do cenário final torna-se maior que a vazão do cenário real, permanecendo assim até o fim dos hidrogramas.

Analisando-se o desempenho individual de cada dispositivo na simulação, foi averiguado que para telhados verdes, pavimentos permeáveis e trincheiras de infiltração os valores de entrada e saída do dispositivo foram praticamente semelhantes aos valores dos cenários individuais. Desta forma, nota-se que houve pouca variação na maneira como os dispositivos funcionaram, mesmo trabalhando em conjunto. Miguez et al. (2009) afirmam que, embora o resultado de várias técnicas compensatórias funcionando em conjunto possa ser a soma dos efeitos individuais, isto depende da disposição espacial dos elementos ao longo da rede de drenagem e, muitas vezes, os resultados ficam abaixo do esperado. Um dos elementos mais importantes para a obtenção de resultados positivos é a disposição e escolha dos elementos que compõem o sistema, uma vez que os efeitos dos dispositivos devem se complementar, não concorrer. Neste sentido, algumas observações devem ser feitas a respeito da disposição utilizada neste cenário final. Para facilitar o entendimento, a Figura 55 mostra uma representação do percurso da água ao longo do sistema de drenagem e da disposição espacial das técnicas compensatórias no sistema de drenagem. Todavia, faz se a ressalva que, embora a configuração da rede permita que as bacias de detenção recebam água efluente de sub-bacias que possuam técnicas compensatórias, isto praticamente não ocorreu no cenário final, uma vez que os reservatórios não recebem água proveniente de áreas urbanas. 


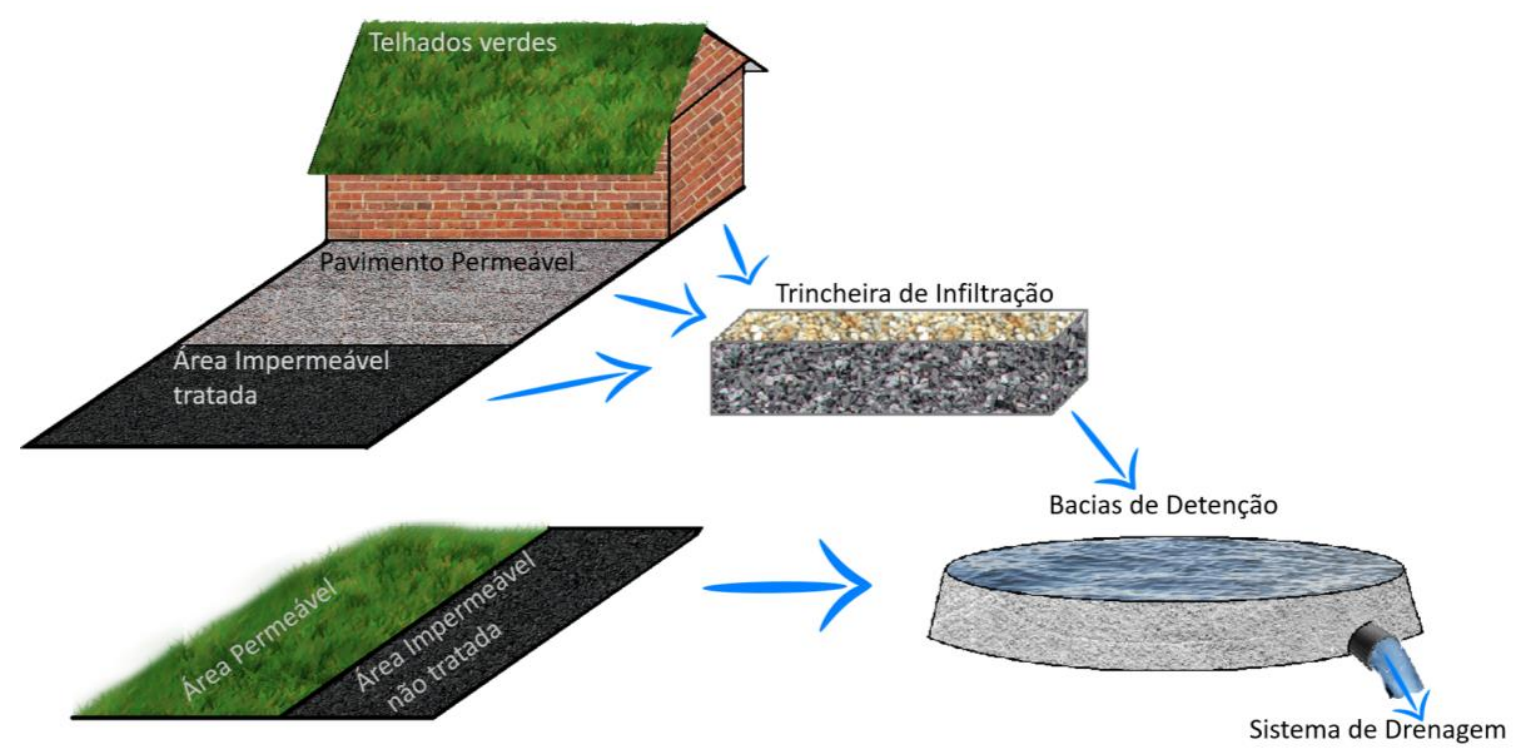

Figura 55 - Representação da disposição das técnicas compensatórias e do percurso do escoamento no cenário final

Na montagem final, manteve-se a condição imposta pelo modelo de que a água efluente de áreas permeáveis não recebe tratamento por controles LID que não as bacias de detenção. Assim, as áreas contempladas com técnicas compensatórias ficaram agrupadas em uma parcela da sub-bacia. Nesta parcela, a área total é dada pela área impermeável tratada calculada no cenário de trincheiras de infiltração, dentro da qual estão incluídas as áreas ocupadas por telhados verdes e por pavimentos permeáveis. Os dois dispositivos que trabalham paralelamente, pavimento permeável e telhados verdes, tratam apenas a água que incide sobre eles, enviando às trincheiras de infiltração somente o escoamento excedente. $\mathrm{Na}$ outra parcela da sub-bacia, a chamada parcela livre, estão a área permeável da bacia e a área impermeável que não recebe tratamento algum por controles LID. Esta parcela, envia a água diretamente para o sistema de drenagem. Quanto às bacias de detenção, para que o escoamento das sub-bacias receba tratamento, a mesma deve estar à montante de um dispositivo de detenção, caso contrário esta não recebe tratamento algum.

Esta análise diminui suspeitas sobre a possibilidade de conflito entre pavimentos permeáveis e trincheiras de infiltração (durante a modelagem), uma vez que, na prática, ambas são dispostas linearmente e, durante a montagem do cenário, foi permitida a existência dos dois dispositivos em um mesmo trecho de rua - faz-se aqui a ressalva quanto à possibilidade de conflitos técnicos de instalação de ambos, 
lado a lado, já que este trabalho não faz análise de tal natureza. Cabe também o comentário, conforme já citado anteriormente, de que foram priorizados os pavimentos permeáveis e as trincheiras de infiltração frente aos jardins de chuva (principalmente pela condição irregular dos passeios e da maior disponibilidade de espaço nas ruas para a instalação das trincheiras), o que também diminui a ocorrência de diferentes técnicas compensatórias em um único local, no caso as ruas e seus passeios.

Para se facilitar uma análise de como o comportamento individual de cada dispositivo afeta o resultado do cenário final, apresenta-se na Figura 56 as reduções de vazão de pico obtidas em cada cenário individual e no cenário final.

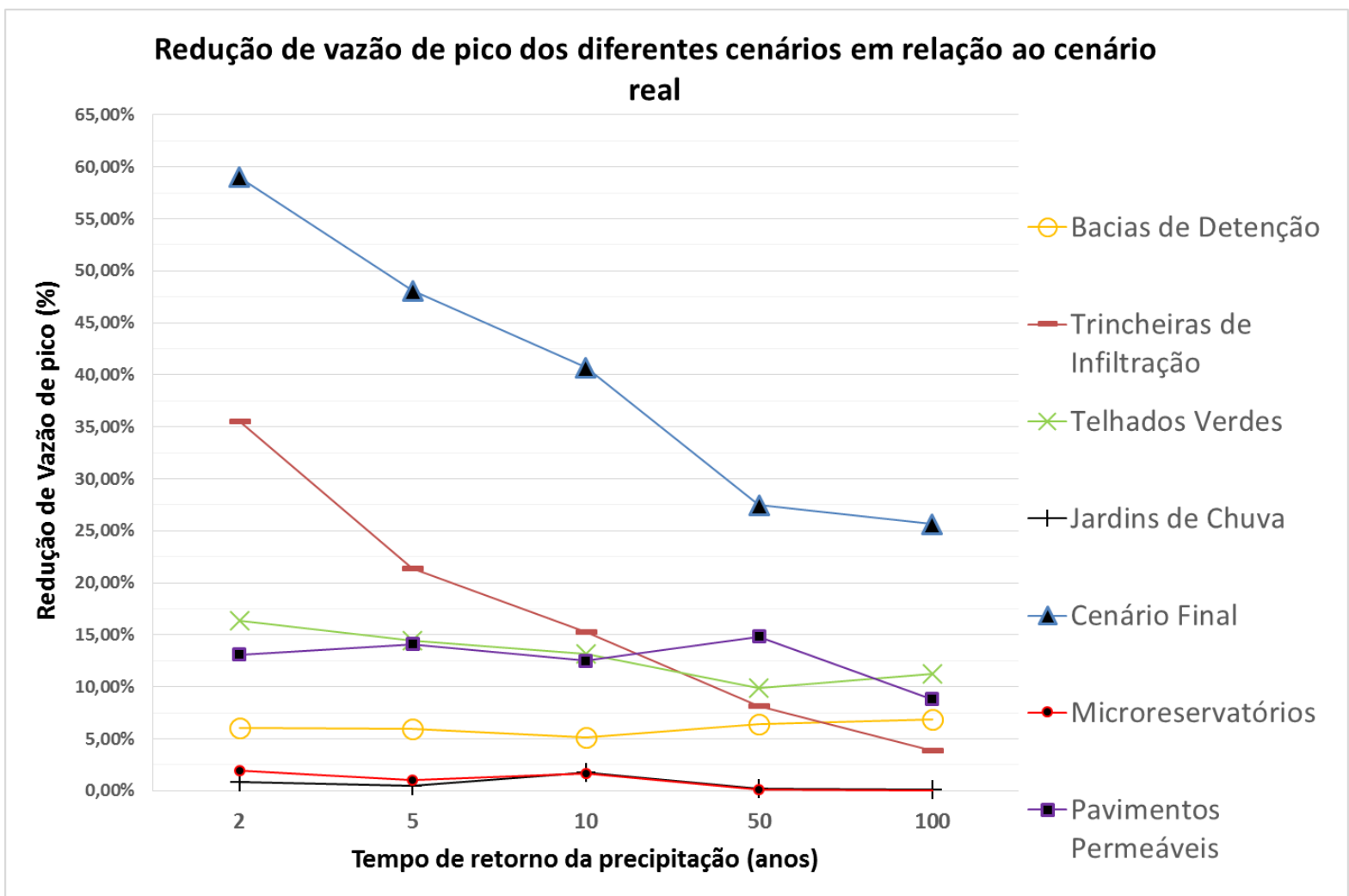

Figura 56 - Comparação das reduções de vazão de pico de cada um dos cenários analisados

Em uma breve análise e recapitulação sobre o desempenho de cada um para as diferentes precipitações, nota-se que os microreservatórios e os jardins de chuva realmente foram ineficientes para todos os casos. As bacias de detenção tiveram eficiência discreta, porém consistente, inclusive com melhores resultados de redução para maiores precipitações. Os telhados verdes e os pavimentos permeáveis tiveram bons desempenhos em redução com resultados também consistentes e, por fim, as 
trincheiras de infiltração tiveram excelente desempenho para chuvas menos intensas e desempenho ruim para aquelas mais raras.

Com relação às reduções do cenário final, nota-se que sua curva de reduções tem gradiente análogo à curva do cenário de trincheiras de infiltração, o que dá a entender que as trincheiras foram os responsáveis por grande parte do bom desempenho do cenário final para precipitações menores. O decréscimo da redução de vazão do cenário final assim que as trincheiras reduzem seu desempenho individual também reforças este entendimento. Entretanto, a análise conjunta de todos os cenários mostra também a importância dos outros dispositivos no processo. As bacias de detenção, os pavimentos permeáveis e os telhados verdes, apesar de não chegarem a grandes valores de redução de vazão de pico para nenhum dos casos, apresentam um desempenho mais consistente, não sofrendo quedas de desempenho significativas quando as precipitações foram mais intensas. Desta maneira, quando utilizados em cenários com múltiplas técnicas compensatórias, estes dispositivos garantem um desempenho mais regular do sistema de drenagem e não permitem que quedas acentuadas de desempenho de determinados dispositivos comprometam o sistema de drenagem como um todo. Isto pode ser visto nas precipitações com tempos de retorno de 50 e 100 anos, quando a curva de redução de vazão de pico do cenário final não sofre redução de desempenho tão acentuada quanto as trincheiras de infiltração, o que pode ser explicado pelos valores de redução apresentados pelos outros dispositivos já mencionados.

Damodaram et al. (2010) afirmam que uma das grandes vantagens de se combinar diversas técnicas compensatórias em um mesmo local é que se extrai o melhor de cada uma, tendo bons resultados tanto para precipitações intensas como para precipitações de alta frequência, geralmente ignoradas quando do dimensionamento de grandes estruturas. No presente trabalho, por se tratar do uso de técnicas compensatórias em um ambiente já urbanizado, dificilmente é possível se trabalhar com a combinação das técnicas desejadas em um arranjo espacial ótimo ao controle de escoamento. Perez-Pedini, Limbrunner e Vogel (2005) afirmam que a localização ótima de dispositivos na bacia hidrográfica é uma função complexa entre a rede de drenagem da bacia, tempos de percurso, distância entre dispositivo e o canal principal e uso e ocupação do solo. 
No cenário final, a eficiência das técnicas compensatórias no combate às vazões de pico de grandes eventos não foi a mesma apresentada nas precipitações menores, o que poderia ser diferente se houvesse maior flexibilidade na escolha da localização das técnicas compensatórias.

Os resultados apresentados deixam em evidência a dificuldade de se trabalhar com técnicas compensatórias em áreas urbanizadas, uma vez que a amortização dos hidrogramas nas áreas críticas da bacia poderia ser maior no caso da existência de bacias de detenção estrategicamente localizadas para combate de inundações. Entretanto, pelo posicionamento dos cinco reservatórios de detenção do PDDUAS, com exceção do reservatório LA-2, as bacias de detenção não recebem água proveniente de áreas com técnicas compensatórias e nem de áreas densamente urbanizadas.

Visto que as técnicas compensatórias simuladas não contribuíram para reduzir os hidrogramas afluentes aos reservatórios de detenção e que estes foram as técnicas menos eficientes dentre os dispositivos que compuseram o cenário final, foi feita uma análise do desempenho individual de cada reservatório para que se investigasse os percentuais de volume útil de cada reservatório utilizados durante as precipitações. Surpreendentemente, notou-se que estes estavam sendo significativamente subutilizados. Na Tabela 45 são apresentados os percentuais do volume útil de cada bacia de detenção utilizada durante as precipitações simuladas.

Tabela 47 - Percentual do volume útil das bacias de detenção utilizadas durante as precipitações

\begin{tabular}{cccccc} 
TR & $\mathbf{2}$ anos & $\mathbf{5}$ anos & $\mathbf{1 0}$ anos & $\mathbf{5 0}$ anos & $\mathbf{1 0 0}$ anos \\
G-1 & $0,0 \%$ & $0,0 \%$ & $0,0 \%$ & $4,0 \%$ & $9,0 \%$ \\
G-2 & $0,0 \%$ & $0,0 \%$ & $1,0 \%$ & $17,0 \%$ & $35,0 \%$ \\
S-1 & $3,0 \%$ & $5,0 \%$ & $9,0 \%$ & $29,0 \%$ & $45,0 \%$ \\
LA-2 & $7,0 \%$ & $11,0 \%$ & $15,0 \%$ & $27,0 \%$ & $29,0 \%$ \\
LA-1 & $28,0 \%$ & $44,0 \%$ & $61,0 \%$ & $100,0 \%$ & $100,0 \%$ \\
\hline
\end{tabular}

Conforme já mencionado, o posicionamento dos reservatórios de detenção dá a entender que o local de sua instalação foi determinado exclusivamente pela disponibilidade de espaço, uma vez que ficam posicionados nas áreas ainda não urbanizada mais à montante da bacia, praticamente não recebendo água proveniente da malha urbana. O resultado deste posicionamento reflete nos resultados apresentados na Tabela 47, nos quais se observa que, com exceção do reservatório 
LA-1, todos os reservatórios são exigidos em menos de $50 \%$ de sua capacidade de detenção. No caso do reservatório G-1, mesmo para tempo de retorno de 100 anos, este é exigido em menos de $10 \%$ de sua capacidade de detenção total. Desta maneira, levanta-se a dúvida quanto à necessidade da construção de todos os reservatórios planejados ou se é mesmo necessário que os reservatórios tenham o volume útil previsto.

Embora Andoh e Declerck (1999) afirmem que bacias de detenção são apropriadas a países em desenvolvimento, uma vez que o processo de expansão geralmente encontra-se em andamento, Zhen, Yu e Li (2004) afirmam que, devido ao enorme investimento que representam, é necessário se utilizar uma abordagem sistemática para o planejamento e dimensionamento de bacias de detenção a nível de bacia hidrográfica, o que pode levar dispositivos mais eficientes e economias bastante significativas.

Neste contexto, simulando o uso conjunto de técnicas na fonte aplicadas a ambientes já urbanizados juntamente com bacias de detenção, Damodaram et al. (2010) concluíram que a combinação de dispositivos extensivos e intensivos é bastante eficiente, uma vez que técnicas lineares e na fonte são mais eficientes em precipitações menores e técnicas centralizadas tem bons desempenhos em precipitações maiores, o que garante um razoável controle de escoamento para qualquer tamanho de evento.

Em complemento, diversos estudos avaliaram os efeitos da aplicação de controles LID em escalas locais. Nos estudos foram avaliadas trincheiras de infiltração (WILLIAMS \& WISE, 2006), jardins de chuva (BRANDER; OWEN; POTTER, 2004), cisternas (SAMPLE \& HEANEY, 2006; GILROY \& MCCUEN, 2009) e até mesmo a combinação de poços de infiltração, bacias de detenção, cisternas e valas vegetadas em escala de lote (XIAO; MCPHERSON; SIMPSON, 2003). Todos estes estudos concordam que as técnicas compensatórias na fonte e lineares são adequadas para controlar o escoamento superficial de eventos de até 5 anos de tempo de retorno. Entretanto, o desempenho das técnicas compensatórias frente a precipitações iguais ou maiores que 10 anos não pode ser comparado à eficiência de bacias de detenção de médio e grande porte (DAMODARAM, et al. 2010). Portanto, a associação de técnicas na fonte, lineares e centralizadas é essencial para que se possa mitigar os efeitos da urbanização em áreas já urbanizadas. Entretanto, pelos resultados obtidos 
no presente trabalho, entende-se que a implementação das bacias de detenção deva ocorrer posteriormente à implantação dos outros dispositivos compensatórios, uma vez que estes tiveram atuação mais incisiva no controle dos impactos hidrológicos da urbanização. 


\section{CONCLUSÕES}

O presente trabalho teve por objetivo avaliar o desempenho em conjunto de técnicas compensatórias aplicadas de maneira extensiva em uma bacia hidrográfica urbana densamente urbanizada através de modelagem hidrológica. A bacia hidrográfica escolhida como área de estudos foi a bacia hidrográfica do córrego do Gregório, na cidade de São Carlos, que possui parcelas rurais e parcelas urbanas de alta densidade de ocupação.

Foi feito um diagnóstico da área de estudos que revelou uma bacia hidrográfica bastante heterogênea, com sub-bacias entre 0 e 70\% de impermeabilização de superfícies. O processamento e classificação de imagens de satélite através de análise orientada a objetos se mostrou uma importante ferramenta para subsidiar estudos em hidrologia urbana. A partir dos resultados foi possível se obter dados importantes para a etapa de modelagem hidrológica como o Curve-Number (CN) e o grau de impermeabilização das sub-bacias.

Para atingir o objetivo principal do trabalho, desenvolveu-se uma metodologia que permitisse avaliar a superfície da bacia quanto à adequabilidade à implantação de diversas técnicas compensatórias e que, a partir disso, fosse feito o planejamento e quantificação dos dispositivos compensatórios sobre a área da bacia hidrográfica. A metodologia consistiu em um processo de álgebra de mapas em ambiente SIG, baseando-se sobretudo em critérios técnicos apresentados por diversos manuais de drenagem urbana sustentável. A metodologia desenvolvida foi considerada eficiente e, portanto, apropriada para um primeiro planejamento de implantação e quantificação de dispositivos compensatórios, e seu resultado foi de fundamental importância para a criação dos cenários hipotéticos utilizados na etapa de modelagem hidrológica do trabalho. Apesar de simples, a metodologia apresentada foi capaz de considerar a maioria dos critérios técnicos exigidos pelos manuais durante a discretização da área de estudos. Entretanto, apesar de apresentar os resultados de forma detalhada e individual (como, por exemplo, quais trechos de ruas podem receber pavimentos permeáveis) o método apresentado é apenas um planejamento preliminar e não dispensa uma análise mais detalhada dos locais de implantação, caso a caso, para se avaliar detalhadamente as condições de adequabilidade e implantação dos dispositivos compensatórios. 
A partir dos mapas de adequabilidade e de um pré-dimensionamento dos dispositivos compensatórios, foi possível quantificar técnicas compensatórias para a criação de cenários hipotéticos de implantação de dispositivos em escala de bacias.

Através de simulação hidrológica com o modelo SWMM, o desempenho de 8 cenários foi avaliado para diferentes precipitações. A avaliação consistiu na comparação do hidrogramas de 7 cenários hipotéticos ao hidrograma do cenário real para se quantificar redução da vazão de pico, retardamento de tempo de pico e redução do volume de hidrogramas de cheia da bacia hidrográfica, além de seus efeitos na magnitude e formato do hidrograma. Com exceção dos jardins de chuva e microreservatórios residenciais, todos os dispositivos analisados se mostraram eficientes no controle do escoamento. Além disso, o software SWMM mostrou-se adequado para a tarefa.

Com relação aos dispositivos avaliados nos cenários hipotéticos, as bacias de detenção apresentaram resultado individual positivos, sendo capazes de amortecer consideravelmente os hidrogramas locais. Entretanto, seu desempenho em nível de bacia hidrográfica foi discreto e considerado abaixo do esperado para cinco reservatórios de detenção em uma bacia deste porte. Por fazerem parte do PDDUAS da cidade de São Carlos, os reservatórios foram considerados na montagem do cenário final. Quanto ao posicionamento e dimensionamento dos reservatórios, concluiu-se que, por serem localizados muito à montante da bacia, são eficientes apenas localmente, sendo subutilizados em todas as precipitações analisadas e apresentando desempenho insatisfatório em nível de bacia hidrográfica.

Os pavimentos permeáveis, ocupando uma área de 7,93\% em relação à área total da bacia, tiveram um bom e constante desempenho para precipitações entre $2 \mathrm{e}$ 50 anos de tempo de retorno, apresentando leve queda de desempenho apenas para a precipitação de 100 anos. As taxas de redução de vazão variaram de $8,81 \%$ a $14,83 \%$ de redução de vazão de pico e $8,17 \%$ a $16,30 \%$ de redução de volume. Não foi detectado atraso no tempo de pico com o uso dos dispositivos. Os pavimentos permeáveis foram escolhidos para comporem o cenário final devido ao bom resultado e por desempenharem dupla função (arruamento e dispositivo compensatório), o que facilita sua aplicação em áreas já desenvolvidas.

Os jardins de chuva tiveram mau desempenho durante as simulações hidrológicas, apresentando reduções de vazão abaixo de 1\% para a maioria das precipitações e redução máxima de $3,68 \%$ do volume escoado na bacia. Uma vez que 
os efeitos dos jardins de chuva, em escala de bacia, foram insatisfatórios mesmo quando desempenho individual dos dispositivos foi razoável, o baixo impacto no hidrograma da bacia foi atribuído às dimensões e quantidade dos dispositivos, ambos insuficientes devido à dificuldade de se alocar estes dispositivos na área de estudos pela irregularidade de seus passeios públicos, com excesso de declividade e degraus. Além disso, por requisitarem área exclusiva para sua instalação e não desempenharem dupla função, seu uso é limitado em áreas já desenvolvidas. Desta maneira, estes dispositivos foram considerados ineficientes e não compuseram o cenário final.

Os telhados verdes, desde o mapa de adequabilidade, se mostraram apropriados para áreas já urbanizadas, uma vez que podem ser instalados em praticamente qualquer telhado. Além disso, ocupando $25 \%$ dos telhados identificados na baia hidrográfica e $5,15 \%$ de sua área total, os telhados verdes causaram reduções de $16,37 \%$ de vazão de pico para chuvas de 2 anos e 12,77\% para chuvas de 100 anos, o que indica uma capacidade significativa de controlar o escoamento gerado em pequenas e grandes precipitações. Entretanto, a análise da redução do volume dos hidrogramas evidenciou inconsistências nos resultados do modelo SWMM em relação à maneira como o software calcula balanço hídrico individual dos dispositivos. Todavia, a representação de sua atuação em escala de bacia hidrográfica mostrou-se coerente. Por fim, os telhados verdes foram considerados eficientes e compuseram o cenário final.

O cenário de trincheiras de infiltração lineares revelou que as trincheiras de infiltração são técnicas compensatórias com bom desempenho para precipitações pequenas - reduções de $35,50 \%$ na vazão de pico e de $32,48 \%$ no volume de hidrograma de cheias de precipitações de 2 anos - e mau desempenho em precipitações maiores - redução de 3,81\% na vazão de pico e de $9,57 \%$ no volume escoado de precipitações de 100 anos. Pela possibilidade de serem instaladas em pequenas áreas junto às sarjetas ou mesmo abaixo de pavimentos permeáveis, o que manteria a função original da área destinada ao estacionamento de carros, por exemplo, as trincheiras de infiltração mostram-se dispositivos promissores no controle do escoamento em áreas urbanas, principalmente se considerado que ocuparam apenas $0,79 \%$ da área total da bacia. Entretanto, pela grande variação de desempenho apresentado nas simulações, recomenda-se a implantação de 
trincheiras juntamente com outros dispositivos que possuam desempenho mais consistente, para que assim se controle também o escoamento de precipitações críticas. Por fim, as trincheiras de infiltração foram consideradas na composição do cenário final.

No cenário de microreservatórios individuais, considerou-se que $25 \%$ dos telhados identificados na bacia hidrográfica teriam seu escoamento interceptado por um reservatório de $1 \mathrm{~m}^{3}$ de volume. Os reservatórios tiveram desempenho discreto tanto na redução de vazão de pico como redução de volume. Aparentemente, o volume dos reservatórios ficou muito abaixo do necessário para causar impacto significativo nos hidrogramas das bacias hidrográficas. Apesar do mau desempenho, após breve discussão concluiu-se que a utilização destes dispositivos é importante para a bacia hidrográfica ao passo que, além de reduzir o volume escoado, ainda diminui a demanda da população sobre os mananciais de abastecimento público. Além do mais, o dispositivo pode ser facilmente adaptado à maioria das edificações existentes, sendo, portanto, importante na adaptação das cidades aos princípios de drenagem urbana sustentável. Apesar disso, os microreservatórios não foram considerados na criação do cenário final.

Na montagem do cenário final, foram consideradas as bacias de detenção, os pavimentos permeáveis, os telhados verdes e as trincheiras de infiltração. Para que fosse representada corretamente a disposição espacial de todas as técnicas compensatórias no modelo SWMM, foi necessário que se desenvolvesse uma nova metodologia para representação das sub-bacias hidrográficas de maneira desmembrada, o que exigiu que fossem recalculados praticamente todos os parâmetros hidrológicos da bacia do Gregório. Após a montagem do cenário final, foi feita a simulação hidrológica para eventos de 120 minutos com tempos de retorno de 2, 5, 10, 50 e 100 anos. Quanto ao tempo de concentração da bacia, concluiu-se que as condições pré-desenvolvimento não podem ser recuperadas com a implantação das técnicas compensatórias conforme projetadas. Com relação aos hidrogramas de cheia, para os eventos de precipitação de até 10 anos, a bacia hidrográfica apresentou significativa redução de vazão de pico - 59,00\%, 48,10\% e 40,70\% para eventos de 2, 5 e 10 anos, respectivamente - e de volumes de hidrogramas- reduções de $46,37 \%, 39,54 \%$ e $34,52 \%$ para 2, 5 e 10 anos. O impacto das técnicas compensatórias nos hidrogramas de 50 e 100 anos de tempo de retorno não foi tão profundo quanto foi para precipitações menores, mas, mesmo assim, puderam ser 
considerados bons, uma vez que o hidrogramas sofreram redução de vazão de pico de $27,49 \%$ e $25,66 \%$ (para 50 e 100 anos de tempo de retorno, respectivamente) se comparados aos hidrogramas do cenário real. Além disso, o volume foi reduzido em $28,96 \%$ e $26,45 \%$ para 50 e 100 anos. Desta forma, considerou-se que a adaptação de regiões já urbanizadas aos princípios da drenagem sustentável é possível e os resultados da aplicação das técnicas compensatórias gera bons resultados. Entretanto, a magnitude dos hidrogramas é ainda bastante crítica para as regiões mais afetadas pelas inundações, como trecho em frente ao mercado municipal de São Carlos. 
Avaliação do potencial de aplicação de técnicas compensatórias em áreas urbanas consolidadas 


\section{RECOMENDAÇõES}

O atual trabalho fez um levantamento das áreas aptas a receberem diferentes técnicas compensatórias para controle da produção de escoamento superficial direto. Pela extensão do trabalho e necessidade de cumprimento de prazos, não foi possível que se fizesse uma inspeção em campo para que se averiguasse se a qualidade dos materiais cartográficos que deram origem aos mapas de adequabilidade é suficientemente representativa para subsidiar planejamentos e tomada de decisões. Assim, recomenda-se que futuros trabalhos que utilizem metodologia semelhante façam inspeções em campo para tal finalidade a fim de se averiguar características como resolução espacial ou escala de materiais cartográficos ideais para esta atividade.

Neste trabalho não foram avaliadas diferentes intensidades de aplicação de uma mesma técnica compensatória, como por exemplo, telhados verdes aplicados a um quarto, metade e todos os telhados identificados na imagem de satélite. Verificações como essa podem gerar informações importantes a gestores e profissionais da área quanto aos resultados obtidos com diferentes graus de intervenção na bacia hidrográfica. Assim, recomenda-se que trabalhos futuros investiguem a relação entre grau de intervenção e seus impactos nos hidrogramas das bacias.

Recomenda-se que trabalhos futuros utilizem a mesma metodologia de alocação de técnicas compensatórias em bacias com diferentes características e, se possível, em bacias que possuam maior disponibilidade de espaço para a alocação de técnicas compensatórias de grande porte como bacias de detenção, retenção e infiltração.

Por fim, recomenda-se que futuros trabalhos estabeleçam vazões críticas de inundação e avaliem a viabilidade econômica da execução dos cenários e, se possível, compare com os inúmeros prejuízos causados por eventos de inundação urbana na cidade de São Carlos. 
Avaliação do potencial de aplicação de técnicas compensatórias em áreas urbanas consolidadas 


\section{REFERÊNCIAS BIBLIOGRÁFICAS}

AAD, M.P.A.; SUIDAN, T. M.; SHUSTER, W.D. Modeling Techniques of Best Management Practices: Rain Barrels and Rain Gardens Using EPA SWMM-5. Journal of Hydrologic Engineering, v. 15, n.6, 2010.

ABBOTT, C.L.; MATEOS, L.C. In-Situ Hydraulic Performance of a Permeable Pavement Sustainable Urban Drainage System. Journal of the Chartered Institution of Water and Environmental Management, v.17, n.3, 2003.

ABREU, F.G. Análise da influência da distribuição temporal das chuvas intensas e de cenários de uso e ocupação do solo na quantificação dos prejuízos econômicos diretos provocados pelas inundações urbanas. Dissertação (Mestrado) - Universidade de São Paulo, Escola de Engenharia de São Carlos. São Carlos, 2013.

ABUSTAN, I.; HAMZAH, M.O.; RASHID, M.A. Review of Permeable Pavement Systems in Malaysia Conditions. International Journal of Sustainable Development, v.4, n.2, 2012.

AHIABLAME, L.M.; ENGEL, B.A. CHAUBEY, I. Effectiveness of Low Impact Development Practices: Literature Review and Suggestions for Future Research. Water Air Soil Pollution, v.223, p.4253-4273, 2012.

ALMEIDA, R. M. Estudo de Modelo Hidrodinâmico Unidimensional Aplicado a um Trecho de Canal do Córrego do Gregório, em São Carlos, SP. Dissertação (Mestrado) - Universidade de São Paulo, Escola de Engenharia de São Carlos. São Carlos, 2013.

ALMEIDA NETO, P.; ESTEVES, R.L.; BORGES, A.C.; MENDIONDO, E.M. Análise dos componentes do balanço hídrico em uma bacia urbana experimental. VII Simpósio de Recursos Hídricos no Nordeste. Anais... , São Luis, 2004.

ALVAREZ, R.P.P Estudo Experimental e Teórico da Qualidade de Água da Drenagem Urbana com Base em Hidroecologia. Dissertação (Mestrado) - Universidade de São Paulo, Escola de Engenharia de São Carlos, São Carlos, 2010. 139p.

ALVES, E. M. Medidas não-estruturais na prevenção de enchentes em bacias urbanas: cenários para a bacia do Gregório, São Carlos - SP. Dissertação (Mestrado) - Universidade de São Paulo, Escola de Engenharia de São Carlos, São Carlos, 2005. 149p.

ALVES FILHO, A. P.; RIBEIRO, H. A Percepção do Caos Urbano, as Enchentes e as suas Repercussões nas Políticas Públicas da região Metropolitana de São Paulo. Revista Saúde e Sociedade, v.15, n.3, p.145-161, 2006

ARAÚJO, P. R.; TUCCI, C. E. M.; GOLDENFUM, J. A. Avaliação da eficiência dos pavimentos permeáveis na redução de escoamento superficial. Revista Brasileira de Recursos Hídricos, v.5, p.21-29, 2000.

ATCHINSON, P.E.D. Greening Stormwater Infrastructure: Integrating Low-Impact Development with Traditional Methods in Washington State. Low Impact Development for Urban Ecosystem and Habitat Protection. p.1-10. 2008. 
AUTIXIER, L.; MAILHOT, A.; BOLDUC, S.; MADOUX-HUMERY, A.; GALARNEAU, M.; PREVOST, M.; DORNER, S. Evaluating rain gardens as a method to reduce the impact of sewer overflows in sources of drinking water. Science of the Total Environment, v.499, p.238247, 2014.

BACH, P.M.; DELETIC, A.; URICH, C.; SITZENFREI, R.; KLEIDORFER, M; MCCARTHY, D.T. Modelling Interactions Between Lot- Scale Decentralised Water Infrastructure and Urban Form - a Case Study on Infiltration Systems. Water Resources Management, v.27, n.14, p.4845-4863, 2013

BARBASSA, A.P. Simulação do efeito da urbanização sobre a drenagem pluvial na cidade de São Carlos, SP. Tese (Doutorado) - Universidade de São Paulo, Escola de Engenharia de São Carlos, São Carlos, 1991. 327p.

BARBOSA, A.E., FERNANDES J.N., DAVID L.M. Key issues for sustainable urban stormwater management. Water Research v.46, p.6787-6798, 2012.

BARRET, M.E. Performance Comparison of Structural Stormwater Best Management Practices. Water Environment Research, v.77, n.1, p.78-86, 2005.

BARROS, R.M. Previsão de Enchentes para o Plano Diretor de Drenagem Urbana de São Carlos (PDDUSC) na Bacia Escola do Córrego do Gregório. Tese (Doutorado) Universidade de São Paulo, Escola de Engenharia de São Carlos, São Carlos, 2005. 279p.

BARTOLOMEU, D. Análise da vulnerabilidade dos recursos hídricos na região urna de São Carlos (SP) por vazamento em postos de combustíveis, utilizando o método GOD e avaliação dos condicionantes geotécnicos. Dissertação (Mestrado) - Universidade de São Paulo, Escola de Engenharia de São Carlos, p.173. São Carlos, 2012.

BAPTISTA, M.; NASCIMENTO, N.O.; BARRAUD, S. Técnicas compensatórias em Drenagem Urbana. Porto Alegre: ABRH, 2005.

BERGMAN, N., HEDEGAARD, M.R., FJENDBO, M., BINNING, P.P., MARK, O.; MIKKELSEN, P.S. Evaluation of two stormwater infiltration trenches in central Copenhagen after 15 years of operation. NOVATECH, 2010.

BERNDTSSON, J.C. Green roof performance towards management of runoff water quantity and quality: A review. Ecological Engineering, v.36, p.351-360, 2010. NOVATECH, Lyon, 2010.

BOLDRINI, R.S. Avaliação de cenários de inundações urbanas a partir de medidas não estruturais de controle: trecho da bacia do Córrego do Gregório, São Carlos - SP. Dissertação (Mestrado) - Universidade de São Paulo, Escola de Engenharia de São Carlos, São Carlos, 2005. 202p.

BOOTH D.B.; LEAVITT J. Field evaluation of permeable pavement systems for improved storm water management. American Planning Association Journal, .v.65. 1999

BRANDER, K.; OWEN, K.; POTTER, K. Modeled Impacts of Development Type on Runoff Volume and Infiltration Performance. Journal of the American Water Resources Association, v.40, n.4, p.961-969, 2004.

BRATTEBO, B.O., BOOTH, D.B. Long-term storm water quantity and quality performance of permeable pavement systems. Water Research, v.37, n.26, 2003. 
BREDA, A. Avaliação de melhorias para um sistema de previsão hidrológica horária. Dissertação (Mestrado) - Universidade Federal do Paraná, 2008.

BURNS, M.J.; FLETCHER, T.D.; WALSH, C.J.; LADSON, A.R.; HATT, B.E. Hydrologic shortcomings of conventional urban stormwater management and opportunities for reform. Landscape and Urban Planning, v.105, n.3, p.230-240, 2012.

BURSZTA-ADAMIAK, E.; MROWIEC, M. Modelling of green roofs' hydrologic performance using EPA's SWMM. Water Science \& Technology, v.68, n.1, 2013.

BUTLER, D.; DAVIES, J.W. Urban Drainage. London: Spon Press, ed.3, 2010.

CANHOLI, A.P. Drenagem urbana e controle de enchentes. São Paulo: Oficina de Textos, 2005. 302p.

CARTER, T.; JACKSON, R.J. Vegetated roofs for stormwater management at multiple spatial scales. Landscape and Urban Planning, v.80, p84-94, 2007.

CARTER, T.L.; RASMUSSEN, T.C. Hydrologic Behavior of Vegetated Roofs. Journal of the American Water Resources Association. N.42, v.5, p.1261-1274, 2006.

CHAHAR, B.R.; GRAILLOT, D.; GAUR, S. Storm-Water Management through Infiltration Trenches. Technical release: Journal of Irrigation and Drainage Engineering, p. 274-281, 2012.

CHOW, M. F.; YUSOP, Z.; TORIMAN, M. E. Modelling runoff quantity and quality in tropical urban catchments using Storm Water Management Model. International Journal of Environmental Science and Technology, v.9, n.4, p.737-748, 2012.

COUPE, S.J., SMITH H.G., NEWMAN A.P., PUEHMEIER T. Biodegradation and microbial diversity within permeable pavements. European Journal of Protistology, v.39, n.4, 2003.

COUGHLIN, J.P.; CAMPBELL, C.D.; MAYS, D.C. Infiltration and Clogging by Sand and Clay in a Pervious Concrete Pavement System. Journal of Hydrologic Engineering, v.17, p.6873, 2012.

CRUZ, M.A.S.; TUCCI, C.E.M. Avaliação dos cenários de planejamento da drenagem urbana. Revista Brasileira de Recursos Hídricos, v.13, n.3, p.59-71, 2008.

DAAE - Departamento de Águas e Energia Elétrica São Paulo. Plano Estadual de Recursos Hídricos: 2004 / 2007 Resumo. São Paulo: Conselho Estadual de Recursos Hídricos, 2006.

DAMODARAM, C.; GIACOMONI, M.H.; KHEDUN, C.P., HOLMES, H.; RYAN, A.; SAOUR, W.; ZECHMAN, E.M. Simulation of Combined Best Management Practices and Low Impact Development for Sustainable Stormwater Management. Journal of the American Water Resources Association, v.46, n.5, p.907-918, 2010.

DAVIS, A.P. Field performance of bioretention: hydrology impacts. Journal of Environment Engineering, n.13, n.2, 2008.

DAVIS, A.P.; WILLIAM, F.H.; TRAVER, R.G.; CLAR, M. Bioretention Technology: Overview of Current Practice and Future Needs. Jounal of Enivormental Engineering, v.135, p.109-111, 2009. 
DEBUSK, K.M; WYNN, T.M. Storm-water bioretention for runoff quality and quantity mitigation. Journal of Environment Engineering, v.137, n.9, 2011.

DECINA, T.G.T. Análise de medidas de controle de inundações a partir da avaliação de cenários de uso e ocupação do solo na bacia hidrográfica do Córrego do Gregório, São Carlos - SP. Dissertação (Mestrado) - Universidade de São Paulo, Escola de Engenharia de São Carlos. São Carlos, 2012.

DELETIC, A.; FLETCHER, T.D. Performance of grass filters used for stormwater treatment A field and modelling study. Journal of Hydrology. v.317, p.261-275, 2006.

DIETZ M. Low impact development practices: a review of current research and recommendations for future directions. Water Air Soil Pollut. v.186, 2007.

DOTTO, C.B. Acumulação e balanço de sedimentos em superfícies asfálticas em área urbana de Santa Maria/RS. Dissertaçao (Mestrado) - Universidade de Santa Maria. Santa Maria, 2006. 126p.

ELLIOTT, A; TROWSDALE, S. A review of models for low impact urban stormwater drainage. Environmental Modelling \& Software, v.22, n.3, p.394-405, 2007.

EMERSON, C.H.; WELTY, C.; TRAVER, R.G. Watershed-Scale Evaluation of a System of Storm Water Detention Basins. Journal of Hydrologic Engineering, v.10, n.3, 2005.

ESLAMI, S.M.R., FAHZELI, H.R., MEHRABAN, A. GIS-based model to evaluate low impact development suitability location. Geospatial World, 2011.

FCTH - FUNDAÇÃO CENTRO TECNOLÓGICO DE HIDRÁULICA. Projeto técnico: Jardins de Chuva. Sem informação de data.

FERGUSSON, B. K. Porous Pavements. Integrative Studies in Water Management and Land Development. Florida: CRC Press, 2005.

FISCHER, D., CHARLES, E.G., AND BAEHR, A.L. Effects of stormwater infiltration on quality of groundwater beneath retention and detention basins. Journal of Environmental Engineer, v.139, n.5, p.464-471, 2003.

FLETCHER T.D.; SHUSTER, W.; HUNT, W.F.; ASHLEY, R.; BUTLER, D.; ARTHUR, S.T.; BARRAUD, S.; DAVIES, A.S.; KRAJEWSKI, J.B.; MIKKELSEN, P.S.; RIVARD, G.; UHL, M. DAGENAIS, D.; VIKLANDER, M. SUDS, LID, BMPs, WSUD and more - The evolution and application of terminology surrounding urban drainage. Urban Water Journal, v.12, n.7, p.525-542. 2015.

GALBETTI, M.V. Comparação dos modelos hidrológicos presentes no SSD ABC6 aplicados a uma bacia urbana. Dissertação (Mestrado) - Universidade de São Paulo, Escola de Engenharia de São Carlos, p.130. São Carlos, 2015.

GASPERI J, GROMAIRE MC, KAFI M, MOILLERON R, CHEBBO G. Contributions of wastewater, runoff and sewer deposit erosion to wet weather pollutant loads in combined sewer systems. Water Research, n. 44, n.10, p.5875-86. 2010.

GHISI, E.; TAVARES, D. D. F.; ROCHA, V. L. Rainwater harvesting in petrol stations in Brasília: Potential for potable water savings and investment feasibility analysis. Resources, Conservation and Recycling, v.54, n.2, p.79-85, 2009 
GILROY, K.; MCCUEN, R. Spatio-Temporal Effects of Low Impact Development Practices. Journal of Hydrology, v.367, p.228-236, 2009.

GNECCO, I.; PALLA, A.; LANZA, L. G.; BARBERA, P. The Role of Green Roofs as a Source/sink of Pollutants in Storm Water Outflows. Water Resources Management, v.27, n.14, p.4715-4730, 2013.

GOLDENFUN, J.A.; TASSI, R.; MELLER, A.; ALLASIA, D.G.; SILVEIRA, A.L. Challenges for the Sustainable Urban Stormwater Management in Developing Countries: From basic education to technical and institutional issues. NOVATECH, Lyon. p.1-8, 2007.

GOONETILLEKEA, A.; THOMASB, E.; SIMON, G.S.; GILBERT, D. Understanding the role of land use in urban stormwater quality management. Journal of Environmental Management., v74, n.1, p.31-42, 2005.

GRACIOSA, M.C.P. Modelo de seguro para riscos hidrológicos com base em simulação hidráulico- hidrológica como ferramenta de gestão do risco de inundações. Dissertação (Mestrado) - Universidade de São Paulo, Escola de Engenharia de São Carlos. São Carlos, 2010.

GUARULHOS. Lei Municipal no6.793 - Dispõe sobre o lançamento, arrecadação e fiscalização do Imposto Sobre a Propriedade Predial e Territorial Urbana - IPTU e dá outras providências. Diário Oficial do Município, SP, 2010.

GUNDERSON, J.; ROSEEN, R.; JANESKI, T.; HOULE, J.; SIMPSON, M. Economical CSO management. Stormwater v.12, 2011.

HAMEL, P.; DALY, E.; FLETCHER, T.D. Source-control stormwater management for mitigating the impacts of urbanisation on baseflow: A review. Journal of Hydrology, v.485, p.201-211, 2013.

HOLZ, J.; TASSI, R. Usando estruturas de drenagem não convencionais em grandes áreas: o caso do loteamento Monte Bello. XVII Simpósio Brasileiro de Recursos Hídricos, p.1-19, 2007.

HONOLULU- City and Count of Honolulu. Storm Water BMP Guide. Hawaii: Department of Planning and Permiting, 2012.

JAMES, W.; ROSSMAN, L. A.; JAMES, W. R. C. User's guide to swmm5. EPA, 2010.

JAMES, M.B.; DYMOND, R.L. Bioretention hydrologic performance in an urban stormwater network. Journal of Hydrologic Engineering, n.17, 2012.

JANG, S.; CHO, M.; YOON, J.; YOON, Y.; KIM, S. Using SWMM as a tool for hydrologic impact assessment. Desalination, v.212, p.344-356, 2007.

JENSEN, C.A.; QUIN, R.J.; DAVIS, T.H. Urban Watershed Management: Using Remote Sensing to Implement Low Impact Development. Conference: Infrastructure Systems and Services: Next Generation Infrastructure Systems for Eco-Cities - INFRA, 2010.

KIRBY, A. SuDS - innovation or a tried and tested practice? Proceedings of the ICEMunicipal Engineer, v.158, n.2, p.115-122, 2005. 
KREBS, G.; KOKKONEN, T.; VALTANEN, M.; SETÄLÄ, H.; KOIVUSALO, H. Spatial resolution considerations for urban hydrological modelling. Journal of Hydrology, v.512, p.482-497, 2014.

LABSID - Laboratório de Sistemas de Suporte a Decisões. ABC - Sistema de Suporte a Decisões para Análise de Ondas de Cheia em Bacias Complexas. Escola Politécnica da Universidade de São Paulo, 2000. < http://www.labsid.eng.br/>

LI, J.; LI, Y.; LI, Y. SWMM-based evaluation of the effect of rain gardens on urbanized areas. Environmental and Earth Science, v.75, n.17, 2016.

LOCATELLI, L; MARK, O.; MIKKELSEN, P.S.; ARNBJERG-NIELSEN, K, WONG, T.; BINNING, P.J. Determining the extent of groundwater interference on the performance of infiltration trenches. Journal of Hydrology, v.529, p.1360-1372, 2015.

LOS ANGELES, City of. Development Best Management Practices Handbook. California: Sanitation Department of Public Works, 2011.

LUCAS, W.C. Design of Integrated Bioinfiltration-Detention Urban Retrofits with Design Storm and Continuous Simulation Methods. Journal of Hydrologic Engineering, v.15, n.6, p.486498, 2010.

LUCKE, T.; MOHAMED, A.K.M.; TINDALE, N. Pollutant Removal and Hydraulic Reduction Performance of Field Grassed Swales during Runoff Simulation Experiments. Water, v.6, p.1887-1904, 2014.

MAIDMENT, D.R. GIS and hydrology modeling. In: GOODCHILD, M.F.; PARKS, B.O.; STEYAERT, L.T. Environmental Modeling with GIS. New York: Oxford University Press, p.147167, 1993.

MAILHOT A.; BOLDUC S.; DUCHESNE S.; VILLENEUVE JP. Adaptation aux changements climatiques (cc) en matière de drainage urbain au québec: revue de littérature et analyse critique des mesures de contrôle à la source. Québec, Canada, 2008. 55p.

MARTIN, C.; RUPERD Y.; REGRET M. Urban stormwater drainage management: The development of a multicriteria decision aid approach for best management practices. European Journal of Operational Research, v.181, p.338-349. 2007.

MARTINS, L.G.B. Determinação de parâmetros hidrológicos por técnicas de sensoriamento remoto em macrodrenagem urbana. Dissertação (Mestrado) - Universidade de São Paulo, Escola de Engenharia de São Carlos, p.113. São Carlos, 2012.

MENDIONDO, E.M. Incentivos Ambientais - "IPTU Hidrológico". Mini-curso apresentado no VII ENAU. São Paulo, 2007.

MENTENS, J; RAES, D.; HERMY, M. Green roofs as a tool for solving the rainwater runoff problem in the urbanized 21st century? Landscape and Urban Planning v.77, p.217-226, 2006.

MESSAGE, L.B. Classificação do uso e ocupação na bacia hidrográfica do córrego do Monjolinho, São Carlos-SP, utilizando SIG. Trabalho de Conclusão de Curso Universidade de São Paulo, Escola de Engenharia de São Carlos, 2014.

MIGUEZ, M.G. M. Modelo Matemático de Células de Escoamento para Bacias Urbanas. Tese de Doutorado - COPPE/UFRJ, Rio de Janeiro, 2001. 
MIGUEZ, M.G.; MASCARENHAS, F.C.B.; MAGALHÃES, L.P.C.; D'ALTERIO, C.F.V. Planning and Design of Urban Flood Control Measures: Assessing Effects Combination. Journal of Urban Planning and Development, v.135, p.100-109, 2009.

MINKE, G. Techos verdes. Planificación, ejecución, consejos prácticos. Uruguai: EcoHabitar, 2005, 86p.

MIRANDA, E.E. Brasil em Relevo. Campinas: Embrapa Monitoramento por Satélite, 2005. Disponível em: <http://www.relevobr.cnpm.embrapa.br>

NASCIMENTO, N.O.; ELLIS, J.B.; BAPTISTA, M.B.; DEUTSCH, J. Using detention basins : operational experience and lessons. Urban Water, v.1, p.113-114, 1999.

OLIVEIRA, R.C. Medidas não estruturais na prevenção e controle de enchentes em áreas urbanas, como subsídios para o planejamento de uso e ocupação do solo: estudo de caso bacia do córrego do Gregório - São Carlos (SP). Dissertaçao (Mestrado) - Universidade de São Paulo, Escola de Engenharia de São Carlos, São Carlos, 1999. 133p.

PALLA, A.; GNECCO, I.; LANZA, L.G. Compared performance of a conceptual and a mechanistic hydrologic models of a green roof. Hydrologycal Processes, v.26, p.73-84, 2012.

PEREZ-PEDINI, C.; LIMBRUNNER, J.F.; VOGEL, R.M. Optimal Location of Infiltration-Based Best Management. Journal of Water Resources Planning and Management, v.131. n.6, 2005.

PMSC - Prefeitura Municipal de São Carlos. Plano Diretor de Drenagem Urbana Ambientalmente Sustentável do Município de São Carlos: relatório síntese. v.1 São Carlos: Secretaria Municipal de Obras Públicas, 2011.

POLETO, C.; CHARLESWORTH, S. Sedimentology of Aqueous Systems. Londres: WileyBlackwell, 2010.

POMPÊO, C.A. Drenagem urbana sustentável. Revista Brasileira de Recursos Hídricos, v.5, n.48, p.15-23, 2000.

PORTLAND, The city of. Portland Stormwater Management Manual. Oregon, 2008

PORTO ALEGRE, Decreto Municipal №15.371 Regulamenta o controle da drenagem urbana. Diário Oficial do Município, 2006.

PORTO ALEGRE - Departamento de Esgotos Pluviais (DEP). Plano Diretor de Drenagem Urbana: Manual de Drenagem Urbana. Porto Alegre: DEP, 2005.

PSP - Pudget Sound Partnership. LID Technical Guidance Manual for Puget Sound. Washington: Washington State University, 2012

QIN, H.; LI, Z.; FU, G. The effects of low impact development on urban flooding under different rainfall characteristics. Journal of Environmental Management, v.129, p.1-9, 2013.

RIBEIRO, C.A.G.; MENDIONDO, E.M. Sinaleira ambiental como estratégia de gestão de risco de inundação - estudo de caso na população da micro-bacia do Gregório, São Carlos, SP (Brasil). Internacionales sobre Gestión Del Riesgo de Inundaciones y Deslizamientos de Laderas. São Carlos, 2007. 


\section{ROSSMAN, L. Storm Water Management Model User'S Manual. 2010.}

SAMPLE, D.; HEANEY, J.Integrated Management of Irrigation and Urban Storm-Water Infiltration. Journal of Water Resources Planning and Management v.132, n.5, p.362-373, 2006.

SARTORI, A.; LOMBARDI NETO, F.; GENOVEZ, A. M. Classificação hidrológica de solos brasileiros para a estimativa da chuva excedente com o método do serviço de conservação do solo dos Estados Unidos parte 1: Classificação. Revista Brasileira de Recursos Hídricos, v.10, n.4, p.5-18. 2005.

SÃO PAULO. Lei municipal №13.276. Torna obrigatória a execução de reservatório para as águas coletadas por coberturas e pavimentos nos lotes, edificados ou não, que tenham área impermeabilizada superior a 500m². Diário Oficial do Município, 2002.

SÃO PAULO - Secretaria Municipal de Desenvolvimento Urbano (SMDU). Manual de drenagem e manejo de águas pluviais: aspectos tecnológicos; diretrizes para projetos. São Paulo: SMDU, 2012.

SCHOLZ, M.; GRABOWIECKI, P. Review of permeable pavement systems. Building and Environment, v.42, p.3830-3836, 2007.

SHIN, D.S.; PARK, J.B.; KANG, D.K.; JO, D.J. An Analysis of Runoff Mitigation Effect Using SWMM-LID Model for Frequently Inundated Basin. Journal of KOSHAM, v.13, n.4, p.303309, 2013.

SHINMA, T.A. Calibração multiobjetivo do SWMM aplicada à transformação chuva-vazão. Dissertação (Mestrado) - Universidade de São Paulo, Escola de Engenharia de São Carlos. São Carlos, 2011.

SHINMA, T.A. Avaliação de incertezas na calibração automática do modelo SWMM. Tese (Doutorado) - Universidade de São Paulo, Escola de Engenharia de São Carlos. São Carlos, 2015.

SHS - CONSULTORIA E PROJETOS DE ENGENHARIA LTDA. Plano Diretor da macrodrenagem da cidade de São Carlos - Relatório de andamento n.4 - Analise Hidráulica. SHS - Consultoria e Projetos de Engenharia Ltda., São Carlos-SP, 1993.

SHS - CONSULTORIA E PROJETOS DE ENGENHARIA LTDA. Projeto hidráulico executivo das obras de complementação da galeria de águas pluviais do córrego do gregório São Carlos - SP. 1999.

SILVÉRIO, E..C.; URBINATTI, P.R. Presença de mosquitos (Diptera:Culicidae) em piscinões na zona leste de São Paulo. Revista da Sociedade Brasileira de Medicina Tropical, v.44, n.4, p.504-507, 2011.

SIMMONS, M.T., GARDINER, B., WINDHAGER, S., TINSLEY, J., Green roofs are not created equal: the hydrologic and thermal performance of six different extensive green roofs and reflective and non-reflective roofs in a sub-tropical climate. Urban Ecosystems, n.11, p.339$348,2008$.

SOARES, S.R.A.; PARKINSON, J.; BENARDES, R.S. Analysis of scenarios for wastewater and urban drainage systems in Brazil based on an integrated modeling approach. Water Science \& Technology. v.52, n.9, pp 53-60. 2005. 
STAGGE, J.H.; DAVIS, A.P. Water Quality Benefits of Grass Swales in Managing Highway Runoff. WEFTEC, 2006.

STAGGE, J.H.; DAVIS, A.P.; JAMIL, E.; KIM, H. Performance of grass swales for improving water quality from highway runoff. Water Research. v.46, p.6731-6742, 2012.

SUGG, Z.P.; FINKE, T.; GOODRICH, D.C.; MORAN, M.S.; YOOL, S.R. Mapping Impervious Surfaces Using Object-oriented Classification in a Semiarid Urban Region. Photogrammetric Engineering \& Remote Sensing, v.80, n.4, p.343-352, 2014.

TASSI, R.; VILLANUEVA, A.O.N. Análise do Impacto dos Microrreservatórios de Lote nos Custos de Uma Rede de Drenagem Urbana. Revista Brasileira de Recursos Hídricos Volume, v.9 n.3 p. 89-98, 2004.

TIKKANEN, H. Hydrological modeling of a large urban catchment using a stormwater management model (SWMM). Dissertação (Mestrado) - Universidade de Aalto. Aalto, 2013.

TOMINAGA, E.N.S. Urbanização e cheias: medidas de controle na fonte. Dissertação (Mestrado) - Universidade de São Paulo, Escola Politécnica. São Paulo, 2013. 128p.

TUCCI, C.E.M.; ORDONEZ, J.S.; SIMÕES, L.M. Modelo Matemático Precipitação-Vazão IPH II: Alguns Resultados. IV Simpósio Brasileiro de Recursos Hídricos. ABRH, Anais, Fortaleza, 1981.

UDFCD - Urban Drainage and Flood Control District. Urban Storm Drainage Criteria Manual Volume 3: Best Management Practices. Colorado: UDFCD, 2010.

URRUTIAGUER, M.; EDWARDS, P.; CHANDLER, C. The Evolution of a WSUD Capacity Building Program: The Role of Implementation Targets. NOVATECH, p. 1-10, 2010.

URS, AUTRALIA PDY LTD. WSUD Measures and Aplications. Austrália: URS, 2004.

VANWOERT, N.D.; ROWE, D.B.; ANDRESEN, J.A.; RUGH, C.L.; FERNANDEZ, R.T; XIAO, L. Green roof stormwater retention: effects of roof surface, slope, and media depth. Journal of Environmental Quality, v.34, n.3, 2005. p.1036-1044. 2005.

VILLARREAL, E.L., BENGTSSON, L. Response of a sedum green-roof to individual rain events. Ecological Engineering, n.25, p.1-7, 2005.

WANG, K.; ALTUNKAYNAK, A. Comparative Case Study of Rainfall-Runoff Modeling between SWMM and Fuzzy Logic Approach. Journal of Hydrologic Engineering, v.17, n.2, p.283291, 2012.

WALSH, C.J.; FLETCHER, T.D.; BURNS, M. J. Urban stormwater runoff: a new class of environmental flow problem. PloS one, v.7, n.9, 2012.

WASHINGTON, State of. Eastern Washington LID Guidance: Guide manual. Washington: Department of ecology, 2013.

WILLIAMS, E.S.;WISE, W.R. Hydrologic Impacts of Alternative Approaches to Strom Water Management and Land Development. Journal of the American Water Resources Association, v.42, n.2, p.443-445, 2006. 
WOODS-BALLARD, B.; KELLAGHER, R.; MARTIN, P.; JEFFERIES, C.; BRAY, R.; SHAFFER, P. The SuDS manual. London: CIRIA, 2007.

WRIGHT, L.T.; HEANEY, J.P. Design of distributed stormwater control and reuse systems. Storm Collection Systems Design Handbook. Nova lorque: McGraw-Hill, 2001. 166p.

WRIGHT, T.J; LIU, Y.; CARROLL, N.J.; AHIABLAME, L.M.; ENGEL, B.A. Retrofitting LID Practices into Existing Neighborhoods: Is It Worth It? Environmental Management, n.57, p.856-867, 2016.

XIAO, Q., MCPHERSON, E.; SIMPSON, J.; USTIN, S. Hydrologic Processes at the Urban Residential Scale. Hydrologic Processes, v.21, p.2174-2188, 2007.

ZHANG, G.; HAMLETT, J. M.; REED, P.; TANG, Y. Multi-Objective Optimization of Low Impact Development Designs in an Urbanizing Watershed. Journal of Optimization, v.2, p.95-108, 2013.

ZHEN, X.J.; YU, S.Y; LIN, J. Optimal Location and Sizing of Stormwater Basins at Watershed Scale. Journal of Water Resources Planning and Management, v.130, n.4, 2004. 


\section{APÊNDICE A - MAPAS DE ADEQUABILIDADE À IMPLANTAÇÃO DE DIFERENTES TÉCNICAS COMPENSATÓRIAS}




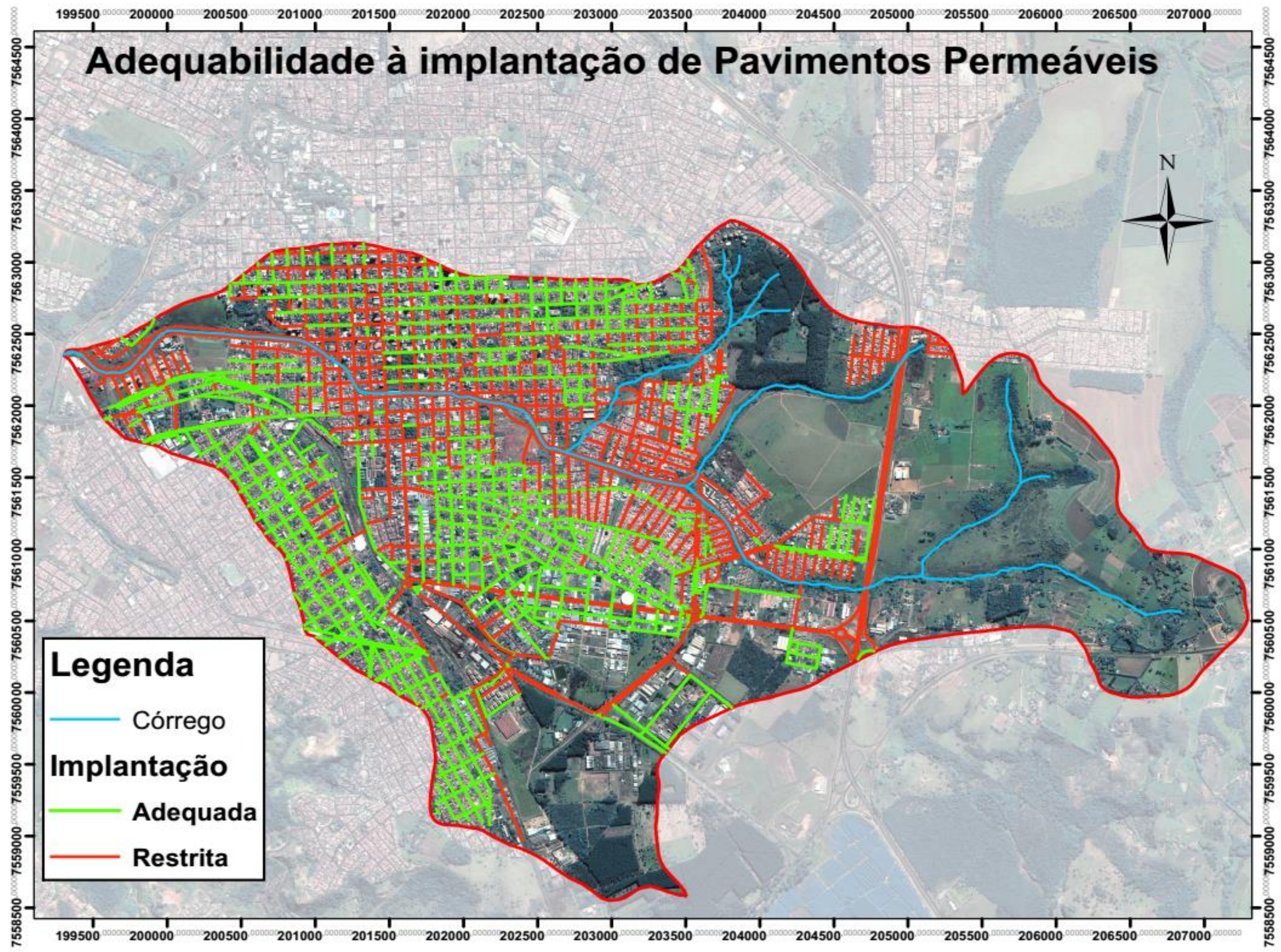




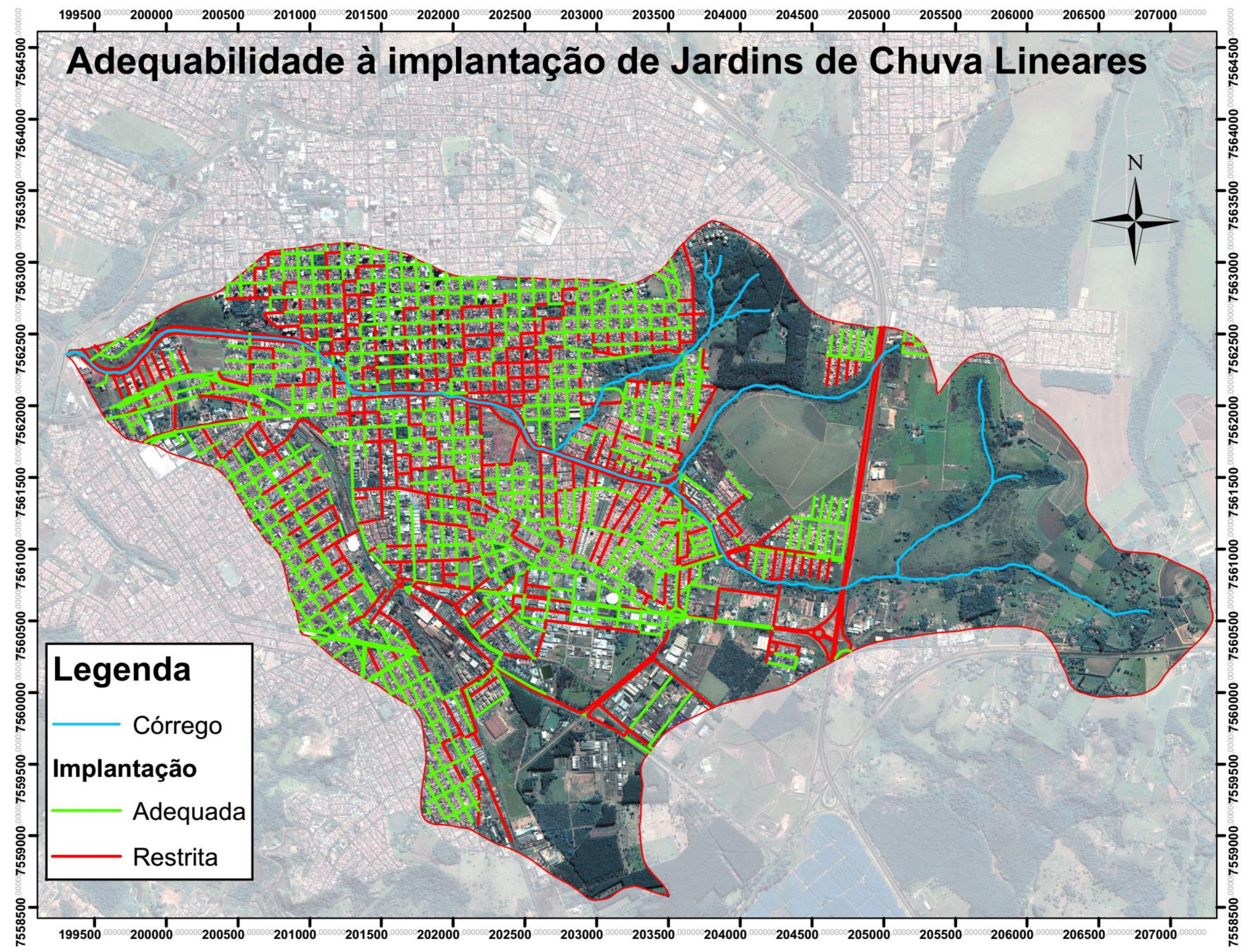




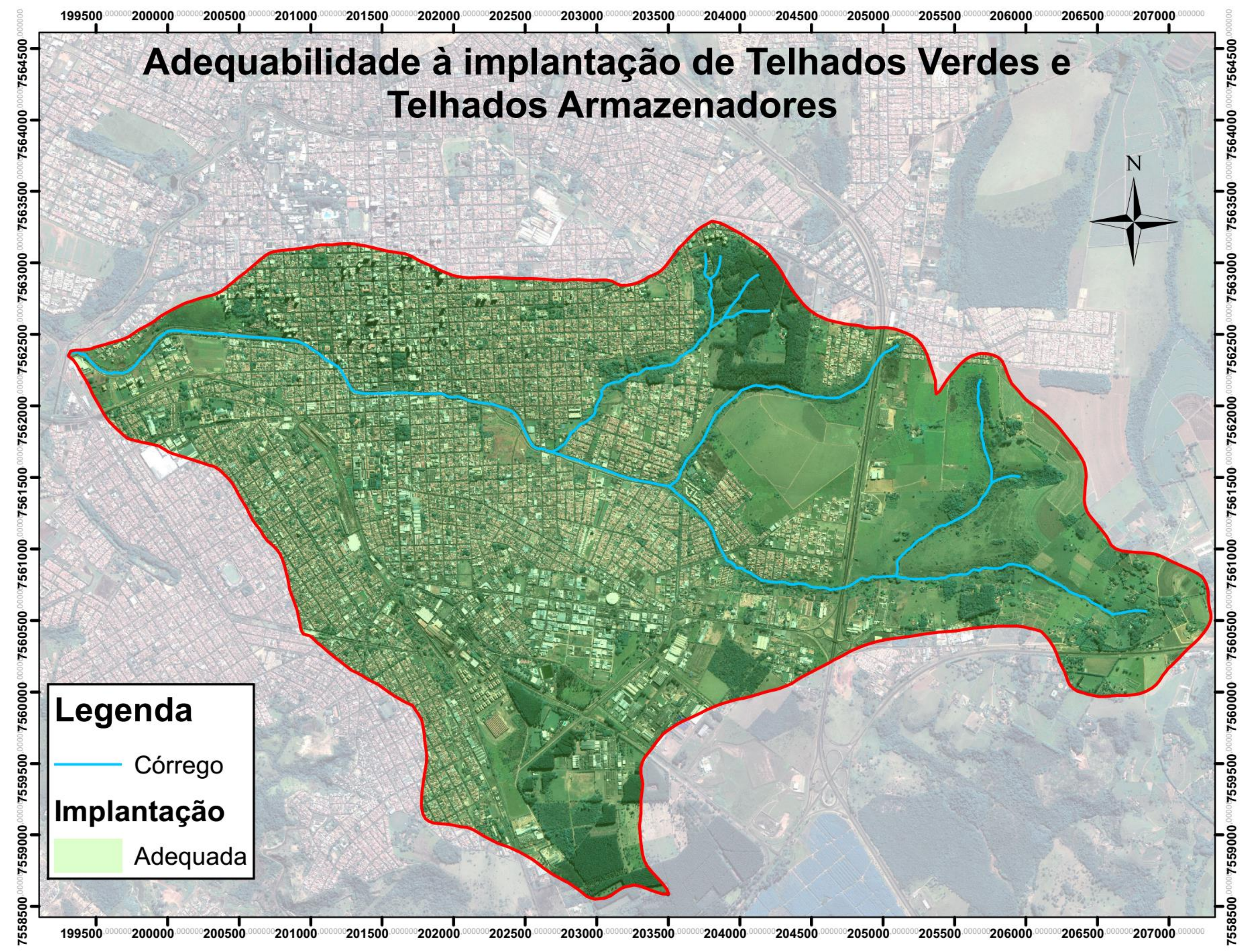




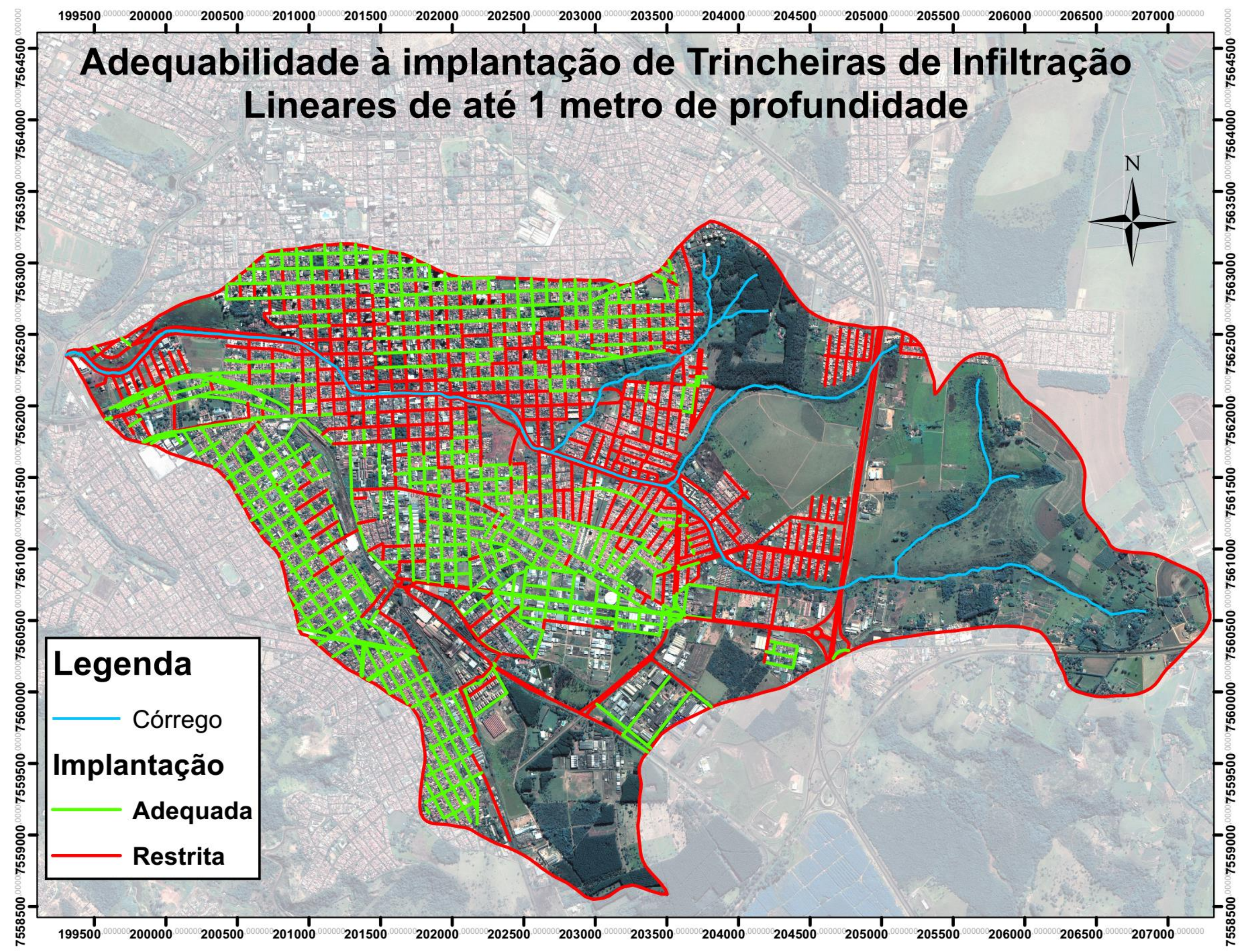




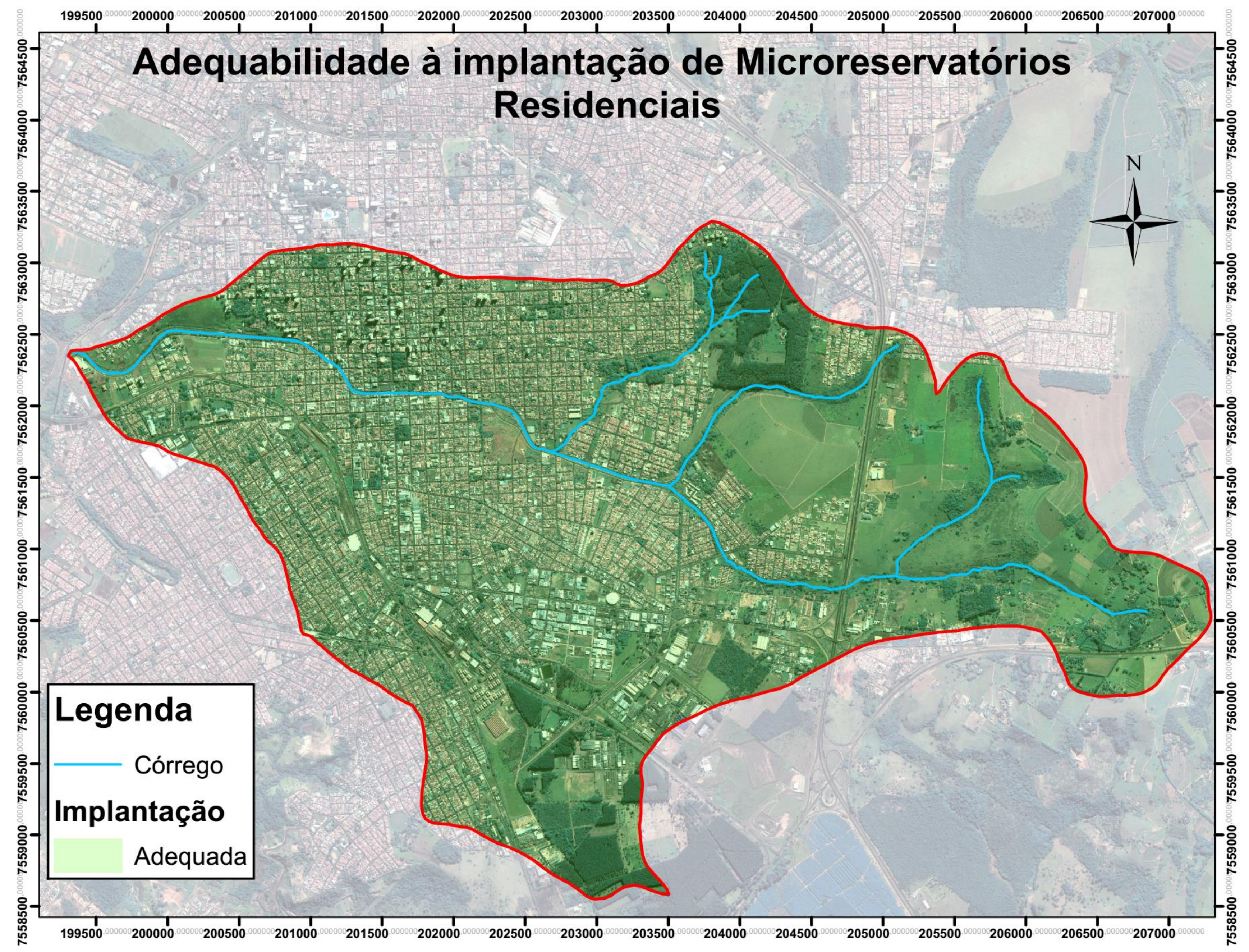




\section{APÊNDICE B - HIDROGRAMAS PARA OS CENÁRIOS HIPOTÉTICOS}
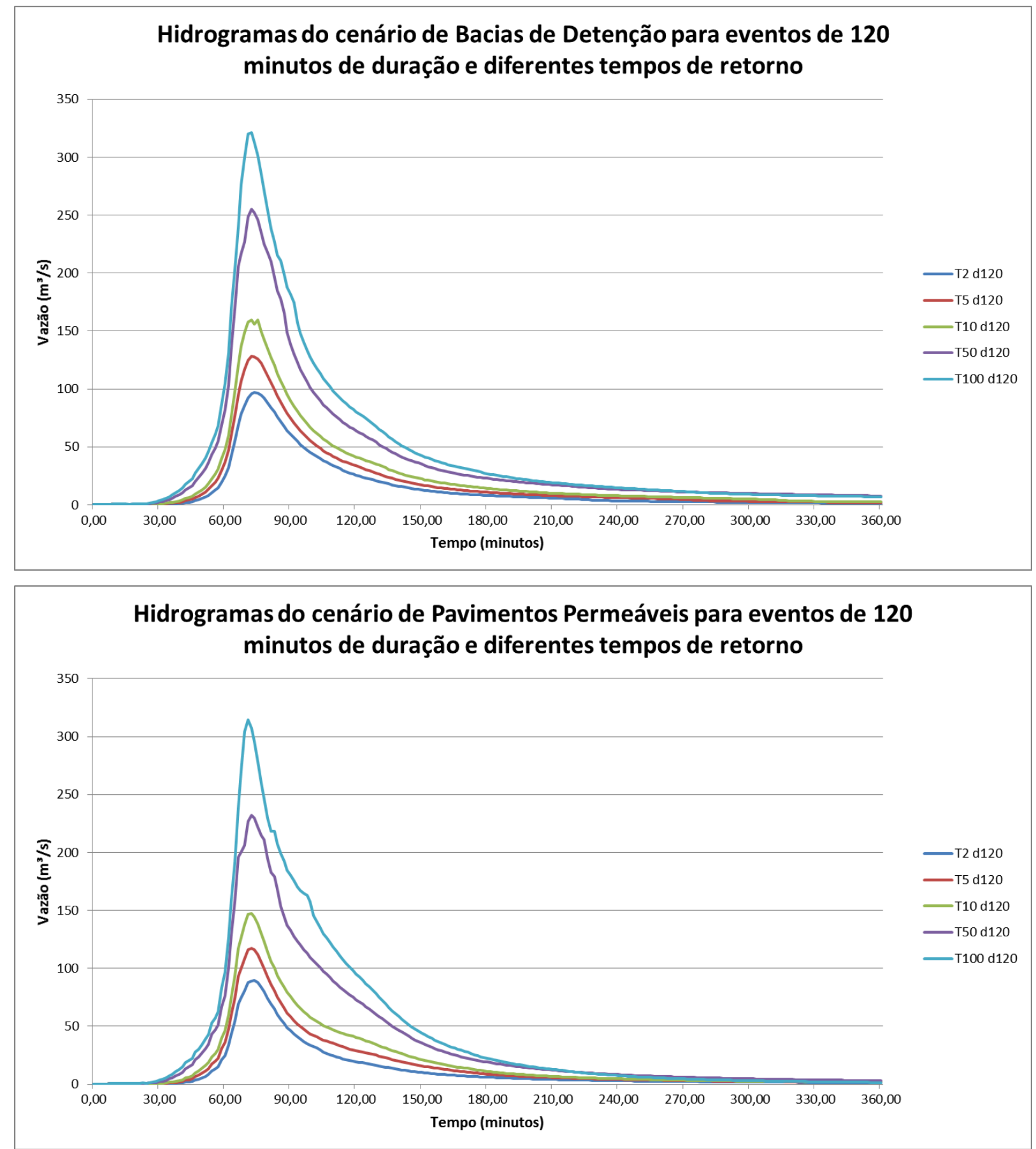

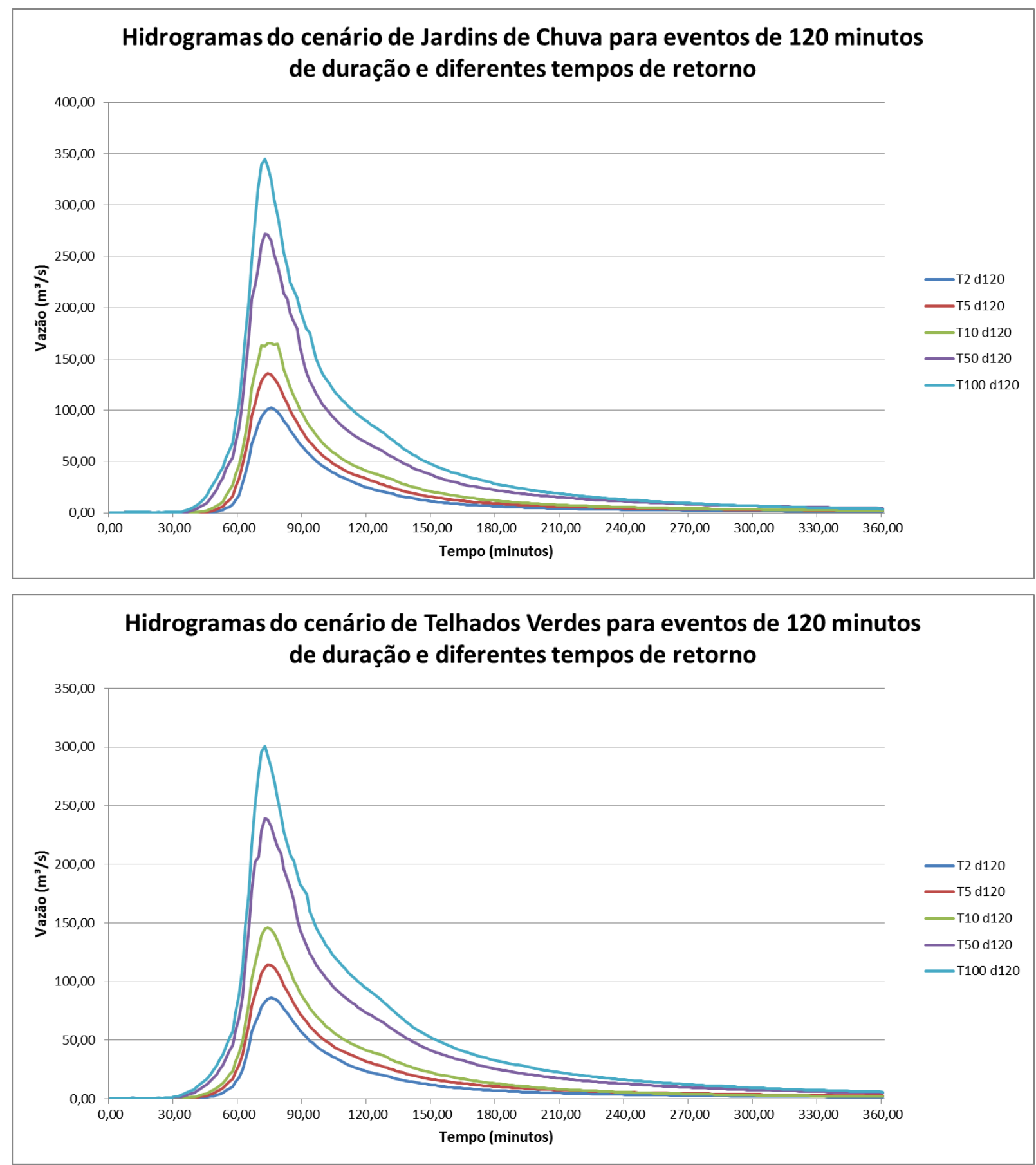

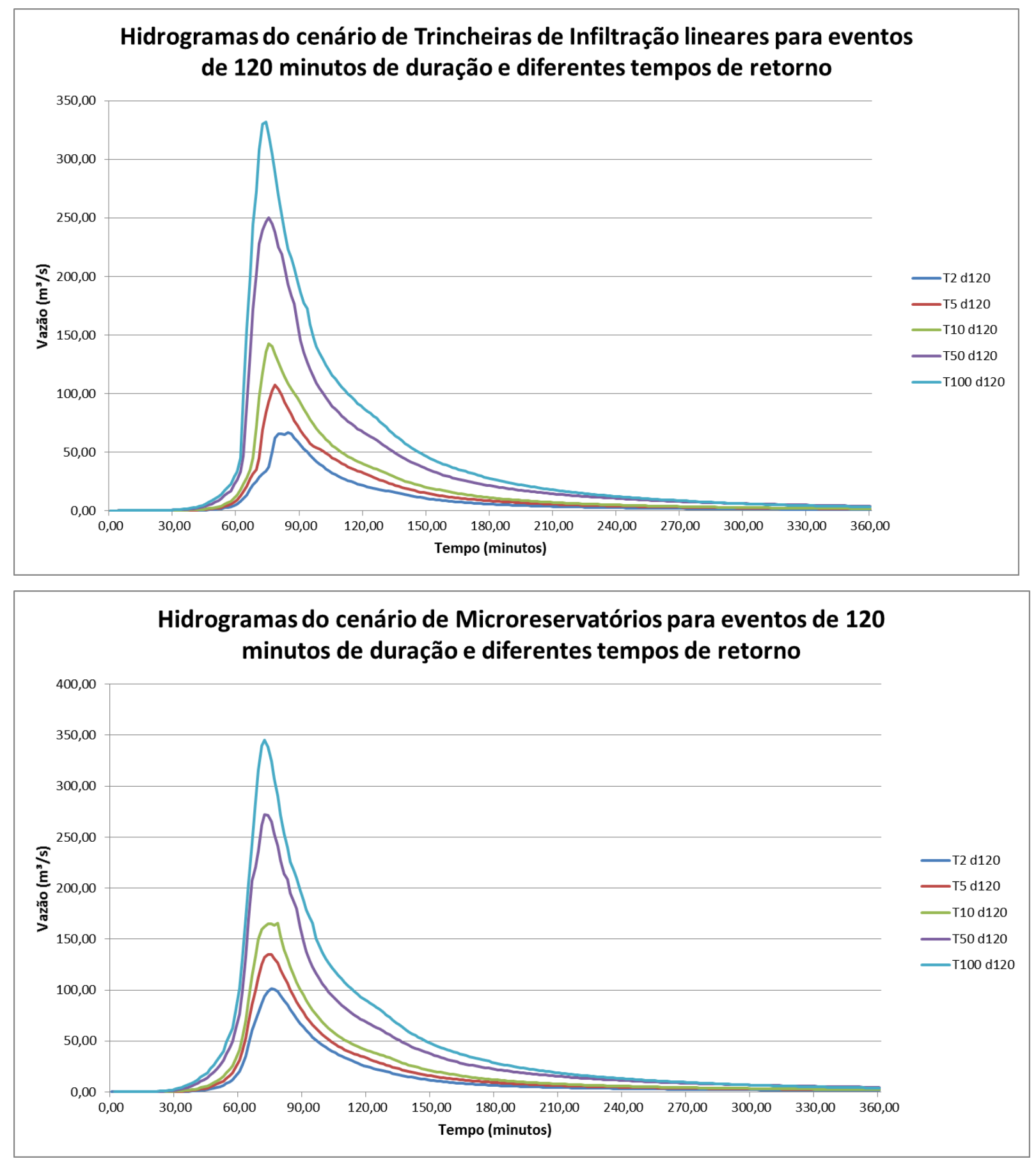


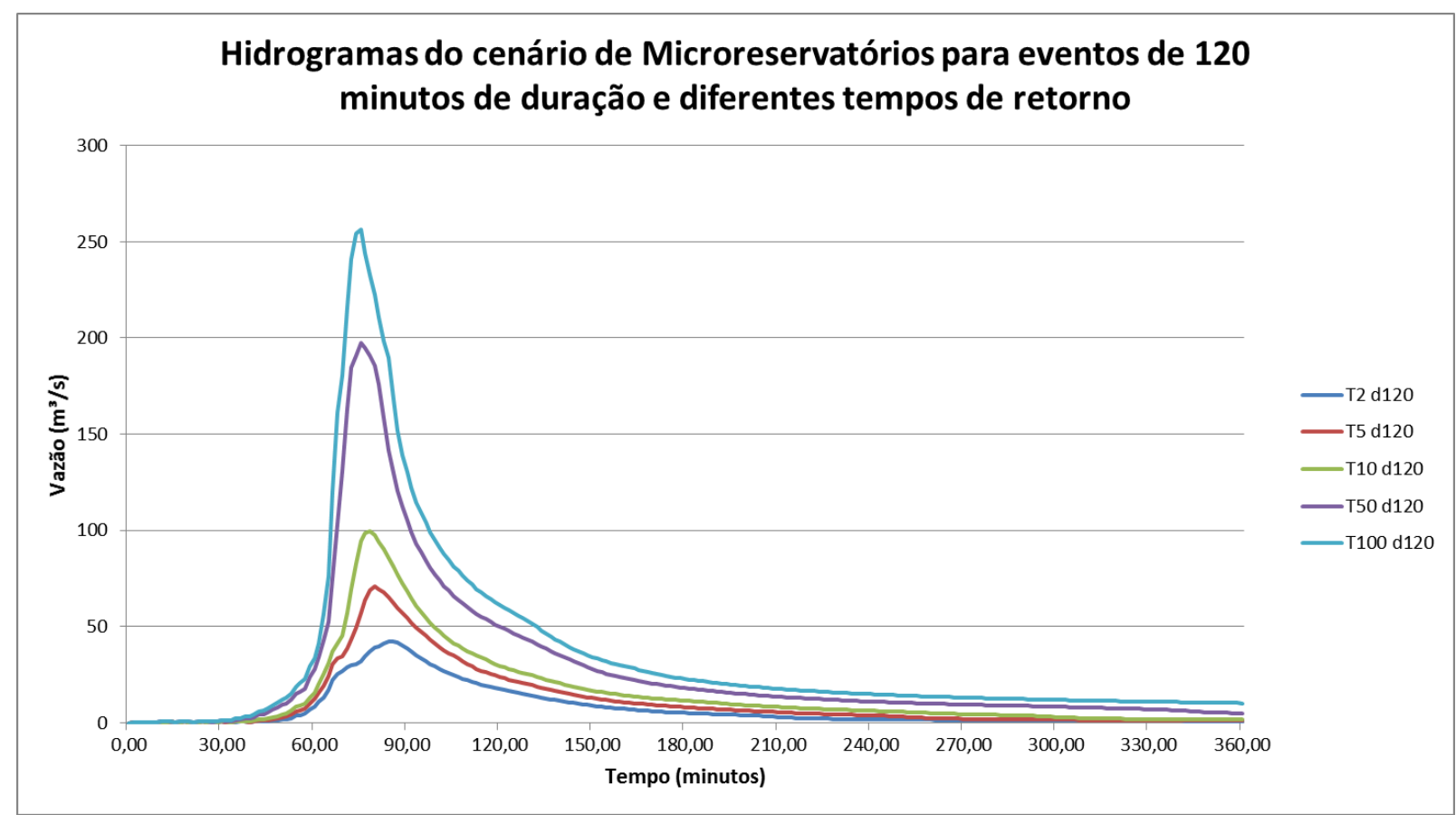




\section{ANEXO 1}

NOTICIAS - FOTOS - VIDEOS - INTERATIVO - CLASSIFICADOS - EMPREGOS FALE CONOSCO COLUNISTAS

SĀOGARLOS

equaracombios

国 Qua, 13 de Janeiro de 2016

o que voce procura?

CIDADE

15/03/2010 - 08h30 | Atualizado em 15/03/2010 - 08h30

Redação São Carlos Agora

\section{Chuva forte causa vários pontos de alagamento na cidade}

A chuva forte que atingiu a região na tarde e noite deste domingo (14) provocou vários pontos de alagamento na cidade. OSão Carlos Agoraesteve em alguns destes locais conferindo de perto a situação

O ponto mais critico foi a rotatória do Cristo, perto do shopping Iguatemi. Somente veículos pesados como caminhões e ônibus conseguiam transitar pelo local. Uma motocicleta tentou vencer a água, mas acabou parando.

O trânsito foi desviado para a região do Santa Mônica. Motoristas que seguiram no sentido shopping pela Avenida Francisco Pereira Lopes precisaram retornar na contra-mão. Vários veículos sofreram pane mecânica e pararam no meio do caminho.

Outro ponto afetado foi a Avenida Comendador Alfredo Maffei no local conhecido como rotatória da Educativa. Um veiculo foi invadido pela água. Neste trecho não é comum haver alagamentos.

A região da baixada do mercado também sofreu com a inundação. Havia muita lama e lixo espalhado pelas ruas. A água não chegou a invadir as lojas do Centro.

Na Praca Itália. embaixo da linha férrea também sofreu com a forte chuva. O local é frequentemente inundado.

Na Rua Conde do Pinhal, perto da creche Anita Costa. várias casas foram invadidas pela áqua. A

\section{Últimas Notícias}

21 h5 - Polícia

Mulher em surto atira-se em frente a veículos na Washington Luis

\section{$19 \mathrm{~h} 48$ - Cidade}

Comitê de combate à Dengue define estratégias de ação

17h39- Cidade

Freire solicita audiência pública para discutir ações de combate à dengue

17 h20 - Região

Assistência Social de Ibaté presta relevantes serviços à população

17h06 - Brasil

Alckmin sanciona Lei que institui Diária Especial da Polícia Civil

15 h49 - Brasil

Emissão de TED não terá mais limite mínimo, 


\section{SÁOCARILS \\ extracentios}

\section{NOTICIAS - FOTOS - VÍDEOS - INTERATIVO - CLASSIFICADOS - EMPREGOS}

Qui, 02 de Junho de 2016

3.568 seguidores

\section{CIDADE}

\section{Chuva forte provoca estragos em São Carlos; veja o vídeo}

Durante aproximadamente uma hora, São Carlos foi atingida por uma forte chuva na tarde desta segunda-feira, 23. Segundo a Defesa Civil choveu aproximadamente 58 milimetros.

Foram registrados alagamento em diversos pontos da cidade, mas sem registro de feridos.

Segundo informações coletadas pelo São Carlos Agora, a rotatória do Cristo, região do Shopping, ficou alagada e muitos motoristas que seguiam, pela avenida Trabalhador São-carlense voltaram pela contramão.

Na região do kartódromo foram registrados pontos de alagamentos e um posto de combustiveis foi atingido. Na reqião do Mercado Municipal. na região central. a situacão era mais complicada. $\mathrm{O}$ volume de água foi intenso e diversos estabelecimentos foram atingidos. Comerciantes calculam os prejuizos. Carros foram arrastados pela forte correnteza

\section{NOS BAIRROS}

A periferia de São Carlos também foi afetada. Há pontos de alagamento no Cidade Aracy e no $\mathrm{CDHU}$ da Vila Isabel. Próximo a UPA do Jardim Santa Felícia veículos ficaram parados devido a grande quantidade de água.

O SCA apurou também que na avenida Francisco Pereira Lopes, próximo a um restaurante, o córrego Monjolinho transbordou e pessoas ficaram presas em seus veículos e o Corpo de Bombeiros foi ao local para realizar o resgate.

Próximo a escola Educativa, região do Conjunto Castelo Branco, foi registrado ponto de alagamento. 


\section{ANEXO 2}

Baixada do Mercado: tubulação para concluir obra chegaram nesta sexta

Prefeitura Municipal de São Carios

30 de Agosto de 2010

A Prefeitura de São Carlos está realizando melhorias na calha do córrego do Gregório em frente ao Mercado Municipal, na praça Maria Aparecida Resitano. Com a obra, a calha ficará rebaixada e o córrego será fechado, aumentando a área livre para circulação de pessoas e o espaço para realização de

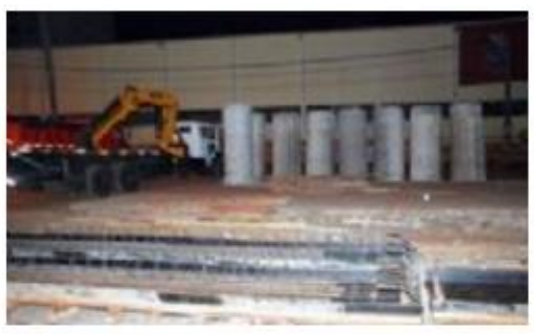
eventos.

Para a execução desta obra, que conta com R\$ 500 mil do Governo Federal, por meio do $P A C$, via BNDES, a Prefeitura já realizou grande parte do cronograma. No entanto, para concluí-la, é preciso executar um trecho de rede de esgoto, que ligará o Mercado Municipal ao Boulevard São Carlos. Os tubos chegaram no início da noite desta sexta-feira (27).

O projeto previu o rebaixamento de 60 centímetros na calha e a readequação da entrada da galeria de águas pluviais que desce pela avenida São Carlos e faz captação da água da chuva da região da praça Itália. As laterais do canal também serão demolidas e refeitas.

Mais uma etapa

Está é a quinta etapa de obras de combate às enchentes que a Prefeitura faz na região do Mercado, o que diminuiu, significativamente, as ocorrências de enchentes. A atual obra faz parte do projeto do Boulevard São Carlos, que prevê a integração de três praças da baixada do Mercado - Maria Apparecida Resitano, Voluntários da Pátria e Pedro de Toledo, por meio de passeios públicos adequados, além de melhorias em cada uma das áreas. $\mathrm{O}$ investimento total é de $\mathrm{R} \$ 3,1$ milhões, também do Governo Federal.

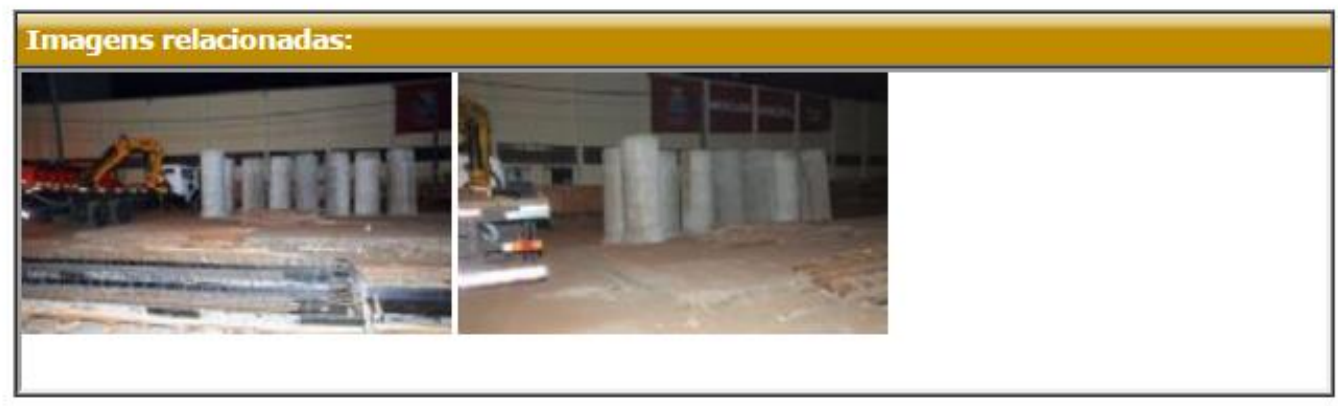

Fonte: São Carlos Agora (2010) 